\title{
2. SITES 501 AND 504: SEDIMENTS AND OCEAN CRUST IN AN AREA OF HIGH HEAT FLOW ON THE SOUTHERN FLANK OF THE COSTA RICA RIFT ${ }^{1}$
}

\author{
Shipboard Scientific Parties of Leg 68 (Site 501), Leg 69, and Leg $70^{2}$
}

\section{LEG 68, SITE 501, HOLE 501}

Date occupied: 8 July 1979

Date departed: 16 July 1979

Time on hole: 8 days

Position: $01^{\circ} 13.63^{\prime} \mathrm{N} ; 83^{\circ} 44.06^{\prime} \mathrm{W}$

Water depth (sea level; corrected m, echo sounding): 3457

Water depth (rig floor; corrected m, echo sounding): 3467

Bottom felt (m, drill pipe): 3466.9

Penetration (m): 337.1

Number of cores: 20

Total length of cored section (m): 147.2

Total core recovered $(\mathrm{m}): 74.53$

${ }^{1}$ Cann, J. R., Langseth, M. G., Honnorez, J., Von Herzen, R. P., White, S. M., et al., Init. Repts. DSDP, 69: Washington (U.S. Govt. Printing Office).

2 J. R. Cann (Co-Chief Scientist, 68/501, 69), Department of Geology, University of Newcastle upon Tyne, Newcastle upon Tyne, United Kingdom; Marcus Langseth (Co-Chief Scientist, 69), Lamont-Doherty Geological Observatory, Columbia University, Palisades, New York; Jose Honnorez (Co-Chief Scientist, 70/504B), Rosenstiel School of Marine and Atmospheric Sciences, University of Miami, Miami, Florida; Richard P. Von Herzen (CoChief Scientist, 70/504B), Woods Hole Oceanographic Institution, Woods Hole, Massachusetts; S. M. White (Co-Chief Scientist, 68/501), Deep Sea Drilling Project, Scripps Institution of Oceanography, La Jolla, California (present address: Pennzoil E \& P Company, Houston, Texas); A. C. Adamson (69), Department of Geology, University of Newcastle upon Tyne, Newcastle upon Tyne, United Kingdom; Roger N. Anderson (68/501, 69), Lamont-Doherty Geological Observatory, Columbia University, Palisades, New York; Timothy Barrett (70/504B), Department of Geology and Mineralogy, Oxford University, Oxford, United Kingdom (present address: Department of Geology, University of Toronto, Toronto, Ontario, Canada); Keir Becker (70/504B), Marine Physical Laboratory, Scripps Institution of Oceanography, La Jolla, California (present address: Deep Sea Drilling Project, Scripps Institution of Oceanography, La Jolla, California); Helmut Beiersdorf (69), Bundesanstalt fuir Geowissenschaften und Rohstoffe, 3 Hannover 51, Federal Republic of Germany; Michael Bender (70/504B), Graduate School of Oceanography, University of Rhode Island, Kingston, Rhode Island; Peter E. Borella (70/504B), Deep Sea Drilling Project, Scripps Institution of Oceanography, La Jolla, California (present address: Saddleback College, Mission Viejo, California); Toshio Furuta (69), Ocean Research Institute, University of Tokyo, Nakano, Tokyo, Japan; HansWolfgang Hubberten (70/504B), Institut für Petrographie und Geochemie der Universität Karlsruhe, Karlsruhe, Federal Republic of Germany; Steven C. Jones (70/540B), Department of Geology, Florida State University, Tallahassee, Florida (present address: Mobil Oil Company, New Orleans, Louisiana); Shun'ichiro Karato (70/504B), Ocean Research Institute, University of Tokyo, Nakano, Tokyo, Japan (present address: Research School of Earth Sciences, The Australian National University, Canberra, Australia); Christine Laverne (70/504B), Laboratoire de Géologie, Faculté des Sciences et Techniques, BPW SFAX, Tunisia; J. R. Lawrence (68/501), Lamont-Doherty Geological Observatory, Columbia University, Palisades, New York; Shaul Levi (70/504B), School of Oceanography, Oregon State University, Corvallis, Oregon; Areg A. Migdisov (70/504B), Vernadsky Institute of Geochemistry and Corvallis, Oregon; Areg A. Migdisov (70/504B), Vernadsky Institute of Geochemistry and
Analytical Chemistry, U.S.S.R. Academy Sciences, Moscow, U.S.S.R.; S. Anthony Moorby (70/504B), Department of Geology, Imperial College, London, United Kingdom; Michael J. Mottl (69), Department of Chemistry, Woods Hole Oceanographic Institution, Woods Hole, Massachusetts; James H. Natland (68/501, 69), Deep Sea Drilling Project, Scripps Institution of Oceanography, La Jolla, California; Vladislav L. Nekhoroshkov (68/501, 69), Institute of Geophysics, Peromayskaya 91, Sverdloysk, U.S.S. R. Yves Noack (69), Laboratoire de MinStrasbourg Cedex, France (present address: Lab Per Nikolai N. Pertsev (68/501, 69), Institute of Geology of Ore Deposits, Petrology, Mineralogy, and Geochemistry, U.S.S.R. Academy of Sciences, Moscow, U.S.S.R.; Vladimir N. Ponomarev (68/501), Institute of Geophysics, Peromayskaya 91, Sverdlovsk, U.S.S.R.; Constance Sancetta (69), Lamont-Doherty Geological Observatory, Columbia University, Palisades, New York; Ed L. Schrader (70/504B), Department of Geology and Geography, University of Alabama, University, Alabama (present address: J. M. Huber Corporation, Macon, Georia); Roy $\mathrm{H}$, Wilkens (69), Department of Ceological Sciences, University of Wash-

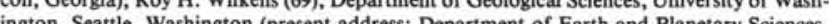
ington, Sealle, Wath. Wik (presen, Massachusetts Institute of Technology, Cambridge, Massachusetts); Mark D. Zoback (68/501),
U.S. Geological Survey, Menlo Park, California (present address: U.S. Geological Survey, Reston, Virginia).

\section{Core recovery (\%): 50.6}

Oldest sediment cored:

Depth sub-bottom (m): 264

Nature: Cherty limestone

Age: No paleontological age (age of magnetic anomaly, 5.9 m.y.)

Measured velocity $(\mathrm{km} / \mathrm{s}): 3.185$

Basement:

Depth sub-bottom (m): 264.1

Meters of basement drilled: 73

Nature: Basalt pillow lavas and massive flow units

Velocity range $(\mathrm{km} / \mathrm{s}): 4.08-5.99$

Principal results: Site 501 is on 5.9 m.y. crust spread from the Costa Rica Rift. Hole 501 served as a pilot hole for re-entry in Hole 504B. The sediment section ( $264 \mathrm{~m}$ thick) was spot cored because continuous piston coring was carried out later in Hole 504. The section consists of pelagic siliceous calcareous (nannofossil) ooze, with some volcanic ash; it becomes more calcareous and indurated with depth. Near the base, chert and cherty limestone bands were recovered. Basalt basement was cored for 73 meters; it consists of alternating massive flow units and rubbly pillow units. The upper petrographic unit is nearly aphyric, the lower unit (below $25 \mathrm{~m}$ ), plagioclase and olivine phyric. Alteration is weak to intense, with clays and carbonate minerals filling veins. The in-hole temperature at 120 meters is $32^{\circ} \mathrm{C}$, consistent with site survey heat flow data. The Lynes packer was used to recover a water sample and attempt a permeability measurement. The borehole televiewer, the downhole magnetometer, and the resistivity tool were successfully deployed. A complete logging program was run.

\section{LEGS 69 AND 70, SITE 504, HOLES 504, 504A, 504B, AND 504C}

Detailed information concerning Site 504 is given in Table 1. Principal results are given below by leg and hole.

Principal results, Leg 69, Hole 504: At Hole 504 sediments were continuously piston cored to a depth of 237 meters, where cherty layers were encountered. The sediment's structures and physical properties were nearly perfectly preserved in the cores. The sedimentary section cored is mainly a siliceous nannofossil ooze of pelagic origin containing a continuous biostratigraphic record from the late Miocene to the Holocene. Discrete volcanic ash layers are few, but disseminated ash and terrigenous windblown clay minerals are present in variable amounts. The sedimentation rate based on the biostratigraphy is $43.5 \mathrm{~m} / \mathrm{m}$.y. and is rather uniform over the whole section.

Lithologically the section can be divided into three units. Unit 1 (late Pliocene to Holocene and 0 to $143.5 \mathrm{~m}$ sub-bottom) consists of an unconsolidated siliceous nannofossil ooze, dark grayish green to olive grayish green in color. A subunit between 65 and 99 meters contains larger amounts of $\mathrm{Mn}$, based on X-ray fluorescence (XRF) analysis. The physical properties of Unit I are extremely uniform. Representative mean values are as follows: sonic velocity, $1.51 \mathrm{~km} / \mathrm{s}$; bulk density, $1.32 \mathrm{~g} / \mathrm{cc}$; porosity, $80 \%$; and thermal conductivity, $0.80 \mathrm{~W} / \mathrm{m}^{\circ} \mathrm{C}$.

Unit II (late Miocene to early Pliocene and 143.5 to $227.2 \mathrm{~m}$ sub-bottom) is a siliceous nannofossil chalk with higher carbonate content (up to $85 \%$ ). The coloration is generally the same but paler. This chalk may represent the first stage in the diagenesis of 
Table 1. Site 504 Summary, Legs 69 and 70

\begin{tabular}{|c|c|c|c|c|c|c|}
\hline Hole: & $\begin{array}{l}504 \\
\text { (Leg 69) }\end{array}$ & $\begin{array}{l}\text { 504A } \\
\text { (Leg 69) }\end{array}$ & $\begin{array}{l}\text { 504B } \\
\text { (Leg 69) }\end{array}$ & $\begin{array}{l}\text { 504B } \\
(\text { Leg 70) }\end{array}$ & $\begin{array}{l}504 \mathrm{~B} \\
\text { (total) }\end{array}$ & $\begin{array}{l}504 \mathrm{C} \\
\text { (Leg 69) }\end{array}$ \\
\hline Date occupied: & $\begin{array}{l}0400, \\
20 \text { Sept. } 1979\end{array}$ & $\begin{array}{l}0000, \\
24 \text { Sept. } 1979\end{array}$ & 7 Oct. 1979 & 4 Dec. 1979 & - & $\begin{array}{l}0856, \\
14 \text { Oct. } 1979\end{array}$ \\
\hline Date departed: & $\begin{array}{l}2330, \\
23 \text { Sept. } 1979\end{array}$ & $\begin{array}{l}0800, \\
29 \text { Sept. } 1979\end{array}$ & 25 Oct. 1979 & 13 Dec. 1979 & - & $\begin{array}{l}0845, \\
15 \text { Oct. } 1979\end{array}$ \\
\hline Time on hole: & 91.5 hours & 128 hours & 436.5 hours & 190.4 hours & 626.9 hours & 24 hours \\
\hline Position: & $\begin{array}{l}01^{\circ} 13.58^{\prime} \mathrm{N} ; \\
83^{\circ} 43.93^{\prime} \mathrm{W}\end{array}$ & $\begin{array}{l}01^{\circ} 13.61^{\prime} \mathrm{N} ; \\
83^{\circ} 43.95^{\prime} \mathrm{W}\end{array}$ & $\begin{array}{l}01^{\circ} 13.63^{\prime} \mathrm{N} ; \\
83^{\circ} 43.81^{\prime} \mathrm{W}\end{array}$ & $\begin{array}{l}01^{\circ} 13.63^{\prime} \mathrm{N} ; \\
83^{\circ} 43.81^{\prime} \mathrm{W}\end{array}$ & $\begin{array}{l}01^{\circ} 13.63^{\prime} \mathrm{N} ; \\
83^{\circ} 43.81^{\prime} \mathrm{W}\end{array}$ & $\begin{array}{l}01^{\circ} 13.64^{\prime} \mathrm{N} ; \\
83^{\circ} 43.89^{\prime} \text { wa }\end{array}$ \\
\hline $\begin{array}{l}\text { Water depth (sea level; corrected } \mathrm{m} \text {, } \\
\text { echo-sounding): }\end{array}$ & 3460 & 3458 & 3460 & 3460 & 3460 & 3460 \\
\hline $\begin{array}{l}\text { Water depth (rig floor; corrected m, } \\
\text { echo-sounding): }\end{array}$ & 3470 & 3468 & 3470 & 3470 & 3470 & 3470 \\
\hline Bottom felt (m, drill pipe): & Not felt & Not felt & 3473.5 & 3473.5 & 3473.5 & Not felt \\
\hline Penetration (m): & 237 & 277 & 489 & 347 & 836 & 220 \\
\hline Number of cores: & 54 & 7 & 29 & 41 & 70 & (b) \\
\hline Total length of cored section (m): & 227 & 70.5 & 227.5 & 347 & 574.50 & 0 \\
\hline Total core recovery $(\mathrm{m})$ : & 176 & 9.01 & 76.66 & 91.5 & 168.2 & 0 \\
\hline Percentage core recovery: & 76 & 20.5 & 33.7 & 26.3 & 29.3 & 0 \\
\hline \multicolumn{7}{|l|}{ Oldest sediment cored: } \\
\hline Depth sub-bottom $(\mathrm{m})$ : & 237 & 264 & 274.5 & 274.5 & 274.5 & - \\
\hline Nature: & $\begin{array}{l}\text { Siliceous lime- } \\
\text { stones and } \\
\text { cherts }\end{array}$ & $\begin{array}{l}\text { Chert and sili- } \\
\text { ceous lime- } \\
\text { stone }\end{array}$ & $\begin{array}{l}\text { Chert and sili- } \\
\text { ceous lime- } \\
\text { stone }\end{array}$ & $\begin{array}{l}\text { Chert and sili- } \\
\text { ceous lime- } \\
\text { stone }\end{array}$ & $\begin{array}{l}\text { Chert and sili- } \\
\text { ceous lime- } \\
\text { stone }\end{array}$ & - \\
\hline Age: & Late Miocene & $5.9 \mathrm{~m} . \mathrm{y} . \mathrm{c}$ & $5.9 \mathrm{~m} . \mathrm{y} . \mathrm{c}$ & $5.9 \mathrm{~m} . \mathrm{y} . \mathrm{c}$ & 5.9 m.y.c & - \\
\hline $\begin{array}{l}\text { Measured velocity }(\mathrm{km} / \mathrm{s}) \text { : } \\
\text { Basement. }\end{array}$ & 4.25 & - & - & - & - & - \\
\hline \multicolumn{7}{|l|}{ Basement: } \\
\hline bottom, $\mathrm{m}$ ): & 237 & 264 & 274.5 & 274.5 & 274.5 & - \\
\hline Meters of basement drilled: & - & 12 & 214 & 347.5 & 561.5 & - \\
\hline Nature: & - & Basalt pillows & $\begin{array}{c}\text { Basalt pillows } \\
\text { and flows }\end{array}$ & $\begin{array}{c}\text { Basalt pillows } \\
\text { and flows }\end{array}$ & $\begin{array}{c}\text { Basalt pillows } \\
\text { and flows }\end{array}$ & - \\
\hline Velocity range $(\mathrm{km} / \mathrm{s})$ : & - & -5.8 & $5.1-6.4$ & $5.1-6.4$ & $5.1-6.4$ & - \\
\hline
\end{tabular}

a Longitude may be in error; only a few satellite navigation fixes received.

b Hole drilled solely for downhole temperature measurements and in situ pore water samples.

c Estimated from magnetic anomalies.

the nannofossil ooze, which is temperature controlled. At Hole 505 , where temperatures are much lower at 140 meters $\left(5^{\circ} \mathrm{C}\right.$, versus $38^{\circ} \mathrm{C}$ at Hole 504), chalky sediments appear only below 210 meters. The mean sonic velocity of the chalks is only slightly higher $(1.54 \mathrm{~km} / \mathrm{s})$, but bulk density and thermal conductivity increase to $1.5 \mathrm{~g} / \mathrm{cc}$ and $1.2 \mathrm{~W} / \mathrm{m}^{\circ} \mathrm{C}$, respectively. Porosity decreases appreciably (to $65 \%$ ).

Unit III begins at 227.2 meters sub-bottom, only 10 meters above the basement. It consists of siliceous limestones and cherty layers. The outlines and colors of worm burrows and halos are preserved in the cherts and give evidence of shrinkage by a factor of 5 .

The entire section of sediment is highly bioturbated: there are innumerable worm burrows, all undisturbed by the piston coring. The extent of the bioturbation may be responsible for the pattern of magnetization, which is incoherent throughout the section.

Interstitial water chemistry analysis showed significant positive gradients in $\mathrm{Ca}$ with increasing depth and negative gradients in $\mathrm{Mg}$. However, the gradients in Hole 504 are considerably smaller than those in Hole 501, revealing large lateral gradients in pore water chemistry that may be caused by very slow pore water migration through the sediments.

Principal results, Leg 69, Holes 504A, 504B (Cores 1-29), and 504C: Hole 504A was begun as a multiple re-entry site, but it had to be abandoned after only 12 meters of basalt were drilled because the bit disintegrated, leaving the cones and supporting shanks in the bottom of the hole. Hole $504 \mathrm{C}$ was drilled between bit changes at Hole 504B specifically for making point temperature measurements with the Tokyo T-probe (Yokota et al., 1980) and taking in situ pore water samples with the Barnes sampler in the sedimentary section (to $220 \mathrm{~m}$ ); no cores were taken. Hole 504B was established as a multiple re-entry site. Two hundred fourteen meters of basement were drilled and continuously cored. Four suites of logs were run in the basement section, and the inflatable packer was used three times to make two flow tests and to collect a large-volume sample of formation water. An ultrasonic televiewer and a down- hole magnetometer were also run in the hole. The last effort made in the leg was to obtain temperature and compensated density logs in Hole 504A, which had been thermally equilibrating for a month while Site 505 and Hole 504B were being drilled.

Since most of the results come from Hole 504B, with Holes $504 \mathrm{~A}$ and $504 \mathrm{C}$ providing only a small amount of supplementary data, all three holes are discussed together in this summary.

In Hole 504A the bottom of the sedimentary layer was cored along with 12 meters of basalt. The interval from 227 to 264 meters was comprised of chert and siliceous limestones of late Miocene age similar to those in Holes 501 and 504. The basement section yielded chrome-spinel-bearing basalts and lithologic units similar to those drilled in Hole 501.

The logging and experiments made at Hole 504B provided some surprising results. Two temperature logs taken 34 hours and 70 hours after circulation had stopped gave extremely low gradients to 365 meters sub-bottom and maximum temperatures only $7^{\circ}$ above bottom water, with virtually no change between the logs. Below 365 meters extremely high gradients were observed. (Temperatures in the bottom of the hole increased up to $5^{\circ} \mathrm{C}$ between the logs; evidently the hole was approaching an equilibrium profile appropriate for a conductive geothermal regime [see the results for Hole 504B, Leg 70].) The temperature measurements at three points sub-bottom in Hole $504 \mathrm{C}$ (which is just $60 \mathrm{~m}$ west of Hole 504B) showed a conductive gradient of about $24.5^{\circ} \mathrm{C} / 100 \mathrm{~m}$ in the sediments. If that gradient had held for Hole 504B the temperature at 365 meters sub-bottom would have indicated a temperature at the top of basement of about $60^{\circ} \mathrm{C}$. The only reasonable interpretation of the temperature profiles at Hole 504B is that cold water was flowing down the hole at rates of up to $50 \mathrm{gal} . / \mathrm{hr}$. and issuing into the basement formation 90 meters below the sediment/basement contact. The temperature log run in Hole 504A after it had equilibrated for a month showed a conductive profile.

The flow tests with the packer sealing the annulus between the drill pipe and hole walls showed that the basement has a hydraulic permeability from 2 to 40 millidarcys. 
The logging runs showed that the walls of the hole are free of projections and have relatively few voids. The logs giving information relevant to density, resistivity, compensated density, and neutron density all show that pillows and thin flows predominate in the column. There are, however, three massive flow units, one about 10 meters thick. More details of the wall structure were detected by the ultrasonic televiewer, which also showed that pillows and large fractures were common along the entire section.

The downhole magnetometer and measurements on samples showed that the basement to the depth drilled is reversely magnetized, in agreement with the magnetic anomalies measured at the sea surface. Inclinations of the magnetization are lower than in the present field.

Two samples of water were drawn at the bottom of Hole 504B reached during Leg 69 . One sample was $15 \mathrm{gal}$. Both contain a mix of fresh surface seawater and seawater that had been pumped down the hole earlier and had reacted extensively with the rocks. The latter is chemically similar to the pore waters in the basal sediments. Pore waters drawn from the sediments of Hole $504 \mathrm{C}$ indicate even smaller gradients in the $\mathrm{Ca}$ and $\mathrm{Mg}$ concentration than in Holes 504A or 501, although the shape of the profile is similar. The results suggest that the movement of the interstitial waters through the sediments is sluggish.

In the basement section at Hole 504B three types of basalt were distinguished. One contains phenocrysts of plagioclase, lesser olivine, and minor chrome spinel; the second contains phenocrysts of plagioclase, olivine, and clinopyroxene. The third embraces a range of textures from sparsely phyric to aphyric; when phenocrysts occur they are plagioclase, olivine, and augite. Twenty lithologic units were identified, with the rock types described above complexly interbedded. All the units are intensely fractured, and slickensides were detected on a few fracture faces. Tectonically produced polymict breccias are found in at least two zones.

The alteration of the basalts is moderate, with saponite, primarily, replacing olivine and filling voids. Zones of oxidative alteration border many cracks.

$\mathrm{XRF}$ analyses show that the basalts are generally uniform in composition. They are only moderately fractionated, with $\mathrm{Mg}$ / $\left(\mathrm{Mg}+\mathrm{Fe}\right.$ ) equalling 0.56 to $0.66, \mathrm{TiO}_{2}$ ranging from 0.7 to $1.4 \%$, and $\mathrm{Zr}$ ranging from 30 to $100 \mathrm{ppm}$.

Principal results, Leg 70, Hole 504B: Hole 504B was re-entered on December 3, 1979 at $1343 \mathrm{hr}$. During the 14 consecutive days on site, the hole was re-entered three more times, and 347 meters of basement were cored. On December 13 a depth of 836 meters sub-bottom was reached, making Hole 504B one of the deepest holes ever drilled in oceanic crust. (Later drilling on Leg 83 extended the penetration in basement to a record depth of $1075 \mathrm{~m}$.) Penetration rates varied from 2 to $6 \mathrm{~m} / \mathrm{hr}$., with an average close to $4 \mathrm{~m} / \mathrm{hr}$. Recovery varied from 0 to $100 \%$, with an average of $26.4 \%$.

The basement cored during Leg 70 at Hole 504B is made up of 26 petrographic units that correspond to 15 paleomagnetic units. Three major kinds of lava were encountered: massive flows (at least $23 \mathrm{~m}$ thick), flow breccias with highly fractured sequences of pillow lavas, and thin flows. The basalt ranges from aphyric to sparsely to highly olivine-plagioclase-clinopyroxene phyric. The association of the first two phenocryst minerals is the most common. Spinel microphenocrysts have been observed in a few units. Five petrographic types of basalt were distinguished on the basis of the occurrence of the various phenocryst minerals.

The alteration of the lowermost 347 meters of basalt drilled in Hole 504B during Leg 70 was slightly different from that of the upper 214 meters of basalt drilled during Leg 69 . The main differences were as follows:

1) No calcite was observed below 660 meters sub-bottom.

2) $\mathrm{Fe}$-oxyhydroxides were not common between 600 and 760 meters and below 800 meters sub-bottom.

3) Vein pyrite was not observed above 540 meters sub-bottom, but it became progressively more abundant with increasing depth. As in the Leg 69 portion of the hole, various types of smectite formed the most abundant alteration products, and the smectite was accompanied by small amounts of zeolite (analcite and natrolite were identified by X-ray diffraction [XRD]). A mixedlayer mineral was tentatively identified as saponite/talc by XRD. Olivine phenocrysts were frequently replaced by various combinations of talc, smectite, and red iddingsite (probably a Fe-oxyhy- droxide-rich smectite mixture). Preliminary reflected-light observations indicated that the igneous $\mathrm{Fe}-\mathrm{Ti}$ oxides were severely altered into mainly non-opaque secondary products ( $\mathrm{Fe}$ and $\mathrm{Ti}$ oxyhydroxides and possibly silicates), which filled up the large cracks that separated rather small Ti-magnetite relics. The basement alteration probably took place in mainly suboxic conditions in the upper portion of the hole (i.e., down to $540 \mathrm{~m}$ sub-bottom), and in suboxic to anoxic conditions in the lowermost 296 meters, or at least as far as the basement was drilled. The alteration process and the resulting products do not differ, as far as our shipboard observations indicate, from those due to basalt/seawater reactions at low temperature.

The paleomagnetic data suggest 15 units with an overall mean stable inclination of $-18^{\circ}$. Two of the units, both of which extend over five cores, have mean stable inclinations of $-53^{\circ}$ and $-63^{\circ}$, respectively, steeper than would be expected as a result of geomagnetic secular variation. Tectonic tilt, geomagnetic excursions, stable secondary remanence, or a combination of these might be responsible for these anomalous inclinations. The overall mean intensity of magnetization is $7 \times 10^{-3}$ gauss, and the overall mean $Q$ ratio is 10 .

The average sonic velocity of the basement rocks measured on board is significantly higher than the wave velocities derived from site survey data: 5.71 versus 4 to $5 \mathrm{~km} / \mathrm{s}$, respectively. This difference can be attributed to the widespread occurrence of fractures on a scale larger than exists in the cored samples; the fractures are probably responsible for the water flow.

Drilling was followed by an extensive logging and downhole measurement program. The logs that were successful over the entire basement section include the sonic, resistivity, temperature, and caliper logs. The natural gamma and neutron density logs were partially successful; the compensated density log was unsuccessful. The successful logs show prominent massive basalts at about 325 , 590 , and 690 meters below the mudline, and otherwise generally fractured and altered basalt. Downhole experiments included the large-scale electrical resistivity and oblique seismic experiments, the latter in cooperation with R/V Gilliss.

Four borehole temperature profiles and in situ water samples were made during the deepening of Hole 504B on Leg 70; one of each was made before any disturbance of the re-entered hole. These confirmed that the strong downward flow of cold water to 365 meters sub-bottom observed during Leg 69 was still occurring. The present flow rate down the cored hole was estimated at a few meters per hour. The data also suggest that a conductive gradient of about $0.12^{\circ} \mathrm{C} / \mathrm{m}$ exists below about 440 meters sub-bottom, yielding a heat flow rate of roughly $4.8 \mathrm{HFU}$, which is in good agreement with the Leg 69 result. The maximum temperature at the bottom of the hole on the last profile measured $111^{\circ} \mathrm{C}$; equilibrium temperature was estimated to be about $120^{\circ} \mathrm{C}$. Formation water silica concentration increased with depth, suggesting that water chemistry varied with increasing depth as a result of reactions with warmer basement rocks.

\section{INTRODUCTION}

Although Sites 501 and 504 were drilled on three different legs they are effectively the same site. Hole 501 was the pilot hole for two re-entry holes, Holes 504A and 504B, which are only a few hundred meters away. We have therefore combined the reports written for Sites 501 and 504, including the reports for the upper and lower portions of Hole 504B, which were written on Legs 68,69 and 70, into one chapter. In most sections, the results for Site 501 precede the results for Site 504. The background for and objectives of the drilling are presented in the introductory chapter to this volume.

\section{OPERATIONS}

\section{Hole 501}

The Glomar Challenger departed Puntarenas, Costa Rica, at $1049 \mathrm{hr}$. on 5 July 1979 for the experimental 
portion of Leg 68. At $1125 \mathrm{hr}$., after a 25 -min. period to test thrusters, the Challenger proceeded toward the site. Towed geophysical equipment was streamed at $1630 \mathrm{hr}$. at the 349-meter contour.

The Challenger reached the vicinity of Site 501 on the morning of 8 July and approached the site on course $085^{\circ}$. The beacon was dropped at $1228 \mathrm{hr}$. that day. The precision depth recorder (PDR) water depth was 3420 meters. A sediment thickness of 250 to 300 meters was indicated by single-channel profiler records obtained by the Challenger and site survey investigations (Fig. 1).

The bottom hole assembly (BHA), which included the Lynes packer with a circulating subassembly, was made up. Pressure tests were conducted on the BHA. The drill pipe was run down between $1500 \mathrm{hr}$. on $8 \mathrm{July}$ and 0315 hr. on 9 July. The first core was recovered at $0550 \mathrm{hr}$., establishing the seafloor depth as $\mathbf{3 4 6 6 . 9}$ meters. Another core (Core 2) was taken to confirm this depth.

The sediment coring program from the seafloor to approximately 230 meters below it consisted of washing five joints, taking a core, and measuring heat flow (Table 2). After Core 6, which was at 226.1 to 235.6 meters sub-bottom, continuous coring was undertaken until basaltic basement was reached at 264.1 meters. We planned to core continuously until we reached a basement formation that was firm enough to run the first hydrofracture experiment and other planned experiments.

In Core 12 we recovered 1.94 meters of basalt along with rubber fragments that represented portions of the inflatable packer element, which had been torn up during the drilling. We decided to core an additional 3 meters and then subject the packer to a pressure test to evaluate its operational capability. The test showed that the packer element would not hold above $1000 \mathrm{psi}$, which jeopardized the hydrofracture experiments but still allowed some experiments to be run. After this test, a packer formation sampler (with spike) test was made. Continuous coring in basalt began again at $0845 \mathrm{hr}$. on 11 July and was completed at $1320 \mathrm{hr}$. on 12 July 1979 .

The program of downhole experiments is given in Table 3. The pipe was then pulled to end operations at Site 501 .

\section{Interregnum}

Thruster problems experienced during the coring of Hole 501 necessitated the dry-docking of the Challenger for several weeks in Curaçao in the West Indies. Since the ship was in the Caribbean, its first operations following the dry-docking were hydraulic piston coring at Site 502 in the western Caribbean and at Site 503 in the eastern Pacific. A new scientific party was on board for this coring, which occupied the remainder of Leg 68. The Costa Rica Rift drilling finally recommenced on 20 September 1979 with most of the original scientific party, and a new leg number, Leg 69 , was assigned for this purpose.

\section{Hole 504}

The first hole drilled on Leg 69 is very close to Site 501. The track out from La Libertad, Ecuador, was planned so that we approached the site on a westerly course that was approximately parallel to the crustal isochrons and magnetic anomaly lineations. Observations of water depth, sediment thickness, and magnetics were made along the track.

Navigation during the first pass over Site 501 was uncertain because of the paucity of satellite fixes. The Site 501 beacon that was dropped on 8 July had ceased func-
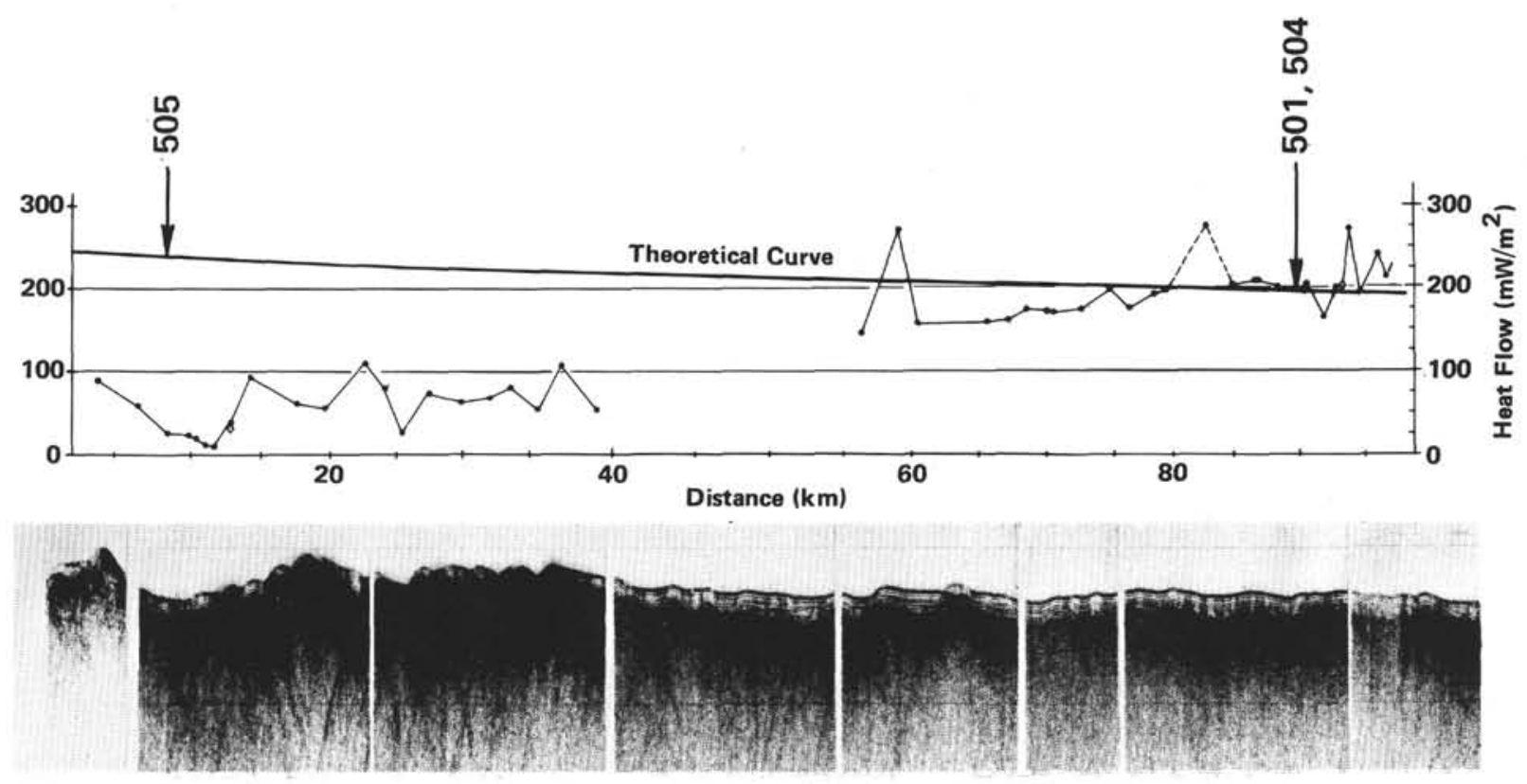

Figure 1. N-S profile of heat flow $\left(\mathrm{mW} / \mathrm{m}^{2}\right)$ plotted as a function of distance from the Costa Rica Rift axis (off figure to left) above a similarly scaled profiler record showing basement topography and sediment thickness. Projected locations of Sites 501/504 and 505 are shown. Heat flow was measured during the site survey and during Expedition Cocotow of Scripps Institution of Oceanography (Anderson and Hobart, 1976). 
Table 2. Coring summary-Sites 501 and 504 .

\begin{tabular}{|c|c|c|c|c|c|c|c|}
\hline Core & $\begin{array}{c}\text { Date } \\
(1979)\end{array}$ & Time & $\begin{array}{l}\text { Depth from } \\
\text { Drill Floor } \\
\text { (m) }\end{array}$ & $\begin{array}{l}\text { Depth } \\
\text { below } \\
\text { Seafloor } \\
\text { (m) }\end{array}$ & $\begin{array}{l}\text { Length } \\
\text { Cored } \\
(\mathrm{m})\end{array}$ & $\begin{array}{l}\text { Length } \\
\text { Recovered } \\
\text { (m) }\end{array}$ & $\begin{array}{c}\text { Recovery } \\
(\%)\end{array}$ \\
\hline \multicolumn{8}{|c|}{ Hole 501} \\
\hline 1 & 9 July & 0550 & $3466.9-3474.5$ & $0.0-7.6$ & 7.6 & 9.44 & $100+$ \\
\hline 2 & 9 & 0830 & $3466.9-3467.0$ & $0.0-0.1$ & 0.1 & $\operatorname{Tr}$ & - \\
\hline- & 9 & - & $3474.5-3522.0$ & \multicolumn{4}{|c|}{ (Wash 5 joints below base of Core 1 ) } \\
\hline 3 & 9 & 1115 & $3522.0-3531.5$ & $55.1-64.6$ & 9.5 & 9.55 & $100+$ \\
\hline - & 9 & - & $3531.5-3579.0$ & \multicolumn{4}{|c|}{ (Wash 5 joints below base of Core $2^{\mathrm{a}}$ ) } \\
\hline 4 & 9 & 1500 & $3579.0-3588.5$ & $112.1-121.6$ & 9.5 & 9.60 & $100+$ \\
\hline - & 9 & - & \multicolumn{5}{|c|}{ (Make heat flow/pore water measurements) } \\
\hline- & 9 & - & $3588.5-3636.0$ & & (Wash & joints) & \\
\hline 5 & 9 & 2055 & $3636.0-3645.5$ & $169.1-178.6$ & 9.5 & 4.03 & 42 \\
\hline - & 9 & - & \multicolumn{5}{|c|}{ (Make heat flow/pore water measurements) } \\
\hline- & 9 & - & $3645.5-3693.0$ & & (Wash & joints) & \\
\hline 6 & 10 & 0305 & $3693.0-3702.5$ & $226.1-235.6$ & 9.5 & 5.20 & 55 \\
\hline 7 & 10 & 0440 & $3702.5-3712.0$ & $235.6-245.1$ & 9.5 & 3.14 & 33 \\
\hline 8 & 10 & 0620 & $3712.0-3721.5$ & $245.1-254.6$ & 9.5 & 0.20 & 2 \\
\hline 9 & 10 & 0805 & $3721.5-3731.0$ & $254.6-264.1$ & 9.5 & 0.69 & 7 \\
\hline 10 & 10 & 1045 & $3731.0-3734.0$ & $264.1-267.1$ & 3.0 & 2.10 & 70 \\
\hline 11 & 10 & 1500 & $3734.0-3740.0$ & $267.1-273.1$ & 6.0 & 3.49 & 58 \\
\hline 12 & 10 & 2155 & $3740.0-3747.0$ & $273.1-280.1$ & 7.0 & 1.94 & 28 \\
\hline 13 & 11 & 0340 & $3747.0-3750.0$ & $280.1-283.1$ & 3.0 & 2.57 & 86 \\
\hline 14 & 11 & 1330 & $3750.0-3759.0$ & $283.1-292.1$ & 9.0 & 4.17 & 46 \\
\hline 15 & 11 & 1730 & $3759.0-3768.0$ & 292.1-301.1 & 9.0 & 4.06 & 45 \\
\hline 16 & ii & 2230 & $3768.0-3772.0$ & $301.1-305.1$ & 4.0 & 1.64 & 41 \\
\hline 17 & 12 & 0135 & $3772.0-3777.0$ & $305.1-310.1$ & 5.0 & 3.00 & 60 \\
\hline 18 & 12 & 0505 & $3777.0-3786.0$ & $310.1-319.1$ & 9.0 & 2.19 & 24 \\
\hline 19 & 12 & 0845 & $3786.0-3795.0$ & $319.1-328.1$ & 9.0 & 2.22 & 25 \\
\hline 20 & 12 & 1320 & $3795.0-3804.0$ & $328.1-337.1$ & 9.0 & 5.30 & 59 \\
\hline Total & & & & & 147.2 & 74.53 & 51 \\
\hline
\end{tabular}

Hole 504

\begin{tabular}{|c|c|c|c|c|c|c|c|}
\hline 1 & 20 Sept. & 1430 & $3480.0-3484.4$ & $10.0-14.4$ & 4.4 & 4.2 & 95 \\
\hline 2 & 20 & 1535 & $3484.4-3488.8$ & $14.4-18.8$ & 4.4 & 3.91 & 89 \\
\hline 3 & 20 & 1700 & $3488.8-3493.2$ & $18.8-23.2$ & 4.4 & 4.4 & 100 \\
\hline 4 & 20 & 1810 & $3493.2-3497.6$ & $23.2-27.6$ & 4.4 & 4.22 & 96 \\
\hline 5 & 20 & 1920 & $3497.6-3502.0$ & $27.6-32.0$ & 4.4 & 3.64 & 83 \\
\hline 6 & 20 & 2045 & $3502.0-3506.4$ & $32.0-36.4$ & 4.4 & 4.35 & 99 \\
\hline 7 & 20 & 2157 & $3506.4-3510.8$ & $36.4-40.8$ & 4.4 & 4.35 & 99 \\
\hline 8 & 20 & 2312 & $3510.8-3515.2$ & $40.8-45.2$ & 4.4 & 4.35 & 99 \\
\hline 9 & 21 & 0050 & $3515.2-3519.6$ & $45.2-49.6$ & 4.4 & 4.30 & 98 \\
\hline 10 & 21 & 0220 & $3519.6-3524.0$ & $49.6-54.0$ & 4.4 & 3.81 & 87 \\
\hline 11 & 21 & 0340 & $3524.0-3528.4$ & $54.0-58.4$ & 4.4 & 4.24 & 96 \\
\hline 12 & 21 & 0455 & $3528.4-3532.8$ & $58.4-62.8$ & 4.4 & 4.34 & 99 \\
\hline 13 & 21 & 0615 & $3532.8-3537.2$ & $62.8-67.2$ & 4.4 & 3.94 & 90 \\
\hline 14 & 21 & 0735 & $3537.2-3541.6$ & $67.2-71.6$ & 4.4 & 4.49 & 102 \\
\hline 15 & 21 & 0850 & $3541.6-3546.0$ & $71.6-76.0$ & 4.4 & 4.25 & 97 \\
\hline 16 & 21 & 1010 & $3546.0-3550.4$ & $76.0-80.4$ & 4.4 & 4.02 & 91 \\
\hline 17 & 21 & 1130 & $3550.4-3554.8$ & $80.4-84.8$ & 4.4 & 4.24 & 96 \\
\hline 18 & 21 & 1250 & $3554.8-3559.2$ & $84.8-89.2$ & 4.4 & 4.18 & 95 \\
\hline 19 & 21 & 1400 & $3559.2-3563.6$ & $89.2-93.6$ & 4.4 & 3.32 & 75 \\
\hline 20 & 21 & 1530 & $3563.6-3568.0$ & $93.6-98.0$ & 4.4 & 4.36 & 99 \\
\hline 21 & 21 & 1645 & $3568.0-3572.4$ & $98.0-102.4$ & 4.4 & 4.50 & 102 \\
\hline 22 & 21 & 1815 & $3572.4-3576.8$ & $102.4-106.8$ & 4.4 & 3.25 & 74 \\
\hline 23 & 21 & 1935 & $3576.8-3581.2$ & $106.8-111.2$ & 4.4 & 1.55 & 35 \\
\hline 24 & 21 & 2053 & $3581.2-2585.6$ & $111.2-115.6$ & 4.4 & 2.43 & 55 \\
\hline 25 & 21 & 2210 & $3585.6-3590.0$ & $115.6-120.0$ & 4.4 & 4.02 & 91 \\
\hline 26 & 21 & 2340 & $3590.0-3594.4$ & $120.0-124.4$ & 4.4 & 3.93 & 89 \\
\hline 27 & 22 & 0100 & $3594.4-3598.8$ & $124.4-128.8$ & 4.4 & 3.86 & 88 \\
\hline 28 & 22 & 0214 & $3598.8-3603.2$ & $128.8-133.2$ & 4.4 & 2.43 & 55 \\
\hline 29 & 22 & 0322 & $3603.2-3607.6$ & $133.2-137.6$ & 4.4 & 3.35 & 76 \\
\hline 30 & 22 & 0440 & $3607.6-3612.0$ & $137.6-142.0$ & 4.4 & 3.76 & 85 \\
\hline 31 & 22 & 0605 & $3612.0-3616.4$ & $142.0-146.4$ & 4.4 & 2.99 & 68 \\
\hline 32 & 22 & 0740 & $3616.4-3620.4$ & $146.4-150.8$ & 4.4 & 3.75 & 85 \\
\hline 33 & 22 & 0900 & $3620.8-3625.2$ & $150.8-155.2$ & 4.4 & 2.02 & 46 \\
\hline 34 & 22 & 1030 & $3625.2-3629.6$ & $155.2-159.6$ & 4.4 & 3.42 & 78 \\
\hline 35 & 22 & 1305 & $3629.6-3634.0$ & $159.6-164.0$ & 4.4 & 4.01 & 91 \\
\hline 36 & 22 & 1415 & $3634.0-3638.4$ & $164.0-168.4$ & 4.4 & 3.50 & 80 \\
\hline 37 & 22 & 1540 & $3638.4-3642.8$ & $168.4-172.8$ & 4.4 & 3.52 & 81 \\
\hline 38 & 22 & 1705 & $3642.8-3647.2$ & $172.8-177.2$ & 4.4 & 3.95 & 90 \\
\hline 39 & 22 & 1833 & $3647.2-3651.6$ & $177.2-181.6$ & 4.4 & 0.49 & 11 \\
\hline 40 & 22 & 1950 & $3651.6-3656.6$ & $181.6-186.0$ & 4.4 & 2.57 & 58 \\
\hline 41 & 22 & 2125 & $3656.0-3660.0$ & $186.0-190.0$ & 4.0 & 3.83 & 96 \\
\hline 42 & 22 & 2310 & $3660.0-3664.0$ & $190.0-194.0$ & 4.0 & 2.35 & 59 \\
\hline 43 & 23 & 0028 & $3664.0-3668.0$ & $194.0-198.0$ & 4.0 & 4.52 & 113 \\
\hline 44 & 23 & 0155 & $3668.0-3672.0$ & $198.0-202.0$ & 4.0 & 2.33 & 58 \\
\hline 45 & 23 & 0320 & $3672.0-3676.0$ & $202.0-206.0$ & 4.0 & 2.82 & 71 \\
\hline 46 & 23 & 0455 & $3676.0-3680.0$ & $206.0-210.0$ & 4.0 & 1.64 & 41 \\
\hline 47 & 23 & 0630 & $3680.0-3684.0$ & $210.0-214.0$ & 4.0 & 1.70 & 43 \\
\hline 48 & 23 & 0740 & $3684.0-3688.0$ & $214.0-218.0$ & 4.0 & 1.31 & 33 \\
\hline 49 & 23 & 0905 & $3688.0-3692.0$ & $218.0-222.0$ & 4.0 & 1.92 & 48 \\
\hline 50 & 23 & 1030 & $3692.0-3696.0$ & $222.0-226.0$ & 4.0 & 1.71 & 43 \\
\hline 51 & 23 & 1150 & $3696.0-3700.0$ & $226.0-230.0$ & 4.0 & 1.78 & 45 \\
\hline 52 & 23 & 1310 & $3700.0-3704.0$ & $230.0-234.0$ & 4.0 & 1.38 & 35 \\
\hline 53 & 23 & 1415 & $3704.0-3707.0$ & $234.0-237.0$ & 3.0 & 1.08 & 36 \\
\hline 54 & 23 & 1545 & 3707.0 & 237.0 & 0 & 0 & 0 \\
\hline Total & & & & & 227 & 174.58 & 77 \\
\hline
\end{tabular}

Hole 504A

$\begin{array}{llllllll}1 & 27 \text { Sept. } & 2200 & 3694.5-3704.0 & 226.5-236.0 & 9.5 & 0.63 & 6.6 \\ 2 & 27 & 2300 & 3704.0-3713.5 & 236.0-245.5 & 9.5 & 0.05 & 0.5\end{array}$
Table 2. (Continued).

\begin{tabular}{|c|c|c|c|c|c|c|c|}
\hline Core & $\begin{array}{l}\text { Date } \\
(1979)\end{array}$ & Time & $\begin{array}{l}\text { Depth from } \\
\text { Drill Floor } \\
\text { (m) }\end{array}$ & $\begin{array}{l}\text { Depth } \\
\text { below } \\
\text { Seafloor } \\
\text { (m) }\end{array}$ & $\begin{array}{l}\text { Length } \\
\text { Cored } \\
\text { (m) }\end{array}$ & $\begin{array}{l}\text { Length } \\
\text { Recovered } \\
\text { (m) }\end{array}$ & $\begin{array}{c}\text { Recovery } \\
(\%)\end{array}$ \\
\hline \multicolumn{8}{|c|}{ Hole 504A (Cont.) } \\
\hline 3 & 28 & 0115 & $3713.5-3723.0$ & $245.5-255.0$ & 9.5 & 1.52 & 16 \\
\hline 4 & 28 & 0330 & $3723.0-3729.0$ & $255.0-261.0$ & 6.0 & 1.08 & 18 \\
\hline 5 & 28 & 0540 & $3729.0-3733.0$ & $261.0-265.0$ & 4.0 & 0.68 & 17 \\
\hline 6 & 28 & 1055 & $3733.0-3741.0$ & $265.0-273.0$ & 8.0 & 3.22 & 40 \\
\hline 7 & 28 & 1505 & $3741.0-3745.0$ & $273.0-277.0$ & 4.0 & 1.83 & 46 \\
\hline Total & & & & & 70.5 & 9.01 & 20.58 \\
\hline
\end{tabular}

Hole 504B, Leg 69

(Washed to $260.5 \mathrm{~m}$ sub-bottom)

\begin{tabular}{|c|c|c|c|c|c|c|c|}
\hline 1 & 8 Oct. & 2145 & $3734.0-3743.5$ & $260.5-270.0$ & 9.5 & 1.24 & 13 \\
\hline 2 & 9 & 0040 & $3743.5-3750.5$ & $270.0-277.0$ & 7.0 & 0.96 & 14 \\
\hline \multicolumn{3}{|c|}{ (Drilled) } & $3750.5-3751.5$ & $277.0-278.0$ & 1.0 & & \\
\hline 3 & 12 & 0135 & $3751.5-3753.5$ & $278.8-280.0$ & 2.0 & 1.35 & 68 \\
\hline 4 & 12 & 0615 & $3753.5-3763.0$ & $280.0-289.5$ & 9.5 & 5.00 & 53 \\
\hline 5 & 12 & 1025 & $3763.0-3772.0$ & $289.5-298.5$ & 9.0 & 2.72 & 30 \\
\hline 6 & 12 & 1445 & $3772.0-3781.0$ & $298.5-307.5$ & 9.0 & 2.52 & 28 \\
\hline 7 & 12 & 1845 & $3781.0-3790.0$ & $307.5-316.5$ & 9.0 & 5.87 & 65 \\
\hline 8 & 12 & 2331 & $3790.0-3799.0$ & $316.5-325.5$ & 9.0 & 6.08 & 68 \\
\hline 9 & 13 & 0315 & $3799.0-3808.0$ & $325.5-334.5$ & 9.0 & 1.80 & 20 \\
\hline 10 & 13 & 0650 & $3808.0-3817.0$ & $334.5-343.5$ & 9.0 & 2.26 & 25 \\
\hline 11 & 13 & 1000 & $3817.0-3826.0$ & $343.5-352.5$ & 9.0 & 2.50 & 28 \\
\hline 12 & 13 & 1400 & $3826.0-3835.0$ & $352.5-361.5$ & 9.0 & 2.09 & 23 \\
\hline 13 & 13 & 1750 & $3835.0-3844.0$ & $361.5-370.5$ & 9.0 & 5.55 & 62 \\
\hline 14 & 13 & 2135 & $3844.0-3848.5$ & $370.5-375.0$ & 4.5 & 1.62 & 36 \\
\hline 15 & 14 & 0210 & $3848.5-3857.5$ & $375.0-384.0$ & 9.0 & 4.10 & 46 \\
\hline 16 & 14 & 0615 & $3857.5-3866.5$ & $384.0-393.0$ & 9.0 & 4.37 & 49 \\
\hline \multicolumn{8}{|c|}{ (Tripped pipe to change bit and make heat flow measurements) } \\
\hline 17 & 17 & 0615 & $3866.5-3871.5$ & $393.0-398.0$ & 5.0 & 2.33 & 47 \\
\hline 18 & 17 & 1050 & $3871.5-3876.5$ & $398.0-403.0$ & 5.0 & 1.50 & 30 \\
\hline 19 & 17 & 1625 & $3876.5-3885.5$ & $403.0-412.0$ & 9.0 & 1.87 & 21 \\
\hline 20 & 17 & 2128 & $3885.5-3894.5$ & $412.0-421.0$ & 9.0 & 0.92 & 10 \\
\hline 21 & 18 & 0110 & $3894.5-3903.5$ & $421.0-430.0$ & 9.0 & 4.39 & 49 \\
\hline 22 & 18 & 0710 & $3903.5-3912.5$ & $430.0-439.0$ & 9.0 & 2.24 & 25 \\
\hline 23 & 18 & 1212 & $3912.5-3921.5$ & $439.0-448.0$ & 9.0 & 1.10 & 13 \\
\hline 24 & 18 & 1643 & $3921.5-3930.5$ & $448.0-457.0$ & 9.0 & 3.47 & 38 \\
\hline 25 & 18 & 2220 & $3930.5-3936.5$ & $457.0-463.0$ & 6.0 & 2.28 & 38 \\
\hline 26 & 19 & 0030 & $3936.5-3939.5$ & $463.0-466.0$ & 3.0 & 0.62 & 21 \\
\hline 27 & 19 & 0350 & $3939.5-3948.5$ & $466.0-475.0$ & 9.0 & 1.28 & 14 \\
\hline 28 & 19 & 0850 & $3948.5-3957.5$ & $475.0-484.0$ & 9.0 & 3.86 & 43 \\
\hline 29 & 19 & 1120 & $3957.5-3962.5$ & $484.0-489.0$ & 5.0 & 0.77 & 15 \\
\hline
\end{tabular}

Hole 504B, Leg 70

\begin{tabular}{|c|c|c|c|c|c|c|c|}
\hline 30 & 4 Dec. & 0552 & $3962.5-3972.0$ & $489.0-498.5$ & 9.5 & 0 & 0 \\
\hline 31 & 4 & 0940 & $3972.0-3981.0$ & $498.5-507.5$ & 9.0 & 0 & 0 \\
\hline 32 & 4 & 1503 & $3981.0-3990.0$ & $507.5-516.5$ & 9.0 & 2.94 & 33 \\
\hline 33 & 4 & 1850 & $3990.0-3999.0$ & $516.5-525.5$ & 9.0 & 2.38 & 26 \\
\hline 34 & 4 & 2304 & $3999.0-4008.0$ & $525.5-534.5$ & 9.0 & 2.21 & 25 \\
\hline 35 & 5 & 0229 & $4008.0-4017.0$ & $534.5-543.5$ & 9.0 & 1.66 & 18 \\
\hline 36 & 5 & 0650 & $4017.0-4026.0$ & $543.5-552.5$ & 9.0 & 4.72 & 52 \\
\hline 37 & 5 & 1209 & $4026.0-4035.0$ & $552.5-561.5$ & 9.0 & 2.66 & 30 \\
\hline 38 & 5 & 1531 & $4035.0-4044.0$ & $561.5-570.5$ & 9.0 & 2.30 & 26 \\
\hline 39 & 5 & 1901 & $4044.0-4053.0$ & $570.5-579.5$ & 9.0 & 2.90 & 32 \\
\hline 40 & 6 & 0009 & $4053.0-4057.5$ & $579.5-584.0$ & 4.5 & 5.75 & $100+$ \\
\hline 41 & 6 & 0448 & $4057.5-4066.5$ & $584.0-593.0$ & 9.0 & 4.40 & 49 \\
\hline 42 & 6 & 0823 & $4066.5-4075.5$ & $593.0-602.0$ & 9.0 & 1.5 & 17 \\
\hline 43 & 6 & 1156 & $4075.5-4084.5$ & $602.0-611.0$ & 9.0 & 1.39 & 15 \\
\hline 44 & 6 & 1521 & $4084.5-4093.5$ & $611.0-620.0$ & 9.0 & 2.00 & 22 \\
\hline 45 & 6 & 1820 & $4093.5-4102.5$ & $620.0-629.0$ & 9.0 & 1.87 & 21 \\
\hline 46 & 6 & 2145 & $4102.5-4111.5$ & $629.0-638.0$ & 9.0 & 2.85 & 32 \\
\hline 47 & 7 & 0221 & $4111.5-4120.5$ & $638.0-647.0$ & 9.0 & 3.82 & 42 \\
\hline 48 & 7 & 0607 & $4120.5-4129.5$ & $647.0-656.0$ & 9.0 & 3.10 & 34 \\
\hline 49 & 7 & 1331 & $4129.5-4138.5$ & $656.0-665.0$ & 9.0 & 2.73 & 30 \\
\hline 50 & 8 & 2329 & $4138.5-4143.0$ & $665.0-669.5$ & 4.5 & 0.30 & 6 \\
\hline 51 & 9 & 0421 & $4143.0-4152.0$ & $669.5-678.5$ & 9.0 & 0.90 & 10 \\
\hline 52 & 9 & 0923 & $4152.0-4161.0$ & $678.5-687.5$ & 9.0 & 4.05 & 45 \\
\hline 53 & 9 & 1153 & $4161.0-4165.5$ & $687.5-692.0$ & 4.5 & 0.37 & 8 \\
\hline 54 & 9 & 1414 & $4165.5-4170.0$ & $692.0-696.5$ & 4.5 & 1.58 & 35 \\
\hline 55 & 9 & 1700 & $4170.0-4179.0$ & $696.5-705.5$ & 9.0 & 1.27 & 14 \\
\hline 56 & 9 & 2001 & $4179.0-4188.0$ & $705.5-714.5$ & 9.0 & 1.78 & 20 \\
\hline 57 & 10 & 0027 & $4188.0-4197.0$ & $714.5-723.5$ & 9.0 & 3.9 & 43 \\
\hline 58 & 10 & 0512 & $4197.0-4206.0$ & $723.5-732.5$ & 9.0 & 3.86 & 43 \\
\hline 59 & 10 & 0816 & $4206.0-4215.0$ & $732.5-741.5$ & 9.0 & 0.40 & 4 \\
\hline 60 & 10 & 1232 & $4215.0-4224.0$ & $741.5-750.5$ & 9.0 & 1.85 & 21 \\
\hline 61 & 11 & 1752 & $4224.0-4228.5$ & $750.5-755.0$ & 4.5 & 2.31 & 26 \\
\hline 62 & 11 & 2036 & $4228.5-4237.5$ & $755.0-764.0$ & 9.0 & 1.60 & 18 \\
\hline 63 & 12 & 0115 & $4237.5-4246.5$ & $764.0-773.0$ & 9.0 & 3.85 & 43 \\
\hline 64 & 12 & 0630 & $4246.5-4255.5$ & $773.0-782.0$ & 9.0 & 4.55 & 51 \\
\hline 65 & 12 & 0948 & $4255.5-4264.5$ & $782.0-791.0$ & 9.0 & 1.10 & 12 \\
\hline 66 & 12 & 1611 & $4264.5-4273.5$ & $791.0-800.0$ & 9.0 & 2.41 & 27 \\
\hline 67 & 12 & 1904 & $4273.5-4282.5$ & $800.0-809.0$ & 9.0 & 0.95 & 11 \\
\hline 68 & 12 & 2154 & $4282.5-4291.5$ & $809.0-818.0$ & 9.0 & 0.80 & 9 \\
\hline 69 & 13 & 0013 & $4291.5-4300.5$ & $818.0-827.0$ & 9.0 & 1.00 & 11 \\
\hline 70 & 13 & 0415 & $4300.5-4309.5$ & $827.0-836.0$ & 9.0 & 1.48 & 16 \\
\hline Total & & & & & 574.5 & 168.15 & 29.3 \\
\hline
\end{tabular}

a No heat flow/pore water measurements possible at this level because of malfunctions of heave compensator. 
Table 3. Logging and downhole measurement operations-Holes 501, 504A, 504B, and 504C.

\begin{tabular}{|c|c|c|c|}
\hline $\begin{array}{c}\text { Date } \\
(1979)\end{array}$ & $\begin{array}{c}\text { Time } \\
\text { Interval }\end{array}$ & Operations & Comment \\
\hline \multicolumn{4}{|l|}{ Hole 501} \\
\hline 9 July & $1505-1700$ & Downhole temperature & Valid measurement \\
\hline 9 & $2155-2400$ & Downhole temperature & Valid measurement \\
\hline 12 & 1330 & Completion of drilling & \\
\hline 12 & $1330-1630$ & Packer flow tests & Inflatable element severely damaged \\
\hline 12 & $1630-2300$ & Clean and prepare hole for logging & \\
\hline 13 & $2300-0530$ & Sonic and natural gamma caliper logs & Sonic tool didn't work \\
\hline 13 & $0530-1200$ & $\begin{array}{l}\text { Gamma compensated density, natural } \\
\text { gamma, caliper, and temperature } \\
\text { logs }\end{array}$ & Natural gamma questionable \\
\hline 13 & $1200-2400$ & Borehole televiewer & Excellent results \\
\hline 14 & $0000-1300$ & Downhole magnetometer & $\begin{array}{l}\mathrm{H}_{\mathrm{x}}, \mathrm{H}_{\mathrm{y}}, \mathrm{H}_{\mathrm{z}} \text { good data, poor } \\
\text { magnetic susceptibility }\end{array}$ \\
\hline 14 & $1300-1900$ & Temperature log and sampler & Sampler collapsed \\
\hline 14 & $1900-2345$ & Clean hole, flush with mud & \\
\hline 15 & $0000-0415$ & $\begin{array}{l}\text { Laterolog, neutron density, natural } \\
\text { gamma }\end{array}$ & $\begin{array}{l}\text { Excellent natural gamma gave } \\
\text { anomalous results in base }\end{array}$ \\
\hline 15 & $0615-1645$ & Large-scale resistivity experiment & $\begin{array}{l}\text { Valid measurements obtained at } 10-\mathrm{m} \\
\text { intervals }\end{array}$ \\
\hline \multicolumn{4}{|l|}{ Hole 504A } \\
\hline 26 Oct. & $0600-0900$ & $\begin{array}{l}\text { Temperature, caliper, natural gamma } \\
\text { sampler }\end{array}$ & Valid results, good sample \\
\hline \multicolumn{4}{|c|}{ Hole 504B, Leg 69} \\
\hline $\begin{array}{l}19 \text { Oct. } \\
20 / 21\end{array}$ & $\begin{array}{l}1130 \\
2020-2000\end{array}$ & $\begin{array}{l}\text { Drilling stopped at } 3962.5 \mathrm{~m} \\
\text { Packer flow tests at } 3790 \mathrm{~m} \text { and } \\
3959.5 \mathrm{~m}\end{array}$ & Flow tests valid \\
\hline 22 & $1600-2100$ & $\begin{array}{l}\text { Natural gamma, compensated density, } \\
\text { caliper temperature }\end{array}$ & Valid data \\
\hline $22 / 23$ & $2145-0145$ & $\begin{array}{l}\text { Guard resistivity, neutron density, } \\
\text { natural gamma }\end{array}$ & Valid data \\
\hline 23 & $0200-1150$ & Downhole magnetometer & Unsuccessful on two runs \\
\hline 23 & $1200-2200$ & Borehole televiewer & $\begin{array}{l}\text { Fair performance, lowering useful } \\
\text { record obtained }\end{array}$ \\
\hline $23 / 24$ & $2200-0200$ & Sonic velocity & Failed on trip down \\
\hline 24 & $0315-0800$ & Downhole magnetometer & Successful run \\
\hline $24 / 25$ & $0830-2225$ & Packer sampler & $\begin{array}{l}\text { Sampler filled, inflatable element } \\
\text { destroyed }\end{array}$ \\
\hline \multicolumn{4}{|c|}{ Hole 504B, Leg 70} \\
\hline 3 Dec. & $3473-3933$ & $\begin{array}{l}\text { Temperature } \log \text { with Tokyo T-probe } \\
\text { in drill bit }\end{array}$ & $\begin{array}{l}54 \text { days after Leg } 69 \text { departure from } \\
\text { hole }\end{array}$ \\
\hline 8 & $3837-4129$ & $\begin{array}{l}\text { Temperature log with Tokyo T-probe } \\
\text { in drill bit }\end{array}$ & $\begin{array}{l}30 \mathrm{hr} \text { after cessation of coring } \\
\text { operations }\end{array}$ \\
\hline 13 & $0430-1100$ & $\begin{array}{l}\text { Clean out hole, pull above mudline, } \\
\text { drop bit, re-enter hole }\end{array}$ & \\
\hline 13 & $1305-1753$ & $\begin{array}{l}\text { Sonic log (interval velocity and } \\
\text { spectrum), natural gamma, caliper, } \\
\text { maximum temperature }\end{array}$ & All tools operated satisfactorily \\
\hline $13 / 14$ & $1836-0210$ & Oblique seismic experiment & Instrument malfunctioned \\
\hline 14 & $0230-1650$ & Large-scale electrical resistivity & Good data obtained \\
\hline 14 & $1805-2330$ & $\begin{array}{l}\text { Temperature log; compensated density, } \\
\text { natural gamma, caliper, and } \\
\text { maximum temperature }\end{array}$ & $\begin{array}{l}\text { Density tool did not operate. } \\
\sim 40 \mathrm{hrs} \text {. after cessation of } \\
\text { circulation }\end{array}$ \\
\hline 15 & $0000-2115$ & Oblique seismic experiment & Satisfactory travel time data \\
\hline $15 / 16$ & $2318-0510$ & $\begin{array}{l}\text { Guard resistivity, neutron density, } \\
\text { natural gamma }\end{array}$ & $\begin{array}{l}\text { Resistivity tool failed on way down } \\
\text { at } 3800 \mathrm{~m} \text {, density }\end{array}$ \\
\hline 16 & $0520-0915$ & Temperature log and water sampler & $\begin{array}{l}\text { Satisfactory. }-75 \mathrm{hr} \text { after cessation } \\
\text { of circulation }\end{array}$ \\
\hline 16 & $0945-1421$ & $\begin{array}{l}\text { Guard resistivity, natural gamma, } \\
\text { neutron density }\end{array}$ & $\begin{array}{l}\text { Resistivity okay, neutron density only } \\
\text { partly successful }\end{array}$ \\
\hline 16 & $1421-2355$ & Pull drill string and magnaflux BHA & \\
\hline \multicolumn{4}{|l|}{ Hole 504C } \\
\hline 14 Oct. & $1232-1410$ & Downhole temperature and IPWS ${ }^{\mathrm{a}}$ & Valid measurement \\
\hline 14 & $1601-1800$ & Downhole temperature and IPWS & No valid measurement-failed battery \\
\hline 14 & $1917-2100$ & Downhole temperature and IPWS & Valid measurement \\
\hline 14 & $2242-2400$ & Downhole temperature and IPWS & Valid measurement \\
\hline
\end{tabular}

tioning, so it could not be used as a reference. The Glomar Challenger maneuvered in the vicinity until a reliable fix could be obtained. The beacon for Site 504 was dropped at $0413 \mathrm{hr}$. local time on 20 September 1979 based on dead reckoning from the last reliable fix, and subsequent satellite fixes showed this new beacon to be $0.9 \mathrm{~km}$ due east of Site 501 .

The location of Hole 504 is 250 meters east and 90 meters south of Hole 501 (Fig. 2 and Table 4). A bottom hole assembly designed for the hydraulic piston corer (HPC) was made up and the pipe was run in on the morn- ing of 20 September. After touching bottom the bit washed down to approximately 10 meters below the mudline ( $3480 \mathrm{~m}$ below the derrick floor), and hydraulic piston coring began at that point.

Continuous hydraulic piston coring was carried out to a depth of 237 meters ( 53 cores) without a serious malfunction (Table 2). At this depth chert layers were encountered, as anticipated from the Site 501 results, which the HPC could not penetrate, and coring was stopped. The recovery rate of the piston coring was $95 \%$ in the upper 100 meters. Below this depth the sediment 

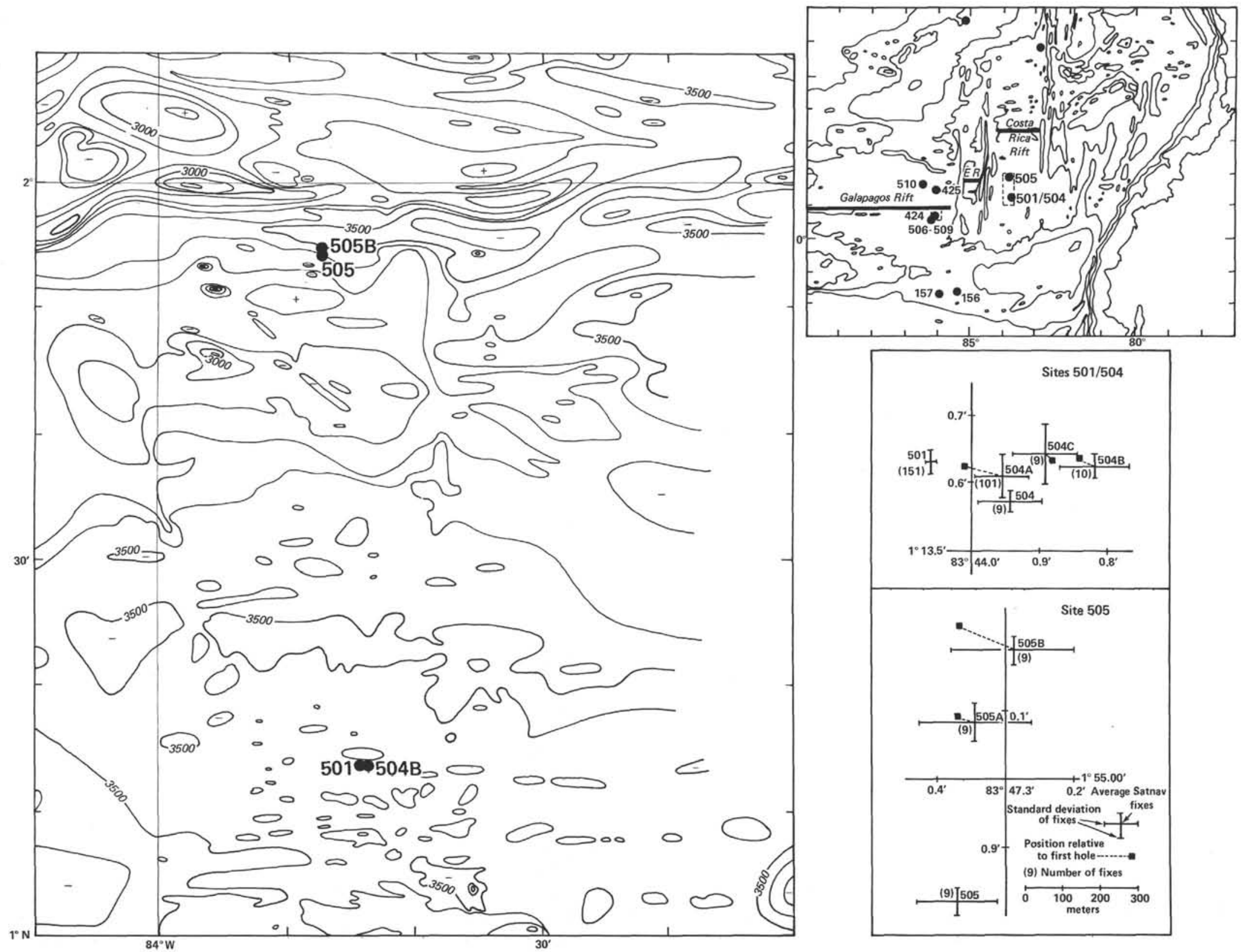

Figure 2. Bathymetry of the Costa Rica Rift flank near drill Sites 501, 504, and 505 (from CRRUST, 1982). At the upper right is an index map of the Galapagos Spreading Center: locations of other DSDP sites are shown. At lower right are magnified maps of the hole locations at the sites. For some sites, two positions are given: (1) the position based on the average of satellite navigation fixes (shown by crossed lines) and (2) positions relative to the first hole at a site based on offsets of the Glomar Challenger's dynamic positioning system (shown by squares). 
Table 4. Positions of Holes 501 and 504.

\begin{tabular}{lccccc}
\hline & \multicolumn{2}{c}{ Mean of Satnav ${ }^{\mathrm{a}}$ Fixes } & & \multicolumn{2}{c}{ Relative to First Hole ${ }^{\mathrm{b}}$} \\
\cline { 2 - 3 } \cline { 5 - 6 } Hole & $\begin{array}{c}\text { Latitude } \\
\text { N }\end{array}$ & $\begin{array}{c}\text { Longitude } \\
\text { W }\end{array}$ & & $\begin{array}{c}\text { Latitude } \\
\mathrm{N}\end{array}$ & $\begin{array}{c}\text { Longitude } \\
\text { W }\end{array}$ \\
\hline 501 & $1^{\circ} 13.63^{\prime}$ & $83^{\circ} 44.06^{\prime}$ & - & - \\
504 & $1^{\circ} 13.571^{\prime}$ & $83^{\circ} 43.942^{\prime}$ & - & - \\
$504 \mathrm{~A}$ & $1^{\circ} 13.609^{\prime}$ & $83^{\circ} 43.955^{\prime}$ & $1^{\circ} 13.622^{\prime}$ & $83^{\circ} 44.007^{\prime}$ \\
$504 \mathrm{~B}^{\mathrm{c}}$ & $1^{\circ} 13.624^{\prime}$ & $83^{\circ} 43.819^{\prime}$ & $1^{\circ} 13.632^{\prime}$ & $83^{\circ} 43.843^{\prime}$ \\
$504 \mathrm{C}$ & $1^{\circ} 13.642^{\prime}$ & $83^{\circ} 43.891^{\prime}$ & $1^{\circ} 13.633^{\prime}$ & $83^{\circ} 43.884^{\prime}$ \\
\hline
\end{tabular}

a Satellite navigation.

b Location relative to the first hole drilled at the site (504) is based on offsets from the beacon set into the positioning computer. Location of first site is assumed to be the mean of Satnav fixes.

c Position of Hole 504B, based on Leg 70 navigation, is $1^{\circ} 13.63^{\prime} \mathrm{N}$ and $83^{\circ} 43.81^{\prime} \mathrm{W}$.

became more consolidated and stronger, and the recovery rate decreased. A significant decrease in recovery rate also occurred between 100 meters and 115 meters sub-bottom, which does not coincide with any abrupt change in physical properties of the sediments. Full extension of the piston core barrel was achieved at each firing to a depth of 175 meters, with a single exception at 111 meters. At depths greater than 175 meters, 10 out of 15 cores showed evidence of extension shorter than 4.4 meters.

For the first 39 cores the bit was advanced 4.4 meters by washing regardless of the amount of recovery or penetration. Beginning with Core 40 , the bit was washed down only 4.0 meters after each core and the bit face was raised $40 \mathrm{~cm}$ above the bottom of the hole before the piston corer was fired. Core 53 penetrated a chert layer that was probably a few centimeters thick and obtained a $100-\mathrm{cm}$ section of softer chalk beneath. The rim of the cutting edge was peened over by the chert. A last core, Core 54, was attempted in Hole 504, but no sample was obtained and the core catcher was badly damaged.

Operations at Hole 504 ended at 2330 hr. on $23 \mathrm{Sep}-$ tember 1979.

\section{Hole 504A}

After the completion of drilling operations at Hole 504 the ship was shifted to a point approximately 100 meters north and 120 meters west of Hole 504. With the beacon as the reference point this location was about 100 meters east of Site 501 (Fig. 2 and Table 4), and a reentry hole was begun. The running of the pipe was slowed by problems with the thrusters. A 90-meter section of 16-in. casing was washed down into the sediments, and the cone was set.

At that point the bit was released from the casing and washed down to a depth of 97 meters sub-bottom. A bottom hole temperature measurement and in situ water sampler were tried at this depth, but leakage of seawater into the pressure housing ruined the observations. A second heat flow and in situ pore water sampler (HF/ IPWS) run was made after washing down 152 meters sub-bottom. The probe became jammed in the bit and could not be retrieved by the sandline. As a result the drill pipe was pulled back on board. Again, the heat flow and in situ pore water sampler observations were ruined because of the leakage of water into the pressure core.

At $0600 \mathrm{hr}$. on 27 September re-entry was made and the bit was washed to a depth of 3694.5 meters. This depth placed the bit about 7.5 meters above the first chert zone. From this depth continuous rotary coring began. The basement was reached at $\mathbf{3 7 3 2}$ meters, 264 meters sub-bottom. A 14 7/8-in bit was used during the first phase of the drilling to open a hole for the second length of 11-in. casing. Drilling was slow, with much torque, and at about midnight on 28 September very high torque and no downward progress indicated possible bit damage. The drill string was pulled from the hole for a second time, and we discovered that two of the cones and the shanks that supported them had broken off the large-diameter bit and remained in the hole. Since the two large roller cones and steel fragments lying in the bottom of the hole would have taken considerable time and perhaps special equipment to remove, we decided to stop operations at Site 504 temporarily and move to Site 505 . We left Site 504 at about $0800 \mathrm{hr}$. on 29 September. While we were at Site 505, a new re-entry cone was prepared for our return to Site 504 .

\section{Hole 504B, Setup and Initial Re-Entries}

Following the completion of the program at Site 505 at about $1800 \mathrm{hr}$. on 7 October 1979 , we returned to Site 504 to begin a second re-entry. On the way south from Site 505 standard underway geophysical measurements were made along a line parallel to, and 2 miles east of, the track made going northward. The location of Hole 504B is about 300 meters east of Hole 504A (Fig. 2).

The operation of setting up a new multiple re-entry site, which included casing the hole through 275 meters of sediment to basement, took 4 days and was completed by $2015 \mathrm{hr}$. on 8 October. At 260.5 meters subbottom we began coring. The first two cores contained chert and siliceous chalk. Igneous basement was encountered at $\mathbf{3 7 4 8}$ meters sub-bottom.

After we drilled a short distance into basement, we flushed the hole with mud and seawater and pulled the large-diameter drill pipe out of the hole. The hole was re-entered at $1330 \mathrm{hr}$. on 10 October, and 275 meters of $113 / 4$-in. casing was run into the hole and cemented into basement. After the casing operation, the string was once again pulled up on deck and a bottom hole assembly, including a standard 97/8-in bit, was made in preparation for basement drilling. We re-entered for the second time on 11 October at $1616 \mathrm{hr}$.

Continuous coring was carried out from $0000 \mathrm{hr}$. on 12 October to $0630 \mathrm{hr}$. on 14 October, reaching a depth of 393 meters sub-bottom. Fourteen cores, consisting of pillow basalts, one massive flow, and several thin flows, were taken. The rocks recovered were highly fractured, and sticks of core more than $20 \mathrm{~cm}$ long were rare. The drilling conditions were relatively good, and penetration rates were normal. On the average we required 4 to $5 \mathrm{hr}$. 
to cut a 9-meter core. The heave compensator system was used during coring, and it appeared to make drilling smoother, with less torque.

\section{Hole 504C}

After Core 16 was taken at Hole 504B, we decided to change the bit. However, before bringing the bottom hole assembly back on deck, we offset $200 \mathrm{ft}$. west of the cone and washed down through the sedimentary section to 220 meters to make four bottom hole temperature measurements and take in situ pore water samples (Table 3). This hole was designated Hole 504C even though no cores were taken. Three of the four temperature measurements were successful, and all four of the in situ sampling attempts were successful, although chemical evidence indicates that the two deepest samples are strongly contaminated by circulating seawater. We believe this to be due to the incomplete closing of the valve on the sampler after the fluids in the sediment had been drawn. The heave compensator was used during the operations at Hole 504C, and this helped to hold the bit steady, even in weak sediments.

\section{Hole 504B, Additional Coring}

After the completion of Hole 504C the drill string was brought on deck. Preparations were made for the third re-entry into Hole 504B. In an effort to improve knowledge of bit movements during re-entry, a sonar reflector with a mooring weight was set on the bottom about $\mathbf{3 0}$ meters north of the cone. While the ship was being maneuvered back to the cone in preparation for reentry it suffered a major power failure; without power for maintaining position or operating the drilling equipment, the ship began to drift northward in the prevailing currents. This carried us into shallower water, allowing the drill string to drag along the soft bottom. When power was restored we pulled the bottom hole assembly back on board to inspect it and to magnaflux its most vulnerable sections. The bottom hole assembly proved to be sound, so we started back down immediately for another attempt at re-entry. This was achieved at 2230 hr. on 16 October. The bit was run back to the bottom of the hole, and we began the second segment of basement drilling and coring in Hole 504B. Coring was carried out without interruption until $1130 \mathrm{hr}$. on 19 October, when it stopped after a total penetration of $489 \mathrm{me}-$ ters sub-bottom (Table 2). As before, the drilling went quite smoothly, with little torquing. The penetration rate was on the average about 40 meters per day. Core recovery was variable but predominantly low $(28 \%)$. Highly fractured basalt, rounded pieces, and some brecciated basalt were recovered. The pipe was then pulled up on deck to begin the experimental and logging phase of the program.

\section{Hole 504B, Experiments and Logging, Leg 69}

The bottom hole assembly was changed to include the Lynes packer subassembly, the hydraulic bit release, and torque jars. After the packer was assembled we lowered it just below the waterline and began testing. The first test showed that the packer subassembly was not operating properly, but the fault was corrected and the assembly was successfully tested before it was sent down for a fourth re-entry.

The fourth re-entry at Hole 504B was made at 2020 hr. on 20 October. We ran down the hole to 3790 meters, where coring had revealed a massive flow unit, and conducted the first series of pulse and flow tests. The packer was successfully inflated and the plug was blown. The packer remained inflated so that several flow tests were carried out. They revealed the lower 120 meters of the hole to be quite permeable (Zoback and Anderson, this volume).

The go-devil was retrieved, the bit was lowered to the bottom of the hole, and a second series of tests was successfully executed. The packed-off section of the hole lost pressure slowly, requiring more than $15 \mathrm{~min}$. to decay to 300 psi. However, it proved impossible to retrieve the go-devil. We wrestled with this problem until about $2000 \mathrm{hr}$. on 21 October, when we decided that we would have to trip the drill string.

Once back on deck we discovered that the fishing head of the go-devil was covered by over a foot of rust, but the packer element was in good condition.

The fifth re-entry for logging Hole 504B was achieved at $1330 \mathrm{hr}$ on 22 October. To preserve the established temperature gradient we lowered the bottom of the pipe only 60 meters into the casing. The logs and experiments run in Hole 504B are listed in Table 3.

The drill hole proved to be remarkably clean and free of obstructions. The tools could be lowered to 3952 meters without difficulty. This was 10 to 11 meters shy of the bottom, so some type of fill blocked the lowest part of the hole.

The Soviet downhole magnetometer was run three times. During the first run, susceptibility and vertical component measurements were successfully measured, but the horizontal component measurements were highly variable (Ponomarov and Nekhoroshkov, this volume). During the second run only the horizontal components were measured, but they were again plagued by highly variable signals. A third run from 0315 to 0800 $\mathrm{hr}$. on 24 October gave much better results on the horizontal sensors.

The borehole televiewer was run successfully into the hole. This was a major achievement, since the instrument had suffered significant damage in transit to the ship. In repairing it we used a transducer from one of the re-entry tool heads, and many modifications in the electronics and mechanical operation of this rather complex tool had to be made. The records were noisy, especially near the top of the hole, but performance improved greatly as the instrument was lowered deeper in the hole. With 2 days remaining at the site during Leg 69 we planned further packer tests, including drawing a large-volume sample at in situ pressure with the annulus of the hole packed off, and additional flow tests above and below what appeared to be a highly permeable zone where water was flowing down the hole and into the basement rocks. 
The bottom hole assembly with the packer was run back downhole starting at $2300 \mathrm{hr}$. on 24 October. The sixth re-entry at Hole 504B was made at $0723 \mathrm{hr}$. on 25 October. The bit with the power subassembly in place was run into the hole to a total depth of 3962.5 meters. A bridge that had been stoppping logging tools at about 3950 meters was knocked out by the bit. The hole was flushed with 50 barrels of barite mud and then with seawater.

The packer sampler actuating tool, together with the sampler, which stands nearly $70 \mathrm{ft}$. $(21.3 \mathrm{~m})$ high, was dropped down the hole at $1415 \mathrm{hr}$. Pressure was applied to inflate the packer and open the sampler-filling part. When pressure was bled off, the BHA was found firmly stuck in the bottom of the hole. The sampler was retrieved with the sandline; it contained a good sample. The 15-gal. sampler space was filled with water and exsolved gas. The bit remained stuck, so some additional flow tests were made. We noted that the pressure at the bottom of the hole fell off more and more rapidly with each test. After these tests, we found that the bit could be worked up about 10 meters; then it became stuck again. However, the pipe could be rotated, indicating that the packer element had probably been broken free by torquing. The drill string was pulled up against considerable friction in the hole. Since it appeared that the hole would be endangered if we tried to run in again, we decided to end operations in Hole 504B at this point. We pulled the bit above the mudline at $2225 \mathrm{hr}$. on 25 October. We then offset the vessel to the cone at Hole 504A for logging in that hole, which had last been disturbed on 29 September (Table 2). A logging run to 3744.6 meters in Hole 504A was successful.

\section{Hole 504B, Leg 70}

The operations in Hole 504B during Leg 70 were centered mainly on the continuous coring of basement rock, and logging the hole after coring terminated. We cut 41 cores in basement between 489 and 836 meters sub-bottom over a period of about 9 days (Table 2). Table 3 gives a summary of the logging and downhole measurement operations made after we drilled and cored to final depth.

The Glomar Challenger arrived in the vicinity of Hole 504B on the evening of 1 December 1979 after following a generally eastward track from Site 510 . Sonic pulses from the beacon left on Leg 69 were observed on the depth recorder as the vessel passed over the site, but when we returned to the vicinity (without good satellite fixes for several hours), the pulses were irregular. An occasional good beacon fix allowed the vessel to approach near enough to drop a new beacon at $2303 \mathrm{hr}$. on 1 December.

After running in the drill string to near the mudline, the sonar scanning tool was deployed for finding the reentry cone. The tool did not rotate properly, however, and after several unsuccessful attempts we decided to pull the drill string and inspect the bit assembly. The bit was on board at $2245 \mathrm{hr}$. on 2 December. Tests indicated that nothing was wrong; the tool operated satisfactorily at the surface. Therefore, the drill string was run back down, and the sonar scanning tool was run in again. We again had difficulty rotating the scanner until we discovered that reducing the pump pressure allowed it to operate normally. In the meantime, the numerous satellite fixes received after dropping the beacon had allowed the vessel to be positioned rather accurately over the site location determined on Leg 69, and when the sonar scanning tool became operable the re-entry cone was seen only about 20 meters away. Re-entry was accomplished at $1343 \mathrm{hr}$. on 3 December after about $3 \mathrm{hr}$. of maneuvering.

After we lowered the bottom hole assembly about 40 meters into the hole to be certain that re-entry had been properly effected, we ran in the temperature measurement device (Tokyo T-probe) and Barnes pore water sampler and successfully lowered them to the bottom of the hole by running in the drill string. Then Cores 30 to 49 (Table 2) were cut until we decided to change the bit. (There was no recovery in Cores 30 and 31 , evidently owing to the presence of torn pieces of the packer element left in the hole during Leg 69.) The drill string was pulled above the mudline at $1140 \mathrm{hr}$. on 7 December to drop the bit in anticipation of re-entry and to attempt some downhole measurements. However, we were unsuccessful in dropping the bit, so by $2130 \mathrm{hr}$. on $7 \mathrm{De}-$ cember the drill string was brought back on board. At the surface we discovered that the bit had dropped off, so the release had probably operated, but not completely. The bit was changed and the drill string run back down, and re-entry was accomplished at $1232 \mathrm{hr}$. on 8 December.

The Tokyo T-probe/pore water sampler was then run again as before to the bottom of the hole. Continuous coring resumed at $1245 \mathrm{hr}$. on 8 December, and Cores 50 to 60 were cut. The variations in the diameter of the recovered cores caused doubt about the condition of the bit, so we brought the drill string back on board for a bit change. The bit still appeared to be in reasonably good condition, but we replaced it with a new bit nonetheless and re-entry was accomplished at $0750 \mathrm{hr}$. on 11 December 1979. The Tokyo T-probe/pore water sampler was run as before to the bottom of the hole; a water sample was successfully obtained, but the temperature-measuring instrumentation did not function properly.

We then resumed continuous coring until $0430 \mathrm{hr}$. on 13 December 1979, during which time Cores 61 to 70 were cut. Drilling conditions remained excellent throughout, with drilling rates running at more than $4 \mathrm{~m} / \mathrm{hr}$., even though recovery was low. However, time constraints for Leg 70 required that we begin an extensive program of logging and downhole measurements at this point. Therefore the drill string was pulled above mudline, the bit was successfully released outside the hole, and re-entry was accomplished for the fourth and final time (on Leg 70) at $1055 \mathrm{hr} ., 13$ December 1979.

The logging program (Table 3 ) was completed at about $1420 \mathrm{hr}$. on 16 December, and the drill string was brought on board shortly before midnight. Hole 504B was left clean for possible future drilling, and the ship departed 
for port shortly after $0018 \mathrm{hr}$. on 17 December. Seismic reflection profiling was carried out on a southerly course away from Hole 504B.

\section{SEDIMENT STRATIGRAPHY AND LITHOLOGY}

\section{Hole 501}

The sediment column for Hole 501 was spot cored (10 cores) to basement; total sediment recovery was $\mathbf{4 1 . 9 5}$ meters (Fig. 3). The total sediment thickness was 264 meters. Essentially the same sedimentary types were encountered as at Site $\mathbf{5 0 4}$ for the respective depth intervals, except for the top 10 meters, which were not cored at Site 504.

Core 1 of Hole $501(0-7.6 \mathrm{~m})$ consists of siliceous carbonate core. Its basic color is dark greenish gray. The calcareous biogenic fraction (average: 53\%) consists mainly of nannofossils ( $23 \%$ of the total sediment), foraminifers $(18 \%)$, and unspecified carbonate particles $(12 \%)$. The siliceous biogenic fraction (average: $26 \%$ ) is formed by diatoms $(12 \%)$, radiolarians $(8 \%)$, sponge spicules $(6 \%)$, and traces of silicoflagellates. Clay-sized material in the core averages $12 \%$. There is also a significant amount of colorless volcanic glass in the core, with an average abundance of $5.7 \%$. Trace components are glauconite, opaque minerals, and other detrital constituents. Drilling disturbance has largely obliterated the sedimentary structures. However, the sediment seems to be bioturbated, and relief bedding is indicated by changes in the color, grain size, and composition of the sediments. Components of volcanic glass of 10 and $15 \%$ were found at 5.49 and 7.05 meters and may represent disseminated ash layers decomposed by bioturbation and drilling.

Since the remaining cores in Hole 501 resemble sediments that were continuously cored nearby at Site 504, and since the Site 504 sediments are very little disturbed by drilling, the remaining Hole 501 cores are not described here.

\section{Site 504 Summary}

The sedimentary sequence for Site 504 consists of three lithologic units (Fig. 3):

1) Unit 1 (0 to $143.5 \mathrm{~m}$ )-late Pleistocene to late Pliocene siliceous-nannofossil and nannofossil-radiolarian oozes, variably clay bearing;

2) Unit II (143.5 to $227.2 \mathrm{~m}$ )-late Plicoene to late Miocene siliceous-nannofossil chalk; and

3) Unit III (227.2 to $271 \mathrm{~m}$ )-late late Miocene interbedded nannofossil chalk, limestone, and chert.

In Holes 501, 504A, and 504B basaltic basement was reached at 264, 262, and 271 meters, respectively (Fig. 3 ). The differences are due to the slightly undulating basement relief. In Hole 504A the first limestone layer, which was intercalated in nannofossil chalk and was only a few centimeters thick, was reached at $\mathbf{2 2 7 . 2}$ meters. In Hole 504 the first encounter with limestone occurred deeper, at $\mathbf{2 3 4 . 2}$ meters. The uppermost dense limestone/ chert beds shown by the televiewer record and the logging data occur between 235 and 237 meters, however. Therefore it is very likely that at Hole 504 the hydraulic piston corer went through the thin limestone layer found at Hole 504A without recovery before it reached the dense limestone/chert beds.

The oozes and chalk of Units I and II consist mainly of calcareous nannofossils, with other fossil remains such as radiolarians, diatoms, silicoflagellates, sponge spicules, and foraminifers. Within the clay-sized fraction, montmorillonite is the major constituent. Colorless rhyolitic volcanic glass and pyrite are minor but significant constituents. The pyrite and the prevailing green hues are characteristic of the reduced oxidation state throughout Units I and II. Both units are moderately to intensively bioturbated. Relict bedding is evidenced by changes in color, composition, grain-size distribution, and $\mathrm{CaCO}_{3}$ content. Except for a few discrete ash layers, no sharp lithologic boundaries are apparent.

Units I and II exhibit differences in induration, marked by sudden changes in porosity, shear strength, and thermal conductivity (see Wilkens and Langseth, this volume). They also differ in color (Unit I is darker), $\mathrm{CaCO}_{3}$ content (Unit II is generally higher), and fossil preservation (fossil debris is more fragmented in Unit II). Corrosion on foraminifers and echinoderm spicules is common in Unit II, as is calcitic overgrowth on discoasters. In the middle part of Unit I there is also a remarkable increase in the content of siliceous fossil remains.

Unit III was clearly derived from the same basic material as the units above, since it also has radiolarians, diatoms, silicoflagellates, sponge spicules, foraminifers, and nannofossils and is comparably burrowed. However, increased dissolution and fragmentation often make microfossil recognition difficult. Silica dissolution and pore-filling redeposition of opal-A and its transformation toward opal-CT as well as chalcedony and quartz led to a considerable degree of chertification. It is clear that the unit boundaries at Site 504 are basically diagenetic boundaries.

\section{Lithologic Units, Site 504}

\section{Unit I (Cores 501-1 to 504-31, 0-143.5 m)}

Unit I consists of siliceous-nannofossil and nannofossil-radiolarian oozes and is variably clay bearing. It may be subdivided into three subunits as follows on the basis of differences in color.

\section{Subunit IA (Cores 501-1 to 504-13, 0-65 m)}

Subunit IA is an early to late Pleistocene nannofossilradiolarian ooze, sometimes clay bearing. Its prevailing colors are greenish gray, dusky yellow green, grayish green, and grayish yellow green, with some olive in the top 10 meters. Color layering is more frequent in the subunit's upper part but is visible throughout. Extensive bioturbation has mottled the colors considerably. Zoophycos burrows are especially prominent.

The average grain-size distribution shows that the subunit is composed of $5 \%$ sand-sized ( $>63 \mu \mathrm{m}$ ), $84 \%$ silt-sized, and $11 \%$ clay-sized (visual estimate) material. The $\mathrm{CaCO}_{3}$ content measured on board by the Karbonat Bombe method averages $41 \%$ and stems mainly from 


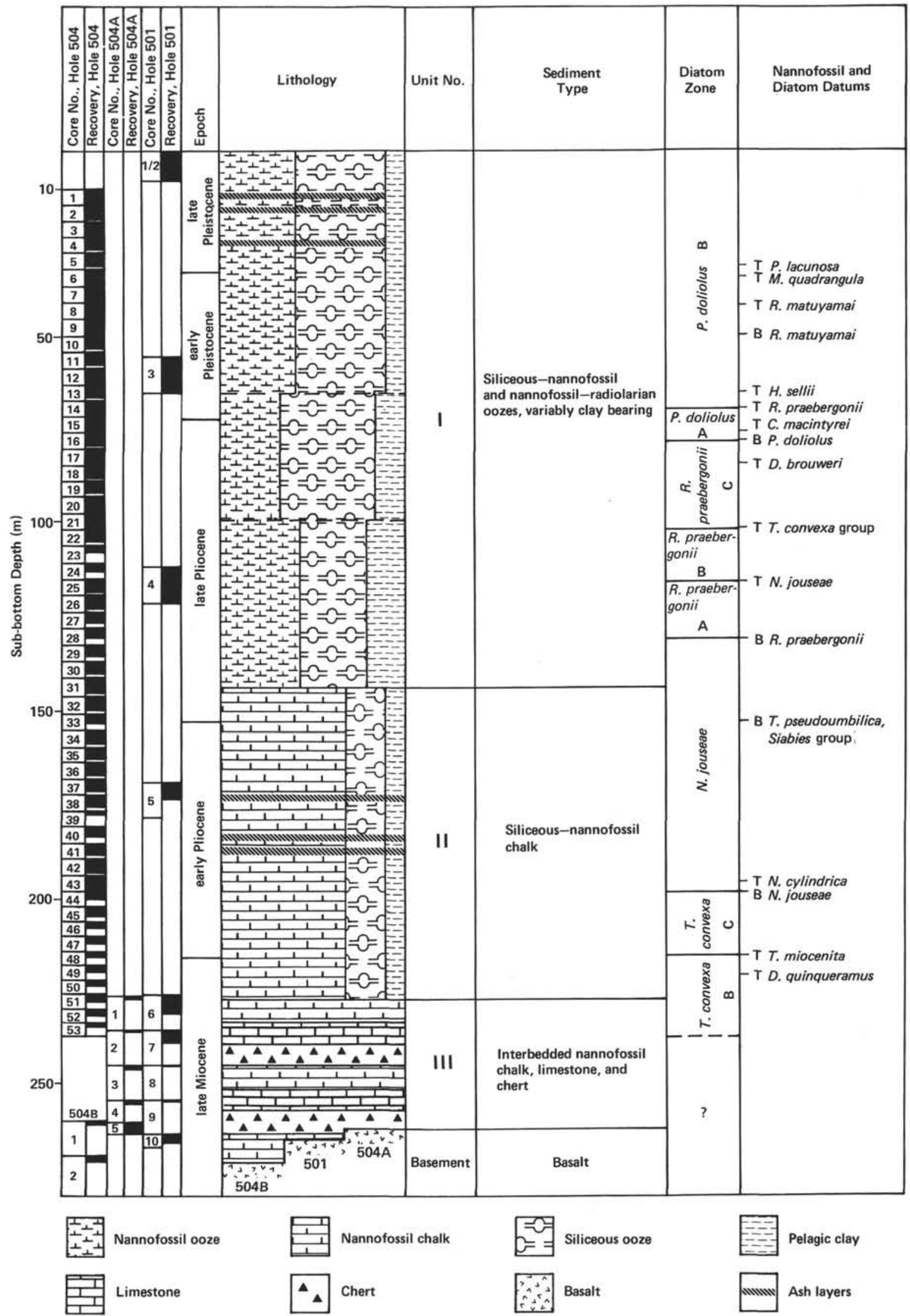

Figure 3. Summary of sediment lithology, diatom zonation scheme, and datum levels, Sites 501 and 504. A, B, C-diatom subzones. T, B-top, bottom occurrences of indicator fossils. 
calcareous nannofossils and a considerably smaller portion of foraminiferal material (intact tests and fragments). The siliceous biogenic portion of the sand- and silt-sized fractions consists mainly of radiolarians and diatoms; silicoflagellates and sponge spicules are minor constituents. Montmorillonite is the major component of the clay-sized fraction. Besides three distinct volcanic ash layers (at $12.25,14.95$, and $28.75 \mathrm{~m}$ ), there is an increased amount $(2-5 \%)$ of disseminated glass at both ends of the subunit. In the middle part, glass drops below $1 \%$. The intervals with higher volcanic glass content show more vertical burrowing.

\section{Subunit IB (Cores 504-13 to 504-21, 65-99 m)}

Subunit IB is an early Pleistocene to late Pliocene clay-bearing nannofossil-radiolarian ooze. Its prevailing colors are dusky to grayish yellow green and light to dark olive gray and olive. Color layering is less significant than in Subunit IA. Bioturbation is less significant than in Subunit IA insofar as Zoophycos burrows and large vertical burrows are concerned. The average grainsize distribution shows $4 \%$ sand-sized ( $>63 \mu \mathrm{m}), 80 \%$ silt-sized, and $16 \%$ clay-siz̀ed (visual estimate) material. The clay-sized portion of the sediment is large in the upper part (up to $35 \%$ ) and low in the lower part of the subunit $(<10 \%)$. The mean $\mathrm{CaCO}_{3}$ content in the subunit is $32 \%$. With the increasing content of clay-sized material, the $\mathrm{CaCO}_{3}$ content decreases. The different grain-size fractions of Subunit IB are generally formed by the same constituents as those of the subunit above it. There is a remarkable increase in the content of siliceous fossil remains, as compared with Subunit IA; however, the preservation of all microfossils is quite poor, with only dissolution-resistant species remaining. Volcanic glass rarely exceeds $1 \%$ and is nowhere higher than $2 \%$. No volcanic ash layers were observed.

\section{Subunit IC (Cores 504-21 to 504-31, 99-143.5 m)}

Subunit IC is a late Pliocene clay-bearing siliceousnannofossil ooze. The prevailing colors are greenish gray in the upper part and light olive gray in the lower part of the subunit. Color layering is less significant than in Subunit IB. Zoophycos burrows are more frequent than in Subunit IB and are increasingly visible with depth, whereas large vertical burrows like those in the overlying subunits were not observed. As in the case of Subunit IB, large burrow halos with dark gray and purple rinds become abundant. The average grain-size distribution shows that the subunit is composed of $3 \%$ sandsized, $76 \%$ silt-sized, and $21 \%$ clay-sized material. The clay-sized portion is large (up to 50\%) in the upper half and small (6-15\%) in the lower half of the subunit. The constituents of the different grain-size fractions are the same as in the subunits above. The $\mathrm{CaCO}_{3}$ content averages $44 \%$. It is lower where the clay-sized portion of the sediment is higher (minimum $\mathrm{CaCO}_{3}: 12 \%$ ) and higher where the clay-sized portion is lower (maximum $\mathrm{CaCO}_{3}$ : $50 \%$ ). Volcanic glass occurs mainly as traces. The pyrite content shows its maximum at the top of the subunit, where it reaches $3 \%$. The firmness of the sediments of the subunit increases considerably with depth, leading abruptly into chalk.

\section{Unit II (Cores 504-31 to 504A-1, 143.5-227.2 m)}

Unit II consists of siliceous-nannofossil chalk. The sometimes clay-bearing chalk is characterized by colors of light gray, light greenish gray, and very pale green. Color changes are less numerous than in Unit I. Bioturbation is intense. Remarkable large halos around the burrows are prominent throughout the chalk sequence (see also Subunit IC). The average grain-size distribution shows $2.5 \%$ sand-sized, $87.5 \%$ clay-sized, and $10 \%$ clay-sized material. The constituents of the different grain-size fractions are the same as in Unit I. The $\mathrm{CaCO}_{3}$ content of Unit II averages $69 \%$. It rises more or less continuously toward the base of the chalk. Volcanic glass occurs mainly as traces, except for three discrete ash layers at $173,183.4$, and 187.35 meters and a glassrich layer at 200 meters (probably a dispersed ash layer). Pyrite occurs as traces only and is therefore generally less abundant than in Unit I. In the upper half of the chalk sequence there is a remarkable increase in unspecified carbonate particles. From 168.4 meters downward irregular signs of corrosion on foraminifers become significant, and from 198 meters downward corrosion on echinoderm spicules becomes apparent as well. From 160 meters downward calcitic overgrowth of discoasters is strongly enhanced, showing increased diagenetic calcite dissolution and reprecipitation.

\section{Unit III (Cores 504A-1 to 504B-2, 227.2-271 m)}

Unit III consists of interbedded nannofossil chalk, limestone, and chert. The basic colors are light greenish gray for chalk, light greenish gray and yellowish gray for limestone, and medium dark gray for chert. All rock types show strong vertical compaction, which has produced fine horizontal lamination and flaser structures. The compaction as measured on Zoophycos burrows was approximately $80 \%$. However, in the chalk as well as in the limestones, numerous open foraminifer chambers occur. The nannofossil chalks and limestones show only traces of radiolarians and diatoms. The limestones are biomicrites, showing abrupt differences in composition on a microscopic scale. Their matrix consists of unspecified carbonate and nannofossils. Where foraminifer chambers have collapsed, their fragments are arranged parallel to the lamination of the rock. Pyrite is a minor constituent but is often concentrated in the direction of the laminae. Although the chalk/limestone boundaries are sharp, there are many transitions between limestones, porcellanites, and cherts. With increasing depth a tendency toward chertification becomes more apparent, although this impression is based on limited recovery. The thickness of the layers of each rock type varies, but the chert beds never seem to exceed a few centimeters in thickness, appearing rather as layers a few millimeters thick or as stringers. Irregularly chertified portions within the limestone and nodular chert also appear. Calcitic shells in the silicified portions of the limestones are mainly filled with chalcedony, but opal- 
CT lepispheres with chalcedony-filled chambers can also be seen. Partial or total replacement of the calcitic shell material also occurs.

\section{BIOSTRATIGRAPHY}

The Pliocene/Pleistocene boundary, which is defined by the last appearance of Rhizosolenia praebergonii, occurs 70 meters sub-bottom, in Core 14 , Section 2 of Hole 504. The last occurrence of Discoaster brouweri occurs almost 15 meters lower, at 84 meters sub-bottom (Core 17, Section 3). However, calcareous nannofossils are so rare and poorly preserved throughout the claybearing interval (65-102 m sub-bottom) that the actual upper limit of the distribution of $D$. brouweri may be higher in the section. It is thus not as reliable a market for the boundary as $R$. praebergonii.

The Miocene/Pliocene boundary (last occurrence of Thalassiosira miocenica) occurs at 215 meters sub-bottom, in Sample 504-48,CC. The last occurrence of $D$. quinqueramus is probably just below this $(220 \mathrm{~m}$ subbottom, Sample 504-49,CC.). However, overgrowth of discoasters is quite advanced at this depth, so the datum is open to question.

It was not possible to date the remainder of the section, because diagenesis has destroyed all of the diatoms and severely altered the calcareous nannofossils.

Figure 3 gives the diatom zones and datum levels for Sites 501 and 504. A few datums for calcareous nannofossils are also given. These are less reliable because of the rarity of marker species in some intervals and the generally poor preservation resulting from diagenesis (lower part) or carbonate dissolution (upper part).

\section{SEDIMENT PHYSICAL PROPERTIES}

A comprehensive program of physical properties measurement was carried out during the piston coring segment of the Site 504 investigation. Use of the hydraulic piston corer for sediment recovery allowed the measurements to be made in relatively undisturbed core sections. Compressional wave seismic velocities were measured using the Hamilton frame velocimeter. Wet bulk density, grain density, porosity, and water content analyses were carried out using gravimetric techniques. Thermal conductivity was determined using the standard needle probe apparatus. A modified Wykeham Farrance vane apparatus was used to measure sedimentary shear strength. Penetrometer measurements in close proximity to the vane shear measurements yielded relative values of the same parameter. Complete data and detailed discussion of the results in comparison with Site 505 are contained in Wilkens and Langseth (this volume).

\section{Sonic Velocity}

One Hamilton frame seismic velocity measurement was made in each section of the core. Velocities are fairly uniform throughout the column, with a mean velocity of $1.51 \mathrm{~km} / \mathrm{s}$ in the interval from 10 to 145 meters subbottom followed by an abrupt increase to a mean of $1.53 \mathrm{~km} / \mathrm{s}$ below 145 meters sub-bottom. In general the variations between maxima and minima are smooth, suggesting that the variation is real, but small excursions from the mean of up to $0.03 \mathrm{~km} / \mathrm{s}$ occur in both the upper and lower units. These small excursions do not readily correlate with the other physical properties measured.

The velocity range for the entire column is 1.48 to $1.56 \mathrm{~km} / \mathrm{s}$, which is in good agreement with what is expected from unconsolidated pelagic siliceous-nannofossil ooze. Two additional velocities were measured in atypical materials. A 2-cm-thick ash layer 187 meters sub-bottom yielded a seismic velocity of $1.65 \mathrm{~km} / \mathrm{s}$, and a chert fragment from 232 meters sub-bottom, which was measured out of the core liner, had a velocity of $4.25 \mathrm{~km} / \mathrm{s}$.

\section{Wet Bulk Density and Water Content}

Determinations of wet bulk density and water content were made on each core section. From these, grain density and porosity were derived. Both wet bulk density and grain density exhibit significant variation through the sediment column. At approximately 140 meters sub-bottom mean bulk density increases abruptly from $1.32 \mathrm{~g} / \mathrm{cc}$ (for the upper group of cores) to 1.48 $\mathrm{g} / \mathrm{cc}$ (for the lower group of cores). Particularly gratifying is the excellent correlation between fine-scale variations in wet bulk density determined from measured samples of Hole 504 and the bulk densities computed from compensated density logs run at Site 501, some 200 meters distant from Site 504. Such measurement agreement lends weight to the interpretation of the finescale variations as real phenomena.

Two sections above the 140-meter level exhibit somewhat uniform wet bulk and grain densities. Between 10 and 65 meters sub-bottom and again between 90 and 140 meters sub-bottom, wet bulk density values range between 1.30 and $1.34 \mathrm{~g} / \mathrm{cc}$. Between these intervals is a zone of lower bulk density (minimum: $1.20 \mathrm{~g} / \mathrm{cc}$ ) and grain density (minimum: $2.24 \mathrm{~g} / \mathrm{cc}$ ). Below the 140meter sub-bottom break, grain density decreases, but in contrast to the zone discussed previously, the bulk density increases.

\section{Thermal Conductivity}

Thermal conductivity $(\varkappa)$ measurements were made on unconsolidated sediment using the standard needle probe technique. (The needle was inserted into the sediment core before the core was opened by drilling a small hole through the liner.) Usually the cores had been in the laboratory for several hours before the measurements were made so that they had nearly reached laboratory temperature. A measurement was made on almost every core section (every $1.5 \mathrm{~m}$ ). In all, 121 observations were made in the cores from Hole 504.

The profile of conductivity $(x)$ versus depth, like some of the other physical properties, can be divided into two distinct groups. In the interval from 10 to 140 meters sub-bottom, the values show a gradual increase with depth from values near $0.75 \mathrm{~W} / \mathrm{m}^{\circ} \mathrm{C}$ near the seafloor to $0.85 \mathrm{~W} / \mathrm{m}^{\circ} \mathrm{C}$ at 140 meters sub-bottom. The values near the top of the interval are in good agreement with the values measured on piston cores taken during the site survey. In the interval from 145 to 235 meters 
the $x$ values are significantly higher. Although they exhibit greater variability than the results in the upper interval, a positive gradient with depth is indicated.

Variations of thermal conductivity at the scale of 10 meters are observed in the upper (10-140 m) unit. A local maximum at 60 meters sub-bottom is followed by a local minimum centered at 75 meters sub-bottom. Significant variations at these depths also occur in the bulk density. It is well established that the thermal conductivity of unconsolidated seafloor sediment depends principally on water content. Thus, the $x$ measurements provide an independent indication of the variation of water content with depth. The general agreement between the $x$ profile and the profiles of gravimetric data provide strong support that the small-scale variations are real.

\section{Shear Strength Tests}

The penetrometer experiment is performed by dropping a needle from a height of $1 \mathrm{~cm}$ above the sediment and recording the depth of penetration. Penetrability exhibited a steady decrease down the core, with readings showing rather remarkable consistency through the column. There is a perceptible change in slope at approximately 55 meters sub-bottom that could indicate a change in the rate of compaction. Within this interval, initial compaction has a larger effect on penetrability than the more gradual compaction undergone at lower levels in the sediments.

Vane shear measurements were made by applying increasing torque at a constant rate to a four-bladed vane embedded in the sediment. Final values of shear strength were determined from the amount of torque applied to the vane through a calibrated spring at the time of the failure of the sediment.

Values of shear strength at the top of the core of 100 to $200 \mathrm{~g} / \mathrm{cm}^{2}$ are in good agreement with measurements from deep ocean piston cores of pelagic sediments. Values increase with relatively small scatter to a sub-bottom depth of 100 meters. Below 100 meters the scatter increases greatly, but after a zone of relatively low strength between 100 and 120 meters the trend continues to be one of increasing shear strength. The low strength zone coincides with an interval of poor core recovery, and cores recovered in this interval may have been affected by some mechanical disruption.

Maximum values of shear strength $\left(1600 \mathrm{~g} / \mathrm{cm}^{2}\right)$ were recorded at approximately 170 meters sub-bottom. Below this depth a rock saw was employed to split the cores. Greatly reduced values of shear strength in the bottom 60 meters of the hole are probably due to mechanical disruption during the core-splitting process.

In summary, the physical properties of the unconsolidated sediments in Hole 504 can be readily separated into two groups. Group 1 corresponds to Lithologic Unit $\mathrm{I}$, which is found at 10 to 140 meters sub-bottom, and Group 2 corresponds to Lithologic Unit II, which is at 145 to 235 meters sub-bottom. Within Group 1, sonic velocities are extremely uniform over the entire interval, averaging $1.51 \mathrm{~km} / \mathrm{s}$; the gravimetric data bulk density averages $1.32 \mathrm{~g} / \mathrm{cc}$; and porosity averages $80 \%$. There are significant variations in these parameters which are related to the composition and structure of the solid fraction. Thermal conductivity shows a small and uniform positive gradient from 10 to 145 meters sub-bottom, with variations that correlate closely with the density and porosity profiles.

In Group 2 all of the previously discussed parameters have significantly different mean values, and the change in all cases seems to occur within a zone only 5 meters thick, defining a break in the physical properties of the sedimentary column. In this deeper interval, bulk density increases to a mean of $1.48 \mathrm{~g} / \mathrm{cc}$, and porosity decreases to about $67 \%$. This results in a significant decrease in the mean grain density to about $2.4 \mathrm{~g} / \mathrm{cc}$. In the Group 1 sediments, values of $2.55 \mathrm{~g} / \mathrm{cc}$ predominate. Thermal conductivity values of the Group 2 sediments are also higher, ranging from 1.1 to $1.4 \mathrm{~W} / \mathrm{m}^{2}$.

\section{SEDIMENT PORE WATER CHEMISTRY}

Interstitial water analyses from the various holes show similar patterns with depth: $\mathrm{Ca}^{2+}$ increases and $\mathrm{Mg}^{2+}$ decreases over the upper 175 meters to nearly constant values below that depth, and both alkalinity and chlorinity exhibit a maximum within the upper 100 meters. Although the directions of change for the various species are the same from hole to hole, the magnitudes of these changes differ greatly for some species, in direct relation to the geographic position of the hole. Thus, the data define lateral gradients for $\mathrm{Ca}^{2+}, \mathrm{Mg}^{2+}$, and alkalinity which are nearly as large as the vertical gradients. The sediment pore water chemistry is apparently dominated by seawater/basalt reactions in the basement, and the lateral gradients are believed to result from the differential propagation of this basement signal through the sediments by diffusion or advection or both. These points are discussed further in the chapters by Mottl and others on the elemental and isotopic chemistry of the interstitial waters.

\section{BASEMENT LITHOSTRATIGRAPHY}

\section{Hole 501}

At Hole 501, we drilled 73 meters of basement, recovering 37.63 meters for $44.7 \%$ recovery. Using the occurrence of cooling-unit boundaries, phenocryst mineralogy, and rock textures as a basis, we divided this section into 11 stratigraphic units made up of three of the five types of basalt defined in the petrographic section of this chapter. (The types in Hole 501 are Types 1, 2, and 4.) In the following section, the 11 stratigraphic units recovered are described in the order encountered during drilling. A brief summary of the features of these units, information on the intervals in the cores, and the approximate depths of the units are given in Table 5.

\section{Unit 1 (Core 10, Section 1-Core 11, Section 1; Basalt Type 2)}

Six cooling margins, consisting of either pillow lavas or thin flows, were recovered in Unit 1 . The basalt is almost aphyric (microphyric). Plagioclase phenocrysts (1 $\mathrm{mm}$ in length) are rare $(<2 \%)$. The rocks contain 1 to $2 \%$ of olivine and clinopyroxene microphenocrysts. Pla- 
Table 5. Summary of basement lithologic units, Hole 501.

\begin{tabular}{|c|c|c|c|c|c|}
\hline \multirow[b]{2}{*}{ Unit } & \multicolumn{2}{|c|}{$\begin{array}{l}\text { Position of Unit in } \\
\text { Lithologic Column } \\
\text { (Section, interval in } \mathrm{cm} \text { ) }\end{array}$} & \multirow{2}{*}{$\begin{array}{l}\text { Approx. Depth Interval } \\
\text { (m sub-bottom) }\end{array}$} & \multirow[b]{2}{*}{ Basalt Type } & \multirow[b]{2}{*}{ Description } \\
\hline & From & To & & & \\
\hline 1 & $10-1,7(1)^{\mathrm{a}}$ & $11-1,85(48)$ & $3721-3726$ & 2 & $\begin{array}{l}\text { Sequence of portions of six aphyric basalt cooling units, either } \\
\text { pillows or thin flows }\end{array}$ \\
\hline 2 & $11-1,89(49)$ & $11-3,106(87)$ & $3726-3730^{\mathrm{b}}$ & 2 & $\begin{array}{l}\text { Two aphyric basalt flows with small (unrecovered) pillow zone } \\
\text { between }\end{array}$ \\
\hline 3 & $12-1,1(88)$ & $12-1,90(98)$ & $3730-3733$ & 2 & $\begin{array}{l}\text { Sequence of portions of three aphyric basalt cooling units, } \\
\text { either pillows or thin flows }\end{array}$ \\
\hline 4 & $12-1,92(99)$ & $14-2,144(174)$ & $3733-3745^{b}$ & 2 & Nearly 14-m-thick aphyric basalt flow \\
\hline 5 & $14-2,146(175)$ & $15-3,148(249)$ & $3745-3757$ & 1 & $\begin{array}{l}\text { Sequence of many small plagioclase-olivine phyric basalt } \\
\text { pillows or thin flows }\end{array}$ \\
\hline 6 & $15-4,2(250)$ & $17-2,85(306)$ & $3757-3764$ & 1 & Plagioclase-olivine phyric basalt flow \\
\hline 7 & $17-2,86(307)$ & $17-3,38(318)$ & $3764-3767$ & 1 & Similar to Unit 5 \\
\hline 8 & $17-3,40(319)$ & $18-2,30(353)$ & $3767-3771^{b}$ & 4 & $\begin{array}{l}\text { Sequence of several small plagioclase-olivine clinopyroxene } \\
\text { phyric basalt pillows or thin flows }\end{array}$ \\
\hline 9 & $18-2,32(354)$ & $18-2,133(365)$ & 3771-3777 & 2 & Aphyric basalt pillows or thin flows (only one recovered) \\
\hline 10 & $18-2,135(365)$ & $20-1,42(408)$ & $3777-3786$ & 4 & $\begin{array}{l}\text { Sequence of small plagioclase-clinopyroxene-olivine phyric } \\
\text { basalt pillows or thin flows }\end{array}$ \\
\hline 11 & $20-1,43(409)$ & $20-4,150(480)$ & 3786-3794 & 4 & $\begin{array}{l}\text { Sequence of either large }(1-2 \mathrm{~m}) \text { pillows or alternating small } \\
\text { pillows and thicker flows of plagioclase-clinopyroxene } \\
\text { olivine phyric basalt }\end{array}$ \\
\hline
\end{tabular}

a Numbers in parentheses represent piece numbers.

b Calculated on the assumption that the proportion recovered was representative of the fraction present in the interval cored.

gioclase microphenocrysts (up to $1 \mathrm{~mm}$ ) are more abundant $(5-7 \%)$. The groundmass in the bulk of the rocks recovered consists mostly of spherical, bow-tie, and radial spherulites, but sworls of skeletal plagioclase and groundmass clinopyroxene are present in the coarser samples. Vesicles are small $(<0.5 \mathrm{~mm})$ and rare $(<0.1-$ $1 \%$ ) and filled with bright green or brown and red celadonite or olive green smectite. The rocks are pervasively, moderately altered. Olivine in all thin sections is completely replaced by clay minerals. Glassy margins, in general, are strongly altered, but some glass is preserved in most of them. Cracks are abundant and are usually filled with green or light colored clays. There are oxidized zones along some of the cracks. Red or brown clays and lesser iron hydroxides are present in the cracks, and they are dispersed throughout the rock next to the cracks.

\section{Unit 2 (Core 11, Sections 1-3; Basalt Type 2)}

The material recovered from Unit 2 suggests that this was a single flow about 5 meters thick, but the borehole televiewer indicated that a narrow pillow zone, which was not recovered, lies between two flows that are 2 to 3 meters thick apiece. The interiors of these flows are holocrystalline, with radial or microdoleritic groundmasses. A glassy margin from the topmost flow was recovered in Core 11, Section 1. The bottom portion of the two flows was not recovered, but the bottom of Core 11 is finer grained than the middle of the core, indicating that the flow bottom was near.

\section{Unit 3 (Core 12, Section 1; Basalt Type 2)}

Unit 3 consists of portions of three subaphyric basalt cooling units, either pillow lavas or thin flows. The unit is similar to Unit 1.

\section{Unit 4 (Core 12, Section 1-Core 14, Section 2; Basalt Type 2)}

Unit 4, of which we recovered 6.64 meters, consists entirely of a single flow about 7 meters thick, as revealed by logging and the downhole televiewer. The basalt is similar to the basalts of Units 1 through 3 in the percentages and dimensions of plagioclase, olivine, and clinopyroxene microphenocrysts. The central part of the unit is a holocrystalline subaphyric dolerite. The top and bottom of the flow are fine grained. The rock is massive, but it has a well-developed system of subhorizontal and vertical fractures along which secondary minerals have been deposited. In the upper 2 to 3 meters of the flow, the secondary minerals are mainly green or red clay minerals and iron hydroxides. Zones of alteration parallel the fractures and are stained red and green. With increasing depth in the flow, the abundance and thickness of the cracks decreases, and the cracks are lined with green clay minerals only. The adjacent zones of alteration are narrower and are stained dark greenred staining is absent. At about the point where the alteration zones next to the cracks have thinned to vanishing, calcite joins the crack-lining secondary mineral assemblage, occupying the central portion of the cracks between thin bands of green clays. Here, the cracks are only 1 to $3 \mathrm{~mm}$ wide. At the very bottom of the flow, the crack thickness is very small, but within about $20 \mathrm{~cm}$, the entire sequence described previously is reversed. Calcite disappears, and green clays are associated with reddish clays and iron hydroxides at the very bottom of the flow.

It seems, therefore, that as secondary minerals were deposited from fluids circulating through the flow, and 
as the residual fluids worked their way along an evermore-restricted fracture network, the availability of oxygen diminished, and the maximum solubility of calcite was exceeded. Fluids working their way into the flow from the top penetrated the flow farther than fluids at the bottom. This is related to the way the network of contraction cracks developed as the flow cooled. Heat was lost from the top more quickly than from the bottom; hence downward-growing cracks reached deeper into the flow than upward-growing cracks.

\section{Unit 5 (Core 14, Section 2-Core 15, Section 3; Basalt Type 1)}

Unit 5 consists of many small pillows or thin flows of sparsely to moderately phyric plagioclase-olivine basalt, with accessory chromite phenocrysts but no clinopyroxene phenocrysts and very few vesicles. Spinel (picotite) phenocrysts up to $0.3 \mathrm{~mm}$ occur as megacrysts of plagioclase and as isolated crystals in the groundmass. There are 1 to 2 grains of spinel per thin section, and in one thin section there are 4 grains. Plagioclase phenocrysts are up to $3 \mathrm{~mm}$ in length and make up 5 to $10 \%$ of the rock. Olivine, usually altered to pale clay minerals, is up to $1.5 \mathrm{~mm}$ in size and is 1 to $2 \%$ of the rock. The groundmass ranges from glassy, through spherulitic, to holocrystalline aggregates of acicular radiating plagioclase microlites intergrown with dendritic clinopyroxene and skeletal titanomagnetite. Three partly altered glassy margins were recovered. Alteration in this unit is primarily to green clays, with only rare occurrences of reddish clays and iron hydroxides.

\section{Unit 6 (Core 15, Section 4-Core 17, Section 2; Basalt Type 1)}

Unit 6 is a thick flow of the same type of basalt as in Unit 5. The central part of the flow is holocrystalline, sparsely phyric dolerite with the same percentage of plagioclase, olivine, and spinel phenocrysts as in Unit 5. The groundmass is medium grained and consists of plagioclase $(\sim 45 \%)$, clinopyroxene $(\sim 40 \%)$, altered olivine $(\sim 7-10 \%)$, and titanomagnetite $(\sim 5-7 \%)$. Alteration is similar to that present in Unit 5. Almost colorless smectite replaces olivine. Green clay minerals, Fe-hydroxides, and calcite are rare in the olivine pseudomorphs, but calcite and clays typically fill cracks.

\section{Unit 7 (Core 17, Section 2; Basalt Type 1)}

Unit 7 is made up of sparsely plagioclase-olivine phyric basalt and is completely analogous to Unit 5 . The entire sequence of basalts from Units 5 to 7 may represent an eruptive cycle: pillows, flow, and more pillows, corresponding to the onset, waxing, and waning of the rate of eruption.

\section{Unit 8 (Core 17, Section 3-Core 18, Section 2; Basalt Type 4)}

Unit 8 is made up of moderately phyric pillow basalt, with 10 to $15 \%$ plagioclase phenocrysts, megacrysts, and glomerocrysts; 1 to $2 \%$ clinopyroxene phenocrysts; and 1 to $2 \%$ olivine phenocrysts. The phenocrysts reach $3 \mathrm{~mm}$ in size. Vesicles are almost completely absent. The basalts are very fine grained to spherulitic. Alteration is weak to moderate. Some olivine phenocrysts are still fresh. Olive green smectite is the predominant secondary mineral, lining cracks and replacing olivine. Clays, calcite, and (rarely) aragonite line the cracks.

\section{Unit 9 (Core 18, Section 2; Basalt Type 2)}

Unit 9 is a 1.1 -meter cooling unit of substantially aphyric basalt. The glassy rind at the top of the cooling unit was recovered, and it contained a few phenocrysts of plagioclase and clinopyroxene up to $2 \mathrm{~mm}$ in size. Elsewhere, the microphenocrysts amounted to less than 1 to $2 \%$ of the rock. Chemically, this basalt may simply be an aphyric equivalent of the two more porphyritic basalt types above and below it.

\section{Unit 10 (Core 18, Section 2-Core 19, Section 3; Basalt Type 3)}

Unit 10 is moderately plagioclase-clinopyroxene-olivine phyric basalt; it is analogous to Unit 9 and perhaps equivalent to it chemically. Most rocks are very fine grained to spherulitic. Others are coarser (microdoleritic). Four glassy margins were recovered. Alteration is strong at the glassy margins to the extent that several pieces have interpillow hyaloclastite breccias cemented to them by alteration minerals. Glass and the olivine in or near the glass are completely replaced by clays. The unit consists of pillows or thin flows.

\section{Unit 11 (Core 20; Basalt Type 3)}

Unit 11 is equivalent to Unit 10 (and is very similar to Unit 8) in terms of mineralogy, petrography, and alteration. Glassy margins are strongly altered to olive green smectites and, more rarely, brown celadonite. Six glassy margins were recovered. Other grain-size transitions plus the glass margins indicate that at least 10 cooling units were partially or completely recovered. The distinction between this unit and the one immediately above is based entirely on the occurrence in this unit of two fairly large pillows or thin flows, almost completely recovered, both between 0.75 and 1 meter thick.

\section{Holes 504A and 504B, Leg 69}

During Legs 69 and 70 basement was drilled and recovered from Holes 504A and 504B. Using as criteria phenocryst assemblages, position in the hole, occurrence of cooling units, and rock texture, we divided the basalts of Hole 504B into 49 lithologic units. The basement of Hole 504A, using the same criteria, is formed of a single unit. Several of the units in Hole 504B have been subdivided into subunits according to their main textural features. In this section, we describe the lithologic units and subunits in the order encountered during drilling. Information on the intervals and depths of the units and subunits in Hole 504B is given in Table 6. Figure 4 gives a schematic representation of the lithologic units and shows the correlations in basement lithostratigraphy between Holes 501, 504A, and 504B. Five petrographic types were recognized on the basis of phenocrysts in hand samples visible with a hand lens $(\sim 10 \times)$ : Type 1 , plagioclase-olivine phyric basalt with 
Table 6. Basement lithostratigraphy, Hole 504B.

\begin{tabular}{|c|c|c|c|c|c|c|c|c|}
\hline \multirow[b]{2}{*}{ Unit } & \multirow[b]{2}{*}{$\begin{array}{c}\text { Basalt } \\
\text { Type }\end{array}$} & \multicolumn{3}{|c|}{ Depth of Base of Unit (m) } & \multirow{2}{*}{$\begin{array}{l}\text { Unit } \\
\text { Thick- } \\
\text { ness } \\
\text { (m) }\end{array}$} & \multicolumn{3}{|c|}{$\begin{array}{l}\text { Position of } \\
\text { Base of Unit }\end{array}$} \\
\hline & & $\begin{array}{c}\text { Below } \\
\text { Rig Floor }\end{array}$ & $\begin{array}{c}\text { Sub- } \\
\text { bottom }\end{array}$ & $\begin{array}{c}\text { Sub- } \\
\text { basement }\end{array}$ & & Core & $\begin{array}{l}\text { Sec- } \\
\text { tion }\end{array}$ & $\begin{array}{l}\text { Lev } \\
\text { (en }\end{array}$ \\
\hline (Seafloor) & - & 3473.5 & 0 & - & - & - & - & \\
\hline $\begin{array}{l}\text { (Top of } \\
\text { basement) }\end{array}$ & - & 3746.0 & 274.5 & - & - & - & - & \\
\hline 1 & 2 & 3753.5 & 280.0 & 5.5 & 5.5 & 4 & 1 & \\
\hline $2 \mathrm{~A}$ & 1 & 3776.0 & 302.5 & 28.0 & 22.5 & 6 & 2 & \\
\hline $2 \mathrm{~B}$ & 1 & 3780.0 & 306.5 & 32.0 & 4.0 & 6 & 2 & \\
\hline $2 \mathrm{C}$ & 1 & 3786.5 & 313.0 & 38.5 & 6.5 & 7 & 3 & \\
\hline $2 \mathrm{D}$ & 1 & 3799.8 & 326.3 & 51.8 & 13.3 & 9 & i & \\
\hline $3 \mathrm{~A}$ & 2 & 3841.8 & 368.3 & 93.8 & 42.0 & 13 & 4 & \\
\hline $3 \mathrm{~B}$ & 2 & 3846.7 & 373.2 & 98.7 & 4.9 & 14 & 2 & \\
\hline $3 \mathrm{C}$ & 2 & 3861.6 & 388.1 & 113.8 & 12.9 & 16 & 3 & \\
\hline 4 & 1 & 3871.8 & 398.3 & 723.8 & 10.2 & 18 & I & \\
\hline 5 & 2 & 3881.2 & 407.7 & 132.1 & 9.4 & 19 & 2 & 48 \\
\hline 6 & 3 & 3881.8 & 408.3 & 133.7 & 0.6 & 19 & 2 & $\begin{array}{l}45 \\
80\end{array}$ \\
\hline $\begin{array}{l}7 \\
8\end{array}$ & $\frac{1}{3}$ & $\begin{array}{l}3882.1 \\
38884\end{array}$ & $\begin{array}{l}408.6 \\
414.9\end{array}$ & 134.0 & $\begin{array}{l}0.3 \\
6.3\end{array}$ & $\begin{array}{l}19 \\
20\end{array}$ & 2 & 80 \\
\hline $\begin{array}{l}8 \\
9\end{array}$ & $\begin{array}{l}3 \\
2\end{array}$ & $\begin{array}{l}3888.4 \\
3897.0\end{array}$ & $\begin{array}{l}414.9 \\
423.5\end{array}$ & 14 & $\begin{array}{l}6.3 \\
8.6\end{array}$ & ${ }_{21}^{20}$ & $\frac{1}{2}$ & 40 \\
\hline 10 & 3 & $\begin{array}{l}3898.8 \\
3898\end{array}$ & 425.3 & & $\begin{array}{l}8.6 \\
1.8\end{array}$ & $\begin{array}{l}21 \\
21\end{array}$ & ${ }_{3}^{2}$ & 28 \\
\hline 11 & 2 & 39 & & & 2.1 & 21 & 4 & 28 \\
\hline 12 & 3 & 3901.2 & & & 0.3 & 21 & 4 & 30 \\
\hline 13 & 2 & 3901.7 & 428.2 & & . & 21 & 4 & \\
\hline 14 & 3 & 390 & 429.5 & is & 1.3 & 21 & 5 & 47 \\
\hline 15 & 2 & 3903.2 & 429.7 & 18 & 0.2 & 27 & 5 & 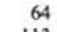 \\
\hline 16 & 3 & 3929.4 & 455.9 & & 26.6 & 24 & 3 & 113 \\
\hline 17 & 2 & 3945.4 & & 19 & 16.0 & 27 & 1 & 125 \\
\hline 18 & 1 & & & & & 28 & 1 & 32 \\
\hline 19 & 3 & 3957.5 & & & & 28 & 5 & 25 \\
\hline 20 & 1 & $\begin{array}{l}3962.5 \\
\text { Vo recove }\end{array}$ & $\begin{array}{l}489.0 \\
3962.5-3\end{array}$ & $\begin{array}{l}214.5 \\
1.0 \mathrm{~m} \text { belor }\end{array}$ & 5.0 & 29 & 2 & 15 \\
\hline (Top of & & $\begin{array}{l}\text { No recove } \\
3981.0\end{array}$ & 507.5 & & & & & \\
\hline nit 21) & $\overline{4}$ & $\begin{array}{l}3981.0 \\
3983.9\end{array}$ & & $\begin{array}{l}233.0 \\
235.9\end{array}$ & 20 & $\bar{n}$ & $\overline{2}$ & \\
\hline 21 & $\begin{array}{l}4 \\
3\end{array}$ & 39 & 510.4 & & 2.9 & 32 & 2 & 12 \\
\hline$\frac{22}{23 \mathrm{~A}}$ & 1 & 01.8 & 528.3 & 253. & 2.4 & $\begin{array}{l}34 \\
34\end{array}$ & 1 & $\begin{array}{r}43 \\
122\end{array}$ \\
\hline $23 \mathrm{~B}$ & I & & & & 7.8 & 35 & 1 & 70 \\
\hline 2 & 3 & & & & 16.4 & 17 & 1 & \\
\hline 2 & 1 & & 571.5 & & 19.0 & 9 & 1 & \\
\hline 2 & 2 & & & & 1.0 & 9 & 2 & \\
\hline 2 & 3 & & & & 16.0 & is & 4 & \\
\hline 28 & 5 & & 61 & & 93.5 & 4 & 1 & 4 \\
\hline $29 \mathrm{~A}$ & 3 & & & & 0. & 4 & i & 132 \\
\hline & 3 & & & & 7 & 15 & i & \\
\hline & 3 & & & & .2 & is & 2 & 48 \\
\hline & 2 & & & & 8 & 47 & 2 & 2 \\
\hline 3 & 2 & & & & 0. & 47 & 2 & \\
\hline 33 & 2 & & & & 7. & 48 & 1 & \\
\hline 3 & Breccia & & & & 0 & 48 & i & 35 \\
\hline 3. & 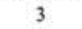 & & & & 1 & 48 & 2 & 110 \\
\hline & 3 & & & & & 49 & 1 & \\
\hline & 3 & & & & 13 & 50 & i & 3 \\
\hline 3. & 3 & & & & 23 & 54 & i & \\
\hline 3 & 2 & & & & & 54 & i & \\
\hline 3 & 3 & & & & 22. & 57 & i & \\
\hline 3 & 2 & & & & 9 & 58 & i & \\
\hline 3 & 3 & & & & & 59 & i & \\
\hline 39 & 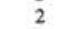 & & & & 2. & 61 & I & \\
\hline 4 & 2 & & 771. & & 21. & 63 & 4 & \\
\hline 41 & 2 & 42 & 772. & 49 & 0. & 63 & 4 & \\
\hline 42 & 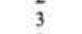 & & 774 & & 2. & 64 & 1 & 40 \\
\hline 43 & 2 & 4 & 776. & 50 & 2.4 & 64 & 3 & \\
\hline 44 & 3 & 425 & 778 & 303 & 1.4 & 64 & 4 & \\
\hline 45 & 3 & 426 & 793. & 518 & 14.8 & 66 & 2 & \\
\hline 46 & 2 & 4273 & 800 & 525 & 7.3 & 67 & i & \\
\hline 47 . & 2 & 70 & 819 & 544 & 18.7 & 69 & 1 & \\
\hline 48 & 2 & & 828.2 & 553.7 & 92 & 70 & i & \\
\hline 49 & 3 & 102.4 & 8.9 & 54.4 & 0.7 & 70 & 2 & \\
\hline
\end{tabular}

essential chromite; Type 2, aphyric and sparsely phyric basalts with variable proportions and occurrences of phenocrysts; Type 3, plagioclase-olivine-clinopyroxene phyric basalt; Type 4 , highly plagioclase-olivine-clinopyroxene phyric basalt; and Type 5 , moderately plagioclase-olivine phyric basalt lacking clinopyroxene and chromite. These types are indicated in Figure 4.

Basement was drilled in Hole 504A for a little over 12 meters, but only $\sim 5.5$ meters were recovered. The recovered rock represents a sequence of pillows and thin massive flows of sparsely phyric, plagioclase-olivine-clinopyroxene basalt. Plagioclase phenocrysts are predominant both in size (up to $3 \mathrm{~mm}$ ) and quantity (about $7 \%$ ). Olivine and augite phenocrysts are a little smaller and form about 2 and $1 \%$ of the rock, respectively. The rock is holocrystalline in the interiors with ophitic or subophitic texture, and variolitic or glassy in the cooling selvages. Vesicles are small and sparse $(<1 \mathrm{~mm}$ and $1 \%$ ). They are filled with green or brown clay minerals. The basalt is moderately altered. All olivine is converted into clay minerals or carbonate. Cracks are filled with these minerals too. Poor recovery did not permit the subdivision of the petrographically uniform basement of Hole 504A into individual pillow and flow units.

The following material describes the 49 lithologic units in Hole 504B.

\section{Unit 1 (274.5-280.0 $\mathrm{m}$ below seafloor [mbsf]; Basalt Type 2)}

Unit 1 is sparsely phyric plagioclase-olivine-augite basalt. Thin, massive flows seem to be predominant, at least in the recovered material. Phenocrysts of plagioclase olivine and augite are small $(<3 \mathrm{~mm})$. Plagioclase is more abundant than olivine and augite. Phenocryst content is 5 to $10 \%$. The augite forms glomerocrysts with plagioclase. Olivine occurs as euhedral grains. Vesicles (1-mm diameter; $\sim 1 \%$ of rock) are round and filled with clay minerals. The groundmass is subophitic and partly spherulitic. Recovered glassy margins are flat. Alteration is moderate and rather uniform. Clay minerals completely replace olivine and fill cracks. Oxidation is rather weak. Some cracks are filled with yellow and red clay minerals.

\section{Unit 2 (280.0-326.3 mbsf; Basalt Type 1)}

Unit 2 is accessory-chromite-bearing moderately phyric pillow and massive flow basalts. We subdivided the unit into four subunits using structural and textural features.

\section{Subunit 2A (280.0-302.5 mbsf)}

Subunit 2A is a sequence of pillows and massive flows of moderately phyric basalts. The rocks are 7 to $10 \%$ euhedral and subhedral glomerocrysts and phenocrysts of plagioclase 4 to $6 \mathrm{~mm}$ across. Euhedral and occasionally subhedral or skeletal olivine phenocrysts up to 4 $\mathrm{mm}$ in size are almost completely altered to green or red clay minerals and locally to calcite. They form 2 to $3 \%$ of the rock. Euhedral or skeletal chromite phenocrysts 0.05 to $0.8 \mathrm{~mm}$ in size occur in the groundmass and are included in phenocrysts of plagioclase and olivine. Usually there are several grains of chromite per thin section.

Small $(<0.5 \mathrm{~mm})$, round vesicles are about $0.5 \%$ of the rock or are absent. Groundmass texture varies from glassy and variolitic at cooling selvages to interstitial and ophitic in interiors. Glassy pillow margins were recovered in 34 samples. Cracks are filled with green and red clay minerals and occasionally with calcite.

\section{Subunit 2B (302.5-306.5 mbsf)}

Subunit 2B is a cooling unit. The upper and the lower margins were recovered. Petrographically the rock is the same as that in Subunit 2A, but two intervals of finegrained aphyric rock are positioned symmetrically in the unit. The intervals are succeeded by rather distinct, sharp transitions to the phyric rocks. In structure, the subunit 


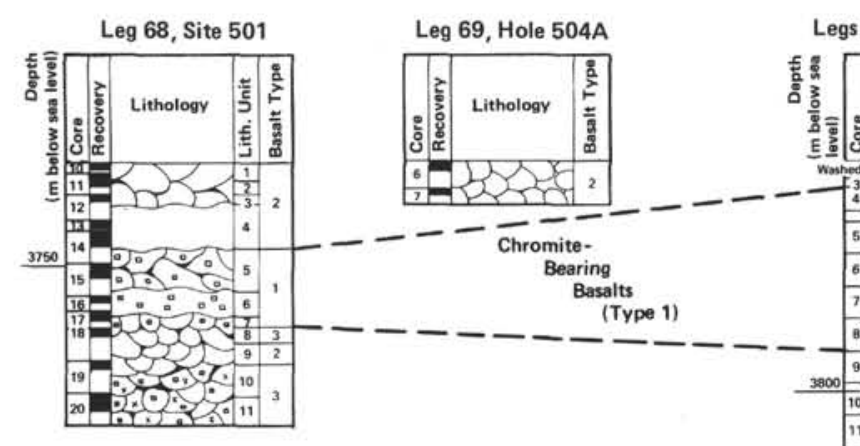

egs 69 and 70, Hole 504B

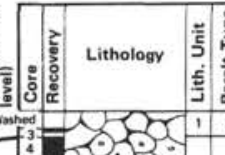

起 
is as follows: (1) upper glassy margin plus crystalline basalt, moderately plagioclase-olivine phyric $-7 \mathrm{~cm}$ recovered; (2) aphyric (microphyric) fine-grained basalt-33 $\mathrm{cm}$ recovered; (3) moderately phyric plagioclase-olivine basalt of a cooling-unit interior-more than $70 \mathrm{~cm}$ recovered; (4) aphyric to microphyric fine-grained basalt$40 \mathrm{~cm}$ recovered; (5) moderately phyric plagioclase-olivine basalt with a lower glassy margin $-20 \mathrm{~cm}$ recovered.

These rocks include intervals which are microphyric fine-grained basalt with microlites of plagioclase, a spherulitic groundmass, and sparse chrome-spinel crystals. These "aphyric" intervals are possibly thin dykes or injections into solid but hot massive flow interiors.

\section{Subunit 2C (306.5-313.0 mbsf)}

Subunit $2 \mathrm{C}$ is a sequence of massive flows and pillows. Petrographically it is similar to the basalts of Subunit $2 \mathrm{~A}$, but thin flows appear to be predominant. Glassy margins were recovered from 18 samples; 12 of them are flat.

\section{Subunit 2D (313.0-326.3 mbsf)}

Subunit 2D is a sequence of sparsely to moderately phyric basalt flows. Phenocryst content varies from 5 to $10 \%$ of the rock. There is three times as much plagioclase as olivine. The phenocrysts are mostly euhedral, but there are a few skeletal olivine phenocrysts and plagioclase glomerocrysts. The groundmass is variolitic near the cooling selvages, but deeper into the flows it consists of plagioclase microlites in a spherulitic mesostasis. The flow interiors are rather coarse grained and are ophitic in texture. The phenocrysts in the coarse interiors are two to three times as large as those of the grains in the groundmass. Because of this the rock looks aphyric megascopically. Vesicles are generally absent, but in thin section small cavities can occasionally be seen. Subunit 2D appears to consist of two massive flows; their junction is in Core 8 , Section 1 , as seen by a glassy margin and associated grain-size changes.

\section{Unit 3 (326.3-388.1 mbsf; Basalt Type 2)}

Unit 3 is a sequence of sparsely phyric (megascopically aphyric) plagioclase-olivine basalt pillows and massive flows, with rare augite phenocrysts. Plagioclase phenocrysts are 2 to 3 times as common as those of olivine. Clinopyroxene phenocrysts ( 3 to 7 per thin section) are generally smaller. Olivine and a few plagioclase phenocrysts are euhedral. Most of the plagioclase and augite forms glomerocrysts. The groundmass varies from glassy to ophitic, depending on its position on cooling units. Alteration is weak to moderate. Pillows predominate in the upper part of the unit; massive flows, toward its base. We have divided the unit into three subunits.

\section{Subunit 3A (326.3-368.3 mbsf)}

Subunit $3 \mathrm{~A}$ is a sequence of pillows and massive flows. A number of glassy margins were recovered; most were pillow selvages. In Core 10, Section 1, highly fractured and brecciated rocks $(18 \mathrm{~cm})$ were recovered. Calcite occurs in cracks in the upper part of the subunit, whereas red clays and oxidation zones predominate at the base.
There are thicker flows or pillows in the lower part of the subunit.

\section{Subunit 3B (368.3-373.2 mbsf)}

Subunit $3 \mathrm{~B}$ is a pillow and thin flow sequence composed of plagioclase-olivine phyric basalt. Augite and chromite phenocrysts are absent. Glassy margins were recovered from six specimens. Green and red clay minerals replace olivine and fill cracks.

\section{Subunit 3C (372.0-388.1 mbsf)}

Subunit $3 \mathrm{C}$ is a sequence of pillows and flows similar to Subunit 3A. Glassy margins (mostly pillow) were recovered in 19 samples. Alteration is moderate. Green or red clay minerals replace olivine and fill cracks. Calcite is rare or absent.

\section{Unit 4 (388.1-398.3 mbsf; Basalt Type 1)}

Unit 4 is a sequence of pillows and flows of moderately to sparsely phyric plagioclase-olivine basalt with accessory chromite. Phenocrysts of augite are absent. Petrographically, the unit is similar to Unit 2.

These basalts contain euhedral plagioclase phenocrysts and glomerocrysts. The size of the phenocrysts can differ from rock to rock, varying from 2 to $3 \mathrm{~mm}$ at one to 4 to $7 \mathrm{~mm}$ at another. The phenocryst concentration is 7 to $10 \%$. Euhedral or skeletal olivine up to 3 to $4 \mathrm{~mm}$ forms about $3 \%$ of the rock. Chromite can be euhedral or skeletal, with a grain size of 0.1 to $0.7 \mathrm{~mm}$. There are several grains per thin section. The groundmass is glassy or variolitic at cooling selvages and interstitial to ophitic in flow interiors. Glassy margins were recovered in 18 samples. They are mostly flat. Pillows are predominant in the upper part of the unit. Alteration is moderate, with red and green clay minerals filling cracks and replacing olivine. Calcite in veins and olivine pseudomorphs is more rare.

\section{Unit 5 (398.3-407.7 mbsf; Basalt Type 2)}

Unit 5 is a sequence of pillows and thin massive flows of sparsely phyric, plagioclase-olivine basalt. Phenocrysts of plagioclase and olivine, 2 to $4 \mathrm{~mm}$ in size, are mostly euhedral. They constitute 5 to $7 \%$ and 2 to $3 \%$ of the rocks, respectively. Augite phenocrysts are absent. Fine euhedral chromite crystals were found in one of the thin sections. The groundmass consists of plagioclase microlites and spherulitic mesostasis near cooling selvages. In holocrystalline interiors the groundmass is ophitic. Vesicles up to $1 \mathrm{~mm}$ in diameter constitute $\sim 1 \%$ of the rocks and occur mainly in the upper part of the unit. Alteration is moderate. Secondary minerals are green and red clay, and Fe-hydroxides replace olivine and fill cracks and vesicles. Calcite is almost absent. Massive flows appear to be predominant, at least at the base of the unit. Only one glassy (pillow) margin was recovered.

\section{Unit 6 (407.7-408.3 mbsf; Basalt Type 3)}

Unit 6 is moderately phyric plagioclase-olivine-augite basalt. The phenocryst content is about $7 \%$ plagioclase, $3 \%$ olivine, and $1 \%$ clinopyroxene. The ground- 
mass is holocrystalline and microlitic. Vesicles are absent. A breccia with fragments of this rock and green smectite cement was recovered from the central part of the unit. Smectite also forms olivine pseudomorphs and fills cracks.

\section{Unit 7 (408.3-408.6 mbsf; Basalt Type 1)}

Unit 7 is fine-grained, sparsely phyric (microphyric) basalt with small phenocrysts of plagioclase, olivine, and accessory chromite. The rock is petrographically similar to Unit 5 and may be a dike.

\section{Unit 8 (408.6-414.9 mbsf; Basalt Type 3)}

Unit 8 is a moderately phyric plagioclase-olivineaugite basalt which appears to be a continuation of the basalts of Unit 6 crossed by the basalt dike(?) of Unit 7 . This unit is mainly a pillow sequence: six specimens of glassy pillow margins were recovered from it.

\section{Unit 9 (414.9-423.5 mbsf; Basalt Type 2)}

Unit 9 is an aphyric (microphyric) basalt flow. Plagioclase phenocrysts (about $5 \%$ ) are euhedral or form glomerocrysts; grain size is 2 to $3 \mathrm{~mm}$. The rock is holocrystalline with ophitic texture. Cooling selvages were not recovered. Almost all of the samples recovered demonstrate oxidation zonality in secondary clay minerals. In addition, calcite occurs in the central parts of the crack fillings.

\section{Unit 10 (423.5-425.3 mbsf; Basalt Type 3)}

Unit 10 is moderately phyric basalt, with plagioclase, augite, and olivine phenocrysts. The grain size of the phenocrysts is 3 to $5 \mathrm{~mm}$. The plagioclase and augite are mainly in glomerocrysts, and the olivine is in single euhedral grains. The plagioclase and clinopyroxene phenocrysts contents are approximately $5 \%$ each; olivine is $3 \%$. The groundmass is mainly variolitic, with about $10 \%$ plagioclase microlites. The unit represents a thin flow or a dike with the lower glassy margin recovered. The rock is highly fractured. Alteration is moderate. Green smectite is the principal secondary mineral.

\section{Unit 11 (425.3-427.4 mbsf; Basalt Type 2)}

Unit 11 is an almost aphyric (sparsely microphyric) plagioclase-olivine basalt flow. Sparse phenocrysts of plagioclase (about $5 \%$ ) and olivine $(<1 \%)$ range in size up to 3 and $2 \mathrm{~mm}$, respectively. The texture of the groundmass varies from variolitic to ophitic. Alteration is locally rather strong. Dark gray smectite, a red clay mineral, and iron hydroxide partly replace the variolitic groundmass. The rock is highly fractured. Cooling selvages were not recovered.

\section{Unit 12 (427.4-427.7 mbsf; Basalt Type 3)}

The type of rock in Unit 12 is the same as that in Unit 10 : moderately phyric basalt with phenocrysts of plagioclase, augite, and olivine.

\section{Unit 13 (427.7-428.2 mbsf; Basalt Type 2)}

Unit 13 is an almost aphyric pillow basalt, with small plagioclase and olivine phenocrysts $(2-3 \mathrm{~mm})$. The phe- nocryst content is about $5 \%$ plagioclase and 2 to $3 \%$ olivine. The groundmass is glassy, variolitic, or microlitic, with a spherulitic mesostasis. Glassy margins were recovered in four specimens, but they may have come from a single pillow. The rock is rather fresh, with green smectite replacing olivine and filling cracks. Petrographically the rock is similar to Units 9 and 11.

\section{Unit 14 (428.2-429.5 mbsf; Basalt Type 3)}

Unit 14 is moderately phyric basalt with phenocrysts of plagioclase (about $5 \%$ ), augite (about $5 \%$ ), and olivine (about 3\%). Petrographically the rock is the same as that in Units 10 and 12 (Type 3). The unit appears to represent flows. Three recovered glassy margins are flat. The rock is rather fresh. Olivine is partly altered to smectite and calcite.

\section{Unit 15 (429.5-429.7 mbsf; Basalt Type 2)}

Unit 15 is a thin interval (possibly a dike) of finegrained megascopically aphyric basalt. Microphenocrysts of plagioclase and olivine (5-7\% and $2-3 \%$, respectively) are mainly euhedral. The grain size for both is 0.5 to $1.5 \mathrm{~mm}$. Accessory-chromite grains are much smaller $(\sim 0.1 \mathrm{~mm})$. The groundmass is microlitic (plagioclase), with a spherulitic mesostasis. Petrographically the unit is similar to Unit 7.

\section{Unit 16 (429.7-455.9 mbsf; Basalt Type 3)}

Unit 16 is a pillow and possibly massive flow sequence of moderately phyric, plagioclase-olivine-augite basalts. Petrographically the rock is similar to that in Units 10 and 12 . The phenocryst grain size is 2 to $5 \mathrm{~mm}$. Most of the phenocrysts are euhedral, but the augite phenocrysts in the upper part of the unit are a little rounded and usually twinned. The augite in the lower part of the unit, where it is a little more abundant, forms euhedral phenocrysts and glomerocrysts with and without plagioclase. The average abundance of augite phenocrysts is 1 to $2 \%$; of plagioclase phenocrysts, $10 \%$; and of olivine phenocrysts, 3 to $4 \%$. The groundmass is mainly variolitic, with 10 to $15 \%$ of plagioclase microliths. Vesicles are almost absent. Glassy pillow margins were recovered in 33 samples. The rock is fractured, pillows usually strongly so. Alteration (clay minerals) is moderate.

\section{Unit 17 (455.9-471.9 mbsf; Basalt Type 2)}

Unit 17 is a massive flow sequence of megascopically aphyric (microphyric) plagioclase-clinopyroxene-olivine basalts. Microphenocrysts of these minerals reach $2 \mathrm{~mm}$ in size. The rock is about $4 \%$ plagioclase (mainly glomerocrysts), $3 \%$ augite (glomerocrysts), and $1 \%$ olivine (euhedral). Vesicles are almost absent. The groundmass is glassy or variolitic, with some plagioclase microlites near cooling selvages, and it is ophitic in flow interiors. Ten glassy margins were recovered, several of them flat. Alteration is moderate and locally strong. Bright green and red clay minerals are rather abundant.

\section{Unit 18 (471.9-475.5 mbsf; Basalt Type 1)}

Unit 18 is sparsely phyric plagioclase-olivine basalt (possibly a dike) with accessory chromite. The rock is 
petrographically similar to Units 2 and 4 . Phenocryst size is 2 to $5 \mathrm{~mm}$ ( $\sim 7 \%$ plagioclase, $2-3 \%$ olivine). The groundmass is microlitic with a spherulitic mesostasis. The rock is moderately altered. Secondary minerals (green and red clay) replace olivine completely or partly and fill cracks. Only one glassy margin was recovered; it was at the very end of the unit.

\section{Unit 19 (475.5-484.0 mbsf; Basalt Type 3)}

Unit 19 is a sequence of pillows and flows of sparsely phyric basalts. Plagioclase, olivine, and augite phenocrysts are euhedral, subhedral, and anhedral (in glomerocrysts). The content and grain size of plagioclase are 5 to $7 \%$ and 3 to $5 \mathrm{~mm}$; of olivine, $3 \%$ and 2 to $4 \mathrm{~mm}$; and of augite, $1 \%$ (in the upper part of the unit) to $3 \%$ (at its end) and 2 to $3 \mathrm{~mm}$. The groundmass is glassy or variolitic at cooling selvages and coarse grained and ophitic in interiors of cooling units. Glassy margins were recovered in 8 specimens. They are flat or curved. The rock is highly fractured and locally brecciated. Alteration is moderate. Red and green clay minerals fill cracks and replace olivine. The red mineral is predominant in the upper part of the unit. Calcite occurs here as well.

\section{Unit 20 (484.0-489.0 mbsf; Basalt Type 2)}

Unit 20 consists of aphyric holocrystalline basalt. Sparse plagioclase and olivine phenocrysts (about 1\%) are mostly euhedral. Their size $(2-4 \mathrm{~mm})$ is only 2 to 3 times as high as the grain size of the groundmass. The texture is ophitic. The rock is fractured and brecciated. Breccia samples were recovered from the upper part of the unit. They consist of aphyric basalt fragments and green smectite cement.

\section{Hole 504B, Leg 70}

Twenty-nine lithologic units were defined for the 347 meters of basement cored in Hole 504B during Leg 70, bringing the total number of lithologic units to 49 . Because of the sometimes poor recovery (average recovery was $26.4 \%$, with less than $10 \%$ in five cores and 10 $20 \%$ in 11 others), it was sometimes difficult to determine the proper location for the boundary between different units. Further, the lithologic units do not necessarily correspond to the geochemistry of the basalt; rather, they represent a tentative division that reflects the recovered material. There was a break in recovery between the portions of the hole cored on Legs 69 and 70 corresponding to Cores 30 and 31 (see Operations).

\section{Unit 21 (507.5-510.4 mbsf; Basalt Type 4)}

Unit 21 consists of several thin lava flows separated by glassy rims on the top or bottom of oriented rock pieces. The flows are spinel-bearing, highly olivine-plagioclase-clinopyroxene phyric basalts. They are medium grained and display subglomerophyric textures. The phenocryst content is high (greater than 40\%); the proportions among the various kinds of phenocrysts are variable. The phenocrysts vary in size, with those of olivine less than $4 \mathrm{~mm}$, those of plagioclase less than 3 $\mathrm{mm}$, and those of clinopyroxene less than $5 \mathrm{~mm}$. Plagioclase and clinopyroxene are subhedral to anhedral and often intergrown; olivine is euhedral. The groundmass exhibits mature sheaf textures and is variolitic in glassy margins. The basalts are partly fractured, and the fractures are filled with smectites and $\mathrm{Fe}$-oxides. Thus, alteration is oxidative. Olivine is replaced by smectite and hematite.

\section{Unit 22 (510.4-525.9 mbsf; Basalt Type 3)}

Unit 22 consists of two flows which are separated at 517.5 meters by a possible dike. The basalt flows are fine- to medium-grained, highly plagioclase-olivine phyric basalts. Euhedral olivine crystals are up to $1.2 \mathrm{~mm}$ in size, euhedral plagioclase laths less than $1.2 \mathrm{~mm}$ in length. Rock texture ranges from hyalo-ophitic to ophitic. The appearance of the rock is massive; alteration is moderate and appears to be oxidative. Olivine is completely replaced by iron hydroxides and clay minerals.

The dike consists of fine-grained variolitic basalt, with glassy rims on the sides of oriented rock pieces.

\section{Unit 23 (525.9-536.1 mbsf, Basalt Type 1)}

Unit 23 is divided into Subunits $23 \mathrm{~A}$ and 23B. It is made up of pillows and thin flows.

\section{Subunit 23A (525.9-528.3 mbsf)}

In Subunit 23A glassy margins are abundant, and they occur at the top, bottom, or sides of many rock pieces. The basalts are spinel bearing and highly plagioclase-olivine phyric. They display a medium-grained, hyalo-ophitic texture. Fine-grained rocks with glassy to variolitic texture occur near and next to the glassy margins. Olivine is euhedral (less than $0.8 \mathrm{~mm}$ ) and partly replaced by smectite. Subhedral plagioclase laths are up to $1.2 \mathrm{~mm}$ in length. The groundmass shows a mature sheaf texture and is partly replaced by iron hydroxides. The alteration is oxidative.

\section{Subunit 23B (528.3-536.1 mbsf)}

Subunit 23B is similar to Subunit 23A in that it consists of pillows and thin flows; it is distinguished from the former because of its finer grain size. Subunit 23B is only aphyric to sparsely phyric. The rocks are more altered than those in Subunit 23A.

\section{Unit 24 (536.1-552.5 mbsf; Basalt Type 3)}

Unit 24 is a massive flow made up of sparsely to moderately plagioclase-clinopyroxene-olivine phyric basalt. The phenocrysts are subhedral plagioclase laths (less than $1.5 \mathrm{~mm}$ in length), subhedral clinopyroxene $(<0.5$ $\mathrm{mm})$, and euhedral to subhedral olivine $(<0.25 \mathrm{~mm})$. The texture is subophitic to intersertal and medium to coarse grained. Alteration is only slight and oxidative. Pyrite occurs as veinlets and scattered grains.

\section{Unit 25 (552.5-571.5 mbsf; Basalt Type 1)}

Unit 25 is a sequence of highly fractured pillows and flows. Numerous glassy margins occur at the top, bottom, and sides of oriented samples. Flow breccia occurs near the top and bottom of the unit. The basalt is fine to medium grained, sparsely to moderately plagioclaseolivine-clinopyroxene phyric. Accessory spinel occurs 
in one sample near the bottom of the sequence (Piece 462). The rock texture is hyalo-ophitic to slightly intersertal. The groundmass has immature and mature sheaf texture. Olivine is euhedral $(<1.7 \mathrm{~mm})$ and totally replaced by smectite. Subhedral or euhedral plagioclase laths $(<1.1 \mathrm{~mm})$ and anhedral to subhedral clinopyroxenes are often gathered in clusters. The alteration is oxidative.

\section{Unit 26 (571.5-572.5 mbsf; Basalt Type 2)}

Unit 26 is massive basalt with a flow breccia at the top. It is medium grained, sparsely plagioclase-olivine phyric basalt, intersertal in texture, with anhedral olivine phenocrysts greater than $0.35 \mathrm{~mm}$ and blocky plagioclase phenocrysts greater than $1 \mathrm{~mm}$. Smectites replace olivine and glass.

\section{Unit 27 (572.5-588.5 mbsf; Basalt Type 3)}

Unit 27 is a massive flow with a grain size that changes from fine (at the top and bottom) to medium to coarse (towards the center). It is made up of moderately plagioclase-olivine-clinopyroxene phyric basalt. Euhedral olivine (less than $1.5 \mathrm{~mm}$ ) and some zoned subhedral plagioclase laths (less than $2.5 \mathrm{~mm}$ ) are always present, but subhedral to anhedral, sometimes twinned clinopyroxene (less than $1 \mathrm{~mm}$ ) is only present in some of the thin sections. The rock texture is ophitic to intersertal. Alteration is either nonoxidative or a slightly oxidative. Pyrite is common at the bottom of the unit.

\section{Unit 28 (588.5-612.0 mbsf; Basalt Type 5)}

Unit 28 consists of fine- to medium-grained, sparsely to moderately plagioclase-clinopyroxene phyric basalt flows. Subhedral plagioclase laths are less than $1.2 \mathrm{~mm}$ in length, clinopyroxene is anhedral to euhedral (less than $1 \mathrm{~mm}$ ). Glassy margins occur at the top, bottom, and center of pieces; breccia occurs at the top and center. Oxidative alteration occurs at the top and bottom of this unit, as shown by the presence of iron hydroxides.

\section{Unit 29 (612.0-621.2 mbsf; Basalt Type 3)}

Unit 29 is made up of highly fractured pillows and flows, with small glomerophyric flows at the top and bottom. We have divided the unit into three subunits.

\section{Subunit 29A (612.0-612.5 mbsf)}

Subunit $29 \mathrm{~A}$ is a small subunit of fine- to mediumgrained glomerophyric basalt. Green clinopyroxene can be observed in hand specimen. Small cracks are coated with smectites.

\section{Subunit 29B (612.5-620.0 mbsf)}

Subunit 29B consists of pillows and thin flows with breccias and glassy margins. The basalt is fine to medium grained, moderately plagioclase-clinopyroxene-olivine phyric, and has hyalopilitic textures. Euhedral olivine $(<0.6 \mathrm{~mm})$ is replaced by smectite. There are also plagioclase laths $(<0.9 \mathrm{~mm})$ and subhedral clinopyroxenes $(<0.8 \mathrm{~mm})$. The groundmass has a mature sheaf texture and is partly replaced by smectites. Pyrite occurs in veins. Some of the alteration was nonoxidative; a slightly oxidative stage followed by the formation of pyrite was also in evidence.

\section{Subunit 29C (620.0-621.2 mbsf)}

Subunit $29 \mathrm{C}$ is a small glomerophyric basalt flow. Green clinopyroxene occurs in hand specimen. Small cracks are coated with smectites.

\section{Unit 30 (621.2-647.7 mbsf; Basalt Type 2)}

Unit 30 is made up of pillows and flows which are highly fractured in some parts. We have divided the unit into three subunits.

\section{Subunit 30A (621.2-639.8 mbsf)}

Subunit $30 \mathrm{~A}$ is a sequence of pillows and flows. Breccias and glassy rims are common in the upper part of the subunit. Two flows are separated by glassy margins in the lower part. The basalts are medium grained, moderately plagioclase-olivine-clinopyroxene phyric, and contain accessory spinel. They are hyalo-ophitic. Subhedral olivine $(<0.6 \mathrm{~mm})$ is completely replaced by smectite. Plagioclase forms subhedral to euhedral zoned laths $(<1.5 \mathrm{~m})$; clinopyroxene is subhedral and sometimes twinned $(<1.5 \mathrm{~mm})$. The groundmass exhibits mature to immature sheaf texture and is partly replaced by smectite. Numerous fractures are filled with green smectite; pyrite occurs as small patches $(<0.5 \mathrm{~mm})$ in some of the fractures. The alteration was nonoxidative.

\section{Subunit 30B (639.8-640.2 mbsf)}

Subunit 30B is a poorly recovered rubble of thin flows. The basalts are highly plagioclase-clinopyroxene-olivine phyric, with glassy margins on every piece. They are fine grained, displaying subglomerophyric and subvariolitic textures. The glassy rims are completely altered to green smectite. Olivine is replaced by smectite.

\section{Subunit 30C (640.2-647.7 mbsf)}

In the upper half of Subunit $30 \mathrm{C}$ there is a highly plagioclase-clinopyroxene-olivine phyric basalt flow, and in the lower half there is a sparsely plagioclase-clinopyroxene-olivine phyric basalt flow. The rock is highly fractured in the upper part and slightly to moderately fractured in the lower part. The basalt is medium grained, displaying subglomerophyric texture with intersertal groundmass in the upper flow; in the lower flow it is hyalopilitic with intersertal groundmass. Plagioclase $(<1.6 \mathrm{~mm})$ forms subhedral laths, and clinopyroxene is euhedral $(<1.6 \mathrm{~mm})$. Euhedral olivine $(<0.3$ $\mathrm{mm}$ ) is completely replaced by smectite. The fractures are filled with green smectite and abundant pyrite. The alteration is nonoxidative.

\section{Unit 31 (647.7-648.3 mbsf; breccia)}

Unit 31 is made up of basalt breccia. The breccia consists of angular to subangular basalt fragments $1 \mathrm{~mm}$ to $1 \mathrm{~cm}$ in diameter in a matrix of green smectite.

\section{Unit 32 (648.3-649.5 mbsf; Basalt Type 3)}

Unit 32 is a massive basalt flow made up of finegrained, sparsely to moderately plagioclase-clinopyrox- 
ene-olivine phyric basalt. It has hyalo-ophitic texture with mature sheafs in the groundmass. Subhedral plagioclase $(<0.9 \mathrm{~mm})$ and clinopyroxene $(<1.3 \mathrm{~mm})$ phenocrysts have rounded corners. Alteration consists of the incomplete replacement of olivine by smectite and the filling of fractures with green smectite and pyrite. It is nonoxidative.

\section{Unit 33 (649.5-669.0 mbsf; Basalt Type 3)}

Unit 33 is a unit of pillows and flows with numerous glassy margins. The unit consists of two subunits.

\section{Subunit 33A (649.5-656.0 mbsf)}

Subunit $33 \mathrm{~A}$ is a pillow sequence, with possibly one small flow in the middle of the unit. Glassy margins occur at the top, bottom, and sides of oriented rock pieces. The basalt is fine to medium grained, aphyric to plagioclase-clinopyroxene-olivine phyric with hyalo-ophitic to variolitic texture. Blocky plagioclase phenocrysts $(<1.5$ $\mathrm{mm}$ ) are most common. Clinopyroxene phenocrysts (rare, $<1.5 \mathrm{~mm}$ ) are also blocky. Euhedral olivine (rare, $<0.2 \mathrm{~mm}$ ) is replaced by smectite. The alteration is oxidative in the upper part, as indicated by the presence of Fe-oxides, and nonoxidative in the lower part. The fractures are filled with green smectite and minor zeolite. In addition, pyrite occurs in the lower part.

\section{Subunit 33B (656.0-669.0 mbsf)}

In terms of petrology, Subunit 33B is very similar to Subunit 33A, but the basalts are more or less brecciated. Smectite and pyrite occur as fracture fillings; therefore the alteration is mostly nonoxidative. It is oxidative at the bottom of the unit, as indicated by the presence of Fe-oxides.

\section{Unit 34 (669.0-692.0 mbsf)}

Unit 34 is massive, coarse-grained ophitic basalt, with a glassy margin on the top. Plagioclase forms subhedral laths $(0.03-1.5 \mathrm{~mm})$, and clinopyroxene is anhedral $(0.08-1.2 \mathrm{~mm})$. Euhedral olivine $(0.08-0.7 \mathrm{~mm})$ is completely replaced by green smectite. Glass amounts to up to $10 \%$ of the interior of the flow; it is completely replaced by smectite. Skeletal magnetite $(0.04 \mathrm{~mm})$ occurs in this glassy area. The texture is ophitic to intersertal. Veins are filled with smectite and pyrite; the alteration is nonoxidative.

\section{Unit 35 (692.0-692.7 mbsf; Basalt Type 2)}

Unit 35 is an interval of fine-grained aphyric basalt displaying hyalo-ophitic texture.

\section{Unit 36 (692.7-715.2 mbsf; Basalt Type 3)}

Unit 36 consists of several basalt flows that are separated from each other by glassy margins. The rocks are fine- to medium-grained aphyric vesicular basalts with hyalo-ophitic to hyalopilitic texture. The groundmass has a mature sheaf texture. Vesicles 0.1 to $0.3 \mathrm{~cm}$ in diameter are scattered through the rock and constitute about $5 \%$ of it. They are empty in the fresh parts, coated or filled with green smectite in the altered parts. Fractures are filled with dark green smectite and pyrite.

\section{Unit 37 (715.2-724.3 mbsf; Basalt Type 2)}

Unit 37 is a slightly fractured, medium- to coarsegrained, sparsely olivine phyric basalt. The texture is subophitic to intergranular with some intersertal areas. The only phenocryst is subhedral olivine $(<1.2 \mathrm{~mm})$, which is completely replaced by smectite. Fractures and veinlets are filled with smectite and pyrite.

\section{Unit 38 (724.3-732.5 mbsf; Basalt Type 3)}

Unit 38 is coarse-grained subophitic basalt and is probably a dike. The upper contact of the dike is weil documented; one oriented rock piece shows a glassy margin with a 2 -cm-thick fragment of the overlying unit as an inclusion next to the glassy margin. A gradual increase in grain size can be observed toward the center of the dike. The lower contact was not recovered. The basalt has ophitic to intergranular texture. Phenocrysts are euhedral olivine $(0.5-0.7 \mathrm{~mm})$, subhedral plagioclase (0.15-0.9 mm), and subhedral clinopyroxene (0.04-2 $\mathrm{mm}$ ). Olivine is completely replaced by smectite. Veinlets are filled with dark green smectite and pyrite. The alteration is nonoxidative.

\section{Unit 39 (732.5-750.5 mbsf; Basalt Type 2)}

Unit 39 consists of a medium-grained, aphyric to moderately plagioclase-olivine phyric basalt. Some brecciated pieces were observed in the upper part. Plagioclase forms subhedral laths $(<0.4 \mathrm{~mm})$, which are often grouped in clumps. Euhedral olivine $(<1.6 \mathrm{~mm})$ is completely replaced by yellow green smectite. Green smectite occurs as a fracture filling together with pyrite. The alteration is nonoxidative.

\section{Unit 40 (750.5-771.6 mbsf; Basalt Type 2)}

Unit 40 consists of pillows and flows which are separated by glassy margins. The rocks are moderately to highly fractured, fine to medium grained. They are moderately plagioclase-olivine phyric basalts displaying hyaloophitic texture. Phenocrysts are euhedral olivine $(<1.0$ $\mathrm{mm})$ and subhedral plagioclase laths $(<1.3 \mathrm{~mm})$. The groundmass has a mature sheaf texture. Green smectite completely replaces olivine and glass; fractures are filled with smectite and some pyrite. The alteration is nonoxidative.

\section{Unit 41 (771.6-772.4 mbsf; Basalt Type 2)}

Unit 41 is a small unit of massive, medium- to coarsegrained, highly plagioclase-olivine phyric basalt with subophitic to intersertal texture. Plagioclase forms subhedral laths $(<1.2 \mathrm{~mm})$. Euhedral olivine $(<0.6 \mathrm{~mm})$ is completely replaced by green smectite. The alteration is moderate and nonoxidative, and veinlets are filled with smectite.

\section{Unit 42 (772.4-774.4 mbsf; Basalt Type 3)}

Unit 42 consists of highly fractured pillows; glassy margins at the top, bottom, and sides of oriented rock pieces are common. The basalt is fine grained, moderately olivine-plagioclase phyric. Alteration is moderate to high. Fractures are filled with green smectite; some 
fractures are up to $10 \mathrm{~mm}$ thick, giving the rock a brecciated appearance. Iron hydroxides occur in some fractures, and pyrite is common toward the bottom of the unit, where it occurs together with iron hydroxides.

\section{Unit 43 (774.4-776.8 mbsf; Basalt Type 2)}

Unit 43 is a unit of a massive, fine- to medium-grained aphyric basalt with hyalo-ophitic texture. The groundmass has a mature sheaf texture. Toward the bottom of the unit the rocks are more fractured and brecciated, with fewer glassy margins. Smectite fills fractures and replaces the groundmass. Pyrite is common, sometimes forming aggregates up to $3 \mathrm{~mm}$ in size. The alteration is nonoxidative.

\section{Unit 44 (776.8-778.2 mbsf; Basalt Type 3)}

Unit 44 consists of massive, coarse-grained, highly plagioclase-pyroxene phyric basalt with subophitic to intersertal texture. Plagioclase $(<1.2 \mathrm{~mm})$ forms subhedral laths, and clinopyroxene $(<1.2 \mathrm{~mm})$ is anhedral. Smectite completely replaces glass and olivine and occurs as a fracture filling. Pyrite occurs in some veins. The alteration is nonoxidative.

\section{Unit 45 (778.2-793.0 mbsf; Basalt Type 3)}

Unit 45 consists of highly fractured, fine- to mediumgrained, highly plagioclase-olivine-clinopyroxene phyric basalt pillows and thin flows. Glassy margins and brecciated basalts are numerous. The basalts have hyaloophitic to hyalopilitic texture; the groundmass has a mature sheaf texture. The phenocrysts are euhedral olivine $(<0.7 \mathrm{~mm})$, euhedral, lathy plagioclase $(<1.2 \mathrm{~mm})$, and subhedral clinopyroxene $(<3 \mathrm{~mm})$. Fractures are numerous and filled with green smectite.

\section{Unit 46 (793.0-800.3 mbsf; Basalt Type 2)}

Unit 46 is a unit of massive medium-grained aphyric basalt with subophitic to intersertal texture. The groundmass consists of olivine-plagioclase-clinopyroxene and titanomagnetite microphenocrysts. About $10 \%$ glass occurs in the groundmass, completely replaced by green smectite. Fractures are filled with smectite, a yellow brown material, and scattered clots and clusters of pyrite crystals.

\section{Unit 47 (800.3-819.0 mbsf; Basalt Type 2)}

Unit 47 consists mostly of fractured, fine- to mediumgrained aphyric to sparsely olivine-clinopyroxene phyric basalt. The texture is hyalopilitic to hyalo-ophitic or subophitic to intersertal. Because of the poor recovery in Cores 67 to 69, it is not possible to subdivide this unit, although there are differences in grain size and appearance in hand specimens. Veinlets are filled with smectite, zeolite, and pyrite.

\section{Unit 48 (819.0-828.2 mbsf; Basalt Type 2)}

Unit 48 consists of fine- to medium-grained, moderately plagioclase-olivine-clinopyroxene phyric basalt with intergranular texture. Euhedral olivine $(<0.7 \mathrm{~mm})$ is partly replaced by smectite; euhedral plagioclase laths $(<0.8 \mathrm{~mm})$ and subhedral clinopyroxene $(<0.4 \mathrm{~mm})$ are the other phenocrysts. Smectite completely replaces glass and fills veinlets.

\section{Unit 49 (828.2-828.9 mbsf; Basalt Type 3)}

Unit 49 is fairly massive, coarse-grained, ophitic basalt. The mineralogy consists of $8 \%$ subhedral olivine $(<2.0 \mathrm{~mm})$ completely replaced by dirty green smectite, $40 \%$ euhedral plagioclase laths $(<1.2 \mathrm{~mm})$, and $40 \%$ anhedral clinopyroxene $(<1 \mathrm{~mm}) ; 5 \%$ skeletal or microlitic titanomagnetite $(<0.08 \mathrm{~mm})$ occurs in some glassy areas. The glass forms about $7 \%$ of the rock. Alteration consists of smectite replacing glass and occurring as a fracture filling, together with zeolite.

\section{BASEMENT IGNEOUS PETROGRAPHY}

\section{Hole 504A}

The basaltic basement recovered from Hole 504A belongs to a single petrographic unit identical to the Type 2 basalt of Hole 504B; that is, a sparsely plagioclaseolivine-clinopyroxene phyric basalt.

Plagioclase forms 30 to $45 \%$ of the rock as phenocrysts, glomerocrysts, or microlites. The proportion of phenocrysts to glomerocrysts is variable. Generally phenocrysts (maximum length: $1.0 \mathrm{~mm}$; average: $0.4-0.6$ $\mathrm{mm}$ ) are more common, but glomerocrysts account for a large proportion of the macroscopic feldspar because of their large size (maximum diameter: 1.2-2.5 mm; average: $1.0-1.2 \mathrm{~mm}$ ), which is often twice that of single phenocrysts.

Glomerocrysts range from 0.6 to $2.5 \mathrm{~mm}$ in diameter, comprising many (15-20) small, randomly arranged euhedral and subhedral phenocrysts. No pronounced crystal zoning was observed. Some cores contain glass inclusions. Skeletal forms resulting from growth at marked undercoolings and the colander-like perforations induced by clay alteration occur but are rare.

Phenocrysts are euhedral or subhedral, with some degree of zoning toward more sodic rims. In a few cases, minor anorthite-rich layers are evident within more albitic rims, indicating oscillations in magma composition during crystallization. Many of the phenocrysts show mosaics of hairline fractures filled by clays. In the rare cases where the phenocrysts are situated in zones of intensive alteration, the phenocryst cores have been totally replaced, their rims remaining intact.

Microlites are common, forming 20 to $40 \%$ of the rock (maximum length: $0.6 \mathrm{~mm}$; average: less than 0.2 $\mathrm{mm}$ ). They can be euhedral or subhedral and are dendritic and skeletal. In many samples they show strong alteration. Optically measured, the plagioclase has a range in anorthite composition between $\mathrm{An}_{67}$ and $\mathrm{An}_{78}$ (average: $A n_{72}$ ), with rims from $\mathrm{An}_{60}$ to $\mathrm{An}_{67}$.

Olivine is found as euhedral and subhedral phenocrysts and as a minor component of the groundmass. The phenocrysts, which are pseudomorphed by clays and calcite, vary in size from 0.2 to $1.0 \mathrm{~mm}$ (average: $0.3-0.5 \mathrm{~mm}$ ). They form 2 to $3 \%$ of the rock. Groundmass olivine is present as anhedral or subhedral grains 0.05 to $0.15 \mathrm{~mm}$ in diameter; it can occasionally be skeletal. 
Clinopyroxene occurs as single grains, aggregates, and as a component of the groundmass. It constitutes $40 \%$ of the rock.

Ophitic and subophitic clinopyroxene is common in these rocks $(5 \%)$, consisting of single anhedral grains $(0.1-0.4 \mathrm{~mm})$ or aggregates that enclose plagioclase microlites. The clumps (maximum diameter: $1.2 \mathrm{~mm}$; average: $0.4-0.8 \mathrm{~mm}$ ) are rarely completely ophitic and exhibit radial extinction in polarized light; this is probably the result of crystal growth.

Clinopyroxene in the groundmass can occur in several different forms, including granules and spherulites. Most of the rocks except those chilled at pillow margins have a 3 to $5 \%$ proportion of anhedral augite in their groundmass $(0.05-0.1 \mathrm{~mm})$. These grains often have arborescent sprays of clinopyroxene linking them to the pyroxene component of the spherulites, although they can be distinct. Sprays are absent from the larger ophitic crystals and aggregates.

The remainder of the rock is groundmass $(\sim 40$ $50 \%$ ). The groundmass contains granular clinopyroxene, subhedral olivine, and acicular plagioclase in a spherulitic matrix composed of clinopyroxene, plagioclase, and opaques. In fine-grained rocks the mesostasis appears dark brown and is composed of fan spherulites. In coarser rocks the matrix becomes paler, and the fan spherulites develop into plumose fans and then into dendrites. Some samples have a more variolitic texture consisting of irregular patches of dark fan spherulites in a light dendritic matrix.

Opaques constitute up to $3 \%$ of the rocks. Primary opaques include titanomagnetite and Fe-rich sulfides (pyrrhotite). Titanomagnetites occur as skeletal to euhedral crystals. Primary sulfides occur as blobs disseminated in the glass and mesostasis.

Secondary opaques include pyrite and $\mathrm{Fe}$-oxides. Secondary pyrite occurs as euhedral and subhedral grains in and around vesicles, and as long, wide, veinlike aggregates of skeletal pyrite which permeate the rock. Pyrite close to vesicles may also form discontinuous rims around cavities and occasionally around olivine pseudomorphs. Except when veinlike aggregates are present, secondary pyrite is found only as a trace $(<0.5 \%)$.

Titanomagnetite (average: $2 \%$ ) is confined to the mesostasis and occurs as crystals, most of which are very tiny. The larger grains are generally skeletal, although euhedral and subhedral grains do occur. Grains are disseminated but can occasionally be concentrated as discontinuous strings between clinopyroxene crystals and spherulite sprays.

$\mathrm{Fe}$-oxide minerals, possibly hematite or goethite, are found in several samples as layered linings of vesicles and veins.

\section{Holes 501 and 504B}

The basement recovered from Holes 501 and 504B can be divided into five petrographic groups on the basis of the phenocrysts observed in thin sections. These may differ somewhat from those observed with a hand lens, which form the basis of the lithologic units (Fig. 4), but the numbers and intervals of the petrographic types correspond to those of the lithologic units. The five basalt types are as follows:

\begin{tabular}{cc}
\hline Type & Thin-Section Phenocryst Assemblage \\
\hline 1 & $\begin{array}{c}\text { Moderately plagioclase, olivine, and } \\
\text { chrome spinel phyric (no green } \\
\text { clinopyroxene) } \\
\text { Moderately plagioclase and augite } \\
\text { phyric (no spinel, no green clino- } \\
\text { pyroxene, and no olivine) } \\
\text { Moderately plagioclase, olivine, and } \\
\text { green clinopyroxene phyric (no } \\
\text { spinel) }\end{array}$ \\
4 & $\begin{array}{l}\text { Highly plagioclase, olivine, and green } \\
\text { clinopyroxene phyric (no augite) } \\
\text { Variably plagioclase, olivine, } \pm \text { augite } \\
\text { phyric (no spinel and no green } \\
\text { clinopyroxene) }\end{array}$ \\
\hline &
\end{tabular}

Type 1

Basalts of Type 1 are sparsely to moderately plagioclase-olivine phyric with accessory chrome spinel and no green clinopyroxene phenocrysts.

Megascopically, the plagioclase occurs as glomerocrysts and single phenocrysts, which together form 5 to $10 \%$ of the rock. Plagioclase microlites and a proportion of the groundmass account for a further 20 to $30 \%$ of average Type 1 basalt.

Glomerocrysts can form up to $7 \%$ of the rock, with average dimensions between 0.6 and $1.2 \mathrm{~mm}$ (maximum length: 2.0 to $2.5 \mathrm{~mm}$ ). Phenocrysts contributing to these chaotic clumps may be euhedral or subhedral and are often poikilitic, containing anhedral plagioclase crystals. Glass inclusions are sometimes present in crystal cores, but they are not common. Some degree of zoning can usually be seen, but it is never as pronounced as that visible in the larger phenocrysts. More albitic rims with oscillations for more anorthitic plagioclase, as present in Type 2 basalts, are virtually absent. Clay minerals are common along cracks in the smaller grains, forming glomerocrysts.

Phenocrysts are generally euhedral or subhedral, forming 3 to $8 \%$ of the rock. The largest are 2.0 to $3.0 \mathrm{~mm}$ long, and the average is 0.4 to $0.8 \mathrm{~mm}$. There appears to be no relationship between the size of individual phenocrysts and glomerocrysts in the same rock. Generally the sizes of the phenocrysts are distributed evenly between two extremes, although occasionally they fall into two distinct groups with no intermediate-sized grains. In such cases the largest phenocrysts are 2.5 to $2.8 \mathrm{~mm}$ long (average: $\sim 1.5-2.0 \mathrm{~mm}$ ), and the smaller are around $0.8 \mathrm{~mm}$ (average: $0.3-0.6 \mathrm{~mm}$ ). Many phenocrysts contain glass inclusions in their cores, and some contain anhedral plagioclase grains. Skeletal textures are common. There are rare examples of phenocrysts with margins made of tightly packed dendrites and parallel strings of clay (altered glass?). Zoning to more sodic rims is common, sometimes with calcic oscillations near their cores. 
Clay fills cracks in some phenocrysts. Plagioclase composition varies between $\mathrm{An}_{68}$ and $\mathrm{An}_{78}$ (average: $\mathrm{An}_{75}$ ); rims are approximately $\mathrm{An}_{65}$.

Plagioclase also forms dendritic groundmass and microlites, totaling 20 to $30 \%$ of the rock. The phenocrysts vary in size from 0.05 to $0.8 \mathrm{~mm}$, with morphologies varying from euhedral through skeletal to dendritic. Microlites often form radiating subophitic textures when granular pyroxene is present, but generally they have no orientation. Clay fillings are common in fractures.

Olivine phenocrysts $(2-3 \%)$ occur as euhedral and subhedral grains. There is usually a gradation in phenocryst size from larger $(1.2-1.5 \mathrm{~mm})$ to smaller (average: $0.1-1.4 \mathrm{~mm}$ ). These phenocrysts are distinct from intersertal groundmass olivine $(0.025-0.05 \mathrm{~mm})$. These proportions vary; groundmass olivine is anhedral and granular, but clumps of skeletal crystals $(0.2 \mathrm{~mm}$ long) occur occasionally. Both phenocryst and matrix olivine (total $\sim 10 \%$ ) are pseudomorphed by clays.

Clinopyroxene ( $\sim 35 \%$ of the rock) is an important component of the groundmass, where it forms spherulites. A small percentage forms subhedral grains or skeletal laths $(0.05-0.2 \mathrm{~mm}$ long) distinct from the mesostasis. These often have arborescent sprays connecting them with the spherulitic matrix. Rarely grains coalesce to form vague ophitic textures enclosing plagioclase microlites (maximum diameter: $0.8 \mathrm{~mm}$ ).

The proportions of groundmass and mesostosis are dependent on the degree of chilling the basalt has undergone. Near the margins the matrix may form $85 \%$ of the rock, but where there is a high proportion of acicular plagioclase (flow interiors), the matrix forms only $40 \%$. Small spherulites at margins $(0.1-0.15 \mathrm{~mm}$ in diameter) become progressively larger toward interiors. Fan spherulites develop into plumes and then into dendrites of plagioclase and clinopyroxene dusted with opaques. In the coarser basalts, the pyroxene dendrites may become skeletal.

Euhedral chrome-spinel phenocrysts $(<3 \mathrm{~mm})$ generally form less than $0.5 \%$ of the rock. They can be vermicular and sometimes skeletal. Most chrome spinel is disseminated in the mesostasis, but it can be poikilitically enclosed in olivine or plagioclase phenocrysts.

\section{Type 2}

Basalts of Type 2 are moderately plagioclase and augite phyric. Ophitic, subophitic, and intersertal textures are dominant, with finer-grained equivalents resulting in glassy to variolitic basalts.

The plagioclase crystals are sometimes zoned, often twinned according to albite, pericline, and Carlsbad laws, and exhibit blocky to equant, lathy morphologies. Anorthite content was determined optically for the phenocryst phases as $\mathrm{An}_{80}$ to $\mathrm{An}_{90}$. No major change in $\mathrm{An}$ content occurs within stratigraphic succession in either the matrix or phenocrystic plagioclase. In all cores the median of the matrix crystals is less anorthite rich than that of the phenocrysts. This relationship is to be expected if the phenocrysts crystallized in a basaltic parent that was slightly less differentiated or hotter than the erupted lava.
Clinopyroxene phenocrysts are subhedral to anhedral, rarely twinned, occur usually in agglomerates of two or more, and may (rarely) appear resorbed. These crystals are biaxial positive with a large $2 \mathrm{~V}$ and have maximum extinction angles that never exceed $45^{\circ}$. The maximum extinction angles generally range from $35^{\circ}$ to $45^{\circ}$. In plane-polarized light the relief is high against plagioclase laths and somewhat lower than olivine; these crystals also exhibit a light green hue in plane-polarized light but are not pleochroic. Although $2 \mathrm{~V}$ angles could not be measured accurately, the previous description is appropriate for augite.

Groundmass textures range from glassy to completely crystallized and intergranular. Several different textures are often present in one sample, progressing from a glassy rind to an intermediate zone of variolites toward a core of hyalopilitic texture. Generally, such samples represent a flow or pillow margin. Microlites in these samples are generally of two morphological and mineralogical types: (1) acicular plagioclase (approximately $\mathrm{An}_{58-60}$ ), and (2) anhedral granular, clinopyroxene (maximum extinction angle between $30^{\circ}$ and $45^{\circ}$ ).

\section{Type 3}

Basalts of Type 3 are moderately plagioclase-olivineclinopyroxene phyric. They are petrographically distinguished from the other groups by their high phenocryst content $(15-20 \%)$ and by the presence of large single augite crystals.

Megascopic plagioclase is in the form of phenocrysts and glomerocrysts, which together form 20 to $25 \%$ of the rock.

Phenocrysts range in size from 0.2 to $3.5 \mathrm{~mm}$. The number of phenocrysts of each size is about the same. There is, however, a tendency for some basalts to have a higher proportion of phenocrysts in the ranges from 0.4 to $0.6 \mathrm{~mm}$ and 0.8 to $1.5 \mathrm{~mm}$. In cases where the phenocrysts are predominantly of one of these sizes, large grains $(3.0-4.0 \mathrm{~mm})$ are rare. Irrespective of size, most of the phenocrysts are euhedral, with a few subhedral and dendritic forms. Twinning can be complex or simple; generally one or the other will be dominant in any single thin section. Zoning varies between rocks from being vague on extinction to distinct in albite-rich rims. Phenocrysts with vague oscillatory zoned cores and sharp thin sodic rims are most common. Phenocryst cores with glass inclusions are rare, as are phenocrysts with skeletal textures. Occasionally the larger phenocrysts are poikilitic, containing small euhedral feldspar grains. A parallel alignment of megacrystic plagioclase and small phenocrysts occurs in some localized areas. Generally the plagioclase is fresh, but near areas of intense alteration crystal cores may be partially or completely pseudomorphed by clays, leaving only the sodic rim intact.

Plagioclase glomerocrysts tend to be more common than individual phenocrysts in these basalts, but they are comparable in size, ranging between 0.8 and $4.0 \mathrm{~mm}$ at their widest point. The glomerocrysts are composed of 5 to 30 phenocrysts of varying size, but in general the small glomerocrysts are made of correspondingly small phenocrysts. Individual grains are euhedral or subhe- 
dral but never dendritic. In general, clumps are loosely and chaotically arranged. They are formed of phenocrysts which are often poikilitic, completely or partially containing anhedral or subhedral plagioclase grains. Phenocrysts show complex twinning and invariably have some degree of oscillatory zoning in their cores, with a sharp outer rim. There are no glass inclusions. Alteration, if sufficiently intense, can replace cores, but it leaves rims intact. The composition of the plagioclase in these rocks varies between $\mathrm{An}_{68}$ and $\mathrm{An}_{82}$ (average: $\sim A n_{75}$ ), with rims of about $\mathrm{An}_{63}$.

Plagioclase also occurs as microlites, forming 5 to $15 \%$ of the rock, the proportion appearing to be dependent on the crystallinity of the groundmass. The microlites vary in size from 0.05 to $0.8 \mathrm{~mm}$, the largest often grading into the size of microphenocrysts and being distinguished only by their narrow form. They show no consistent orientation, but they are occasionally included in radiating ophitic clinopyroxene clumps. The smaller microlites are skeletal and dendritic; the larger microlites are only euhedral. They are strongly corroded by clays in localized areas of intense alteration.

Olivine forms 3 to $8 \%$ of the basalts from this group, as euhedral or subhedral grains. The grains range in size from 0.1 to $1.6 \mathrm{~mm}$, but most are between 0.3 and 0.5 $\mathrm{mm}$. Olivine is generally found as single grains, but occasionally aggregates of several (three or four) phenocrysts may occur, with rare ophitic textures. In basalts where the phenocrysts are generally larger than normal, olivine can be divided into two size ranges: phenocrysts and groundmass-sized grains (0.1-0.2 mm). Alteration is intense in most of these rocks, with colored clays replacing both the phenocryst and the groundmass olivine.

Clinopyroxene is present in the form of large phenocrysts and aggregates (2-15\%) and as spherulites in the groundmass. The phenocrysts are euhedral or anhedral, and they generally occur in two size ranges. The larger grains are around 0.2 to $4.2 \mathrm{~mm}$ in length, the smaller about 0.05 to $0.2 \mathrm{~mm}$. Usually there are only three or four large phenocrysts, and they generally show some degree of simple twinning (sector or straight). There is a tendency for the smaller grains $(0.05-0.1 \mathrm{~mm})$ to be more ophitic than those in the size range from 0.2 to 4.2 $\mathrm{mm}$. Grains commonly coalesce to form radiating ophitic clumps with diameters up to $2.0 \mathrm{~mm}$; alternatively, they are single and intersertal to the groundmass, acting as nuclei for fan spherulites. Smaller phenocrysts and aggregates are often dendritic and connected with the clinopyroxene of the groundmass by arborescent sprays. This is particularly pronounced in the less dense aggregates. Rarely, the larger single phenocrysts are poikilitic, containing small euhedral plagioclase grains.

The groundmass of these basalts is predominantly of fine-grained spherulitic form. Depending on the degree of crystallinity, it can form 60 to $80 \%$ of the rock. In general, the more spherulitic the groundmass, the lower the percentage of the plagioclase microlites and augite aggregates present. Away from pillow margins, where rounded spherulites nucleating around laths and grains are most common, the matrix becomes progressively more fanlike, then plumose, and finally dendritic. The ground- mass of many basalts has a vaguely variolitic texture. A matrix of granular augite and acicular plagioclase may be randomly spotted with areas comprising dense spherulitic textures. The matrix in all these basalts is heavily dusted with opaques.

A few of the basalts in the upper half of the core show the effects of autointrusion; others show intensive fault brecciation.

Autointrusion can be found in Lithologic Unit 3 of Hole 504B from $85 \mathrm{~cm}$ down Core $15-5$ to the top of Core 16-2. It appears as fingers and spots of fine-grained basalt ramifying a coarser host. The basalts involved are not as strongly phyric as many of the others included in Type 3 , but they nevertheless contain the required phenocrysts of clinopyroxene. In thin section both the coarse- and the fine-grained basalts contain phenocrysts of plagioclase and clinopyroxene that are comparable in size and percentage $(5-10 \%)$. Near contacts the finer basalt has a dark, dense matrix composed of fan spherulites and rare microlites. In plane polarized light, dark and light flow laminations can be seen running parallel to the contact; the laminations contain similarly oriented acicular plagioclase. Farther from the contact the matrix becomes less compact and lighter in color. As the microlite content increases, flow laminations lose all orientation, fans become plumose, and granular augite begins to appear. Such relationships suggest injection and chilling. Contacts are lobate and rounded, the result of intrusion while the host was still plastic and deformable. The host has a coarser groundmass of acicular plagioclase with dendritic and granular augite. Phenocrysts close to the contact can be partially enveloped by intruding material.

From the evidence it would appear that a source of hot new magma of composition similar to that already present (possibly in a magma chamber) became available for injection into a host that was cooler but still partially molten.

Breccias appear at several horizons in the core. In thin section the breccias comprise subrounded fragments up to $4 \mathrm{~mm}$ across. The fragments can be shattered parts of mineral grains or pieces of rock broken from the adjacent fracture wall or elsewhere. The polymict form of this breccia is clearly seen from the presence of pillow margins, aphyric, and Type 3 basalts in the same thin section. The breccia acted as a channel for intense alteration, replacing partially or completely all but the largest or most resistant rock fragments. These are now held in a matrix of clay.

\section{Type 4}

Type 4 basalts occur in Holes 504B and 505 and are moderately plagioclase-olivine-clinopyroxene phyric. They are differentiated from Type 1 basalts by the presence of clinopyroxene phenocrysts and by the size of the phenocryst component of the rock. About $30 \%$ of the basalt is made up of phenocrysts, of which $20 \%$ are plagioclase and $10 \%$ are olivine, with traces of clinopyroxene.

Plagioclase occurs as phenocrysts and glomerocrysts of variable size (maximum length and diameter: 2.5 $\mathrm{mm}$; average: $1.5-2.0 \mathrm{~mm}$ ). Composition is constant 
for all the plagioclase morphologies $\left(\mathrm{An}_{78}-\mathrm{An}_{85}\right)$; pronounced zoning toward a more sodic rim is common. Anhedral glass inclusions occur in the cores of several crystals; less common are ophitic plagioclase megacrysts containing inclusions of anhedral olivines and chrome spinel. There are some partially resorbed feldspar phenocrysts.

Olivine $(2.5-1.0 \mathrm{~mm})$ is present as euhedral or subhedral phenocrysts, some of which are skeletal, and as glomerocrysts. The glomerocrysts are often ophitic or subophitic, the grains having inclusions of euhedral plagioclase. Blue and green smectites partially replace the larger olivine phenocrysts and all of the groundmass olivine.

There are a few clinopyroxene phenocrysts. In gener$\mathrm{al}$, they are anhedral and twinned (4.0-1.0 mm long). Their rounded and corroded appearance suggests a degree of resorption. In hand specimen they appear as bright emerald green crystals.

The groundmass is identical to that of type, containing plagioclase microlites $(10-20 \%)$ in a spherulitic mesostasis $(50-55 \%)$.

Pyrite and titanomagnetite form $\sim 2 \%$ of the basalt. Pyrite is limited to veining and is consequently secondary. Submicroscopic titanomagnetite is disseminated in the mesostasis as euhedral grains.

\section{Type 5}

Type 5 basalts are plagioclase-olivine-augite phyric, with augite occurring only as glomerocrystic clumps with plagioclase. Phenocryst contents are variable, so for the purpose of discussion only their extremes are considered. These are microphyric and sparsely to moderately phyric basalts. All gradations between are found.

The petrographic characteristics of the sparsely to moderately phyric Type 2 basalts have been described in detail in the discussion of Hole 504A, where the only basalt recovered was of this type.

The microphyric (subaphyric) basalts of Type 2 differ from more phyric basalts in having only $6 \%$ or less of phenocrysts ( $<1.0-1.5 \mathrm{~mm}$ in length). The phenocrysts are composed of plagioclase and olivine.

Plagioclase forms 10 to $15 \%$ of the rock as phenocrysts, glomerocrysts, and microlites. Most of the phenocrysts found in these basalts fall into one of two ranges: 0.2 to $0.7 \mathrm{~mm}$ (average: $0.4-0.6 \mathrm{~mm}$ ) and 0.8 to $1.0 \mathrm{~mm}$ long. Rocks containing only the larger phenocrysts are relatively rare; they generally occur in combination with smaller phenocrysts or are (more commonly) absent. Irrespective of size, phenocrysts are generally euhedral and normally zoned; one case of sector zoning was observed. There is a very gradual increase in soda content from the cores towards rims, lacking sharp or oscillatory changes during growth. A few of the smaller phenocrysts appear corroded and almost anhedral in form, indicative of partial resorption or magmatic abrasion. Twinning is simple in the majority of grains, consisting of one or two broad twins. The smaller phenocrysts tend to be more dendritic than the larger grains. Inclusions are rare or absent. Alteration appears as clayfilled cracks and is most pronounced in the smallest phenocrysts.
Glomerocrysts of plagioclase are rare (one or two per thin section) or absent. They are formed of chaotic clumps of 5 to 10 euhedral or subhedral phenocrysts $(0.2-0.4 \mathrm{~mm})$, some of which are partially or completely enclosed by others. Generally they are 0.8 to $1.2 \mathrm{~mm}$ across. Glomerocrystic grains are identical to single phenocrysts in zoning, simple twinning, and occasional dendritic morphology. Plagioclase composition varies between $\mathrm{An}_{74}$ to $\mathrm{An}_{82}$ (average: $\mathrm{An}_{76}$ ), with rims of approximately $\mathrm{An}_{68}$.

Most plagioclase is in the form of microlites (10$20 \%$ ). The microlites range in size from 0.05 to $1.6 \mathrm{~mm}$, but average 0.1 to $0.4 \mathrm{~mm}$, depending on the crystallinity of the rock. Generally they have a random orientation, but they may form radiating ophitic textures when granular augite is present in the groundmass. Most microlites are subhedral or euhedral. Skeletal forms are not common. They can be dendritic, and in pillow margins they act as nuclei for fan spherulites.

Olivine phenocrysts form 3 to $4 \%$ of the basalts. They range in size from 0.05 to $0.4 \mathrm{~mm}$, with an average between 0.2 and $0.3 \mathrm{~mm}$. Grains are commonly euhedral or (rarely) subhedral. In most sections olivine is completely replaced by clays or $\mathrm{Fe}$-oxide minerals.

Clinopyroxene occurs as single grains and as amorphous aggregates, forming in total 10 to $25 \%$ of the rock. Single grains are at maximum $0.3 \mathrm{~mm}$ long (average: $0.05-0.2 \mathrm{~mm}$ ) and are therefore large components of the groundmass rather than microphenocrysts. They range from euhedral to subhedral. Single grains, which are occasionally skeletal in form, are randomly scattered in the rock, but the grains sometimes coalesce to form clumps. Rarely, individual grains are subophitic with plagioclase and exhibit undulose extinction (average diameter: $0.1-0.2 \mathrm{~mm}$ ). The grains sometimes act as nuclei for poorly developed bow-tie structures, but generally they are texturally independent of the groundmass. Clumps are distinct from other aggregates of smaller diffuse granules $(0.05 \mathrm{~mm})$ in that they are made of clear subhedral grains and are nonophitic.

Aggregates of augite, on the other hand, are composed of a mass of anhedral granules and are always ophitic. Each aggregate can be 0.2 to $0.4 \mathrm{~mm}$ across, but most are about $0.2 \mathrm{~mm}$. Occasionally several loose aggregates coalesce to form continuous areas of ophitic texture in a dense spherulitic groundmass. In coarser basalt, ophitic areas increase in proportion to the amount of granular augite. The grains that form these aggregates have arborescent sprays joining them to the matrix, but they are absent from most of the clumped and phenocrystic augite.

Dense fanlike spherulites are characteristic of finegrained rocks; they contain only a small number of microlites and granular augite. Acicular plagioclase crystals may occasionally act as nuclei for spherulite growth. Fan spherulites vary from fanlike to plumose and finally to dendritic as the basalt coarsens. Also associated with the coarsening basalt is an increase in augite content in the form of aggregates, clumps, and grains. Coarse rocks usually have a variolitic matrix, whereas areas of dense spherulites heavily dusted with opaques are scattered in 
a more plumose and granular-ophitic groundmass rich in microlites.

\section{Opaque Mineralogy}

Titanomagnetite and primary sulfide spherules are ubiquitously found in the interstices of silicate phases (regardless of the basic texture), and they never occur in an equigranular-intergranular relationship with the silicates. Crystal textural and morphological relationships indicate that the silicates crystallized before the interstitial phases. This relationship implies that the final crystallization of these opaques occurred well after the main silicate-crystal framework of the solidifying melt had been established. In addition, the sulfide spherules are flattened against both the silicate crystals and the titanomagnetites, indicating that these spherules represent droplets of an immiscible sulfide melt, liquidated from the silicate magma, that solidified after the main stage of silicate and oxide crystallization.

Titanomagnetites dominate the opaque mineral phases in grain size and abundance, ranging from 5 to $10 \mu \mathrm{m}$ in average diameter in different samples and constituting from 4 to $10 \%$ of rock volume in different samples. These oxides often occur in areas where the primary interstitial silicate matrix has been replaced by smectite. In such areas two types of alteration of the primary oxides were recognized: (1) direct oxidation to red, $\mathrm{Fe}$-oxyhydroxide and (2) development of "oxidative shrinkage" cracks. These alteration products are rare in the polished thin sections available, occurring only in thin sections from Hole 504B, Core 39, Section 1, 43-50 cm and Hole 504B, Core 52 , Section 3, 97-99 cm, respectively.

Primary sulfide spherules are less common than in the Galapagos Rift samples drilled on Legs 54 and 70, but they occur in all samples where the titanomagnetites are large enough to discern morphology (>5 $\mu \mathrm{m})$.

\section{Conclusions}

All basalt types carry mineralogical evidence for complex crystallization histories. This evidence includes partially resorbed plagioclase and clinopyroxene phenocrysts, plagioclase phenocryst interiors rich in inclusions, pronounced oscillatory zoning, and diverse phenocryst and microphenocryst morphologies that indicate formation at a range of undercoolings. The fact that the petrographic types display different combinations of these characteristics suggests that they were subjected to different influences during their formation. The groundmass is very similar for all basalt types and would appear to indicate that a similar magma type was involved in all cases, but that the magmas were subjected to different conditions of crystal fractionation and phenocryst addition to form each petrographic group.

\section{BASEMENT ALTERATION PETROGRAPHY, SITES 501 AND 504}

\section{Mineralogy}

Alteration of the basalts in Sites 501 and 504 appears in glassy margins, olivine and plagioclase crystals, veins, and miarolitic voids. The alteration minerals determined on board the Glomar Challenger are clay minerals, talc(?), carbonates, phillipsite, natrolite, analcime, iron hydroxides and/or iddingsite, and pyrite. The minerals occur as fillings of vesicles and veins and as replacements of olivine and sometimes plagioclase crystals. Other secondary minerals, such as quartz, K-feldspar, apophyllite, anhydrite, gyrolite, melanite, and aegirine augite, were found during shore-based studies.

\section{Clay Minerals}

Clay minerals are present in all three holes. The five types listed in Table 7 were distinguished.

The clay mineral typed as GY was analyzed on the ship by XRF during Leg 69; it seems to be saponite.

The mineral typed as EY, which was identified as talc in Hole 504B on board the ship using X-ray diffraction, was revealed on shore to be a Mg-rich clay mineral which is particularly colorless and highly birefringent (Honnorez et al., this volume). Possible interlayered talcsaponite minerals were identified by XRD in Cores 34 , $37,48,56$, and 57.

\section{Carbonates}

Carbonates occur in Hole 501 (Cores 12-17 and 20), in Hole 504A (Core 6), and in Hole 504B (Cores 3-9, 14, $16,17,20-24,27,28,33$ to 35,37 to 41 , and 48 ). The presence of calcite in Hole 504B (Core 44) was confirmed by XRD during Leg 70. In Hole 504B carbonates are particularly abundant in veins, where they are associated with clay minerals, analcime, and other zeolites. Carbonates occur associated with clay minerals as a product of olivine alteration in Hole 504B, Cores 5 to 9, $16,17,21$ to $24,27,38,41$, and 45 .

\section{Phillipsite}

Phillipsite is present in altered glassy margins, where it is associated with clays. It shows fan-shaped aggregates of elongated or square crystals with very low birefringence. A large radiating clump of crystals $(1 \mathrm{~cm}$

Table 7. Clay minerals in basalts of Sites 501 and 504 .

\begin{tabular}{cllll}
\hline Type & Color in Normal Light & Color in Crossed Polars & Habit & Mode of Oecurrence \\
\hline $\begin{array}{l}\text { GY } \\
\text { EY }\end{array}$ & $\begin{array}{l}\text { Greenish yellow } \\
\text { Pale yellow green to colorless }\end{array}$ & $\begin{array}{l}\text { Gray to yellow (first order) } \\
\text { Gray (first order) to yellow } \\
\text { (second order) }\end{array}$ & $\begin{array}{l}\text { Fibers } \\
\text { Fibers }\end{array}$ & $\begin{array}{l}\text { Breccia cement, glassy margins } \\
\text { Olivine replacement, vesicle and } \\
\text { vein fillings (plagioclase re- } \\
\text { placement) }\end{array}$ \\
G & Green & Anomalous dark green & Granules & $\begin{array}{l}\text { Olivine replacement, vesicle and } \\
\text { vein fillings } \\
\text { Olivine replacement } \\
\text { Olivine replacement, vein fill- } \\
\text { ings }\end{array}$ \\
BG & Blue green & $\begin{array}{l}\text { Anomalous bluish gray } \\
\text { Gray to red (first order); } \\
\text { sometimes superimposed } \\
\text { on anomalous green }\end{array}$ & $\begin{array}{l}\text { Fibers } \\
\text { Fibers }\end{array}$ & \\
\hline
\end{tabular}


across) was found in Hole 504B on the surface of Core 11, Section 3, Piece 1079.

\section{Zeolites}

Various unidentified zeolites occur in Cores 35 to 41 of Hole 504B. Megascopically, a white zeolite occurs in veins as fibroradiate aggregates up to $10 \mathrm{~mm}$ in width; the aggregates are associated with dark green smectite and sometimes analcite. Natrolite was identified by XRD in veins of Cores 35 to 37 . White material that occurs in veins below Core 49 is quartz (Honnorez et al., this volume).

\section{Analcime}

Analcime occurs in Hole 504B (Cores 35, 37, and 38) as colorless transparent crystals (to $1.0 \mathrm{~mm}$ in size) in open cracks and veins, where it is in association with clay minerals, probably natrolite, calcite, and sometimes a light bluish transparent mineral. The presence of analcime in Core 35 was confirmed by XRD.

\section{Iddingsite}

Different kinds of iddingsite (i.e.; various mixtures of clay minerals and iron hydroxides) occur in Holes 501 and 504B. It occurs as red, orange, or brownish material that has abnormal dark red, orange, and brown colors in crossed polars. It was found in and around the cracks of olivine phenocrysts, which are completely replaced by clay minerals. An iddingsitelike material, compositionally identical to that replacing olivines (Honnorez et al., this volume), also occurs in the matrix, cracks, vesicles, and miarolitic voids, generally in association with clay minerals.

Iddingsite and iddingsitelike material may be responsible for the red color of "alteration halos" around cracks.

\section{Pyrite}

Pyrite appears in variable amounts in veins, where it is associated with dark green smectite. It is rare in Holes $501,504 \mathrm{~A}$, and the upper part of the Hole 504B but more common in the lower part of Hole 504B (e.g., Cores 36, $38,40,41,45,47-50,52$, and 54-70). The frequency, abundance, and size of the grains of pyrite increase with depth (maximum length: $2 \mathrm{~mm}$; maximum length of agglomerates of crystals: $6 \mathrm{~mm}$ ).

\section{Alteration Zoning around Cracks}

Oxidative alteration is often marked by zoning along cracks. The materials that appear as one moves from the fresh rock to a crack or exposed surface are as follows: (1) Type EY clay mineral; (2) Type EY clay mineral plus iddingsite; and (3) Type G clay mineral (not always present). This disposition is general in Hole 501 and in the upper part of the Hole 504B. Below Core 39 in Hole 504B it disappears.

\section{Replacement of Igneous Minerals}

Pyroxene crystals are almost always fresh (see Laverne, this volume).
Plagioclase crystals are sometimes partly altered to clay minerals (Type EY), and more rarely are replaced by analcite and other zeolites (Cores 35, 37, and 38). Titanomagnetite crystals are often rather strongly altered; they are frequently almost completely replaced by nonopaque minerals or mineral assemblages. In such cases, fresh titanomagnetite occurs as tiny $(<0.001 \mathrm{~mm})$ relics scattered in the alteration products, and the original titanomagnetite crystal outlines are visible only in transmitted light. The nature of the alteration products could not be identified on the ship because of the rather poor polish of the sections. Titanomaghemite and other $\mathrm{Fe}-\mathrm{Ti}$ oxides/hydroxides are probably present, as well as sphene.

Olivine is always at least partly altered, and most of the time it is completely altered. The following associations occur as a replacement for olivine: (1) pale green smectite (Type EY); (2) colorless to pale green smectite (Type EY) plus iddingsite; (3) blue green smectite (Type BG); (4) green smectite (Type G); and (5) pale green smectite (Type EY) plus dark olive green smectite (Type DG) plus opaque needles.

The Type (2) association occurs in red halos around cracks, whereas Type (1) occurs outside the halos, in the nonoxidized zones. The Type (1), (2), and (4) associations are common in the upper part of the hole (above Core 39). The Type (3) association occurs above Core 39 , but it is rare. The Type (5) association occurs below Core 39. The Type (1) and (2) associations were observed in the same thin section (Sample 504B-33-2 [Piece 207]). One part of the thin section shows Type (1) alteration, whereas the other part shows Type (2) alteration. The contact between these two zones is very sharp, with the same olivine phenocryst exhibiting both types of alteration. The zonation is controlled by the presence of a crack (see preceding material).

\section{Variation of Alteration with Lithologic Type}

Alteration varies with the two main lithologic types of lava. The first type comprises the pillow basalts and breccias, which are characterized by the presence of glass, fine-grained basalts, and numerous cracks. The alteration minerals are varied and abundant (analcime, pyrite, calcite, smectites, zeolites). They fill thick (8-mm) cracks and replace glass and olivine. The second type comprises the massive basalts, which are medium grained and probably represent flows most of the time. Cracks are much rarer and thinner $(<0.5 \mathrm{~mm}$ in width). In these, alteration is typically less advanced; however, the alteration minerals are similar to those in the pillows and breccias.

\section{Variation of Alteration with Depth}

Some variation in the alteration of the basalts with depth can be observed. The amount of pyrite increases with depth, whereas the abundance of carbonate decreases. In Hole 504B iddingsite is rare below Core 39; zeolites and analcime do not occur below Core 39; and phillipsite does not occur below Core 23. In addition, the Type (1), (2), (3), and (4) associations of olivine re- 
placement do not occur below Core 39 , whereas the Type (5) association seems to be present only below Core 39.

It was obvious on board that Core 39 of Hole 504B corresponded roughly to a boundary between two kinds of alteration, and this was confirmed on shore (Honnorez et al., this volume). The Core 39 boundary was not sharp, however, but extended for several cores.

The amount of altered material (although not necessarily the intensity of the alteration) depends also on lithologic type, including the density of the fractures, the grain size, the pore space volume and so forth-in other words, effective permeability. The tendency of a rock to alter depends on the latter parameter.

In summary, the basalts of Sites 501 and 504 show two types of alteration: oxidative alteration, which occurs in Holes 501 and 504A and in the upper part of the Hole 504B (to about Core 39), and a nonoxidative, possibly reducing type of alteration, which occurs in the lower part of Hole 504B (below about Core 39).

\section{BASEMENT CHEMISTRY, SITES 501 AND 504}

This discussion of the chemistry of the basalts in Holes 501, 504A, and 504B is based on (1) shipboard XRF measurements, (2) shore-based trace element data (Etoubleau et al., this volume), and (3) the composition of the natural basaltic glasses as determined by electron microprobe (Natland et al., this volume).

The XRF data show that the basalts are relatively basic, with values of $\mathrm{Mg} /(\mathrm{Mg}+\mathrm{Fe})$ from 0.56 to 0.66 (mean: 0.61 ); $\mathrm{Ni}$ from 70 to $170 \mathrm{ppm} ; \mathrm{Zr}$ from 30 to 100 ppm (with a concentration near $55 \mathrm{ppm}$ ); and $\mathrm{TiO}_{2}$ from 0.7 to $1.4 \%$ (with a concentration near $1.0 \%$ ). No ferrobasalts were encountered.

Except for two small intervals, all the basalts are depleted (N-type) mid-ocean ridge basalts. In fact, they have such low abundances of mobile-incompatible (hygromagmatophile) elements that they can be considered particularly depleted variants of $\mathrm{N}$-type mid-ocean ridge basalts. The two exceptional intervals occur from Cores 16 to 18 and 54 to 56 (Lithologic Units 4, 5, and 36). They contain basalts with elevated abundances of $\mathrm{K}_{2} \mathrm{O}$, $\mathrm{Na}_{2} \mathrm{O}$, and certain trace elements, and they have different ratios of $\mathrm{Nb} / \mathrm{Zr}$ and $\mathrm{La} / \mathrm{Ta}$ (Etoubleau et al., this volume). These lavas appear to have had a less depleted mantle source than the others.

The other basalts show a rather remarkable degree of uniformity, so much so that discrete chemical types in many cases could not be distinguished using XRF major oxide data because of the effects of phenocrysts and alteration. Better results were obtained using natural glass composition. Natland et al. (this volume) define 16 compositional groups that occupy different stratigraphic levels in the holes. Thirteen of these occur in Hole 504B, with an additional one in both Holes 501 and 504A. The least evolved glass compositions occur in Core 35. They have 9.2 to $9.5 \% \mathrm{MgO}$ and are only 0.81 to $0.83 \% \mathrm{TiO}_{2}$. They are among the most magnesian glasses analyzed from the eastern Pacific. The generally depleted character of the basalts is verified by the low percentage of
$\mathrm{K}_{2} \mathrm{O}(0.02-0.05 \%)$ and $\mathrm{P}_{2} \mathrm{O}_{5}(0.07-0.11 \%)$ in the composition of the glass. The largest coherent group of glass spans Cores 37 to 50 in Hole 504B. A smaller coherent group spans Cores 4 to 14 of Hole 504B; it occurs as well in Holes 501 and 504A. These and all other groups evidently represent individual eruptive units, and they appear in the pillows, flows, and breccias of most of the principal petrographic types. The abundance and occurrence of phenocrysts thus have little relationship to rock chemistry. The phenocrysts must therefore either be mechanical concentrates due to gravity sorting or flowage differentiation or have been introduced during magma mixing. As regards mixing, the extreme uniformity of the composition of both the whole rock and the glass implies uniformity in the magmatic processes at the Costa Rica Rift. In all likelihood, the uniformity reflects the effectiveness of a steady-state magma chamber in buffering magma compositions, primarily by mixing, prior to eruption.

\section{Sr AND Pb ISOTOPIC COMPOSITION OF HOLE 504B BASALTS}

Fourteen whole rock samples taken from Hole 504B at 40 - to 60 -meter intervals were analyzed for ${ }^{87} \mathrm{Sr} /{ }^{86} \mathrm{Sr}$ ratios and $\mathrm{Sr}$ and $\mathrm{Rb}$ concentrations. With one exception, samples were taken from holocrystalline pillows or massive basalts. Basalts containing major smectite or zeolite veins were not sampled because the intention of the study was to determine the degree of isotopic exchange between the crystalline bulk rock and seawater.

Seven samples from the upper 260 meters of the hole, down to Core 34 , have $\mathrm{Sr}$ isotope ratios of 0.70287 to 0.70377 , with an average of 0.70324 , and $R b$ values of 1.3 to $9.5 \mathrm{ppm}$. Six samples from the lower 300 meters of the hole have a very restricted $\mathrm{Sr}$ isotope ratio range (0.70255-0.70279) and an average value of 0.70265 , the value for fresh oceanic basalts. The $\mathrm{Rb}$ values are less than $0.5 \mathrm{ppm}$.

The elevated $\mathrm{Sr}$ isotopic values in the upper part of the hole can be interpreted in terms of limited isotopic exchange with seawater, which has a value of ${ }^{87} \mathrm{Sr} /{ }^{86} \mathrm{Sr}$ of 0.7091. Assuming an initial basaltic value of 0.70265 , the present range of values in the upper basalts implies a 3 to $17 \%$ (mean 9\%) contribution of seawater Sr. This $\mathrm{Sr}$ must be located mainly in the secondary smectites, which, together with minor iddingsite, replaces olivine in the upper basalts. In the lower half of the hole the basalts contain at least as much secondary smectite, but seawater $\mathrm{Sr}$ is negligible. This indicates that relative to the higher basalts, the lower basalts had notably less access to unmodified seawater. This could be the result of earlier filling of fractures, the lower flux of seawater in the lower basalts, or the reaction of the lower basalts primarily with isotopically modified seawater.

$\mathrm{Pb}$ isotopic ratios measured in 10 of the samples fall within the less radiogenic portion of the field of midocean ridge basalts. The ratios define a linear trend in a plot of ${ }^{208} \mathrm{~Pb} /{ }^{204} \mathrm{~Pb}$ versus ${ }^{206} \mathrm{~Pb} / 204 \mathrm{~Pb}$ and a roughly linear trend in a plot of ${ }^{207} \mathrm{~Pb} /{ }^{204} \mathrm{~Pb}$ versus ${ }^{206} \mathrm{~Pb} /{ }^{204} \mathrm{~Pb}$. There is no particular downhole trend in values. The ob- 
served variation is rather surprising, in view of the very limited variation in the composition of the fresh basalts and glasses in Hole 504B.

\section{BASEMENT STRUCTURE IN HOLES 501 AND 504B}

The orientation of glassy rinds and the inclination of fractures in oriented samples was determined for both Holes 501 and 504B. In all, 6302 fractures were counted. The rocks consist of alternating pillows and massive flows. The same general patterns of fracture inclination persist throughout both holes: namely, inclined fractures are proportionally more abundant in massive flows than in pillow units, but massive flows have fewer fractures overall. The total length of oriented recovered rock on which fracture inclinations could be counted was measured, and the average number of fractures per lithologic unit was determined. There are, overall, 1.82 fractures per centimeter of length of recovered oriented rock in Hole 504B. Pillow units in general average one fracture every $2 \mathrm{~cm}$ or less, whereas flows have fractures about every $2 \mathrm{~cm}$ or greater. The thickest massive flows have fractures every 3.5 to $4.5 \mathrm{~cm}$. There is no tendency for the frequency of fractures in the pillow units to increase with depth, but there is some tendency for the fracture density in flows to increase with depth. However, this may merely reflect the occurrence of relatively thin flows deeper in the hole.

The orientation of glass rinds indicates that pillows predominate in the hole, with few, if any, sheet flows. Autoclastic breccia zones cemented by clays were recovered more frequently toward the bottom of the hole, as were hyaloclastites. It was not possible to count fractures in such material. In all likelihood, however, this type of material is more abundant throughout the hole than is indicated by the recovery, and it is this material that is primarily responsible for the porosity of the crust.

\section{BASEMENT PHYSICAL PROPERTIES, SITE 504}

Basement physical properties measured at Site 504 include sonic velocity, wet bulk density, porosity, and thermal conductivity. Seismic velocity was determined with the Hamilton frame velocimeter from minicore samples cut for paleomagnetic study; wet bulk densityporosity samples were taken from the same piece of basalt and analyzed using gravimetric techniques. Thermal conductivity was, in almost all cases, determined for the same basalt piece that supplied the minicore and porosity sample.

Complete data and their interpretations are presented in Karato et al. (this volume).

Wet bulk density ranges from 2.73 to $3.02 \mathrm{~g} / \mathrm{cc}$, with an average of $2.9 \pm 0.06 \mathrm{~g} / \mathrm{cc}$. There is a general trend for wet bulk density to increase with depth; values are less than $2.90 \mathrm{~g} / \mathrm{cc}$ in the upper part of Hole 504B and greater than $2.90 \mathrm{~g} / \mathrm{cc}$ in the lower part. Grain density, which has a mean value of $3.00 \pm 0.03 \mathrm{~g} / \mathrm{cc}$ and a range from 2.92 to $3.07 \mathrm{~g} / \mathrm{cc}$, also increases with depth; values are generally below $3.00 \mathrm{~g} / \mathrm{cc}$ in the upper levels and greater than this value in lowermost cores. Porosity ranges from 1.3 to $13.3 \%$, with a mean of $5.0 \pm 2.2 \%$; it appears to exhibit a small decrease lower in the hole.

Thermal conductivity measurements yield an average value of $1.67 \pm 0.09 \mathrm{~W} / \mathrm{m}^{\circ} \mathrm{C}$. The measurements range from 1.47 to $1.87 \mathrm{~W} / \mathrm{m}^{\circ} \mathrm{C}$ and exhibit no correlation with porosity, density, or depth.

Seismic velocities average $5.75 \pm 0.30 \mathrm{~km} / \mathrm{s}$, with a range of 4.40 to $6.34 \mathrm{~km} / \mathrm{s}$, and show reasonable correlations with both wet bulk density and porosity; however, there is no obvious change in velocity with increasing depth.

\section{BASEMENT PALEOMAGNETISM}

Sites 501 and 504 lie on a positive magnetic anomaly that runs east and west, parallel to the crest of the Costa Rica Rift. At this place, such a positive anomaly signifies reversely magnetized crust, with a close relation between the nearly symmetrical anomalies and the causative blocks of crust. Since the inclination of the Earth's field at this latitude is low, secular variation is expected to produce excursions to both positive and negative inclinations through time, so polarity of magnetization cannot be determined from inclination. However, detection of a superimposed viscous component of magnetization of opposite polarity during alternating-current demagnetization often indicates reversed natural remanent magnetization in samples of low inclination. Such a viscous component was detected in the basalts of Sites 501 and 504, confirming the reversed polarity indicated by the anomaly. If the revised time scale of LaBrecque et al. (1977) is used, the age of the crust at the sites is 5.9 m.y.

A detailed account of the shipboard paleomagnetic measurements is given by Furuta and Levi (this volume). Briefly, the results are as follows. Twenty-eight minicores from Site 501 and 130 from Site 504 were measured for inclination before and after alternating-current demagnetization, for intensity of magnetization, and for susceptibility. Intensity of natural remanent magnetization $\left(J_{n}\right)$ showed a wide scatter of values, ranging from $0.1 \times 10^{-3}$ gauss to $30 \times 10^{-3}$ gauss. There is no systematic variation of $J_{n}$ with depth in the hole. $J_{n}$ is much more closely related to grain size, with higher $J_{n}$ values generally corresponding to the finer-grained basalts and lower $J_{n}$ to the more coarsely crystalline cores of massive flows. A suitable mean $J_{n}$ for both sites would be 5 to $10 \times 10^{-3}$ gauss, depending on the method of averaging.

Inclination after alternating-current demagnetization varies broadly with depth in the crust. In Hole 501 and the upper part of Hole 504B, inclinations are generally shallow, ranging from about $+10^{\circ}$ to $-20^{\circ}$, with a general bias to negative inclinations. Deeper in Hole 504B, inclinations become generally steeper, on the average, with the maximum positive inclination remaining close to $+10^{\circ}$, while negative inclinations reach $-60^{\circ}$ or $-80^{\circ}$ in parts of the core. The mean inclination is about $-10^{\circ}$ in the upper part of the hole and $-40^{\circ}$ near the bottom.

The ratio of remanent to induced magnetization $(Q)$ is generally high, as is usual in ocean floor basalts. It 
ranges from 0.1 to 108 , with a mean of about 10 , depending on the method of computation. The value of $Q$ is generally positively correlated with $J_{n}$, since the specific remanent intensity usually decreases, whereas susceptibility generally increases, with particle size.

Magnetic units were defined in Hole 504B on the basis both of $J_{n}$ and inclination after demagnetization. The latter proved to be a more powerful guide where inclinations are more variable (in the lower part of the hole). Nine units were defined in this way in the upper part of Hole 504B on Leg 69, and 15 units were defined in the lower part of the hole on Leg 70. Boundaries between magnetic units often correspond to the lithologic boundaries or zones of brecciation seen in the core.

Further discussion of these results and details of the shipboard measurements are to be found in Furuta and Levi (this volume).

\section{DOWNHOLE MEASUREMENTS AT SITES 501 AND 504}

\section{Logging}

Logging runs were made in Hole 501 and twice in Hole 504B, once at the end of Leg 69, when basement penetration was 214 meters, and again at the end of Leg 70 , when basement penetration had reached $561.5 \mathrm{me}-$ ters. The logs run at various times are listed in Table 3.

The porosity-related logs, such as compensated density, resistivity, neutron porosity, and sonic velocity, all agree in identifying very clearly the massive flow units and in showing the pillowed sections as being of higher and more variable porosity. Zones of very high porosity may be related to zones of faulting or brecciation in the hole. The caliper log showed the hole to be close to bit size throughout, but zones of relative enlargement of the hole occur, which may prove to be related to lithologic changes in the section. The natural gamma count is generally low, although there are small peaks (perhaps related to K-enrichment) in zones of oxidative alteration. A more complete discussion of the logging results can be found in Cann and Von Herzen (this volume).

\section{Temperature Measurements}

The Tokyo T-probe/pore water sampler was used to make four temperature measurements within the sediments in the high heat flow area, one in Hole 501 and three in Hole 504C. The results are discussed in detail in Becker et al. (this volume). The four temperature points define a steady increase in temperature with depth, with a decreasing gradient related to increasing thermal conductivity. When appropriately combined, the mean temperature gradient and average thermal resistance of the sediments indicate a heat flow of $194 \mathrm{~mW} \mathrm{~m}^{-2}$, a value in excellent agreement with the seafloor measurements made during the site survey work. These measurements show that the heat flow through the sediments is in conductive equilibrium. The value obtained is in good agreement with that theoretically expected in a crust aged 5.9 m.y. (Parsons and Sclater, 1977). The temperature indicated for the sediment basalt contact at Hole 504B is $56^{\circ} \mathrm{C}$.
A total of eight high-resolution temperature logs were made in three holes at Sites 501 and 504. Two profiles were measured in Hole 501, one 16 hours and the other $\mathbf{4 5}$ hours after drilling and circulation had stopped in the hole. Both curves are strongly affected by drilling disturbance, but some thermal recovery occurred during the 29 hours between measurements. Theory, such as that of Bullard (1947), predicts much faster recovery, indicating that Hole 501, like Hole 504B (Becker et al., this volume) was being chilled by a downward flow of seawater. Similar downflow has been indicated at three other DSDP sites (Sites 332, 396, and 456), which happen to be the only basement-penetrating sites at which adequate temperature measurements were made (Hyndman et al., 1976; Erickson and Hyndman, 1979; and Uyeda and Horai, 1982).

A temperature profile was measured in Hole 504A 28 days after it had been abandoned 12 meters into basement after bit failure. Re-entering the hole disturbed the temperature in the top 180 meters of the sediments, but in the lower 80 meters of the hole temperatures had nearly returned to equilibrium. The measured profile shows temperature near the bottom of the hole to be 2 to $3^{\circ} \mathrm{C}$ higher than in Hole $504 \mathrm{C}$, suggesting that heat flow may be somewhat higher at Hole 504A.

In Hole 504B, two temperature logs were made at the end of drilling on Leg 69 . Another log was run during Leg 70, 40 days after the last disturbance of the hole on Leg 69. Two more temperature logs were run during Leg 70 after the hole had been deepened to 561.5 meters into basement. The logs all indicate a significant downward flow of water in the hole to depths of 365 to 440 meters sub-bottom (90-170 $\mathrm{m}$ into basement). Below that level the close approximation of the measured gradient to that estimated by conductive theory strongly suggests that downward flow is insignificant. The existence of downward flow is most clearly demonstrated by the departure of the measured gradient from the conductive gradient established nearby in other holes even over a period longer than 1 month. The rate of downward flow can be estimated by using theory given by Jaeger (1961). On this basis, the profiles measured on Leg 69 indicate a downward velocity of 80 to 100 meters per hour (Becker et al., this volume).

At depths greater than about 440 meters sub-bottom, the logged temperatures, when corrected for drilling disturbance, fall on a uniform gradient of $0.12^{\circ} \mathrm{C} / \mathrm{m}$ down to depths of at least 800 meters sub-bottom. Thermal conductivity measurements on basement rocks yield a mean value of $1.7 \mathrm{~W} / \mathrm{m}^{\circ} \mathrm{C}$, which, when combined with the temperature gradient, gives a value of $204 \mathrm{~mW} \mathrm{~m}^{-2}$ for conductive heat flux. This is in excellent agreement with the measurements in the sediments and suggests a purely conductive in situ thermal regime over the whole section drilled.

The downward flow of water in the hole detected by the temperature measurements requires an in situ pressure within the basement that is significantly less than hydrostatic. Maintenance of the flow over long periods requires that this extend over a relatively large volume of crust. Both of these points are taken up in the next section. 


\section{Flow Tests with the Packer}

Flow tests were carried out with the Lynes packer at two levels in Hole 504B at the end of Leg 69, when the drill had penetrated 214 meters of basement (Zoback and Anderson, this volume). The packer was set 172.5 meters and 3 meters above the bottom of the hole. Therefore one test was within, and one below, the zone in which water was deduced to be flowing into the basement. The decay curves indicated permeabilities of 2 to 40 millidarcys.

Three other hydraulic characteristics of the basement were brought out by the tests. First, extrapolation of the pressure decay curves from the successful flow tests indicated a pore water pressure in the bottom of the hole at 214 meters into basement of 8 to 12 bars below hydrostatic. The existence of such a negative pressure had been predicted from the temperature measurements. Second, it proved to be possible to pump large volumes of water readily into the basement at only small overpressures (15 to 20 bars). Third, it was not possible to maintain excess pressures on the formation larger than 50 bars, even with the pumps running at maximum rate. This behavior probably resulted from the opening of existing cracks in the rock when the lithostatic load was exceeded, which occurred at overpressures of about 50 bars. The opening of the cracks greatly increases the permeability of the rock and thus limits the pressures that can be reached.

\section{DOWNHOLE WATER SAMPLING AND EXPERIMENTS IN HOLE 504B}

\section{Water Samples in Basement}

Basement water samples were collected with a Gearhart-Owen downhole sampler $(469 \mathrm{~m})$, the Lynes packer $(476 \mathrm{~m})$, and the Barnes in situ sampler $(460,640$, and $715 \mathrm{~m}$ ). All the samples collected were diluted to some extent by fresh surface seawater. Moreover, water pumped into the hole earlier reacted quickly and extensively with the basalts; hence, the samples recovered were actually mixes of fresh and reacted seawater only. No formation water was recovered (see Hart and Mottl, et al., this volume). Samples were collected from depths of $460,469,476,640$, and 715 meters below the seafloor $(185,194,201,365$, and 440 meters below the top of the basement). All the samples had $\mathrm{Ca}$ and $\mathrm{Si}$ concentrations greater than and $\mathrm{Mg}$ concentrations less than the surface or bottom water. The molar excess of $\mathrm{Ca}$ over bottom water values was the same as the molar deficiency of $\mathrm{Mg}$, just as observed in the sediment pore waters, suggesting that the reacted seawater quickly came to have $\mathrm{Ca}$ and $\mathrm{Mg}$ contents similar to the pore waters of the basal sediments, as would be expected if the chemical reactions of seawater within the basement controlled the composition of the sediment pore waters. The ratio between the excess of $\mathrm{Si}$ above bottom water and the excess of $\mathrm{Ca}$ above bottom water increases steadily with depth in the hole, reflecting an increase in $\mathrm{Si}$ in the reacted waters as the temperature increases with depth. This suggests that the reacted waters did not mix well vertically after they were pumped into the hole. The chemistry of waters sampled in basement is discussed in more detail in Mottl, Anderson et al. (this volume) and Hart and Mottl (this volume).

\section{Oblique Seismic Experiment}

The oblique seismic experiment (OSE) was proposed to study the detailed structure of Layer 2 in oceanic crust. Such an experiment was conducted at the end of Leg 70 in Hole 504B. In an OSE, the noise signal from shots fired at the surface at ranges up to $12 \mathrm{~km}$ are measured at an oceanic crustal borehole. The objectives of the experiment include (1) determining the lateral extent of the structure intersected by the hole; (2) analyzing the role of cracks in the velocity structure of oceanic crust; (3) detecting anisotropy in Layers 2 and 3; and (4) measuring attenuation in oceanic crust.

The shooting ship for the Leg 70 OSE was the R/V Gilliss, which sailed from and then returned to Panama (8 to 19 December 1979). During the experiment, the three-component geophone malfunctioned because of low-resistance shorts in the bulkhead connectors into the geophone and amplifier pressure cases (Stephen et al., 1980; and Stephen, this volume). The malfunctions could have been the result of connector faults or the high temperatures encountered in the hole. The net result was that rather than having three geophone signals (one for the vertical and two for the horizontal signal components), the three signals were mixed with one another. Consequently, only travel time information was collected; the amplitude data were meaningless.

The geophone was clamped at 3790 and $\mathbf{4 2 8 0}$ meters below the seafloor. At each depth a cross pattern of shots with lines oriented parallel and perpendicular to the spreading direction in the area was fixed. Shots were fired out to ranges of $12 \mathrm{~km}$ at a spacing of $0.5 \mathrm{~km}$. Three ocean bottom hydrophones were also deployed during the experiment to obtain data for comparison with the OCE data and to provide reverse profiles.

The travel time data are sufficient to determine the velocity structure in the upper 1500 meters of crust out to ranges of about $6.01 \mathrm{~cm}$ from the borehole. The comparison of these velocities with laboratory data, logging data, and regional seismic refraction surveys will constrain models of crack distribution in upper oceanic crust. Anisotropy was not observed in the travel time data, which had a resolution of approximately \pm 0.1 $\mathrm{km} / \mathrm{s}$. Since the amplitudes were not reliable, attenuation was not measured.

\section{Electrical Resistivity Experiment}

A relatively large-scale electrical resistivity experiment was carried out in Hole 504B after the completion of drilling on Leg 70. The experiment, which is described in detail by Francis (1982), utilizes a current electrode at the bottom of an insulated cable that is attached to a logging winch, with three voltage electrodes attached at variable spacings above. The current generated aboard the vessel is allowed to flow into the rock, and the voltage drops due to rock resistivity are recorded on board the ship. The resistivity structure in the basement sec- 
tion of Hole 504B was found to reflect the induction log resistivity, although it was somewhat attenuated in both magnitude and variation (Von Herzen et al., this volume).

\section{REFERENCES}

Anderson, R. N., and Hobart, M. A., 1976. The relation between heat flow, sediment thickness, and age in the eastern Pacific. J. Geophys. Res., 81:2968-2989.

Bullard, E. C., 1947. The time necessary for a borehole to attain temperature equilibrium. Mon. Notices, R. Astron. Soc. Geophys. Suppl., pp. 5 and 127.

CRRUST, 1982. Geothermal regimes of the Costa Rica Rift, East Pacific, investigated by drilling, DSDP-IPOD Legs 68,69 and 70 . Geol. Soc. Am. Bull., 93:862-875.

Erickson, A. J., and Hyndman, R. D., 1979. Downhole temperature measurements and thermal conductivities of samples, Site 396, Deep Sea Drilling Project Leg 46. In Dmitriev, L., Heirtzler, J., et al., Init. Repts. DSDP, 46: Washington (U.S. Govt. Printing Office), 389-400.

Francis, T. J. G., 1982. Large-scale resistivity experiment at Deep Sea Drilling Project Hole 459B. In Hussong, D. M., Uyeda, S., et al.,
Init. Repts. DSDP, 60: Washington (U.S. Govt. Printing Office), 841-852.

Hyndman, R. D., Von Herzen, R. P., Erickson, A. J., and Jolivet, J., 1976. Heat flow measurements in deep crustal holes on the MidAtlantic Ridge. J. Geophys. Res., 81:4053-4060.

Jaeger, J. C., 1961. The effect of the drilling fluid on temperatures measured in both holes. J. Geophys. Res., 66:563-569.

LaBrecque, J., Kent, D., and Cande, S., 1977. Revised magnetic polarity time scale for Late Cretaceous and Cenozoic time. Geology, 5:330-335.

Parsons, B. G., and Sclater, J. G., 1977. An analysis of the variation of ocean heat flow bathymetry with age. J. Geophys. Res., 82: 803-827.

Stephen, R. A., Louden, K. E., and Matthews, D. H., 1980. The oblique seismic experiment. In Donnelly, T., Francheteau, J., Bryan, W., Robinson, P., Flower, M., Salisbury, M., et al., Init. Repts. $D S D P, 51,52,53$, Pt. 1: Washington (U.S. Govt. Printing Office), 675-704.

Uyeda, S., and Horai, K., 1982. Heat flow measurements on Deep Sea Drilling Project Leg 60. In Hussong, D. M., Uyeda, S., et al., Init. Repts. DSDP, 60: Washington (U.S. Govt. Printing Office), 789-800.

Yokota, T., Kinoshita, H., and Uyeda, S., 1980. New DSDP (Deep Sea Drilling Project) downhole temperature probe utilizing IC RAM (memory) elements. Bull. Earthquake Res. Inst., 55:75-88. 

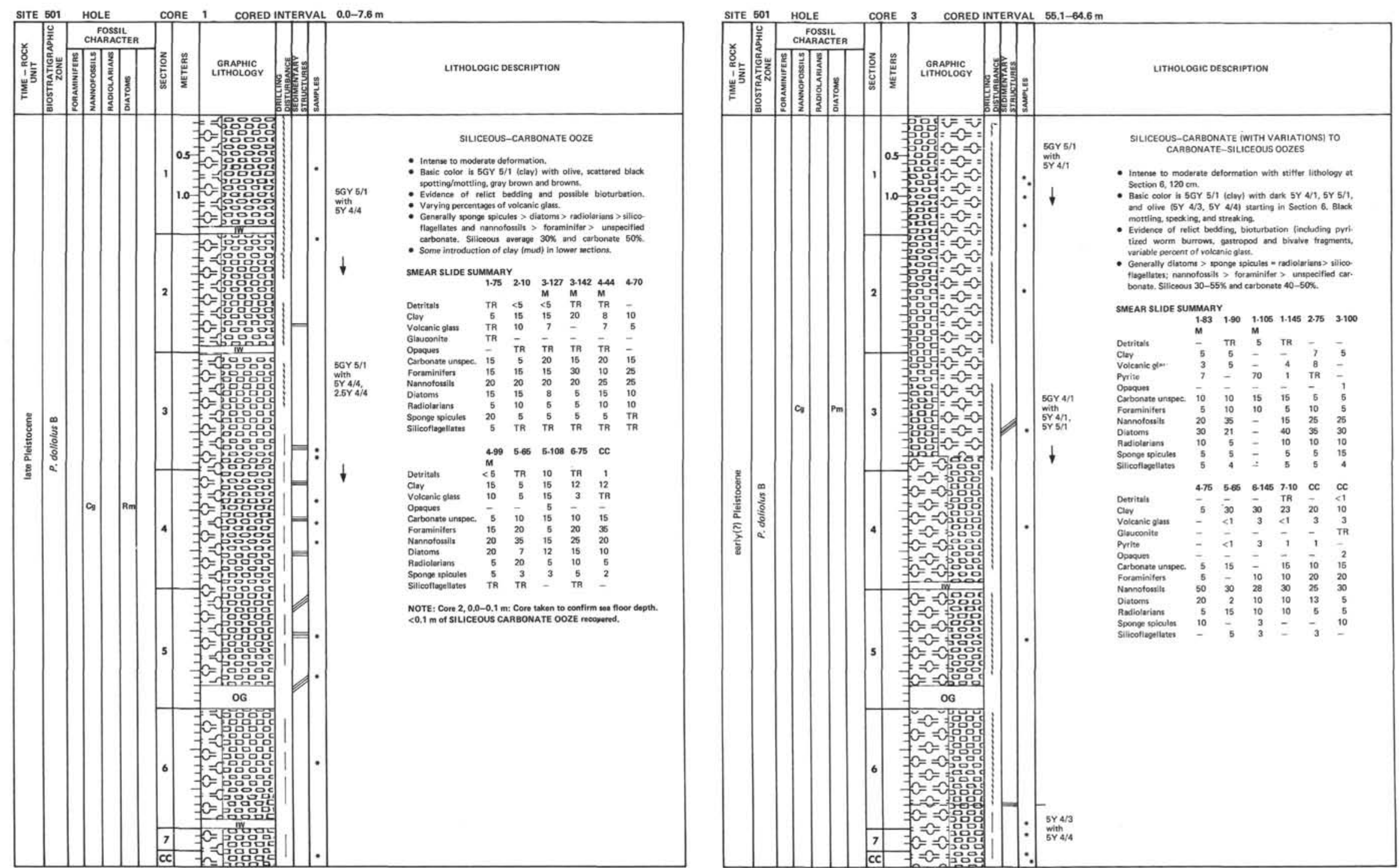

Information on core description sheets, for ALL sites, represents field notes taken aboard ship under time pressure. Some of this information has been refined in accord with postwith subsequent findings. Thus the reader should be alerted to the occasional ambiguity or discrepancy. 
ฌ

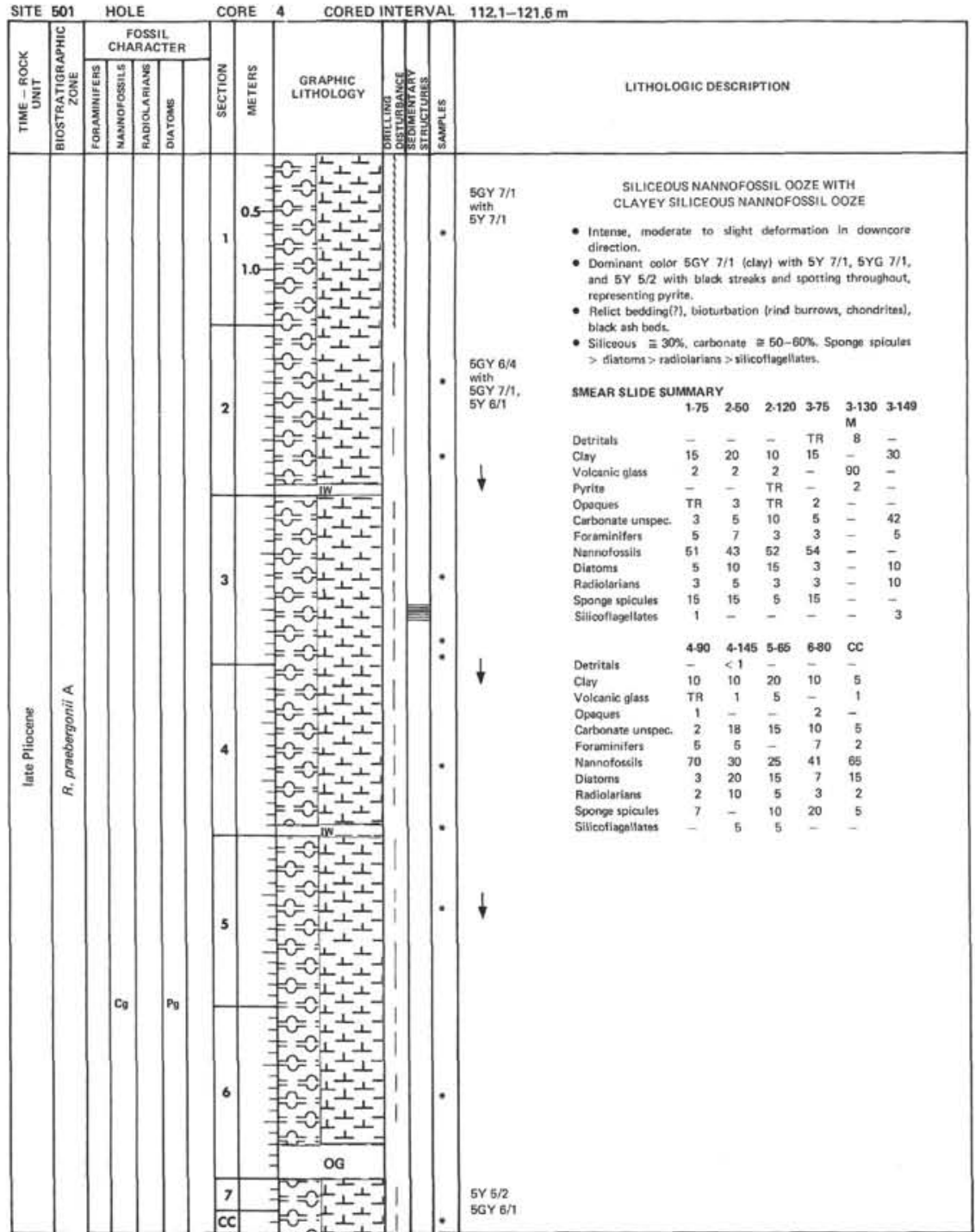

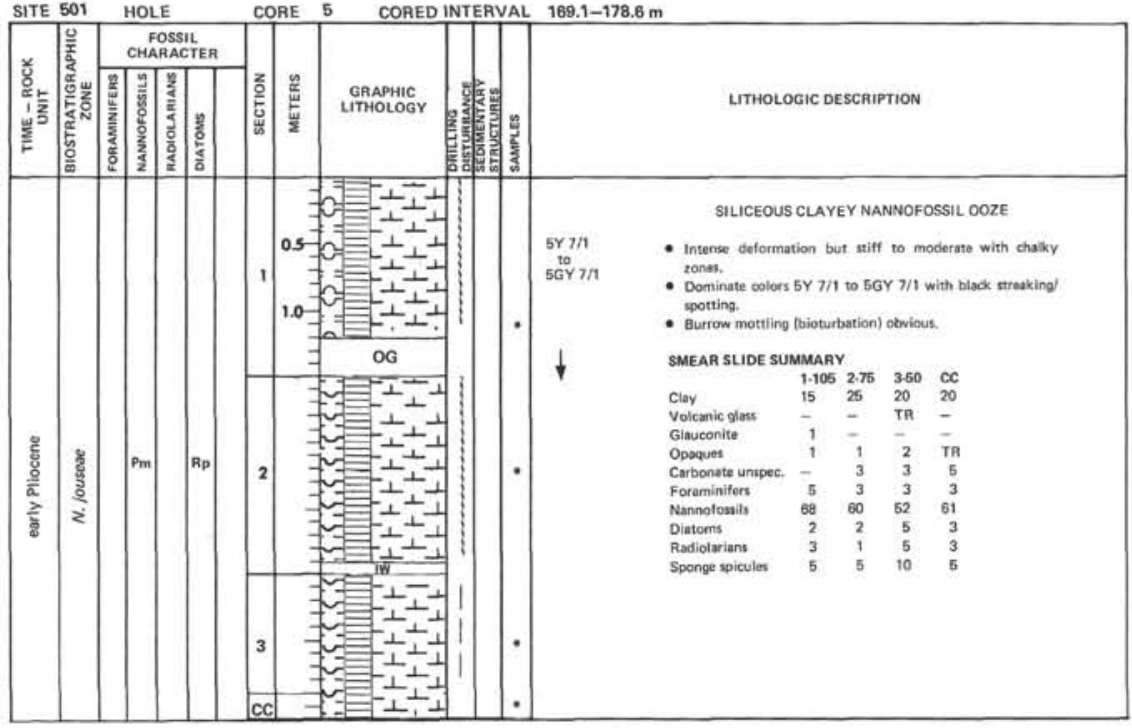

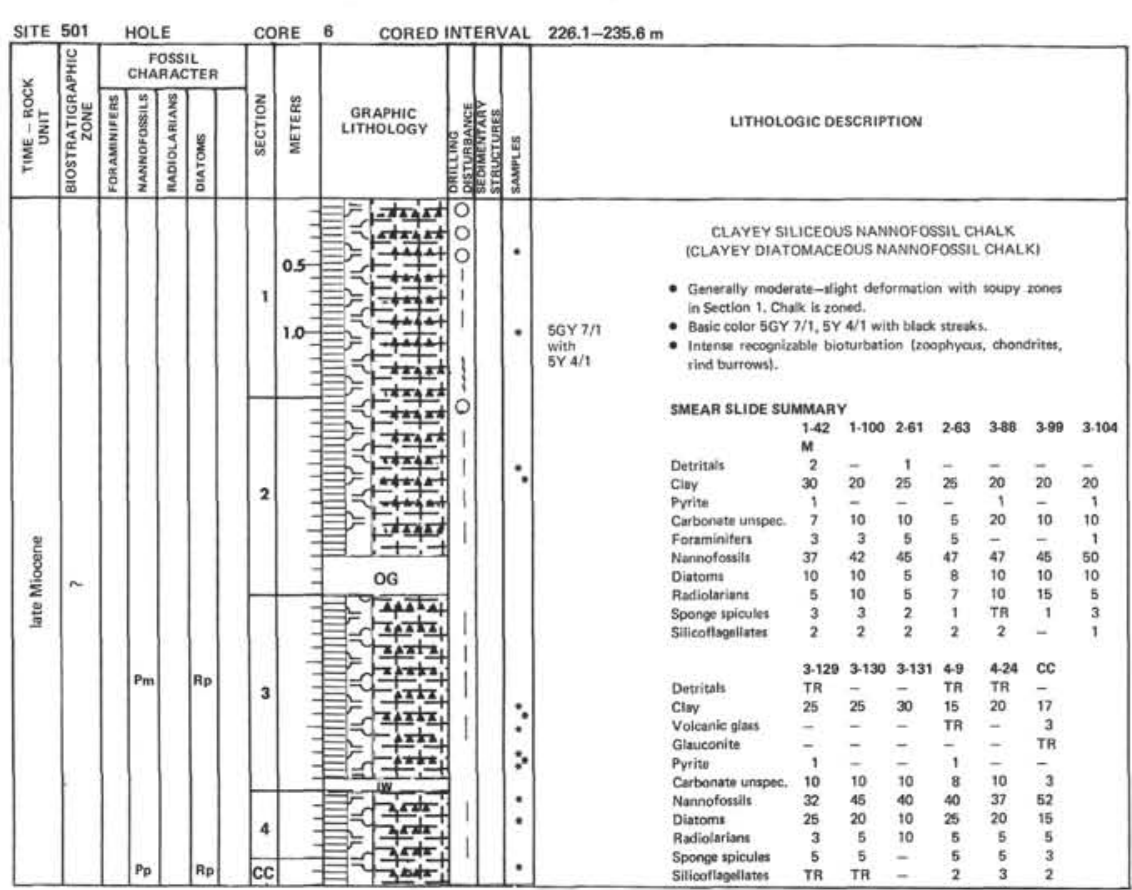



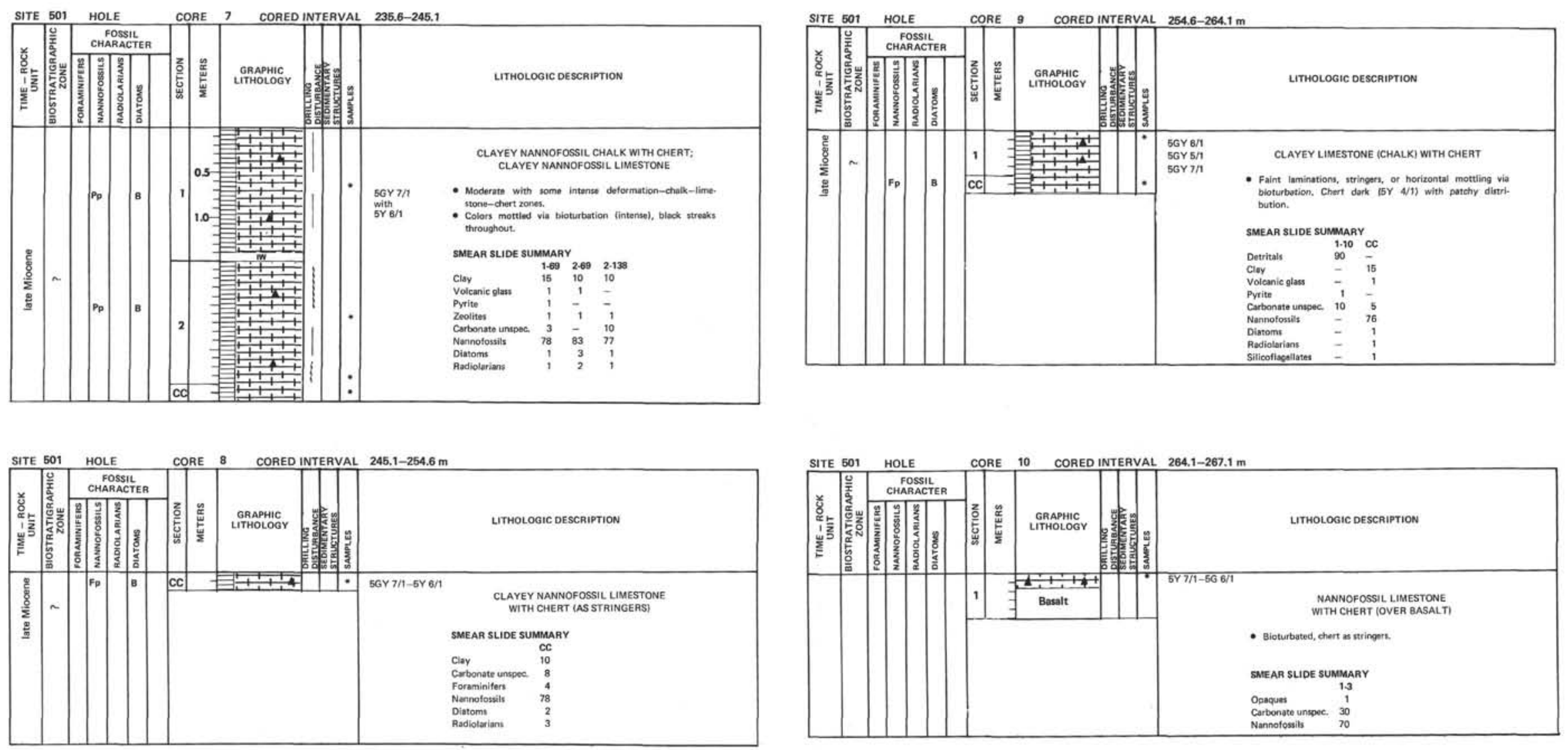


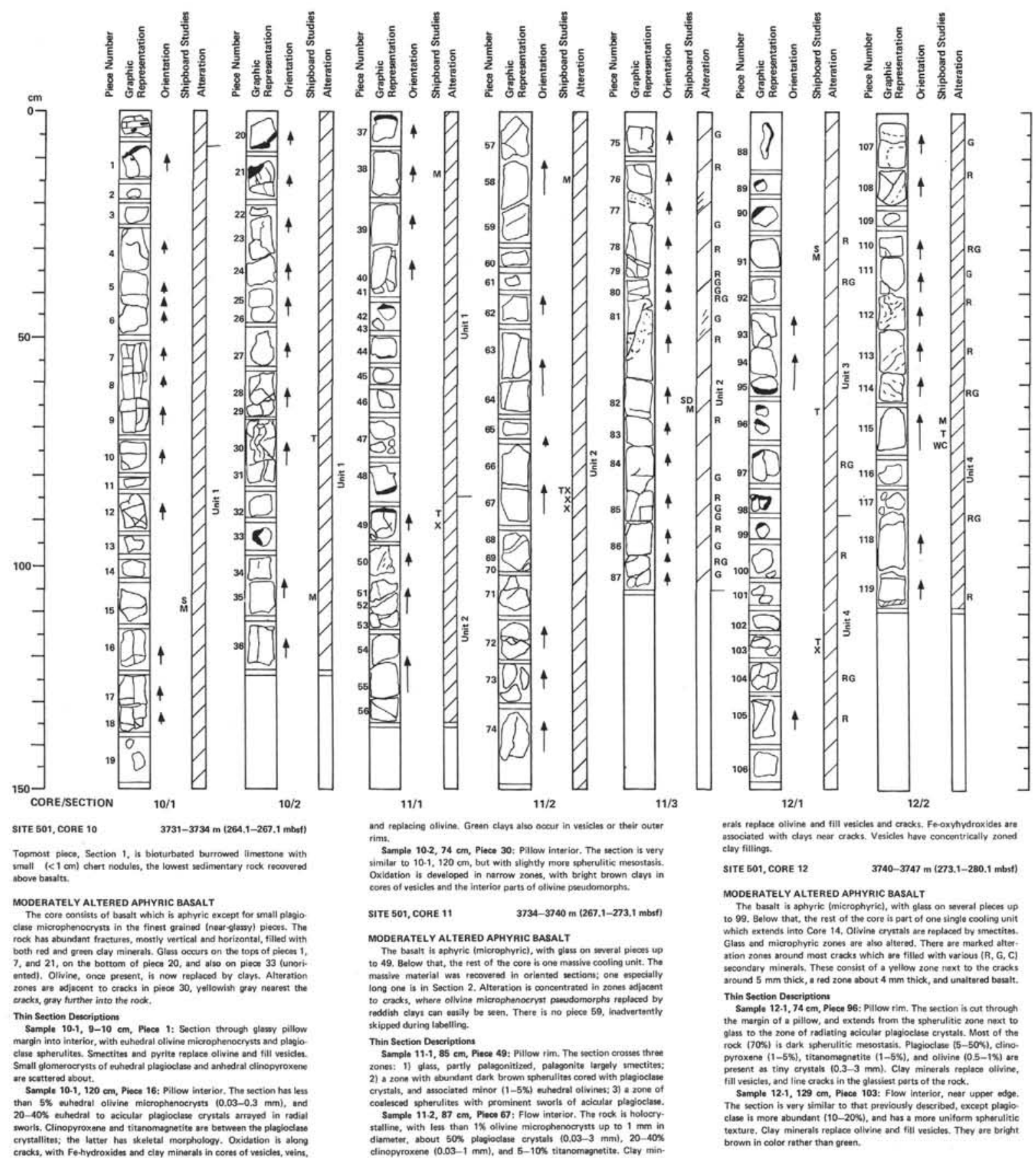

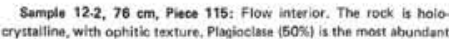

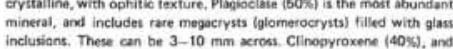

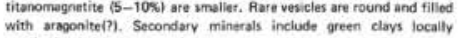

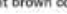

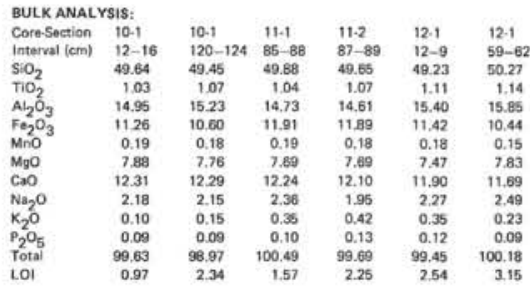

\begin{tabular}{|c|c|c|c|c|c|}
\hline \multirow{2}{*}{\multicolumn{6}{|c|}{ MAGNETIC DATA }} \\
\hline & & & & & \\
\hline 1. $75-77$ & 13.970 & -3.5 & & & \\
\hline $\begin{array}{l}0.1,103-110 \\
-2,16-18\end{array}$ & $\begin{array}{l}3.441 \\
3262\end{array}$ & & 1064 & & \\
\hline $\begin{array}{l}102,16-18 \\
11-1,14-16\end{array}$ & $\begin{array}{l}3.262 \\
2.748\end{array}$ & $\begin{array}{l}: 0.4 \\
0.3\end{array}$ & 16566 & & \\
\hline $112.16-18$ & $\begin{array}{l}2,7.78 \\
1.927\end{array}$ & $: 2.2$ & $\begin{array}{l}1560 \\
1560 \\
-10\end{array}$ & & \\
\hline $\begin{array}{l}11.3 .63-65 \\
12.30-7\end{array}$ & 3280 & +10.5 & 1536 & & \\
\hline $\begin{array}{l}12 \cdot 1,30-32 \\
12 \cdot 2,70-72\end{array}$ & $\begin{array}{l}1.310 \\
1.796\end{array}$ & $\begin{array}{l}-2.5 \\
0.1\end{array}$ & $\begin{array}{l}1904 \\
1712\end{array}$ & & \\
\hline & & & & & \\
\hline $\begin{array}{l}\text { re Section, interv } \\
\text { ritiog }\end{array}$ & & & GRAPE & Won: Bulk & \\
\hline & 5.427 & 5.197 & & & \\
\hline 118 & 5.56 & - & 3.03 & 2.91 & 3.42 \\
\hline $\begin{array}{l}-1.14 \\
-3.63\end{array}$ & $\begin{array}{l}6.57 \\
5.81\end{array}$ & 5.90 & $\begin{array}{l}202 \\
4.097\end{array}$ & - & E \\
\hline 63 & 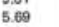 & & & & \\
\hline 30 & 56 & 5.51 & 283 & 2.84 & \\
\hline
\end{tabular}




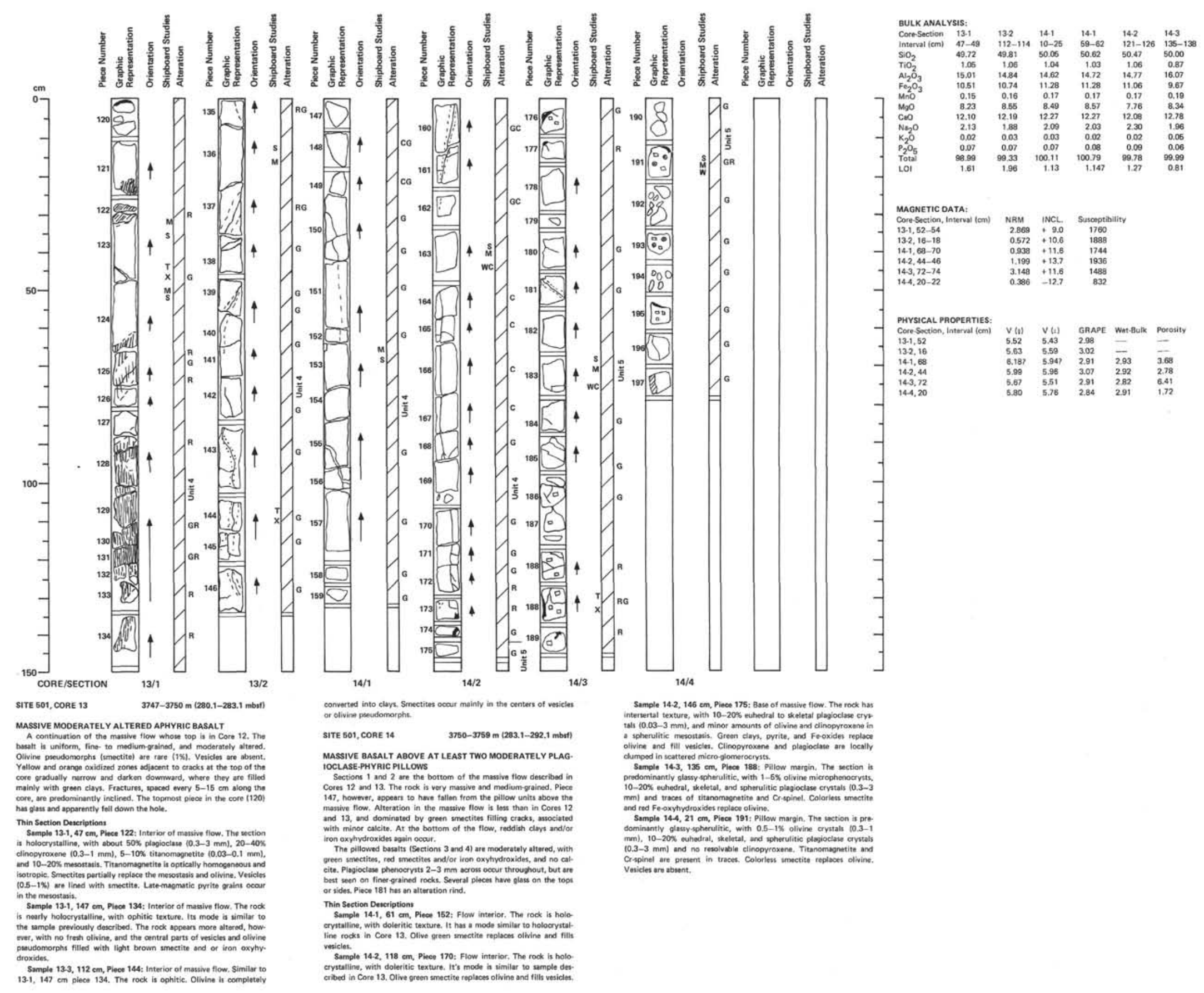




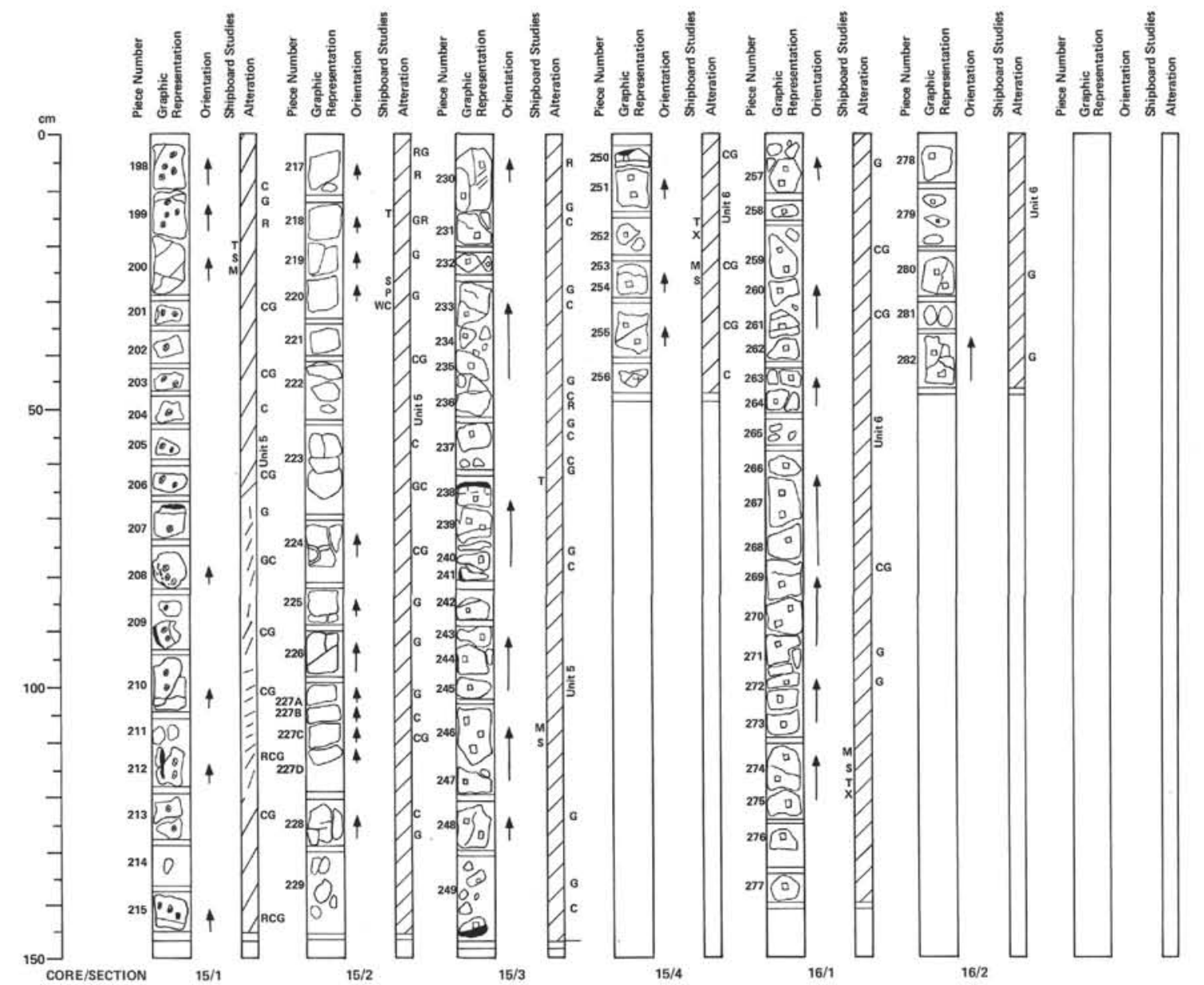

SITE 501, CORE 15 3759-3768 m (2921.-301.1 mbrt) SPAASELY
BASALTS

BASALTS
The rooss were very fine

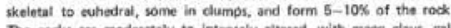

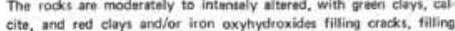
wesicles, and permeating the proundmust. Glass margins occur on the

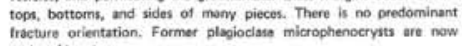
replaced by clary

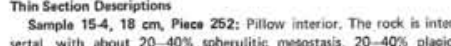

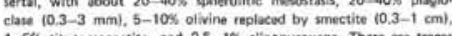
of Crspinat.

SITE 501, CORE $16 \quad 3768-3772 \mathrm{~m}$ (301.1-305.1 mbst SPARSELY PLAGIOCLASE-OUVINE PHYRIC BASALTS

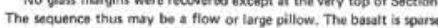

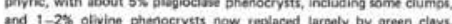
Along crocks there are oxidation zonet conistinino of yellow, brown

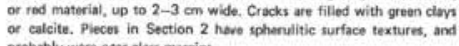
bly were near glass matrint

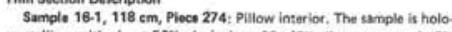

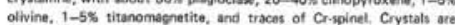

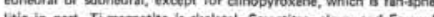
croxides replace olivine. The section cosseses an oxidation boundery in

BULK ANALYSIS:

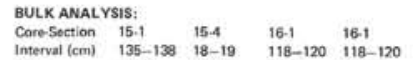

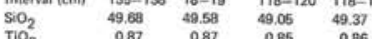

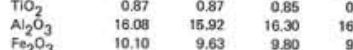

$\mathrm{MnO}_{3}$

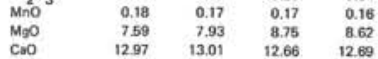

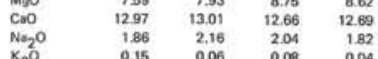

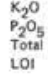

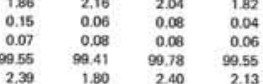

.

\begin{tabular}{|c|c|c|c|c|c|}
\hline & & & & & \\
\hline $\begin{array}{l}\text { Core Seetion, Interval (cm) } \\
15.122-24\end{array}$ & & & & & \\
\hline $\begin{array}{l}15.1,22-24 \\
15-2,28-30\end{array}$ & $\begin{array}{l}11.596 \\
11.318\end{array}$ & $\begin{array}{l}-16.2 \\
-18.8\end{array}$ & $\begin{array}{l}666 \\
464\end{array}$ & & \\
\hline $\begin{array}{l}15.3,100-108 \\
1530-108\end{array}$ & 21,148 & $\begin{array}{l}-18.8 \\
-10.6\end{array}$ & 573 & & \\
\hline $\begin{array}{l}154,28-30 \\
16-1,116-118\end{array}$ & 14.288 & +12.6 & 680 & & \\
\hline $16-1,116-118$ & 14.357 & -14.4 & 712 & & \\
\hline YSICAL PROPE & & & & & \\
\hline $\begin{array}{l}e^{2} \text { Section, Inter } \\
1.22\end{array}$ & & & GRAPE & & \\
\hline & $531 ?$ & $5.63 ?$ & 2.63 & 284 & \\
\hline $15-3,106$ & $\begin{array}{l}8.107 \\
6.097\end{array}$ & $\begin{array}{l}6.657 \\
6.337\end{array}$ & 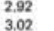 & $\begin{array}{l}2.87 \\
2.84\end{array}$ & \\
\hline $\begin{array}{l}15-4,28 \\
18.116\end{array}$ & $5.98 ?$ & 6.327 & 2.79 & 2.75 & 20 \\
\hline & & & & & \\
\hline
\end{tabular}




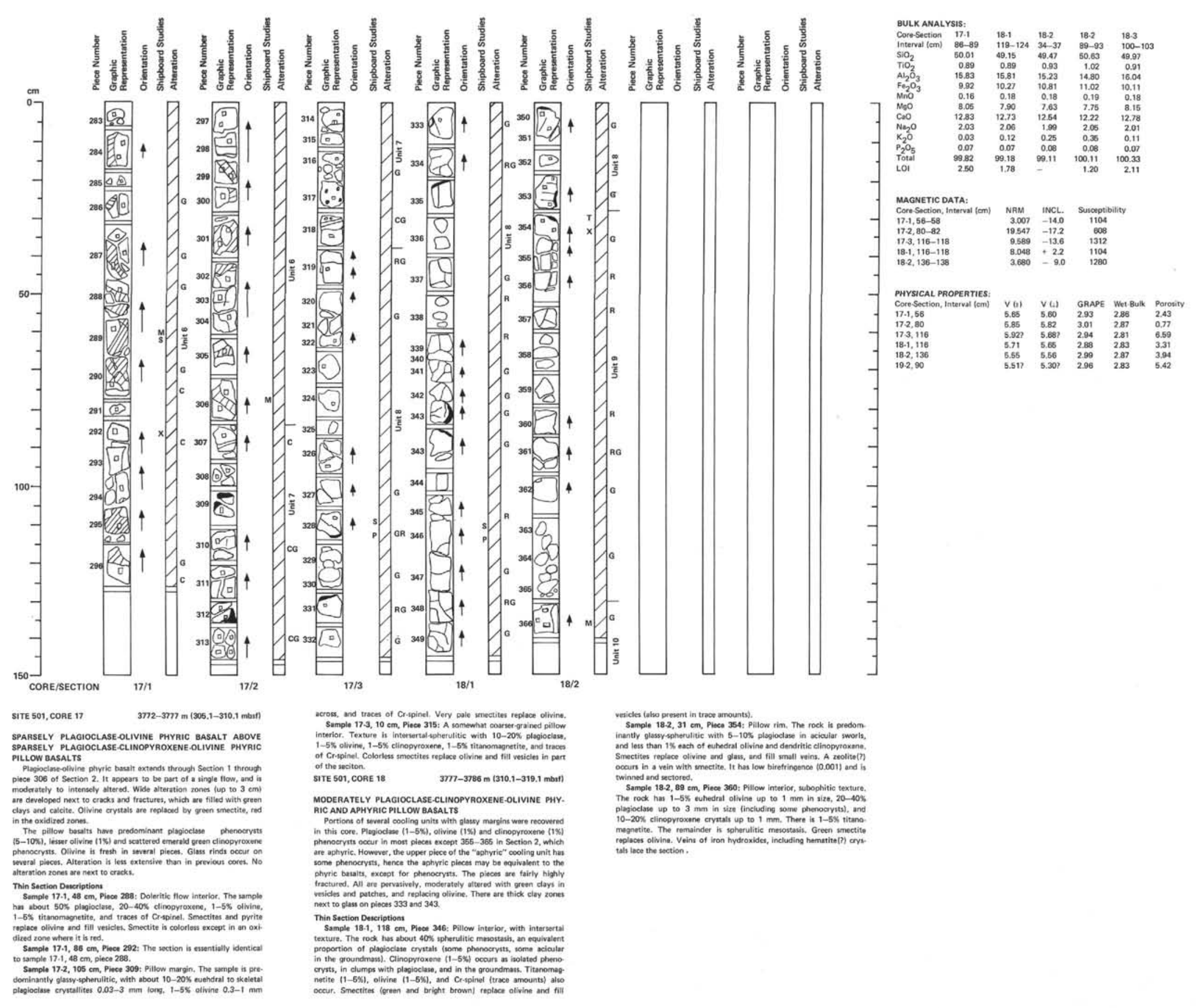




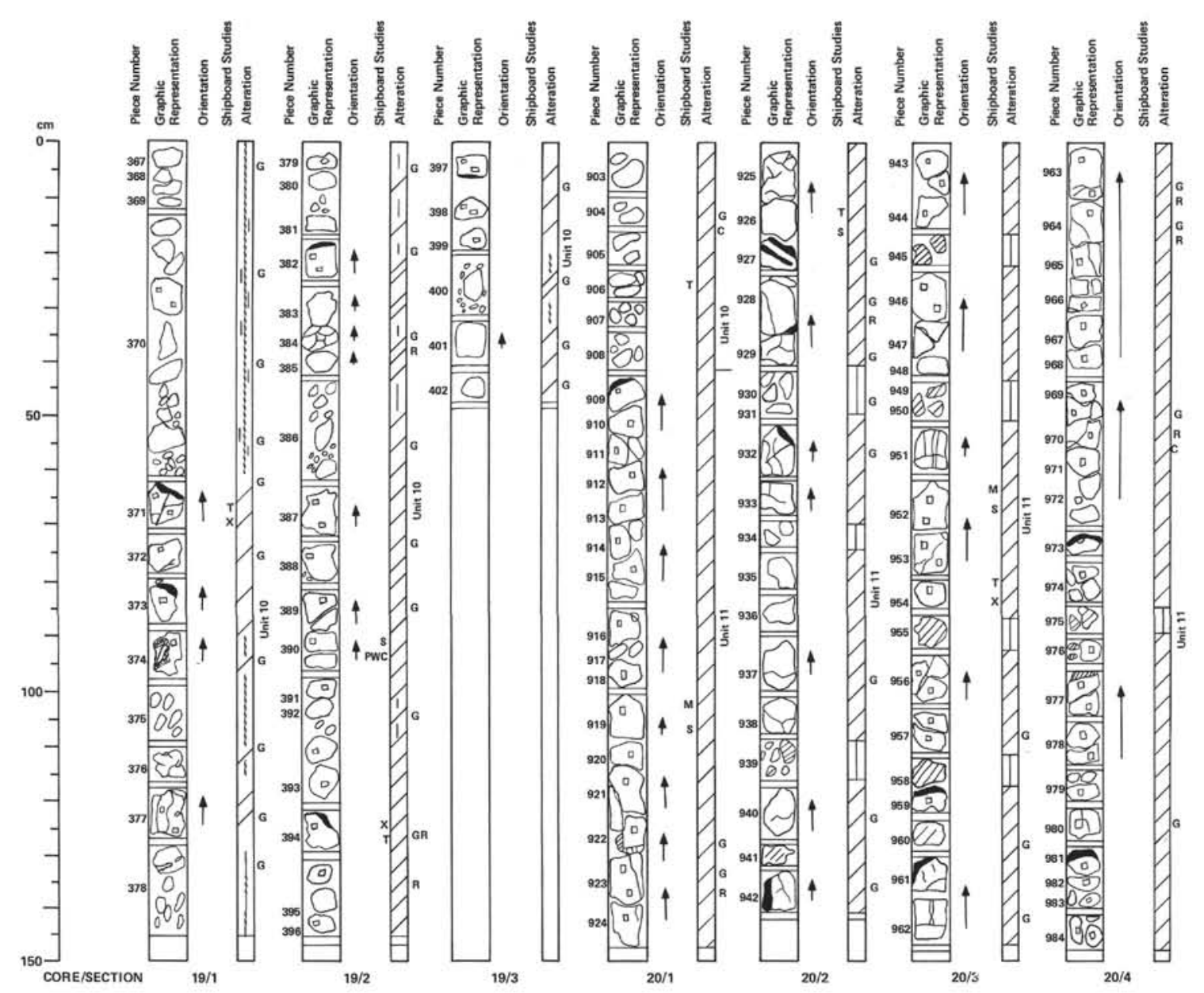

SITE 501, CORE 19

MOOERATELY TO INTENSELY ALTERED PLAGIOCLASE.
OLIVINE.CLINOPYROXENE MODERATELY PHYRIC PILLOW

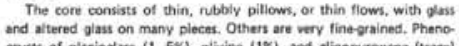

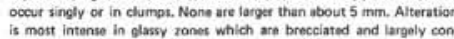

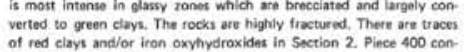

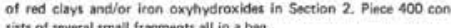

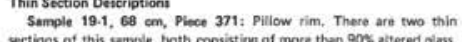

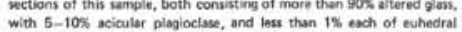

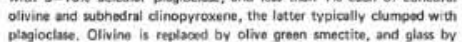

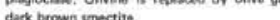

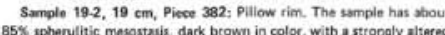

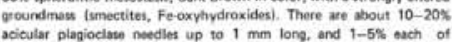

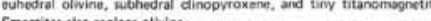
SITE 501, CORE 20 3785-3794 m (328.1-337.1 mbat) SPARSELY PLA
PLLLW BASALT

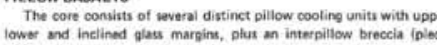

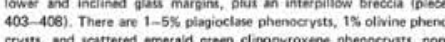

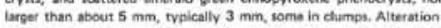

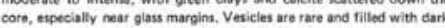

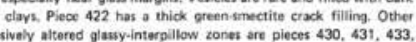
$439.445,450,45$, and 458 .

BULK ANALYSIS:

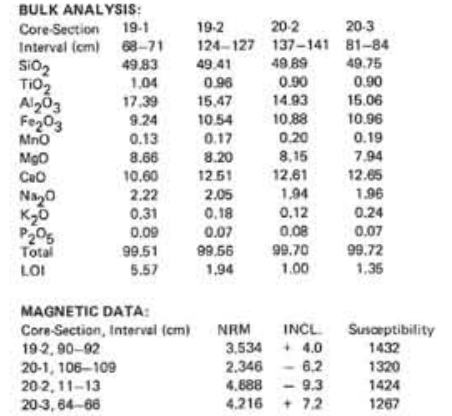

PHYSICAL PROPERTIES:

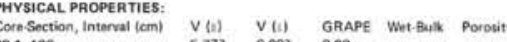

$20,2,11$

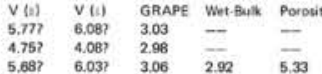



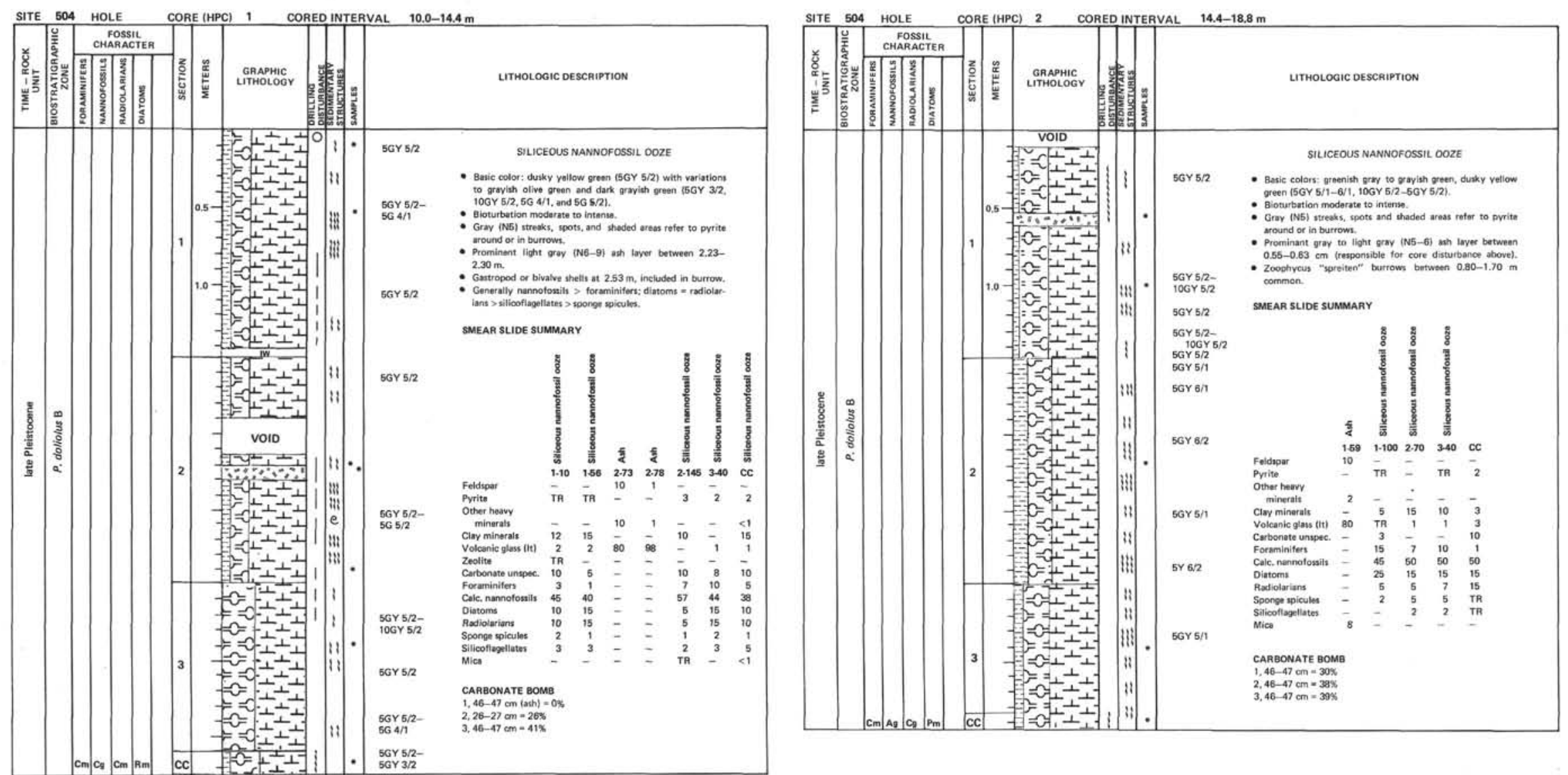
$\sigma$

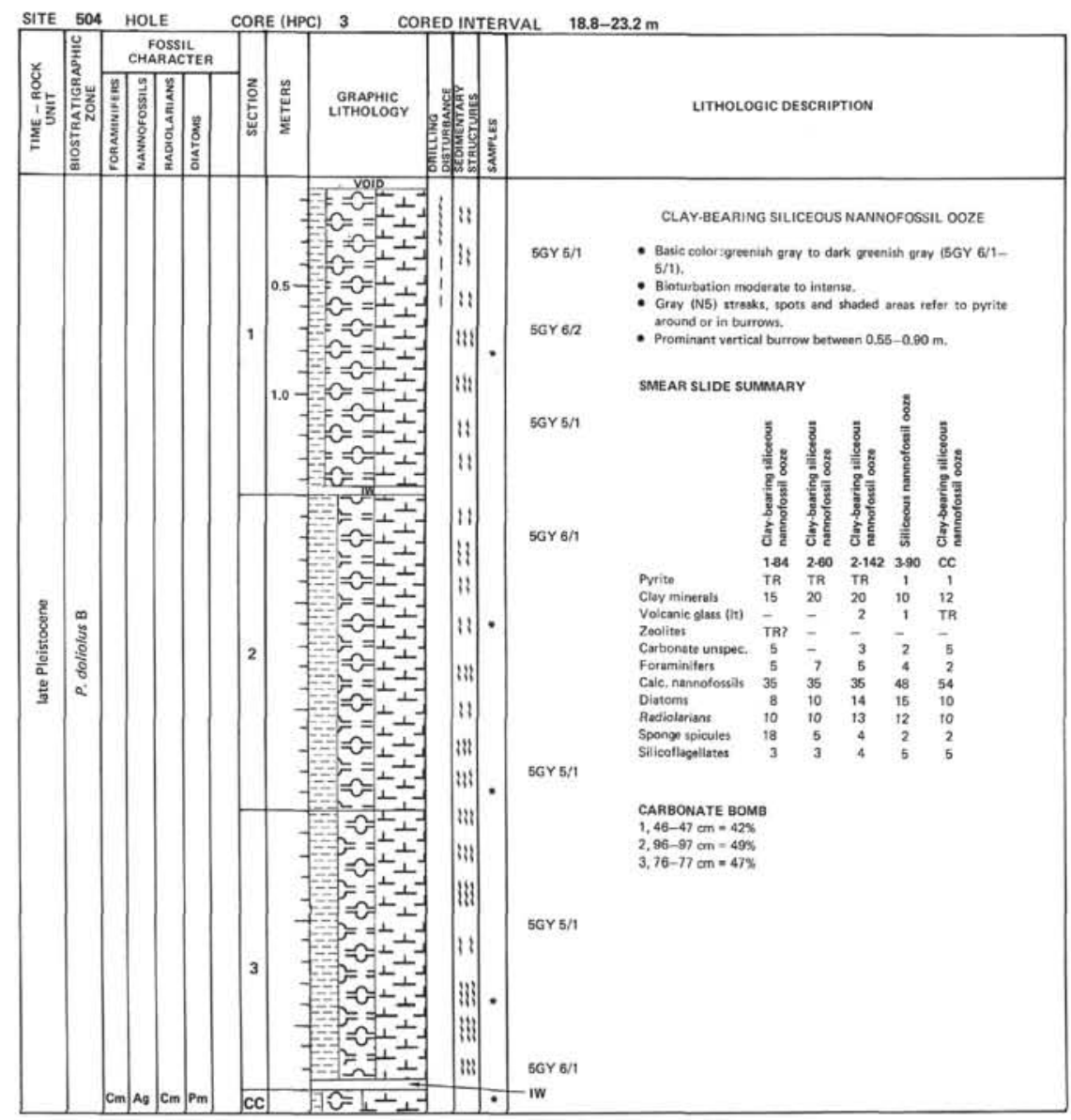

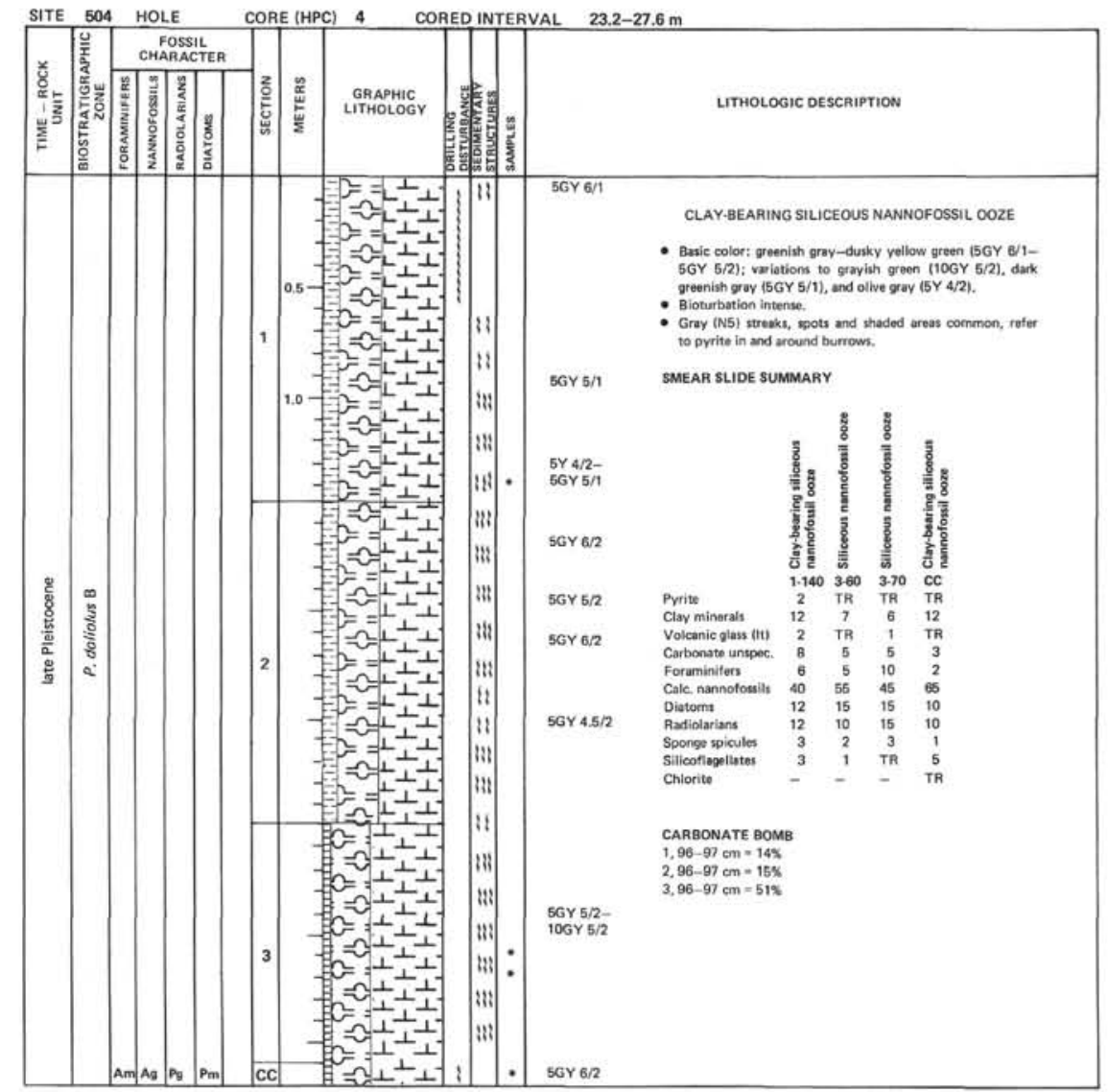



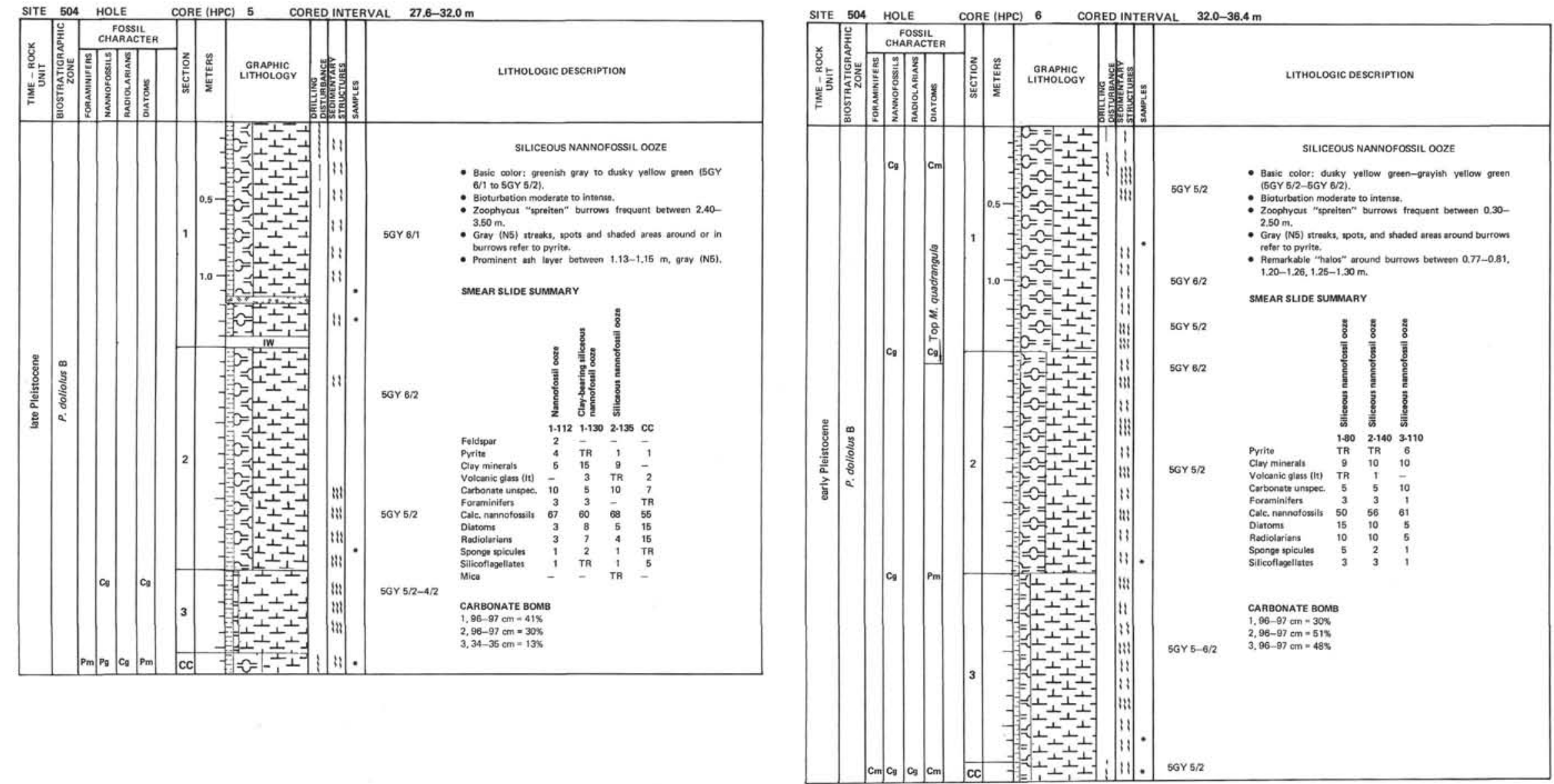

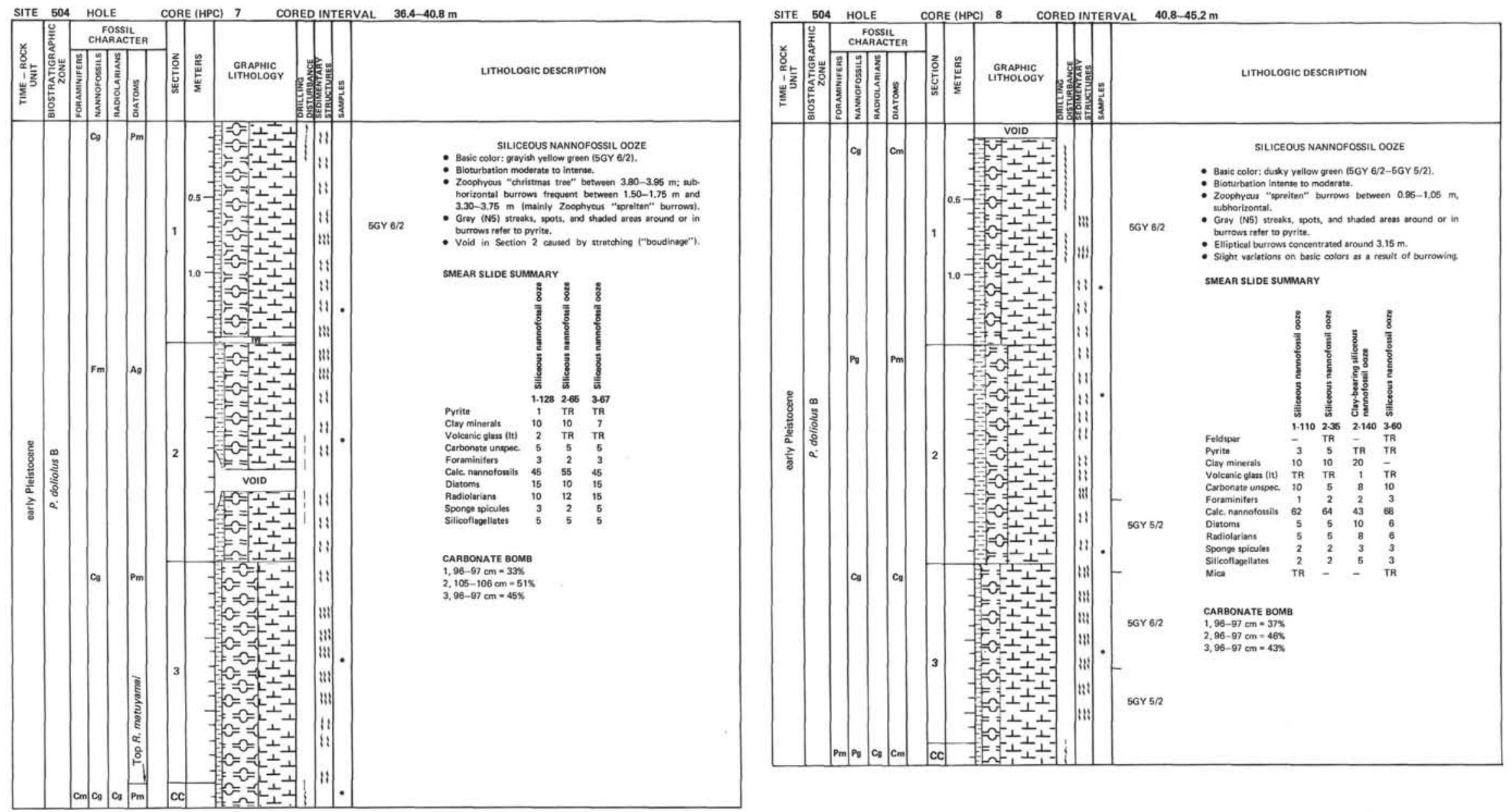

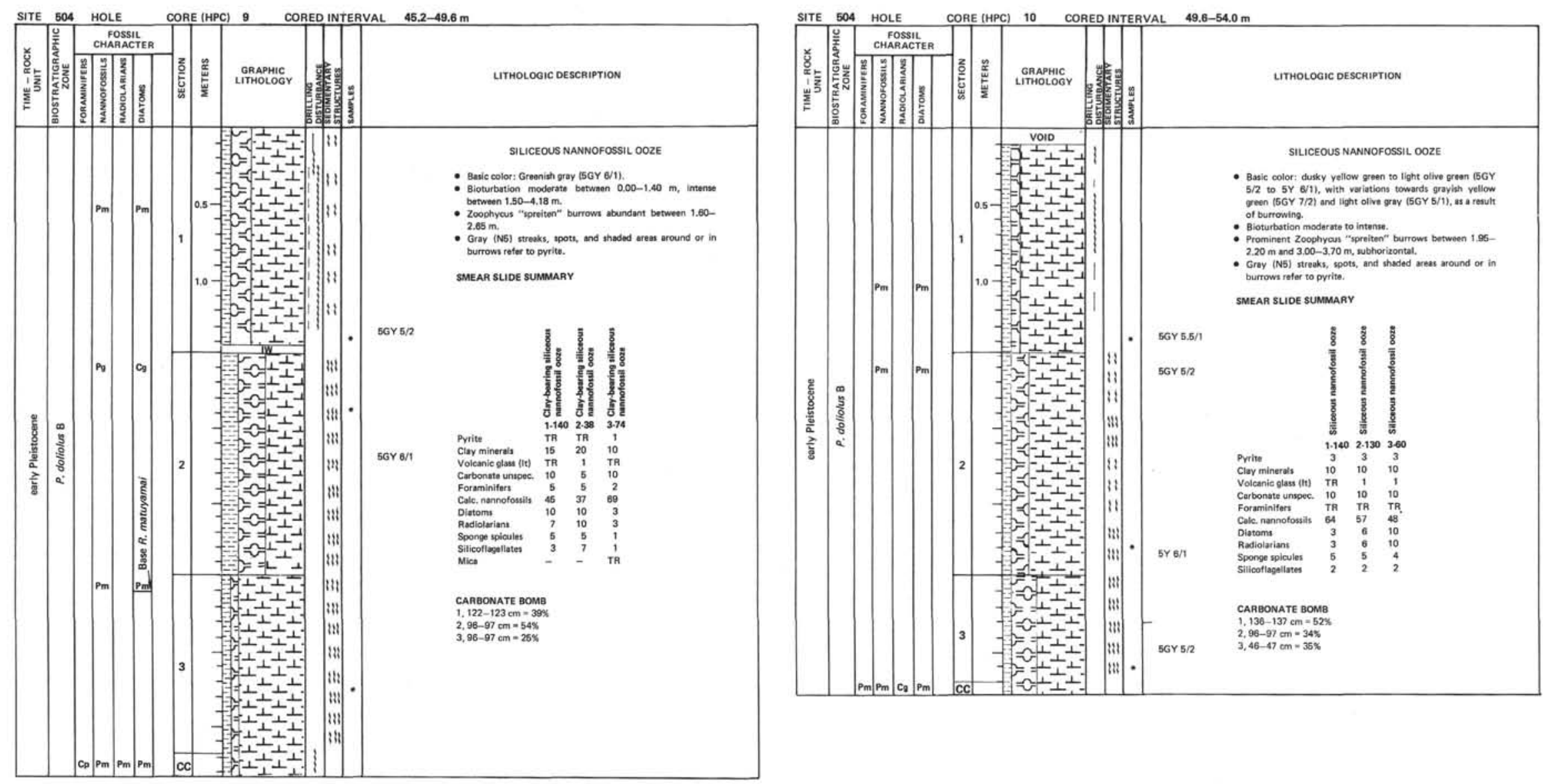

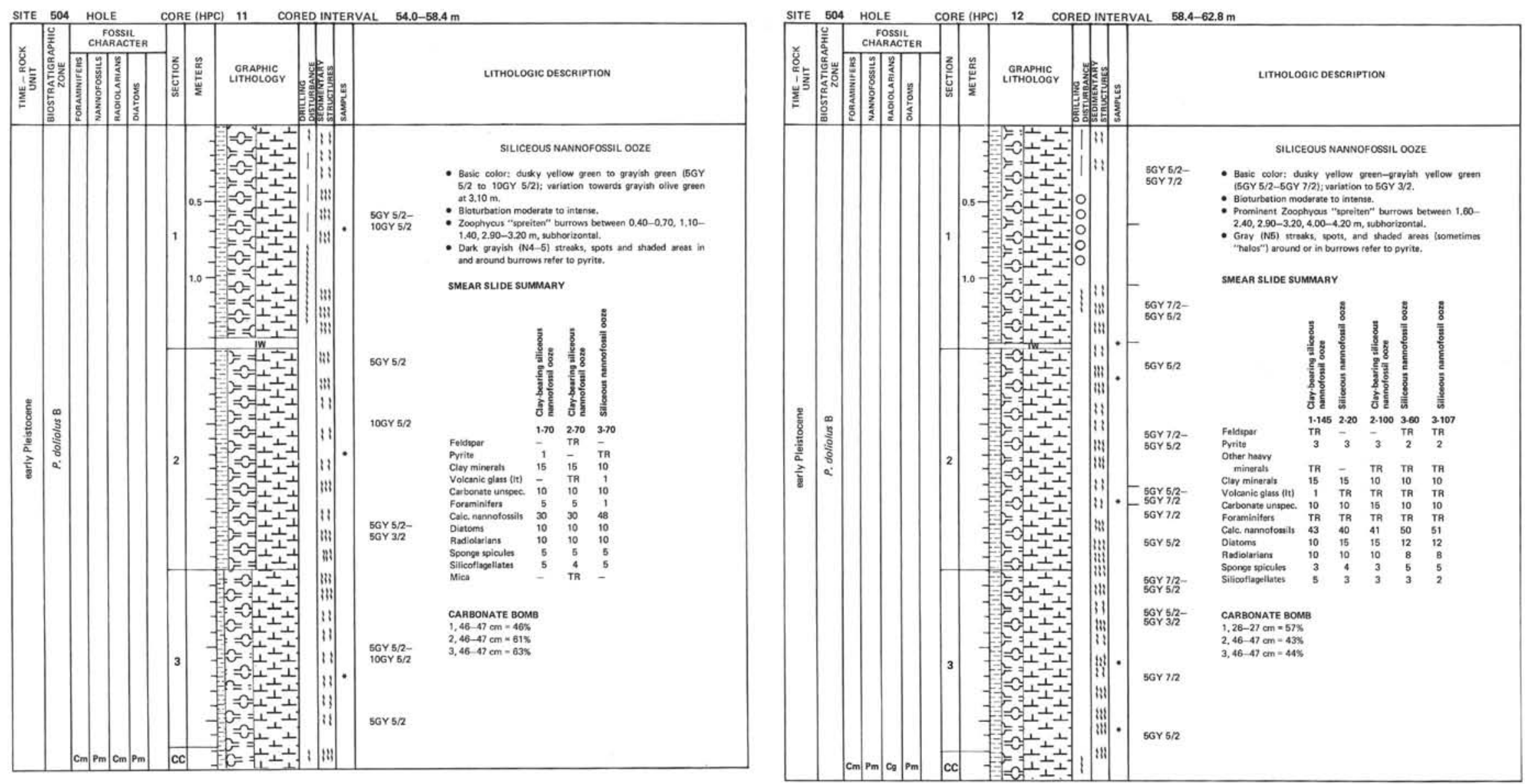

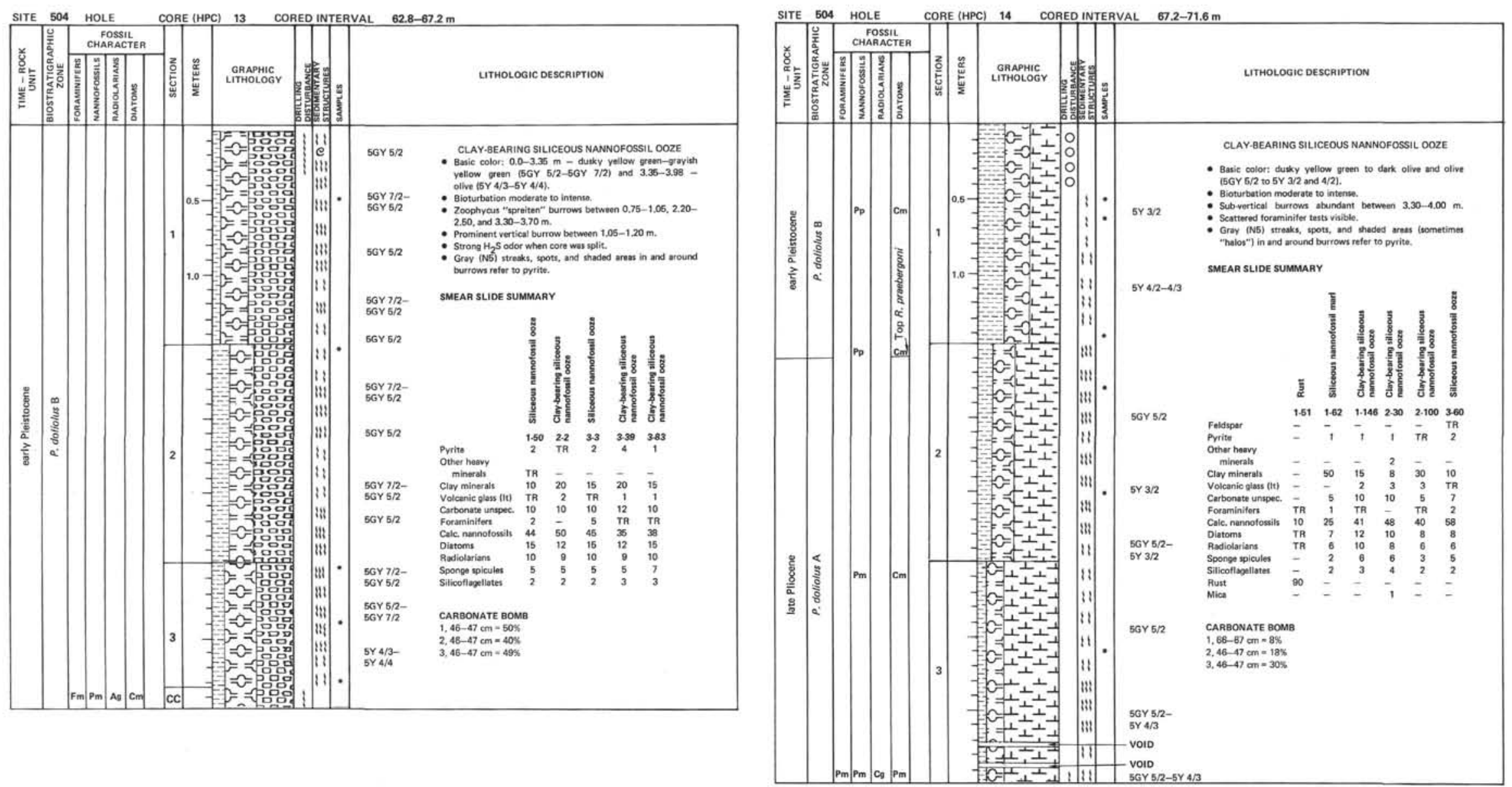

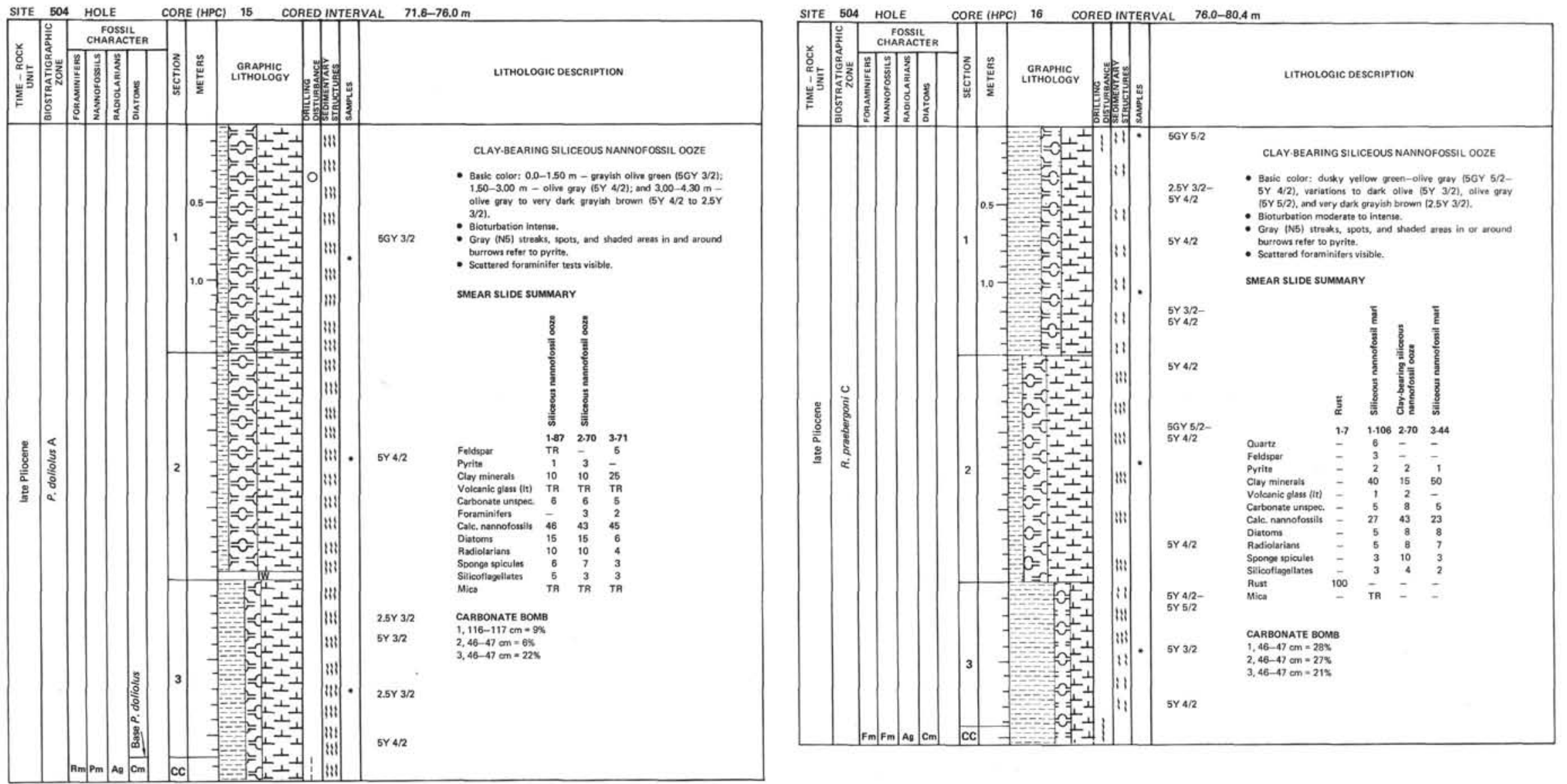


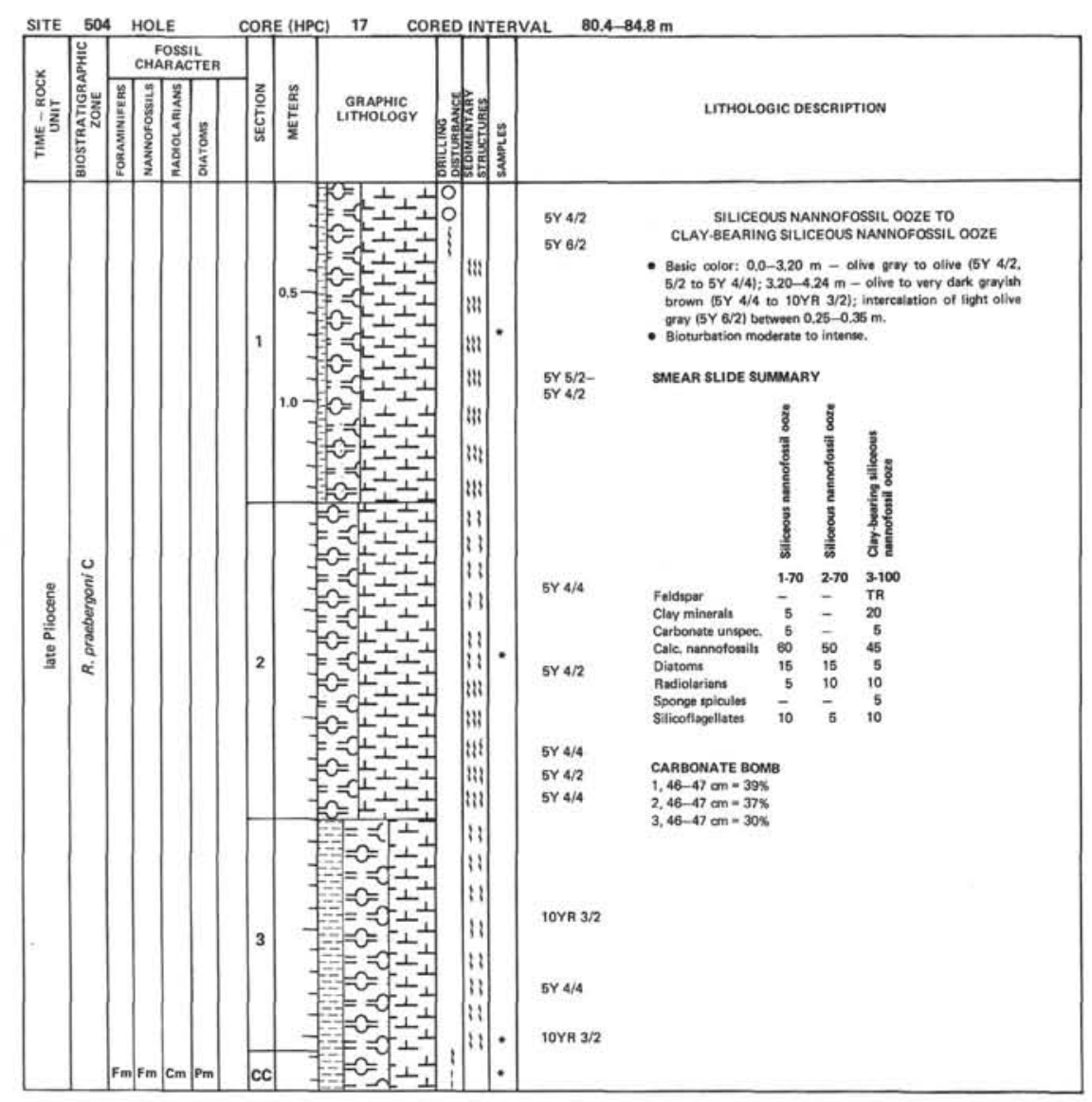

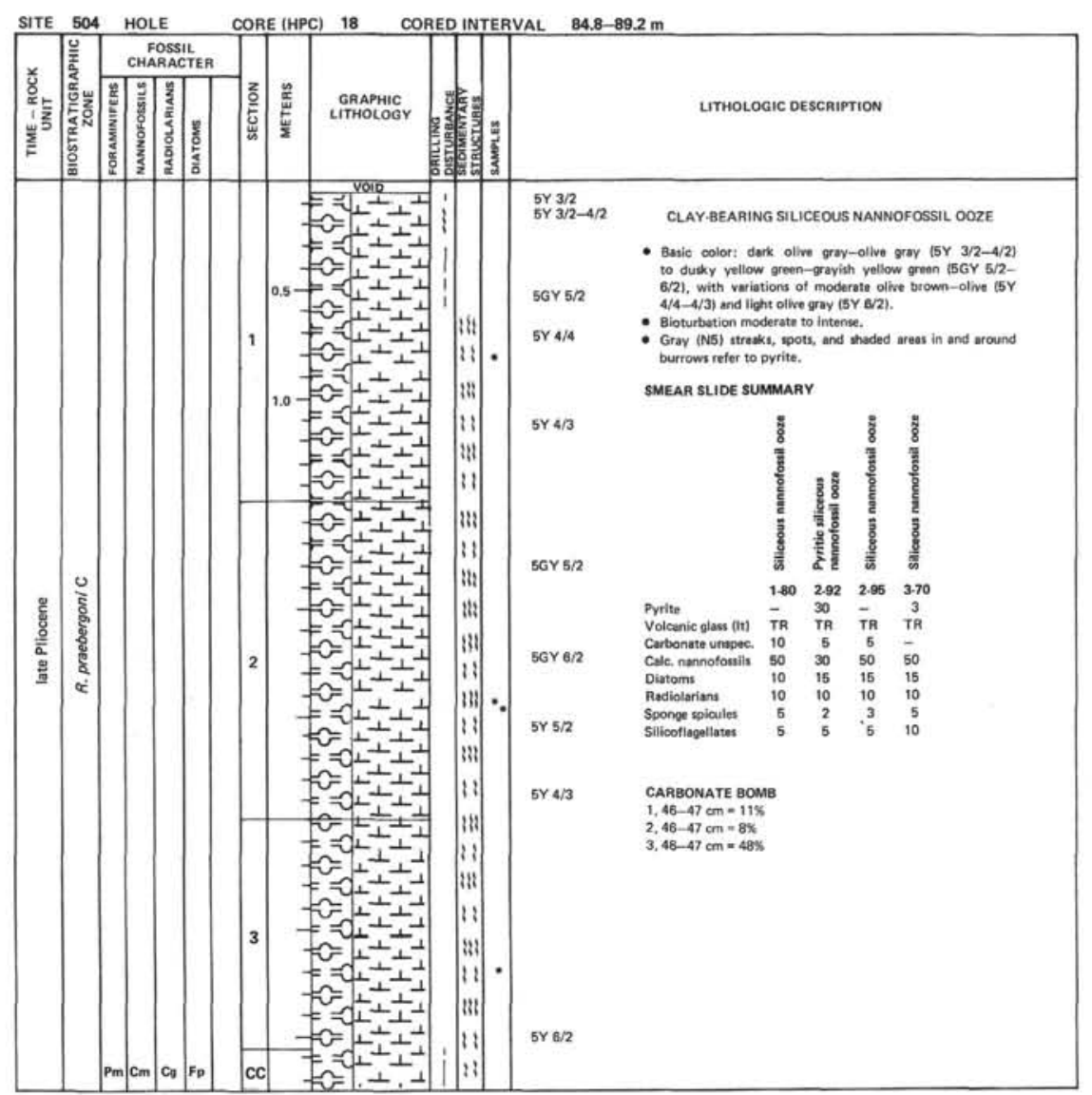



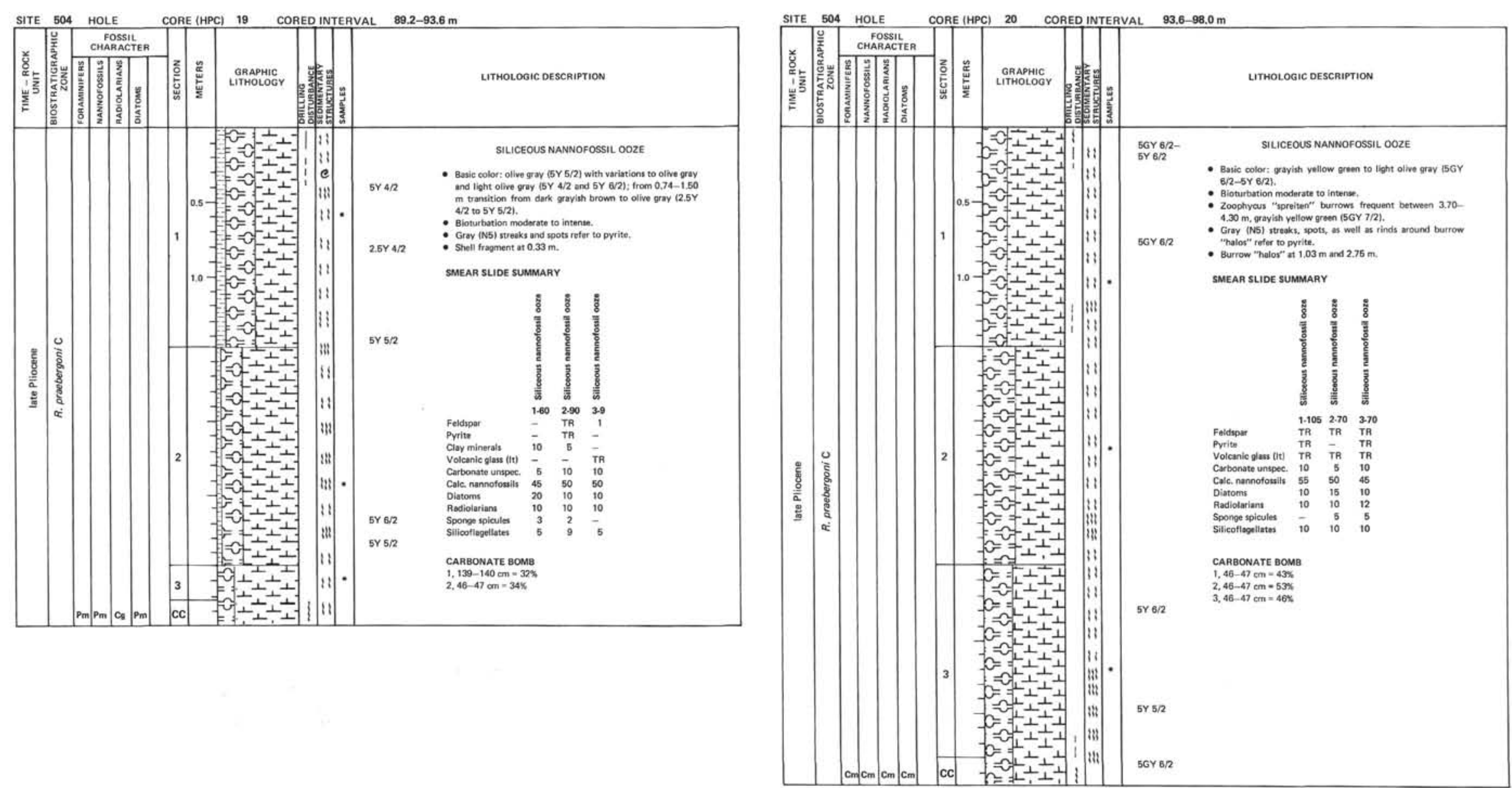


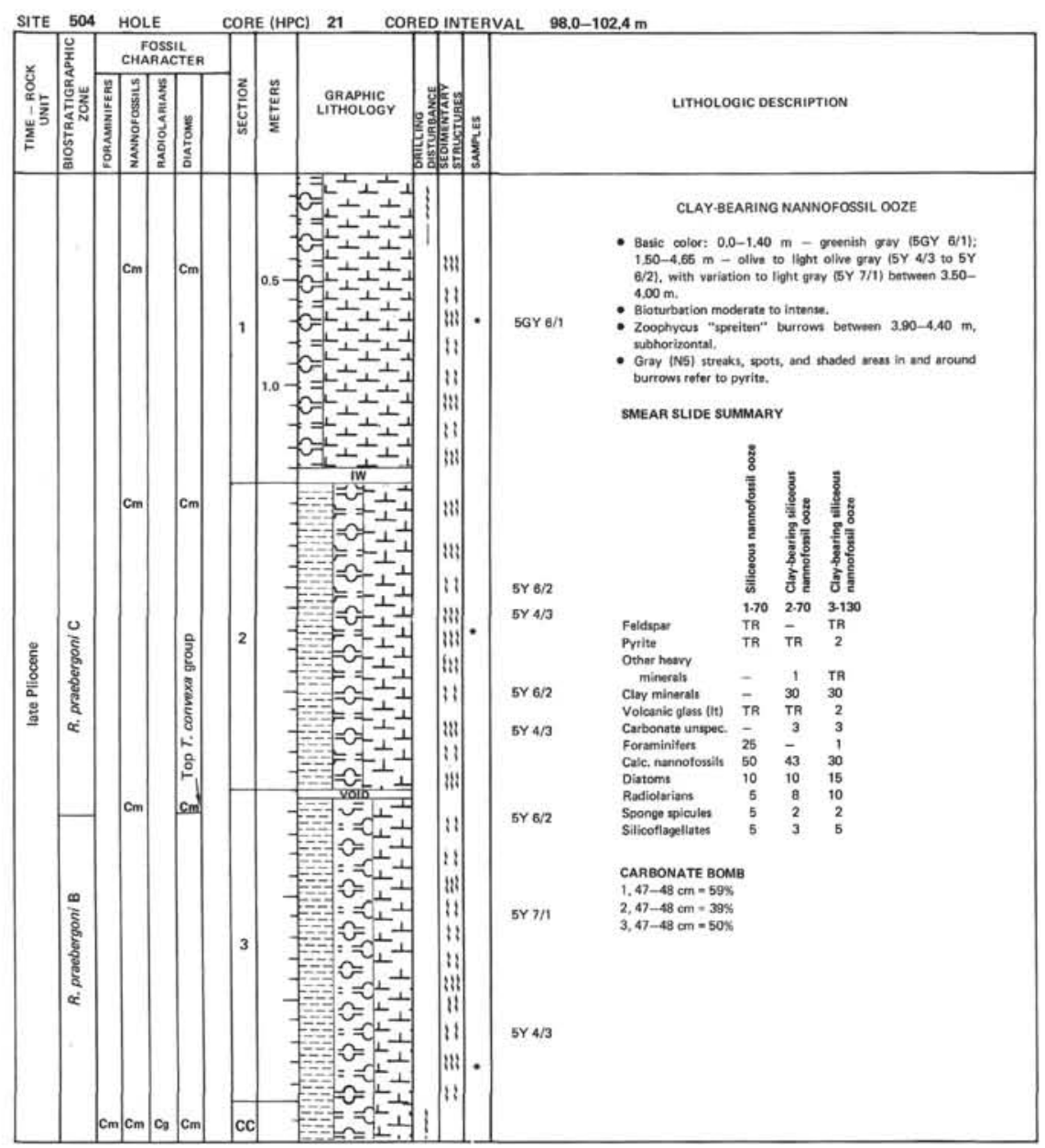

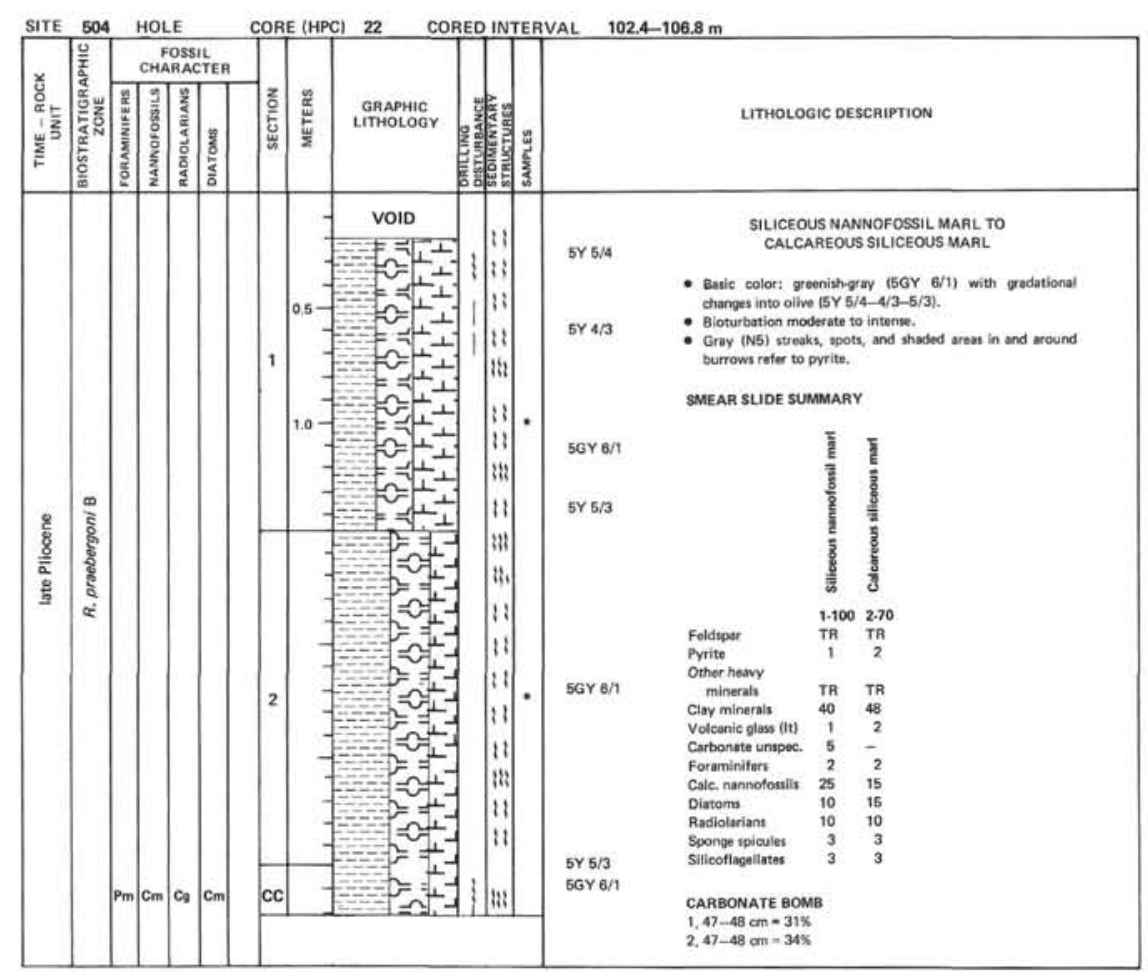



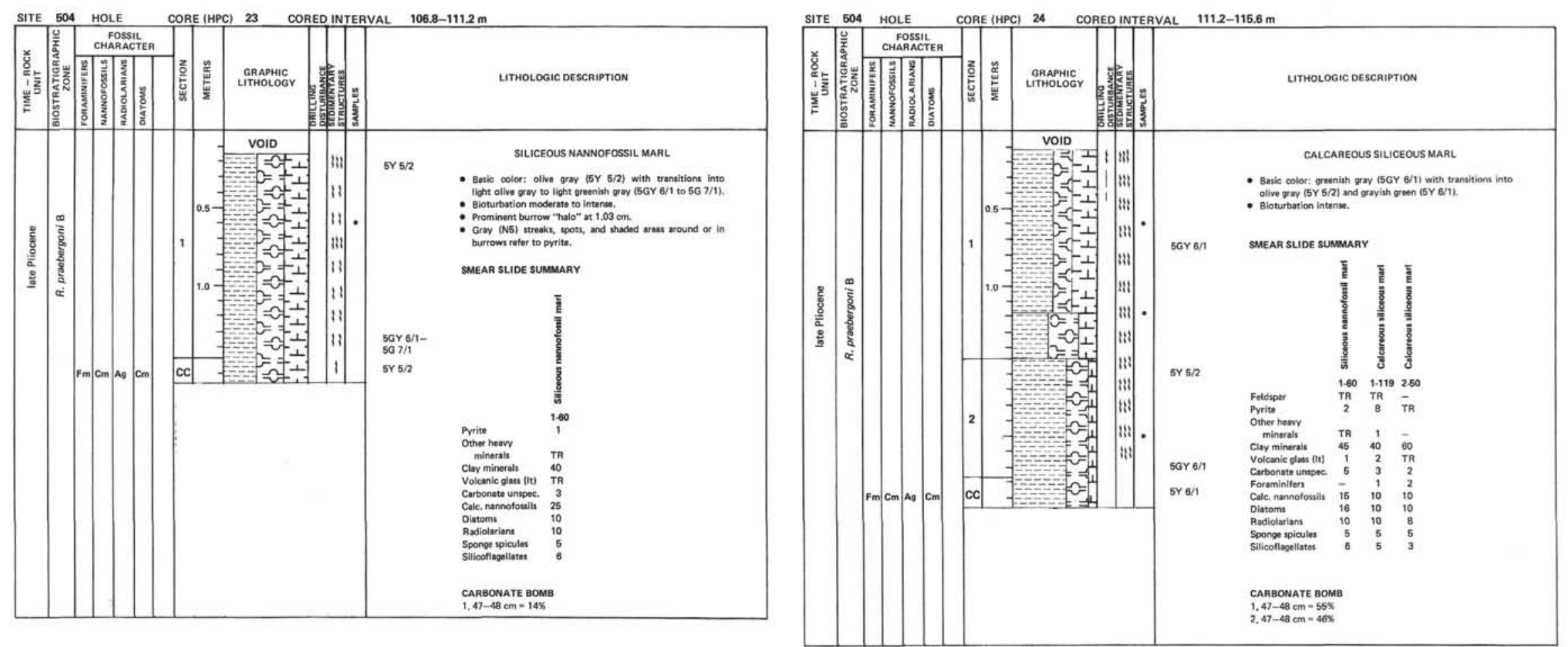

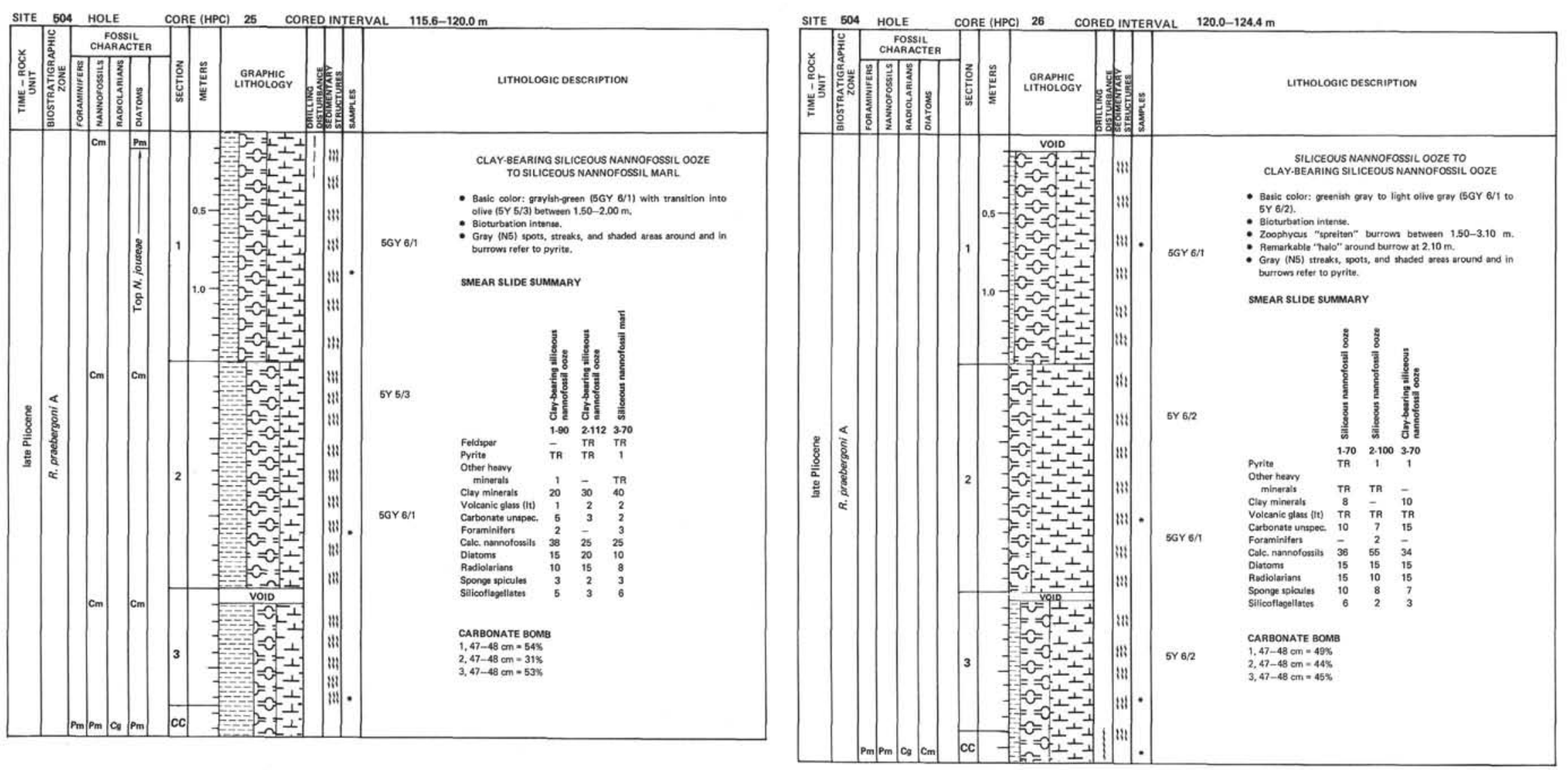

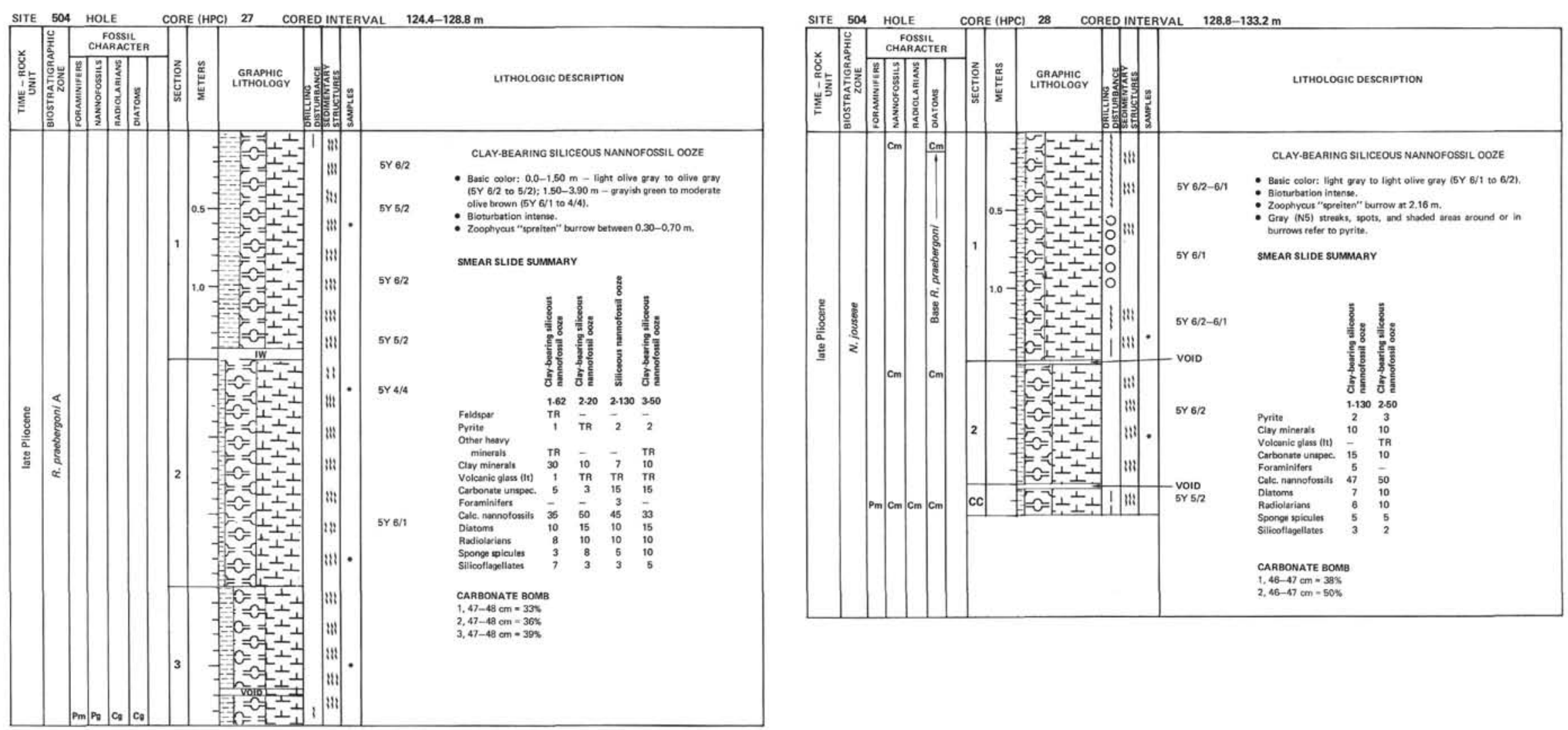

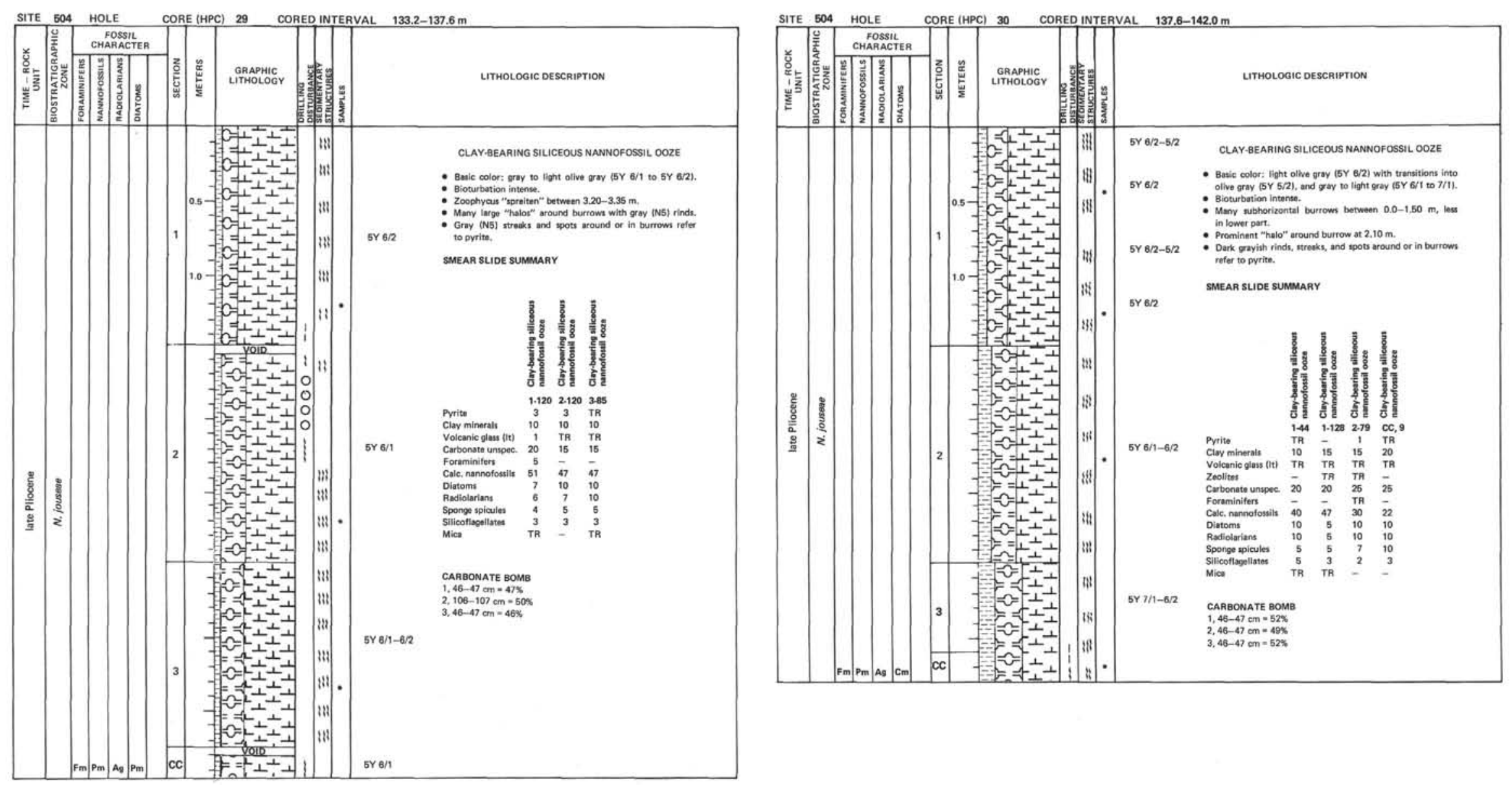

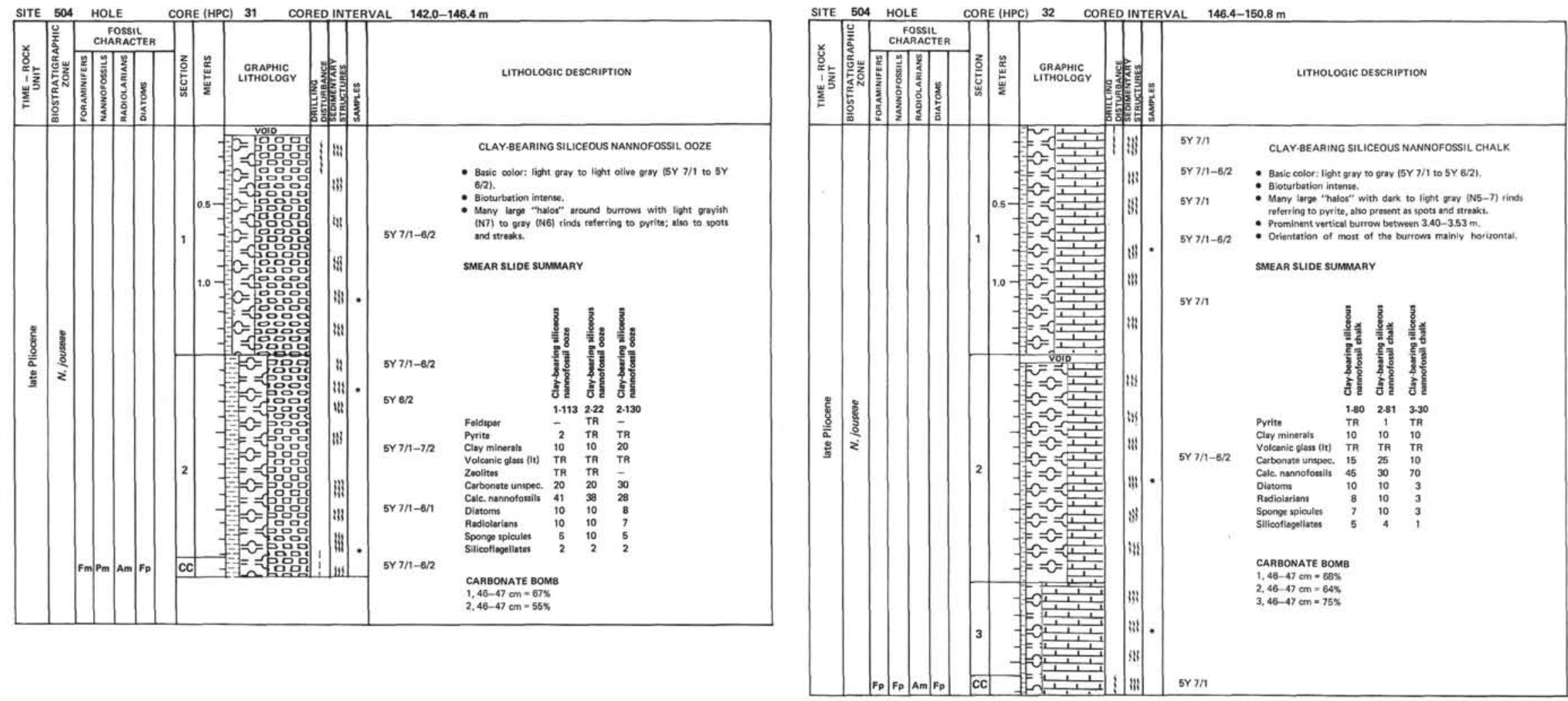

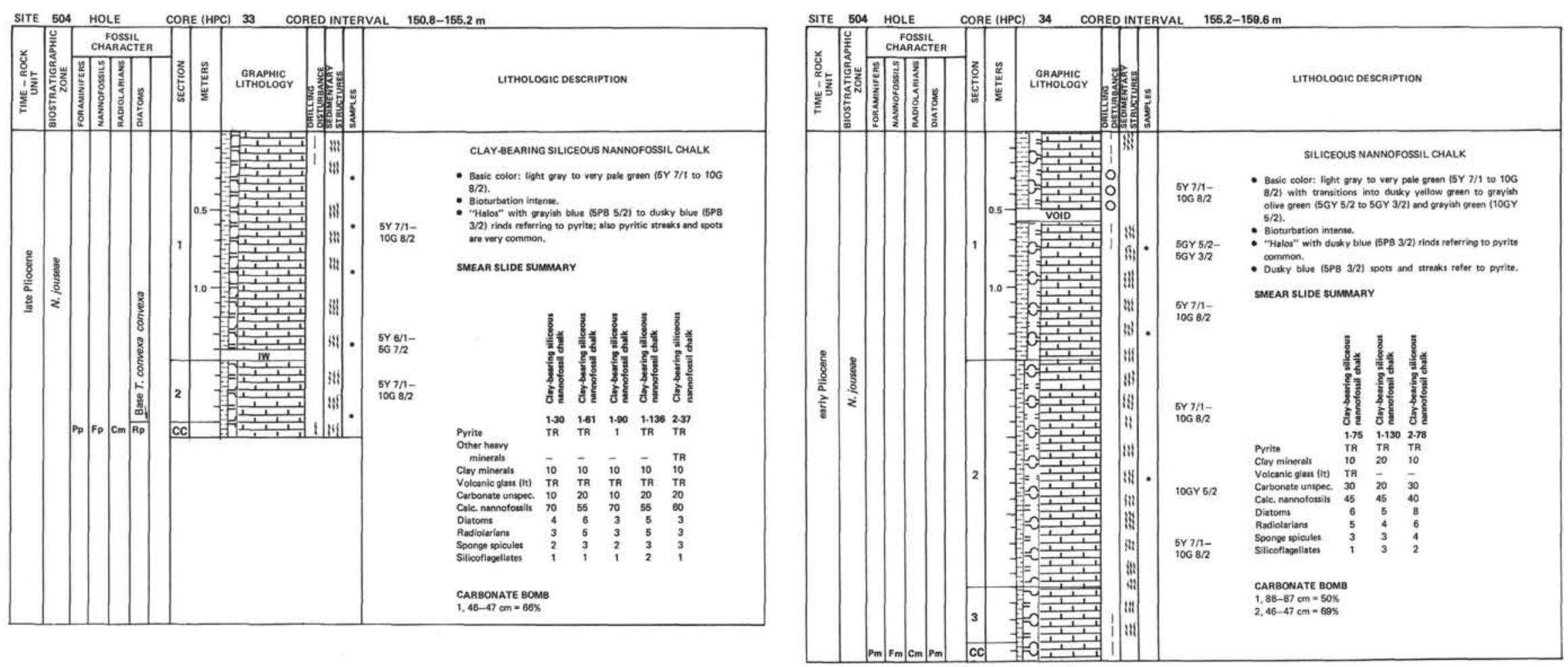

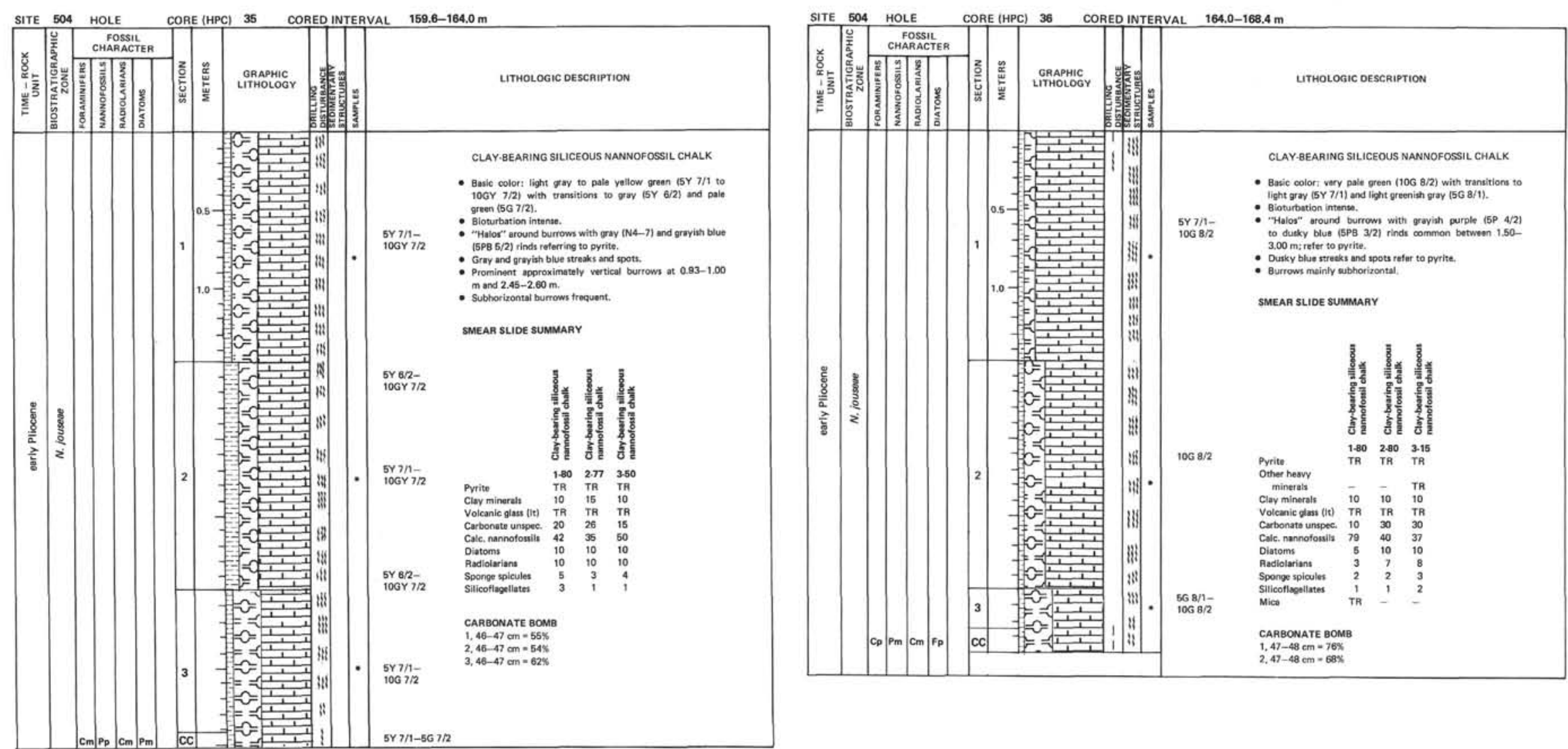

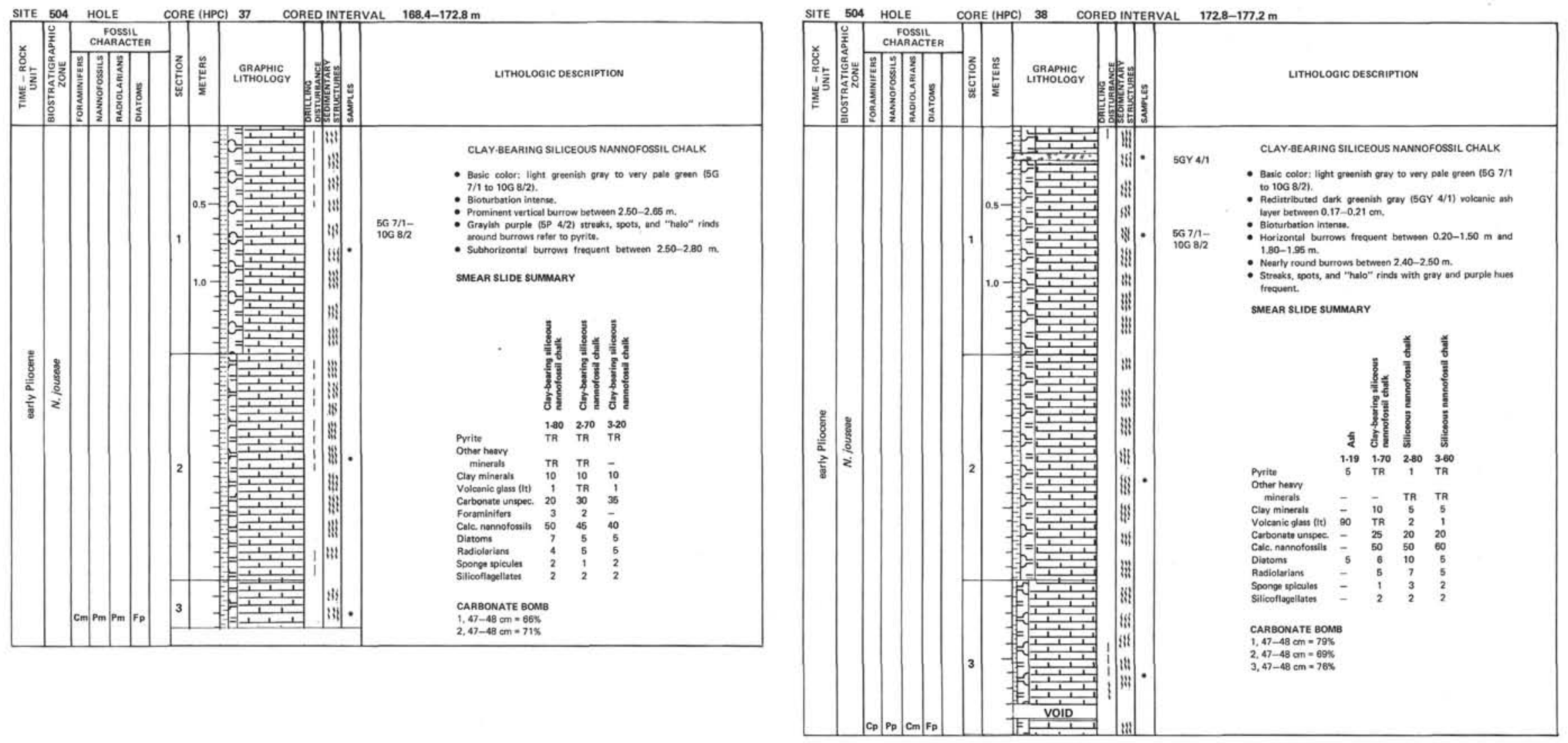

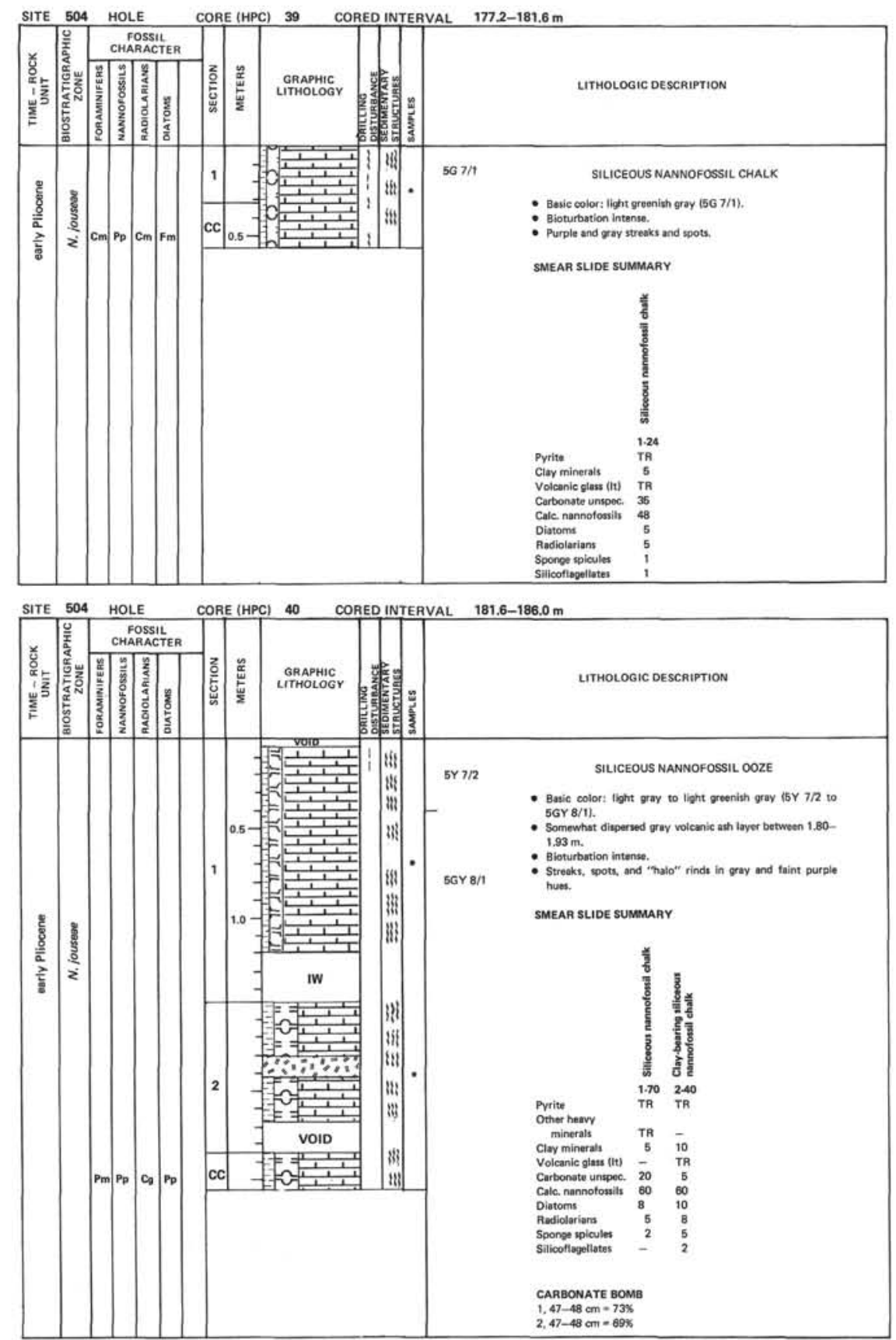

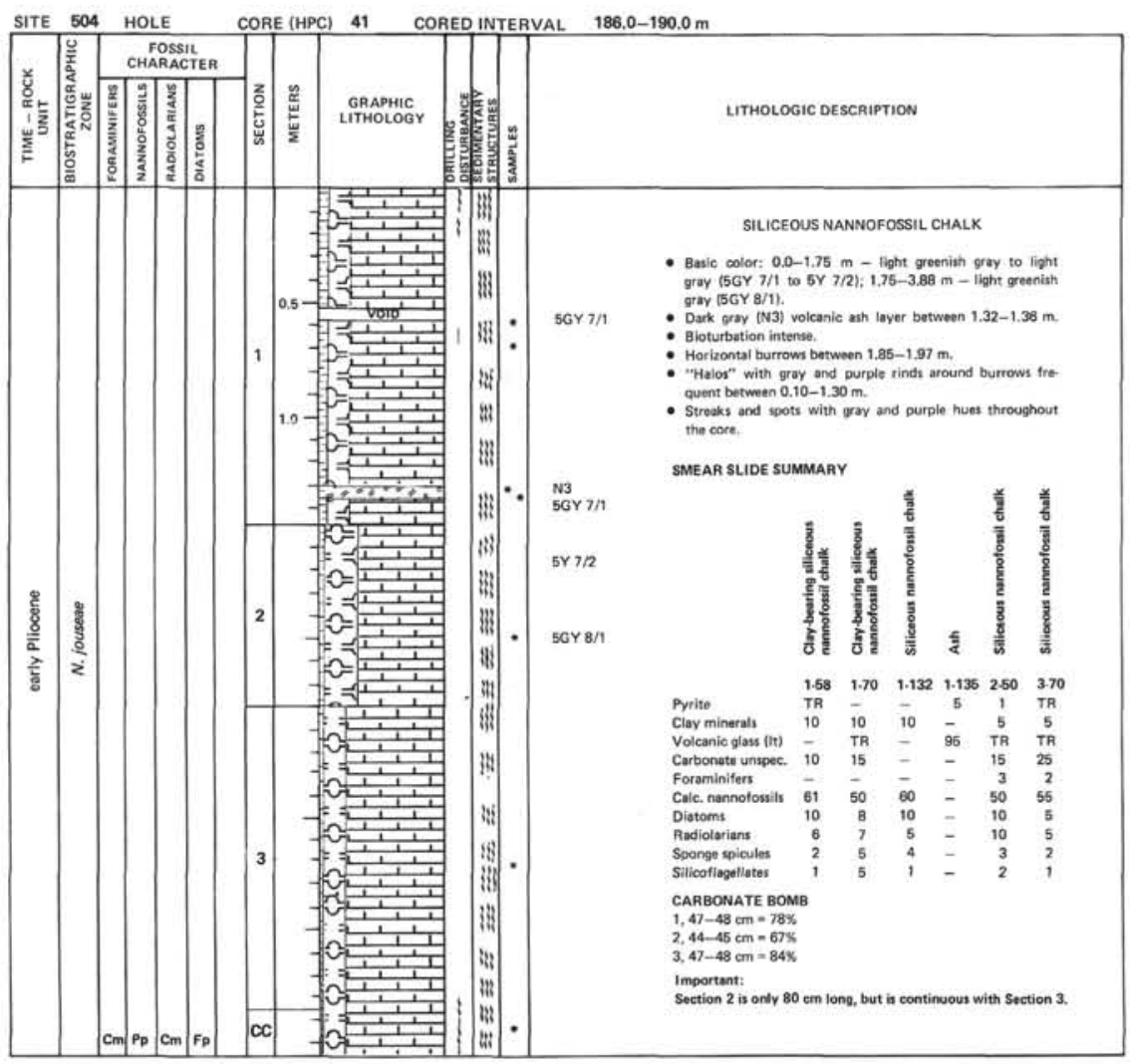



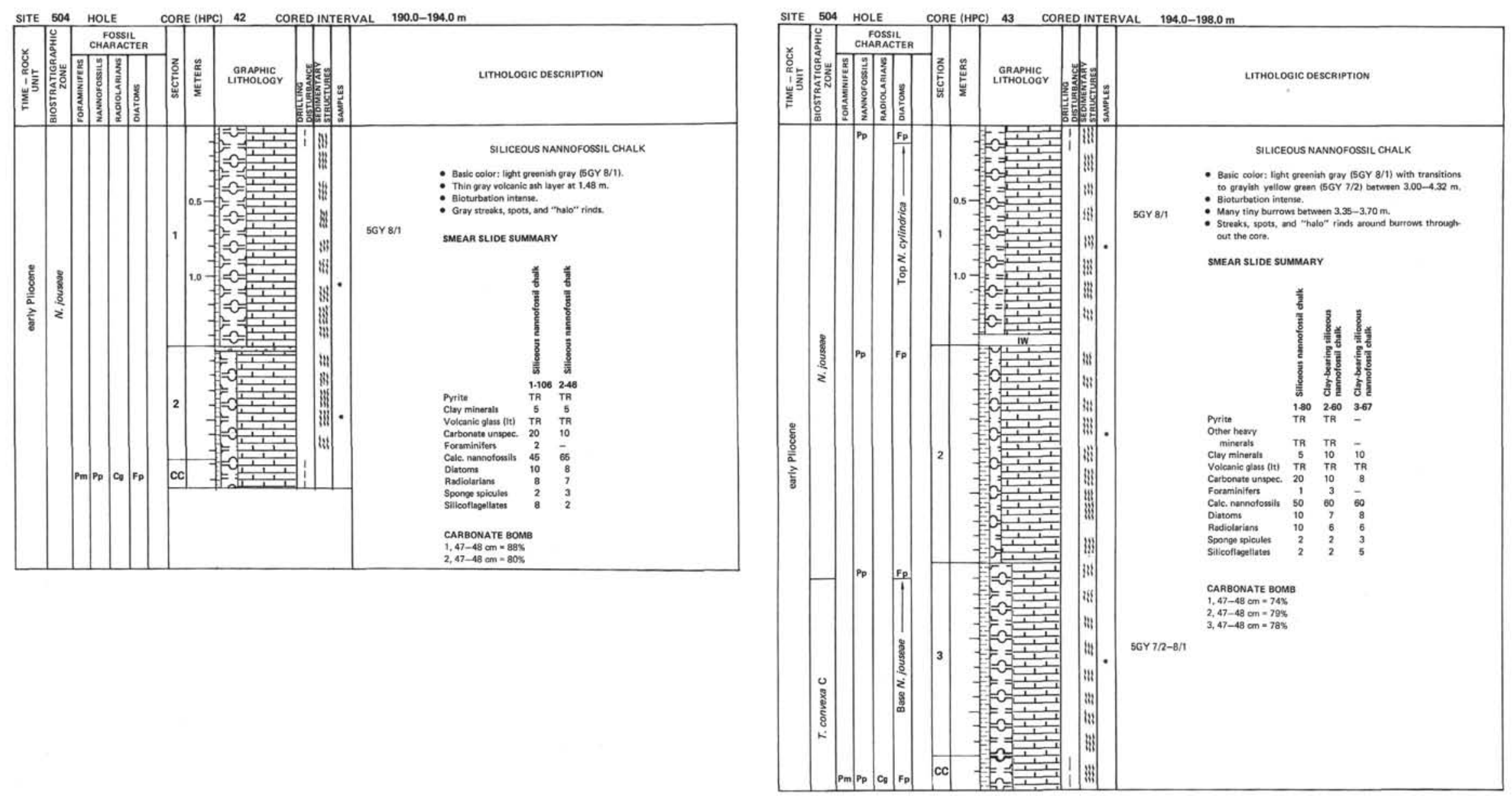
§

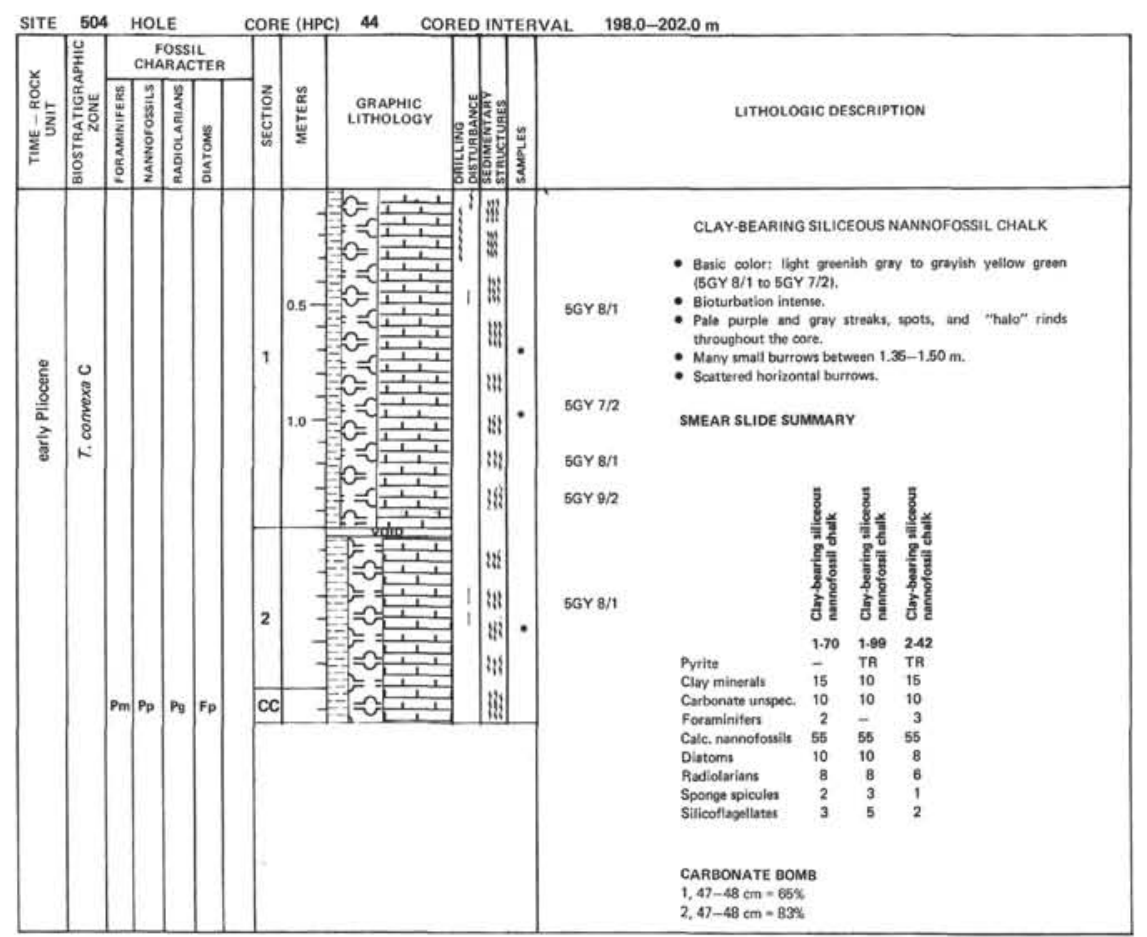

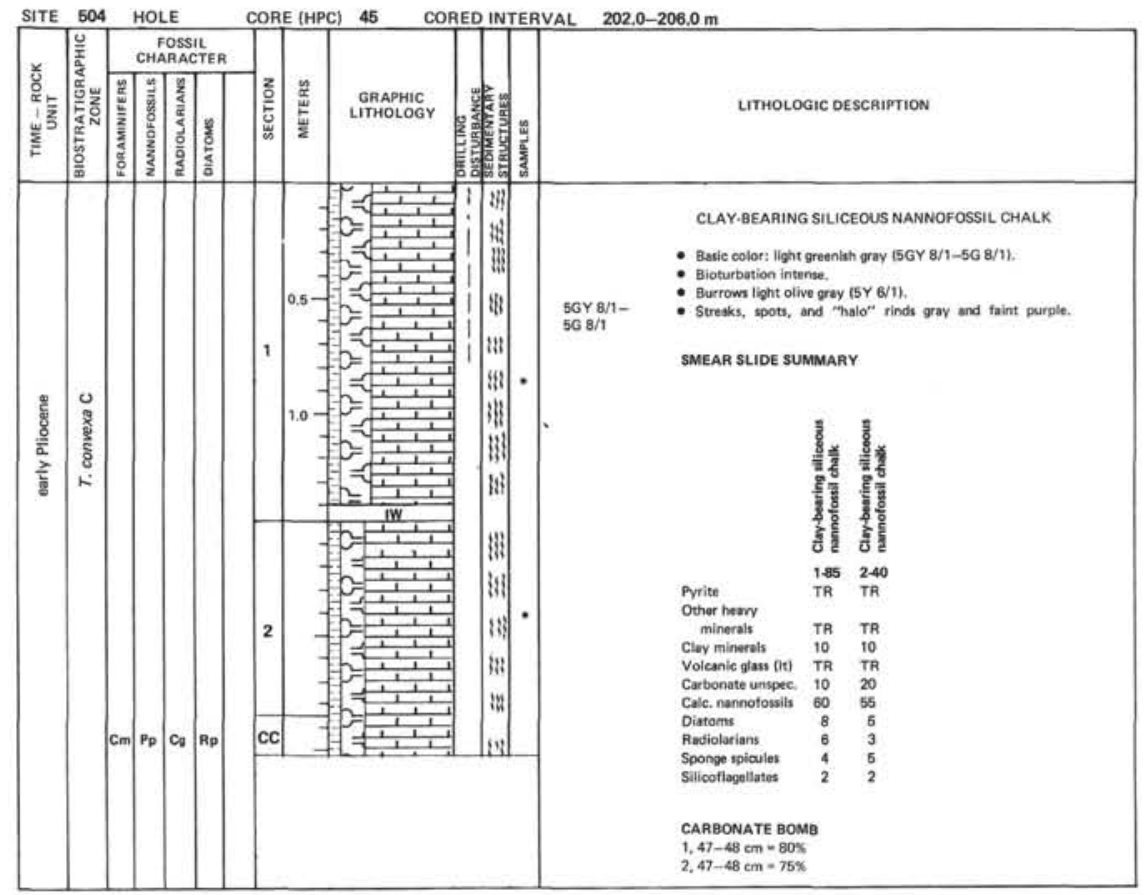



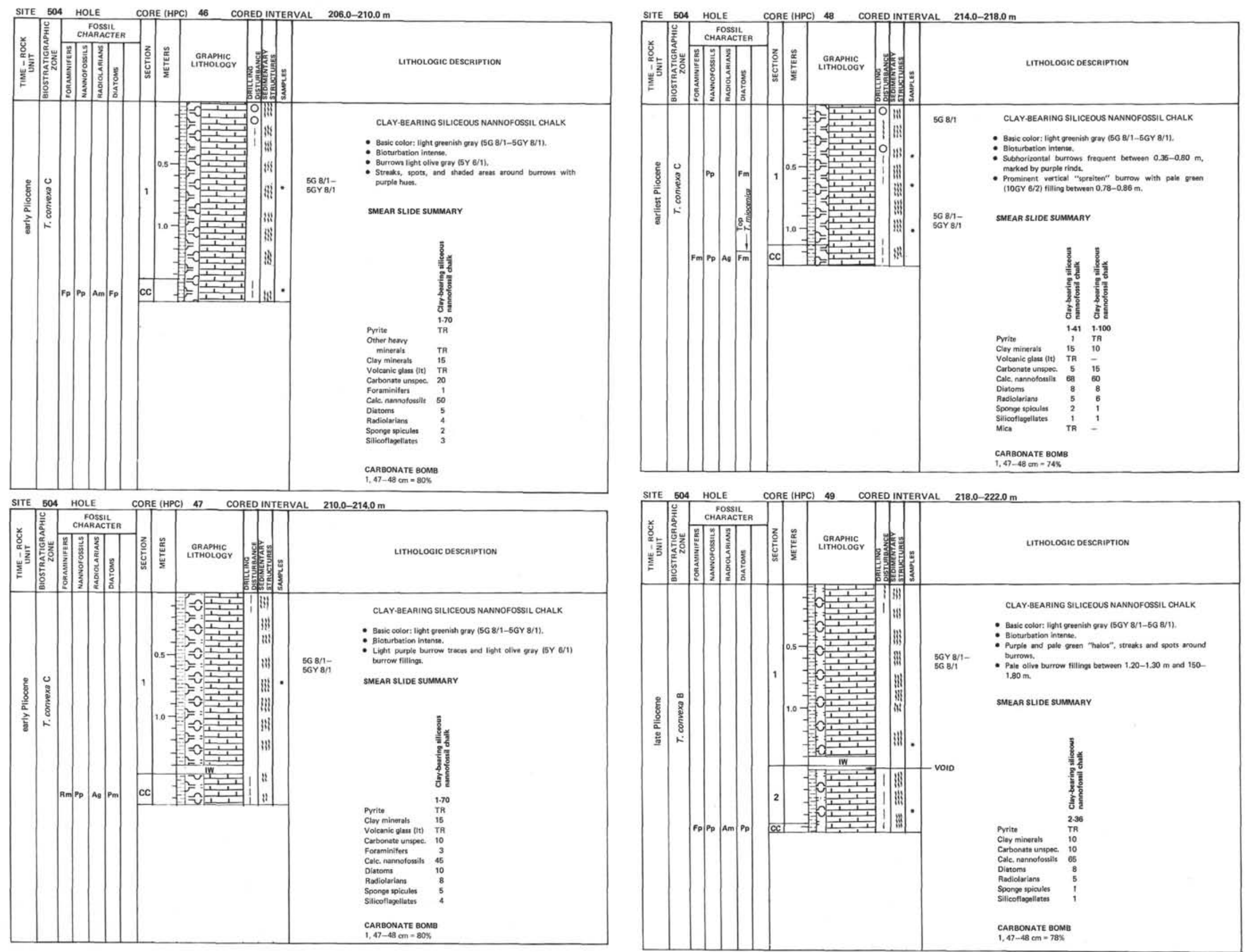

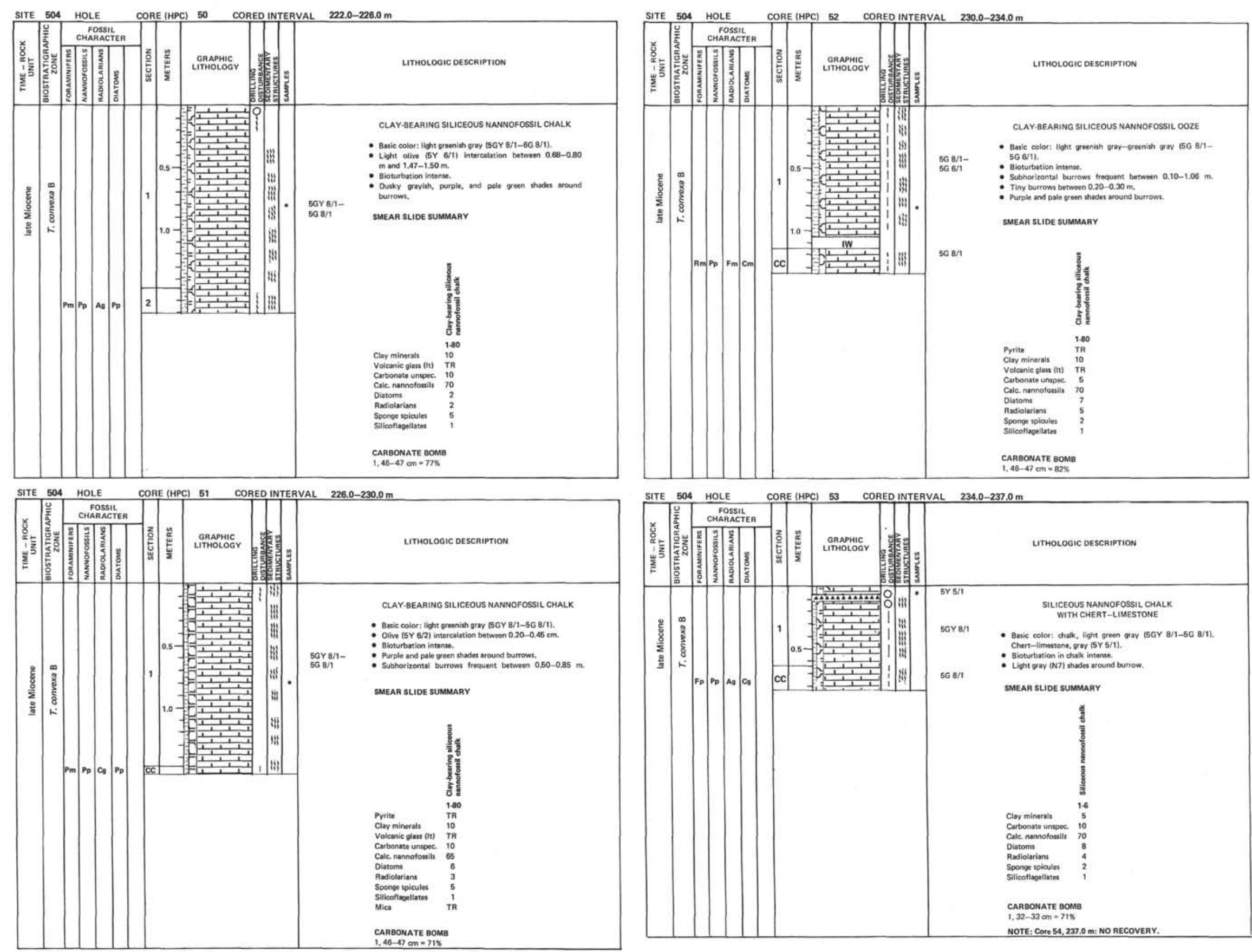

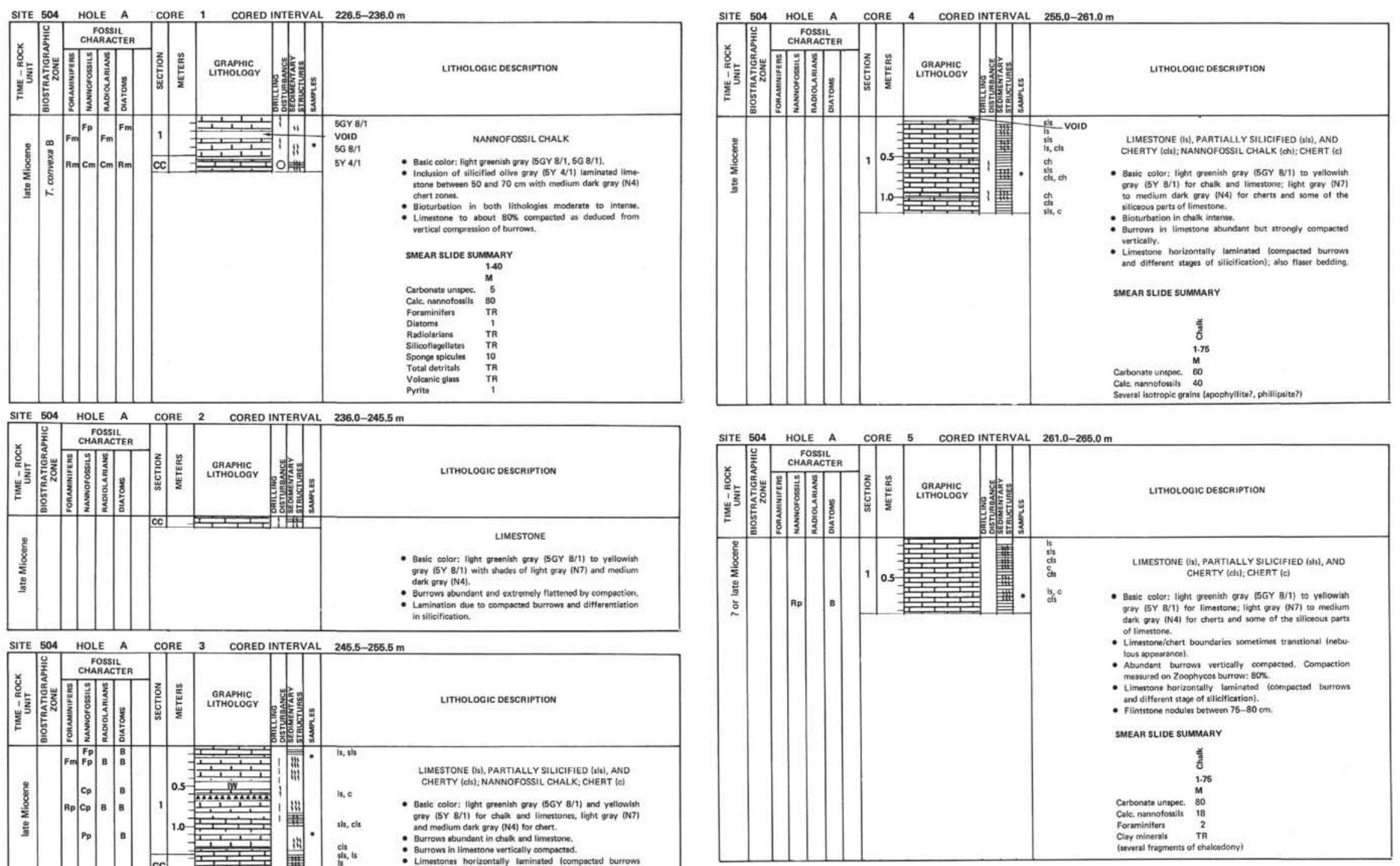

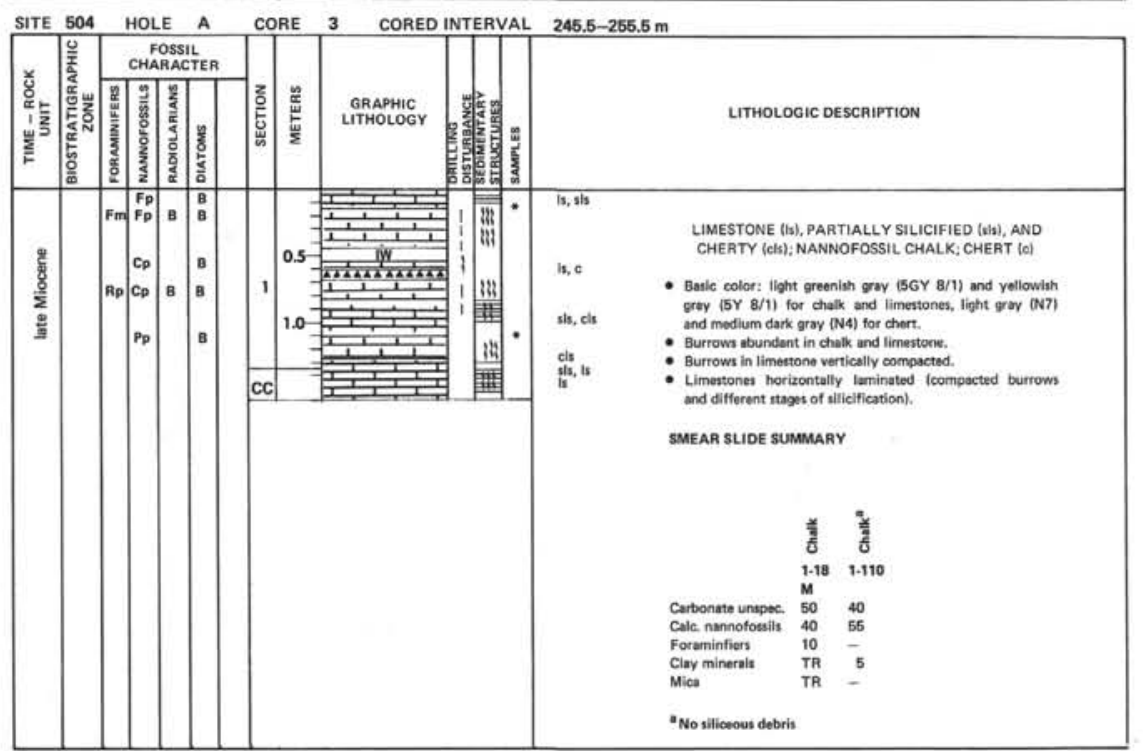




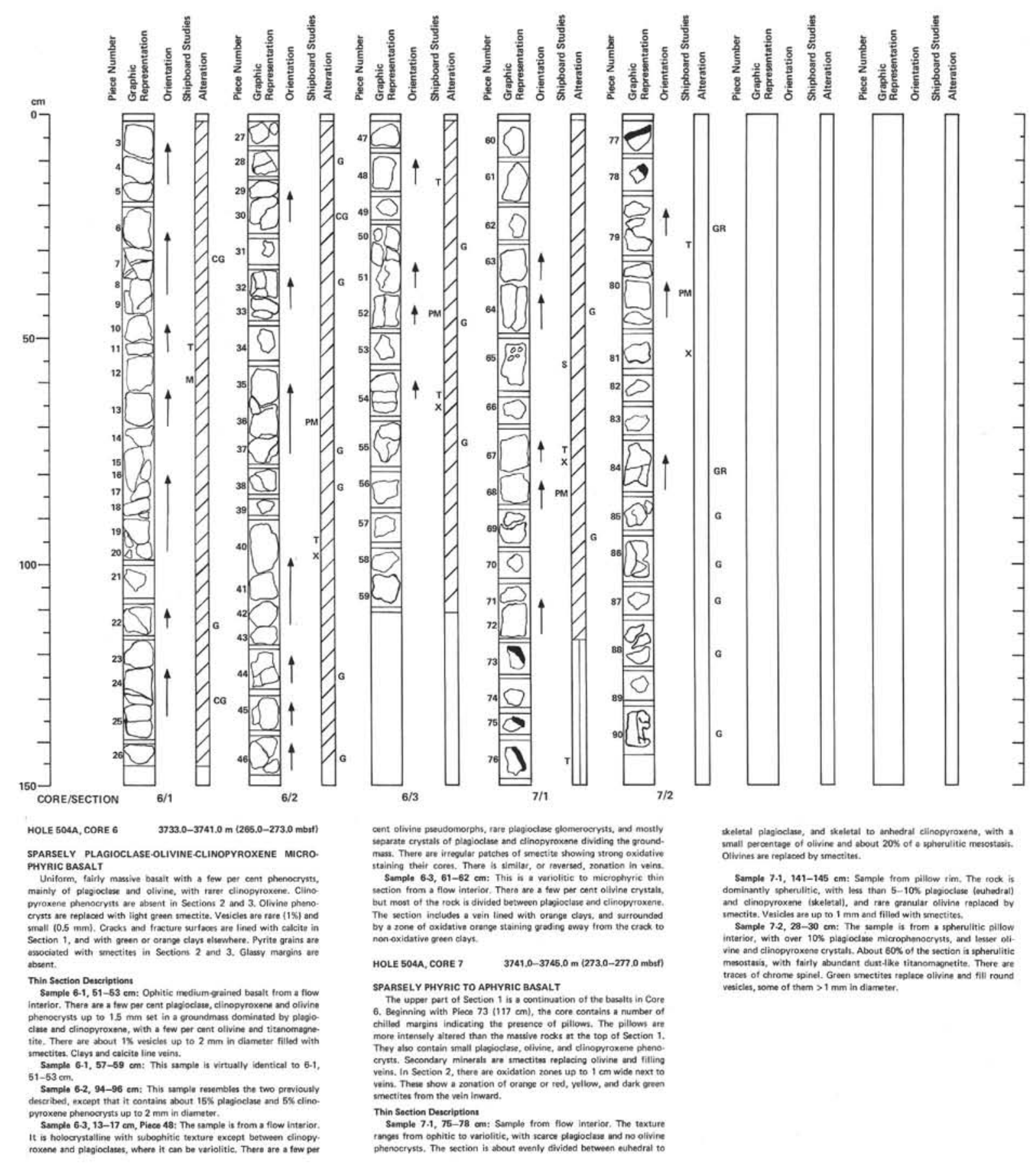

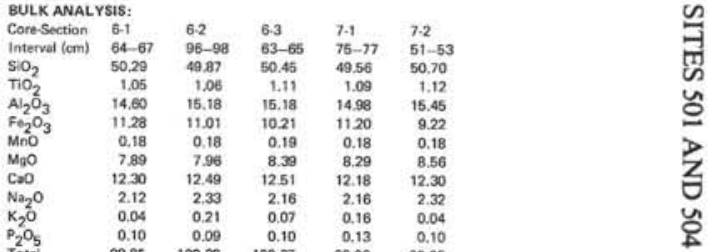




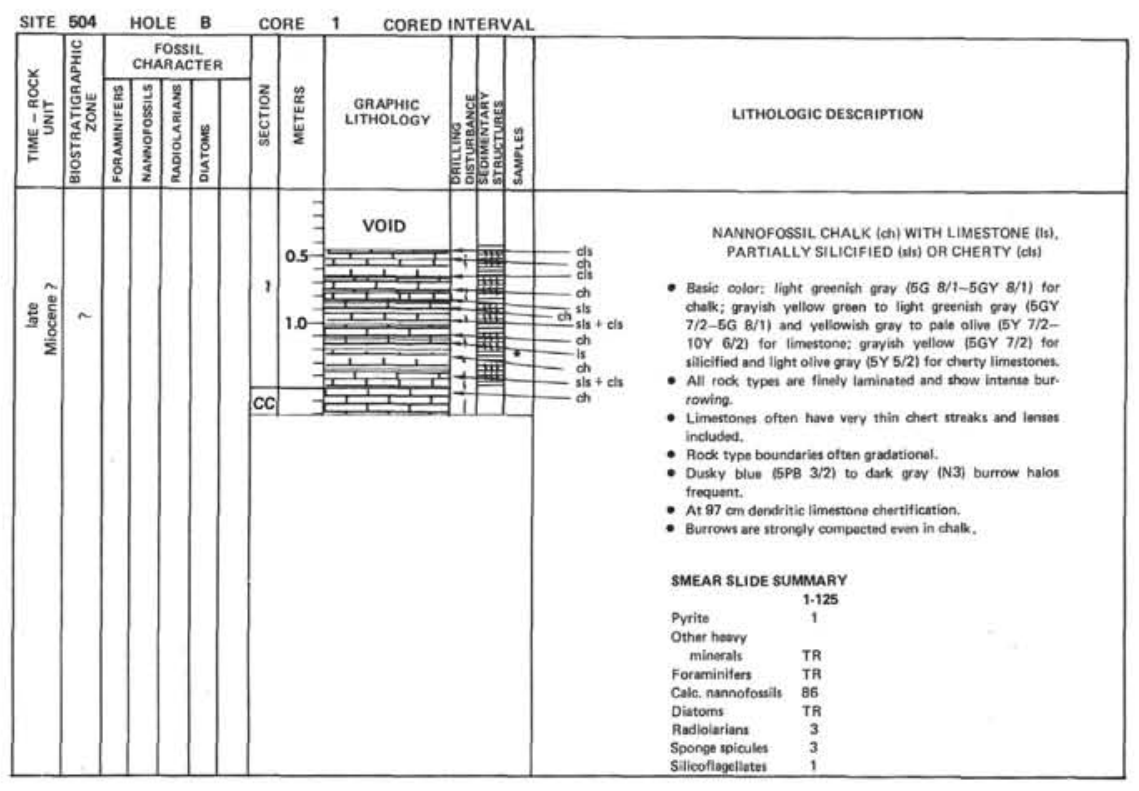

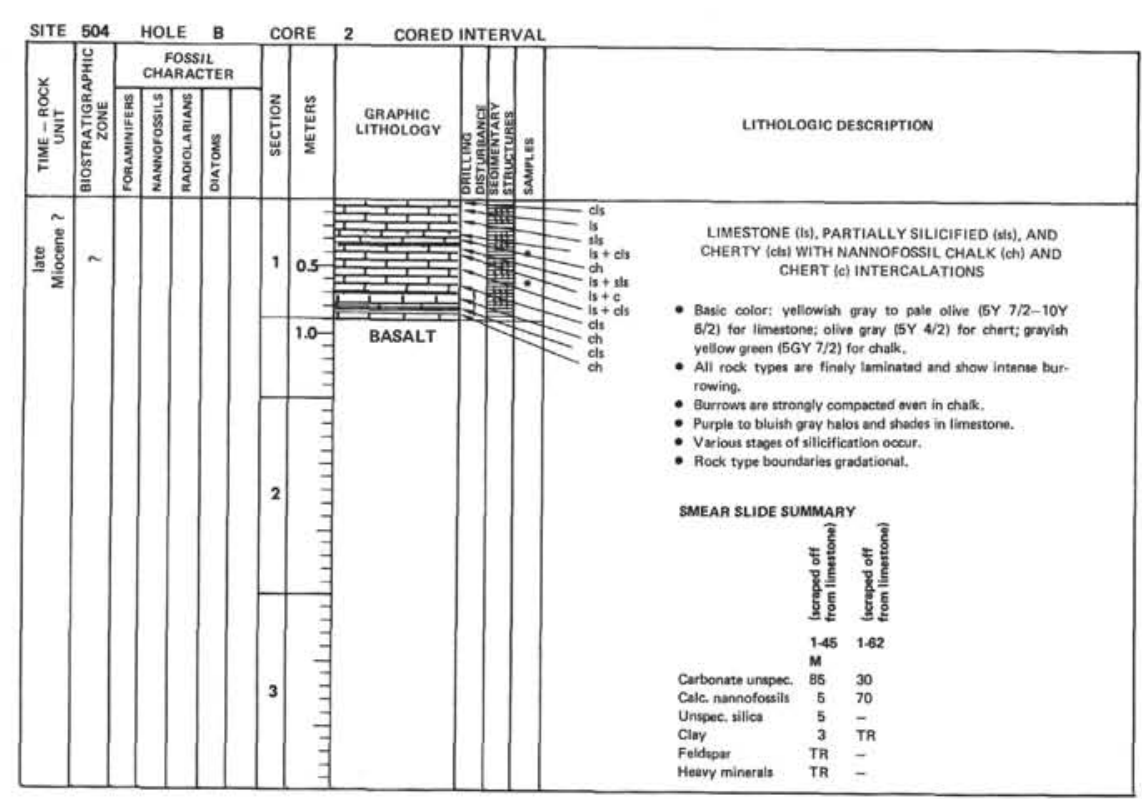




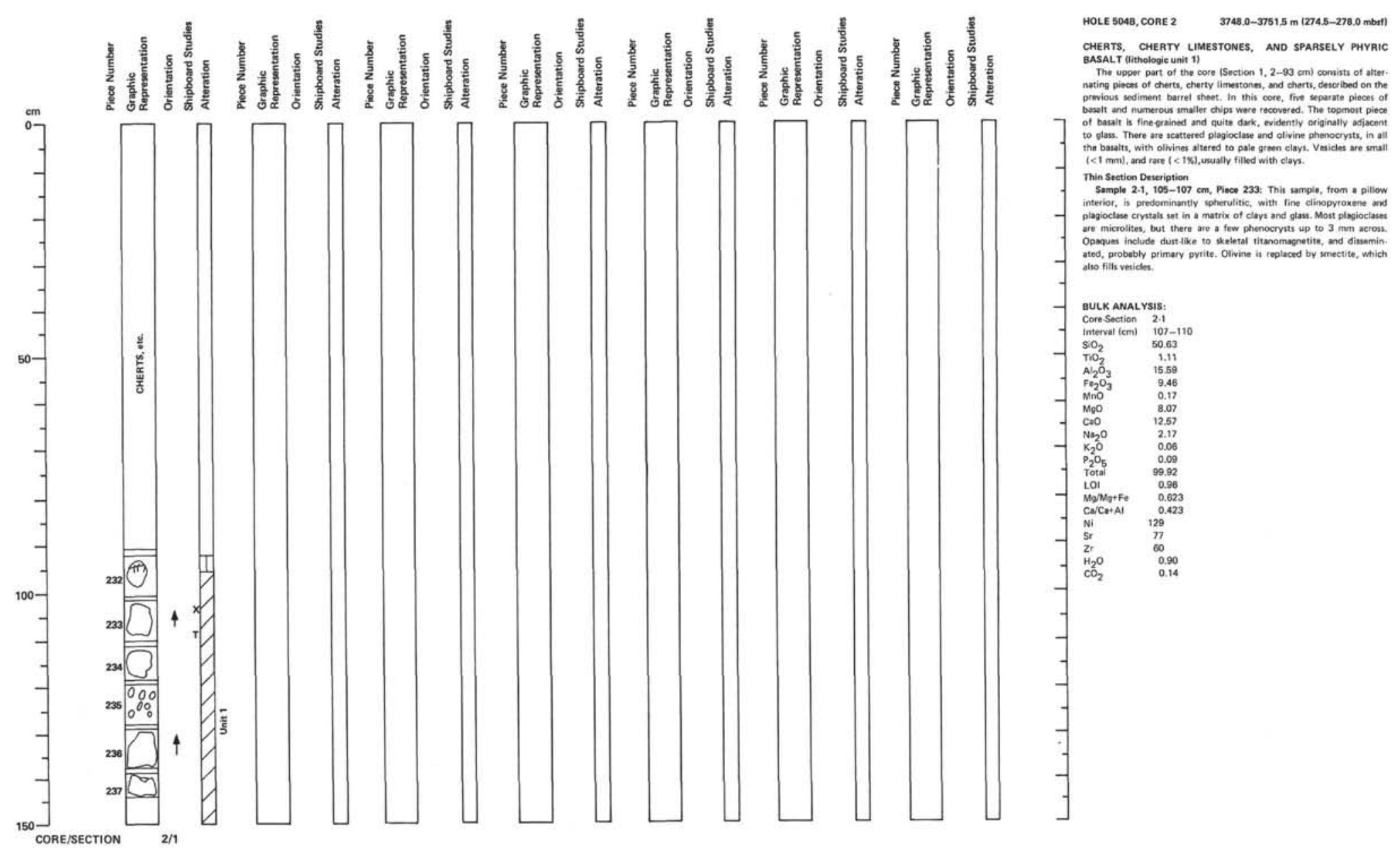




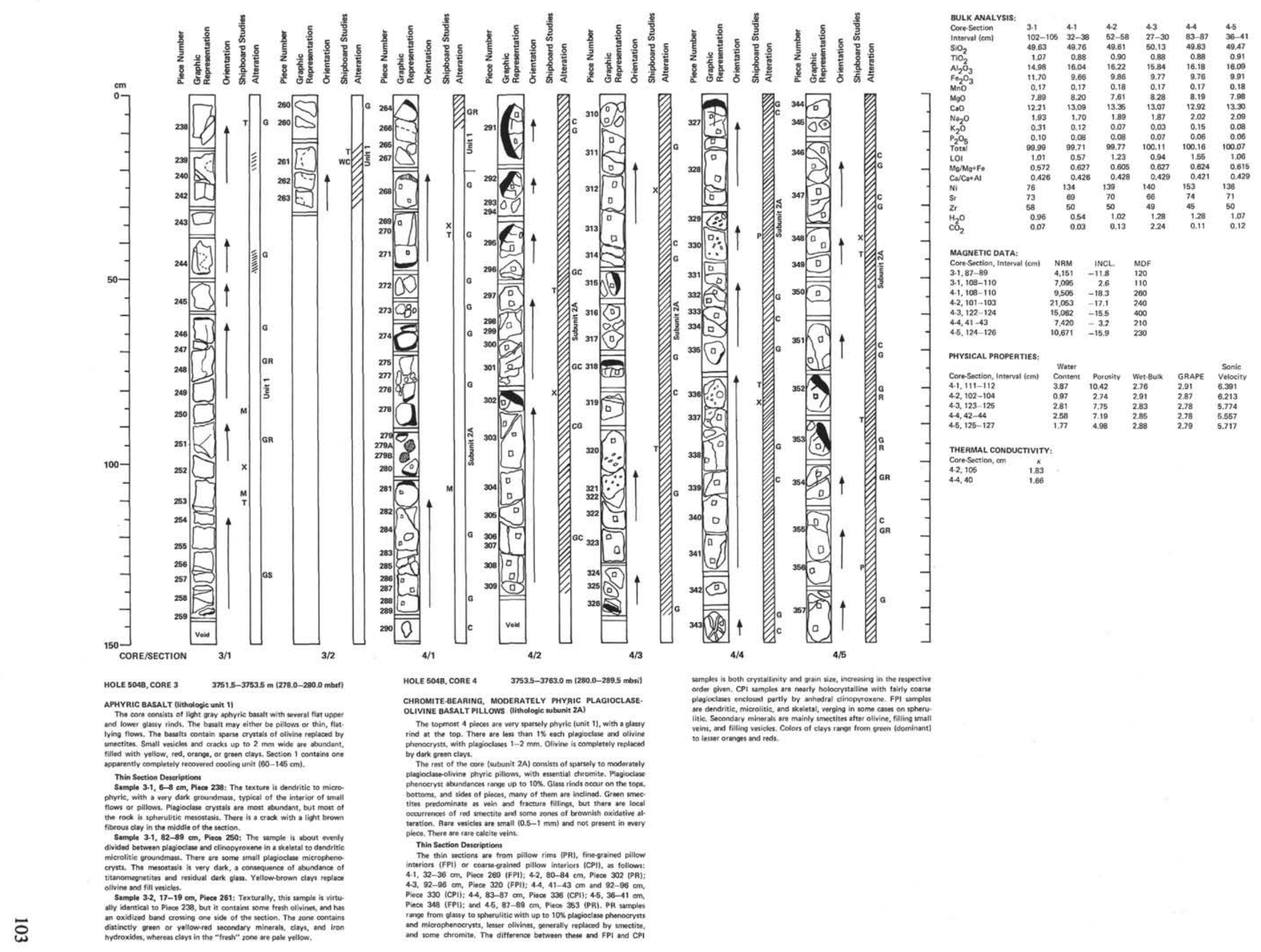




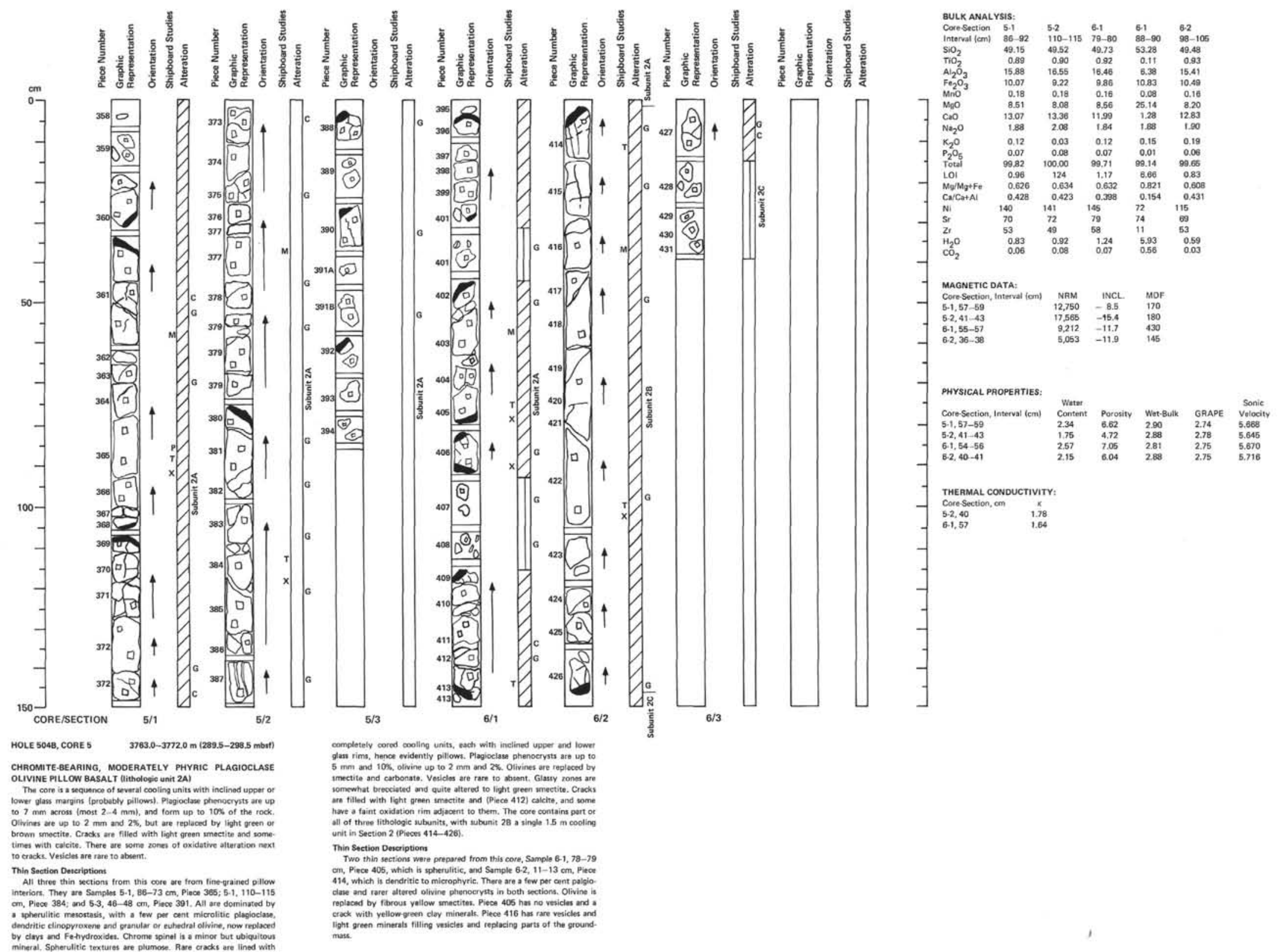




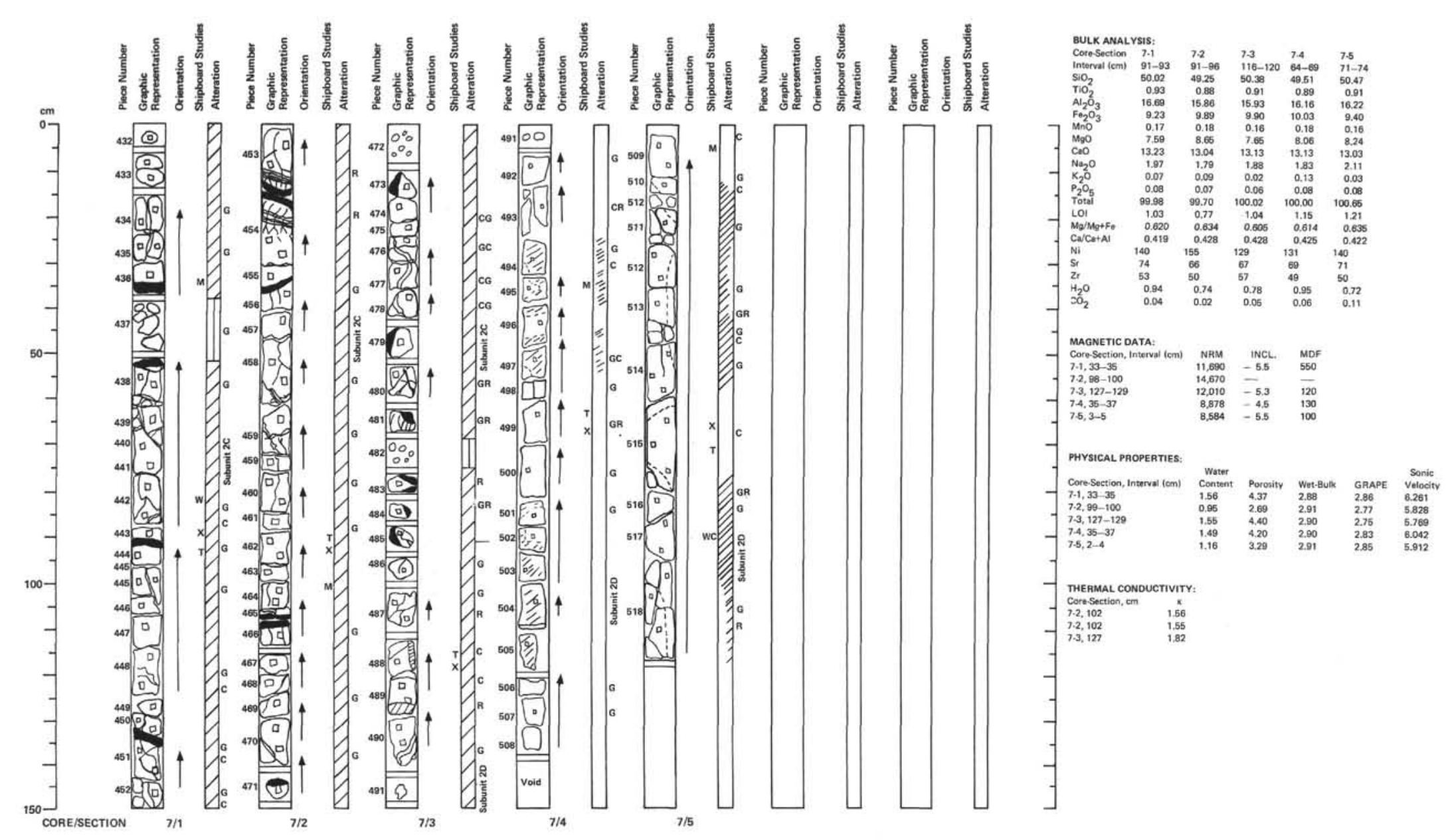

HOLE 5048, CORE 7 3781.0-3790.0m $\mathrm{m}$ (3075-316.5 mban

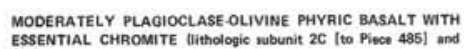
2Di This core comprises the grauser part of lithologic subunit $2 \mathrm{C}$, which Thin Section Descriptions
Five thing sections were prepared from this core, one from a pill

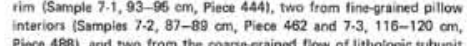

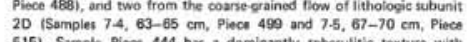

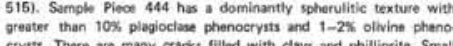

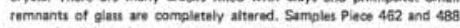

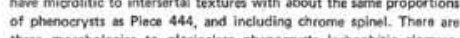

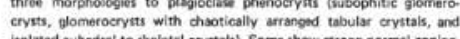

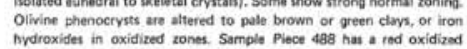

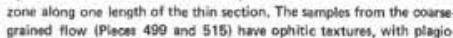

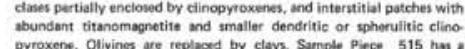

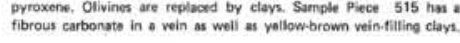




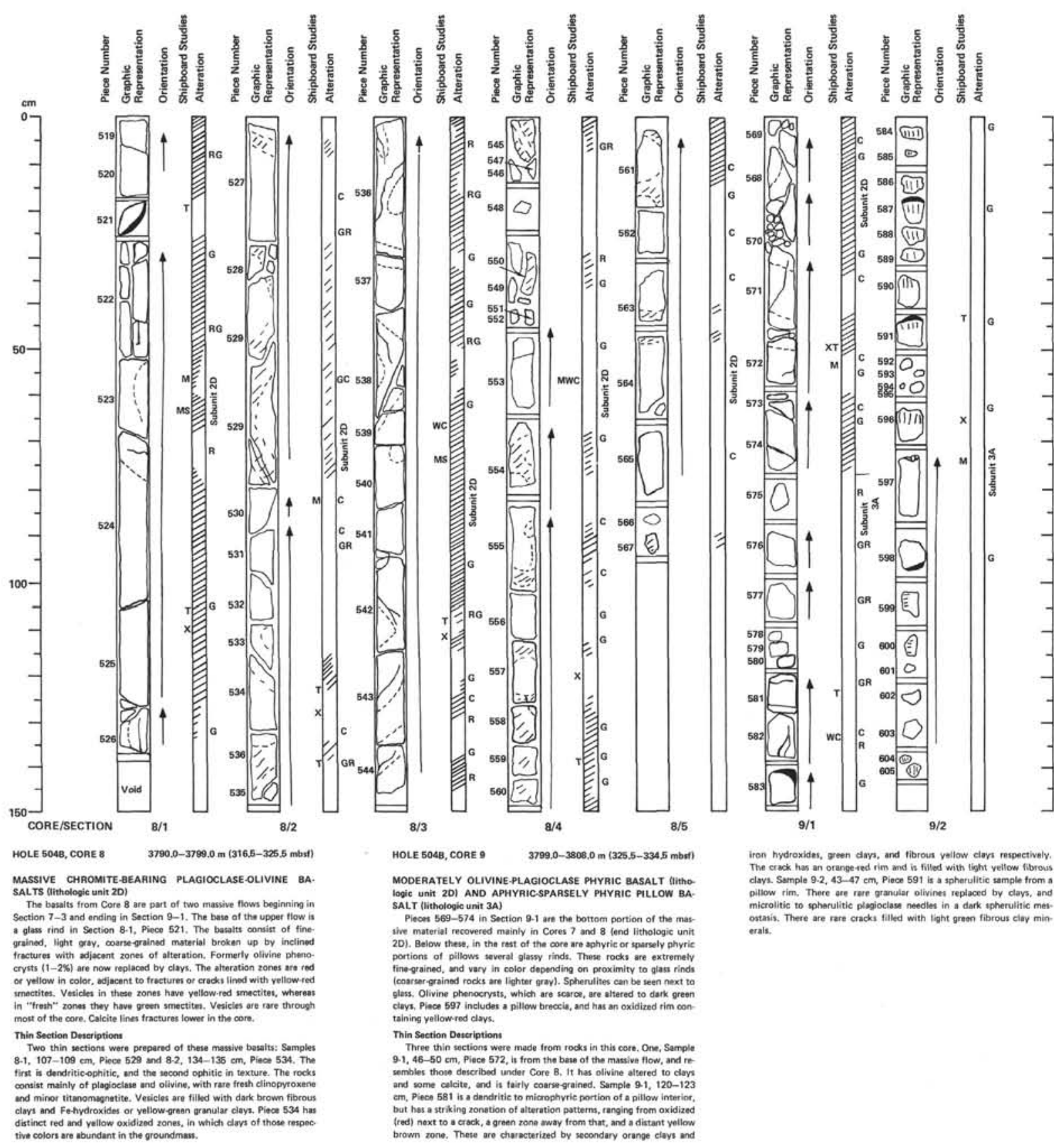




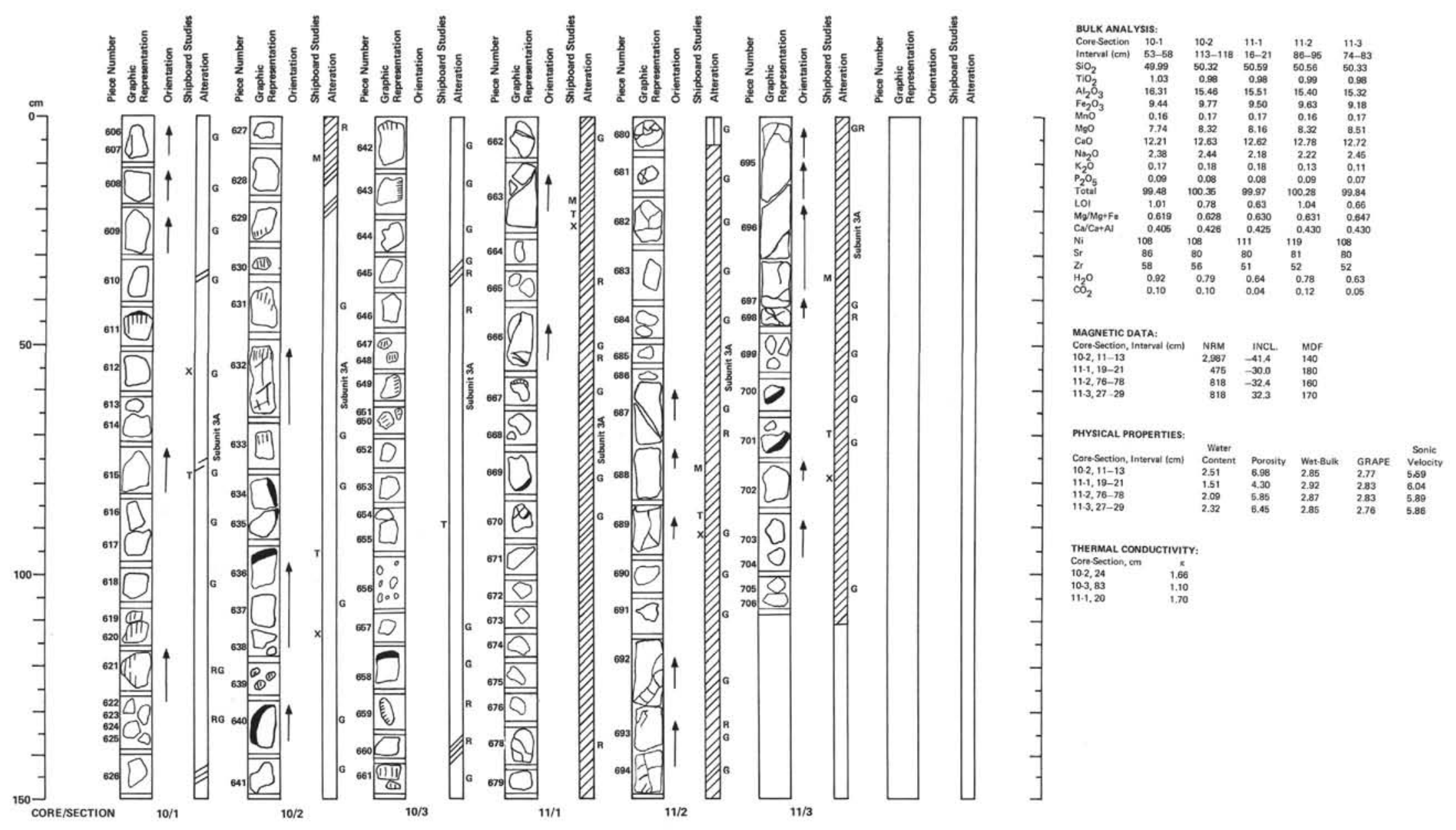

HOLE 5048, CORE $11 \quad 3817.0-3826.0 \mathrm{~m}$ (343.5-352.5 mbart

HOLE 5049 . APHYRIC TO SPAASELY PLAGIOCLASE-OLIVINE PHYRIC

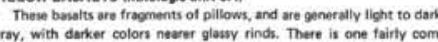

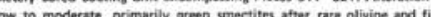

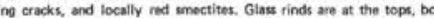

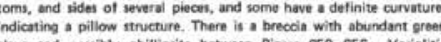

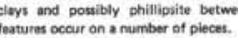

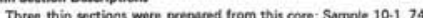
$83 \mathrm{~cm}$, Piece B15, a breccia: Sanple 10-2, $95-100 \mathrm{~cm}$, Piece 636;

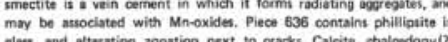

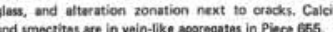

SPAASELY PLAGIOCLASEOLLVINE PHYAIC PILLOW BASALT

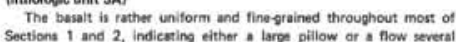

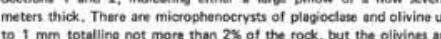

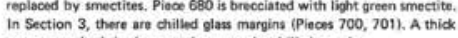

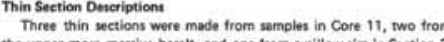

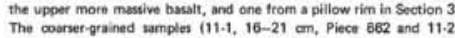

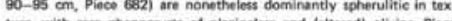
620 has an oxidized zone

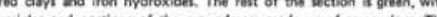

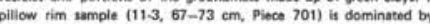

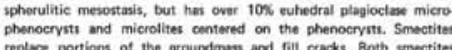




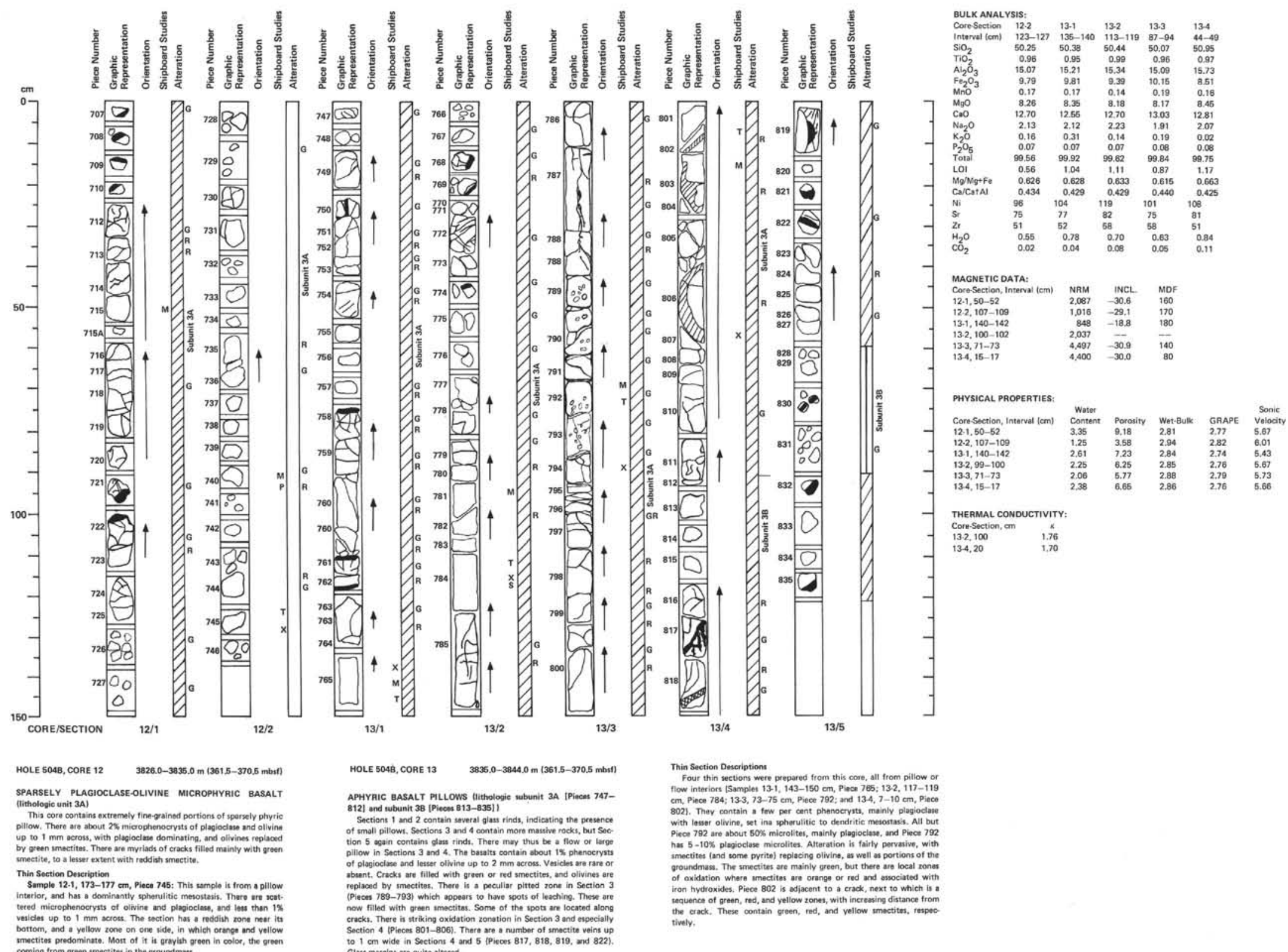




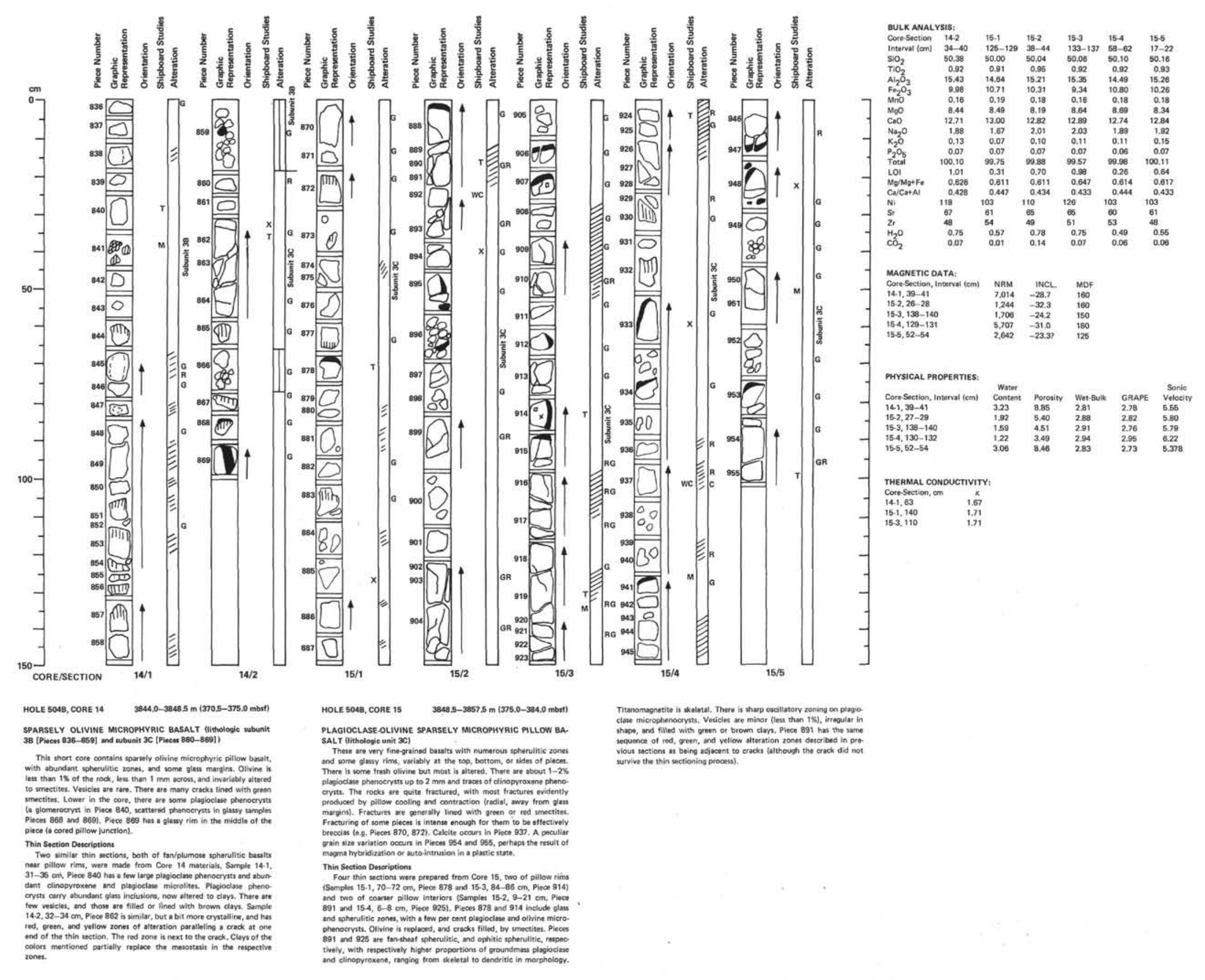




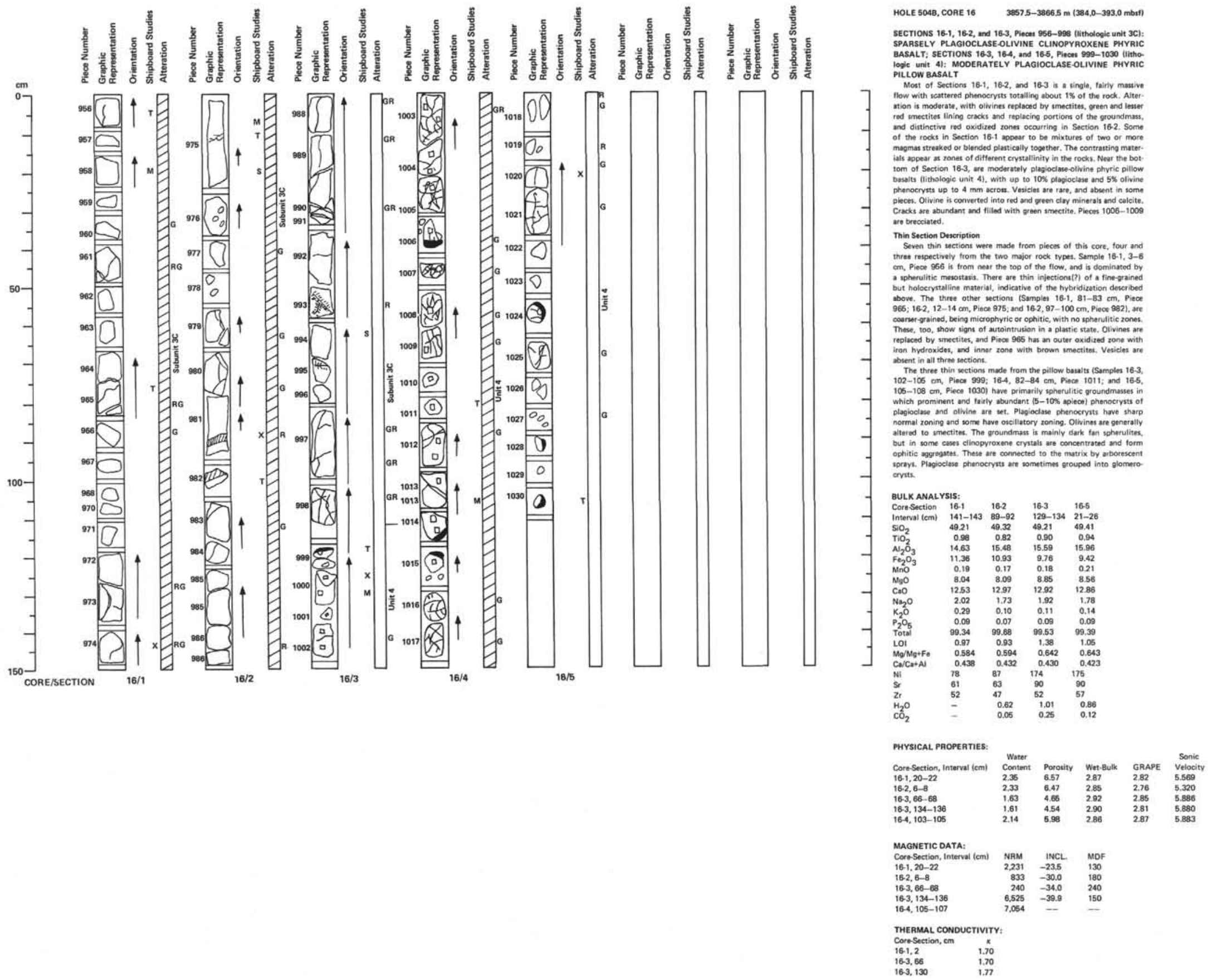




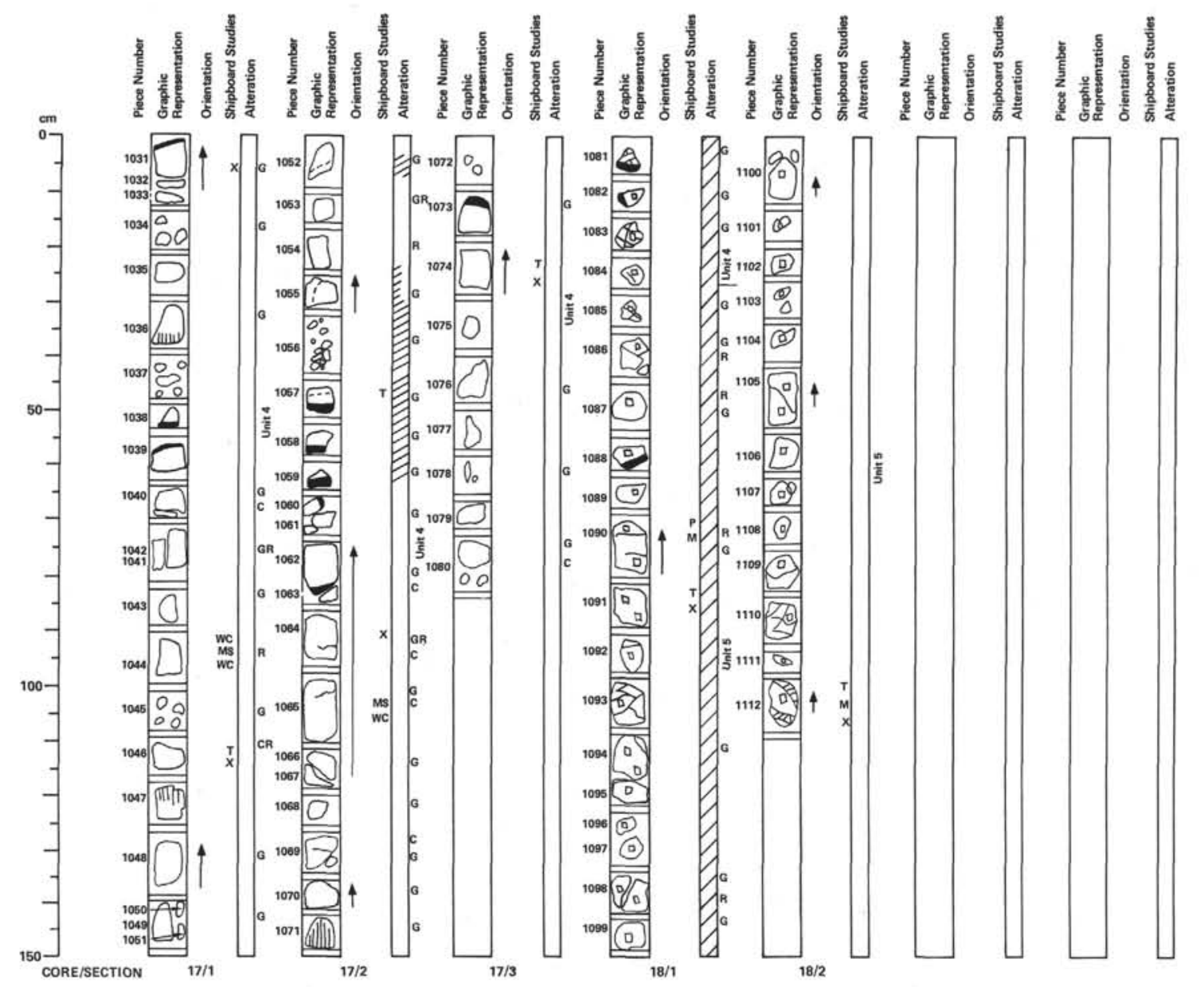

HOLE 5048, CORE $17 \quad 3968.5-3991.5 \mathrm{~m}$ (3933.0-398. 0 mbst) SPAASELY TO MOEERATELY PLAGIOCLASE OLIVINE PHYRIC

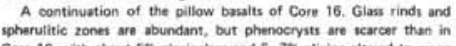

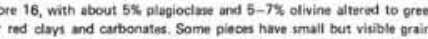

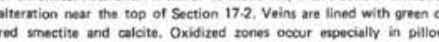

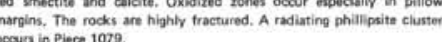

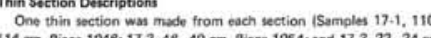

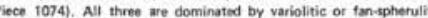

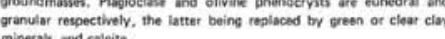

HOLE 5048, CORE 18 3871.0-3876.5 m $3998.0-403.0 \mathrm{mbm}$

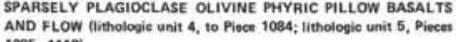

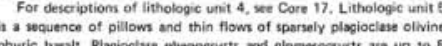

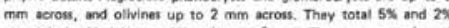

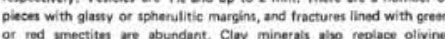
Thin Section Descriptions

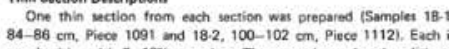

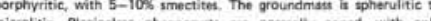

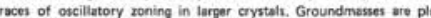

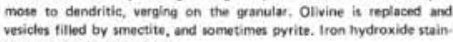
in both nection:

BULK ANALYSIS:

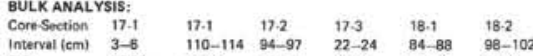

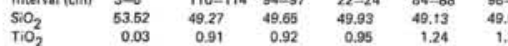

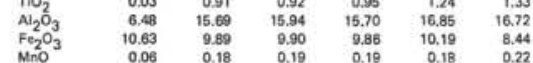
$\mathrm{MgO}$ $\mathrm{CaO}^{\mathrm{Na}} \mathrm{O}_{2}$ $\mathrm{Na}_{2} \mathrm{O}$
$\mathrm{K}_{2} \mathrm{O}$
$\mathrm{P}_{2} \mathrm{O}_{5}$
Totait

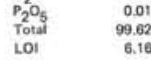

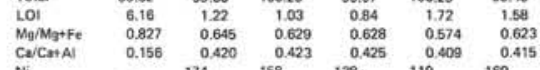
sit

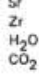

MAONETIC DATA

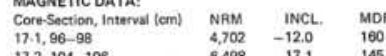

$17 \cdot 2,104-100$
$18-1,171-73$

HYSICAL PROPERTIISS

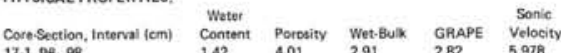
$\begin{array}{llllll}17.1,96-98 & 1.42 & 4.01 & 2.91 & 282 & 5.978 \\ 17.2,104-106 & 2.14 & 6.03 & 2.89 & 280 & 5894 \\ 18.1,71-73 & 4.33 & 11.52 & 2.73 & 2.66 & 5.112\end{array}$ THERMAL CONDUCTIVITY: $\begin{array}{lr}\text { Cort Section, em } & k \\ 17.2,104 & 1.58 \\ 18.1,17 & 1.60\end{array}$ 


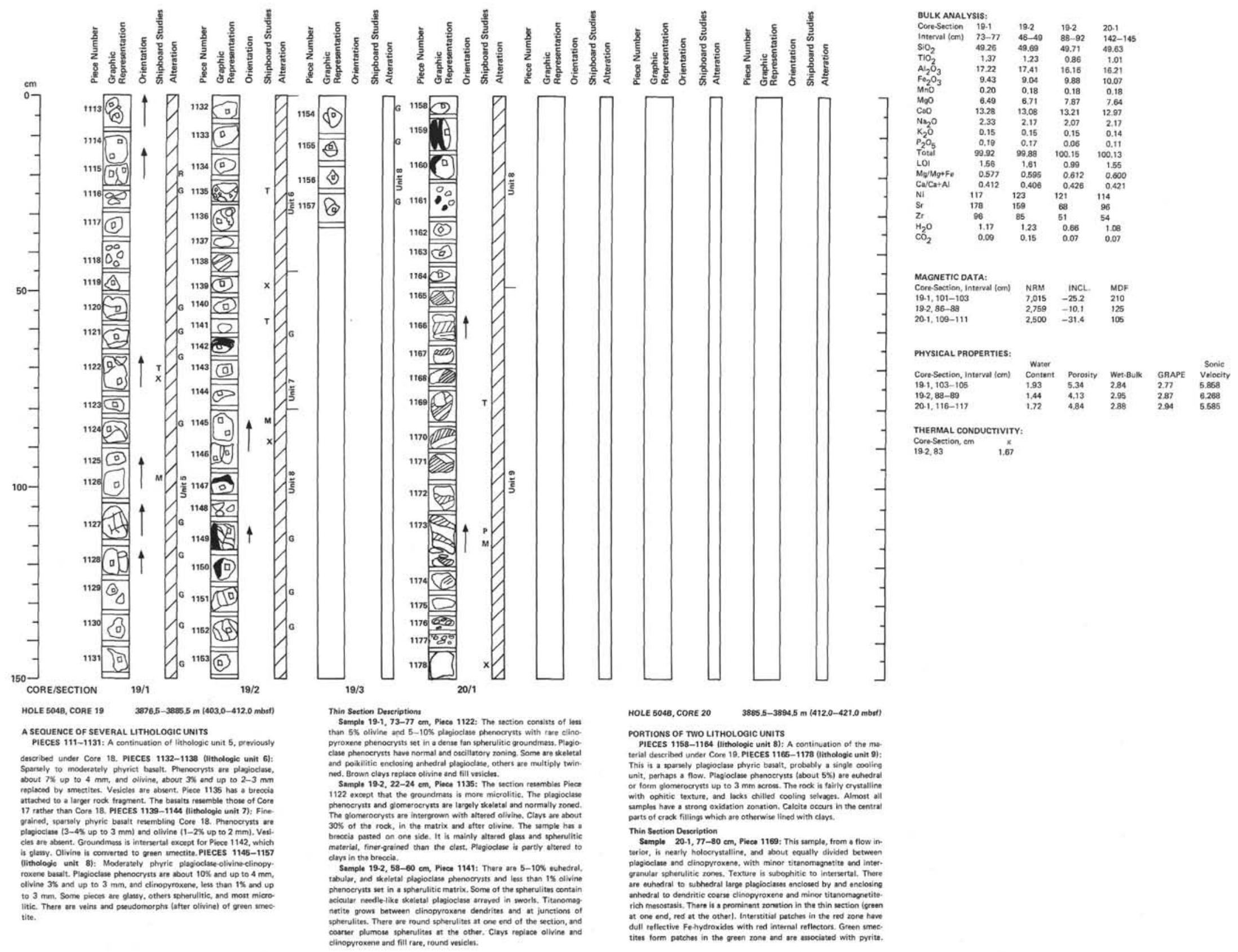




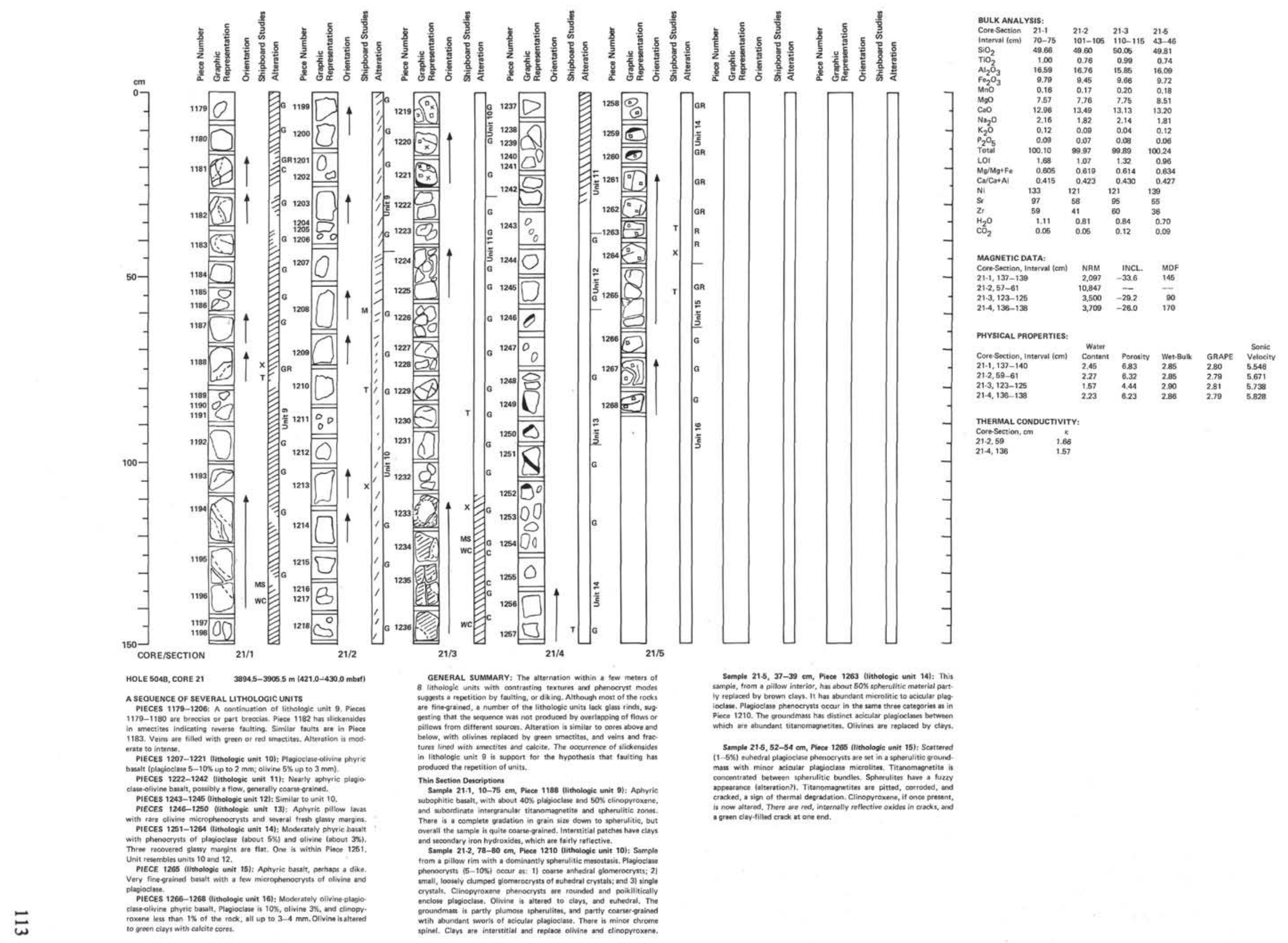




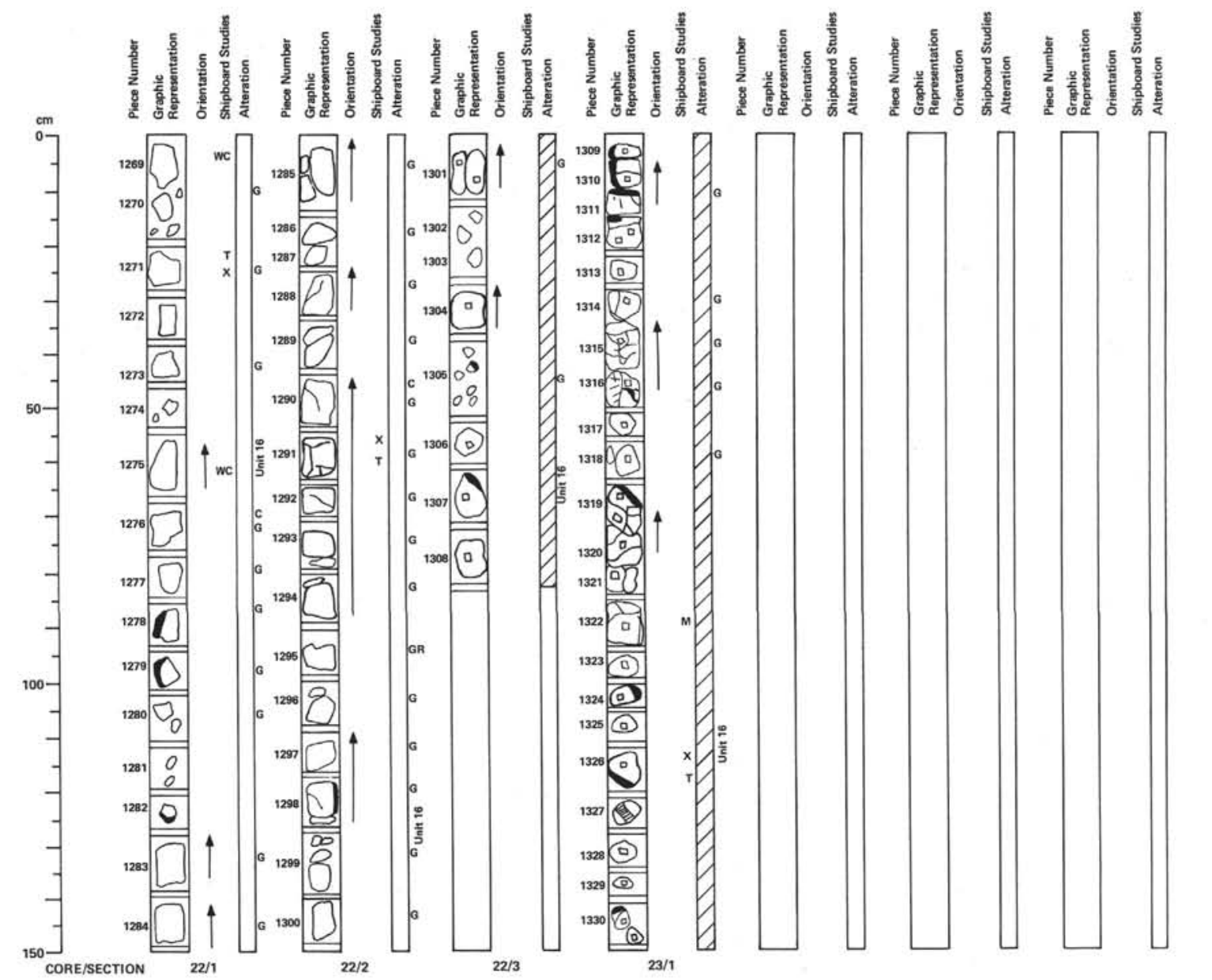

HOLE 5048, CORE 22 3903.5-3912.5 m (430.0-4390 mbert) MODERATELY PLAGIOCLASE-OLIVINE-CUNOPYROXENE PHY

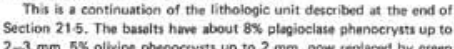

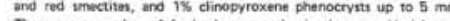

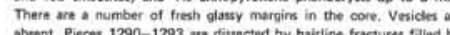

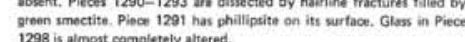

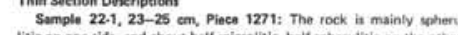

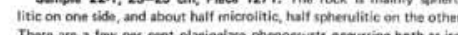

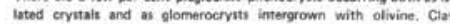

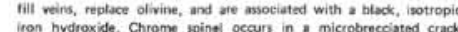

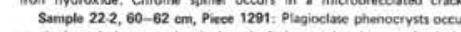

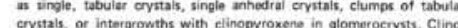

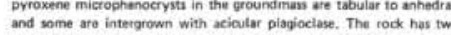

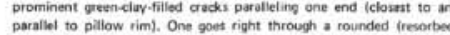
HOLE 50AB, CORE 23 $3912.5-3930.5 \mathrm{~m}(448.0-457.0 \mathrm{mbsi}$ RICPLLOW ROSAATIOCLASE-OLIVINE-CLINOPYROXENE PHY A cam $3 x$ and up to $3 \mathrm{~mm}$, and clinopyroxene $3 \mathrm{~K}$ end up $103 \mathrm{~mm}$. Vesicts

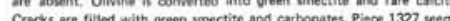
to be an errratic from than rock types of Cores 20 und 21, with the to oxication zones.

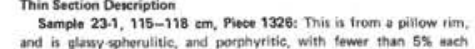
and is glasws spherulitic, and porphyritic, with tewer then 55 mach

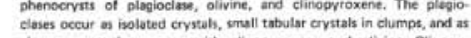

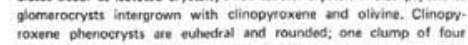

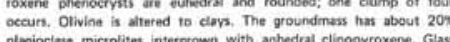

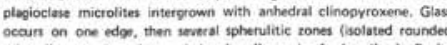
cecun asocisted with yeen clavs in the matrix. A chromian loinel trappers in a plagioclase phenocryat.

BULK ANALYSIS:

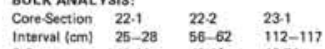
$\mathrm{FiO}_{2}$
$\mathrm{Nl}_{2} \mathrm{O}$
$\mathrm{Fe}_{2} \mathrm{O}$
$\mathrm{MnO}$
$\mathrm{MnO}$
$\mathrm{MaO}$
$\mathrm{CaO}$
$\mathrm{Na}_{2} \mathrm{O}$ $\begin{array}{cccc} & 12.88 & 13.42 & 13.15 \\ \mathrm{Na}_{2} \mathrm{O} & 1.67 & 1.77 & 1.95 \\ \mathrm{~K}_{2} \mathrm{O} & 0.09 & 0.07 & 0.14 \\ & 0.09 & 0.14\end{array}$

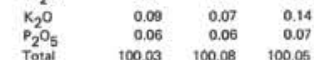

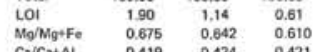
$\begin{array}{lrrr}\text { Caicatal } & 0.419 & 0.424 & 0.421 \\ \text { Nit } & 139 & 131 & 1.42\end{array}$ $\mathrm{Ni}$

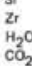
$\mathrm{CO}_{2} \quad 0.12$ $\begin{array}{llcc}\text { Cores Section, Interval (cm) } & \text { NAM } & \text { INCL. } & \text { MDF } \\ 22-1,62-64 & 4,294 & -26.5 & 370 \\ 231,89-90 & 4,855 & -40.0 & 160\end{array}$ HYSICAL PROPERTIES:

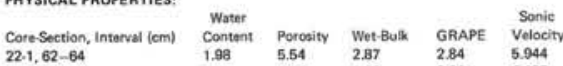
THERMAL CONOUCTIVITY 


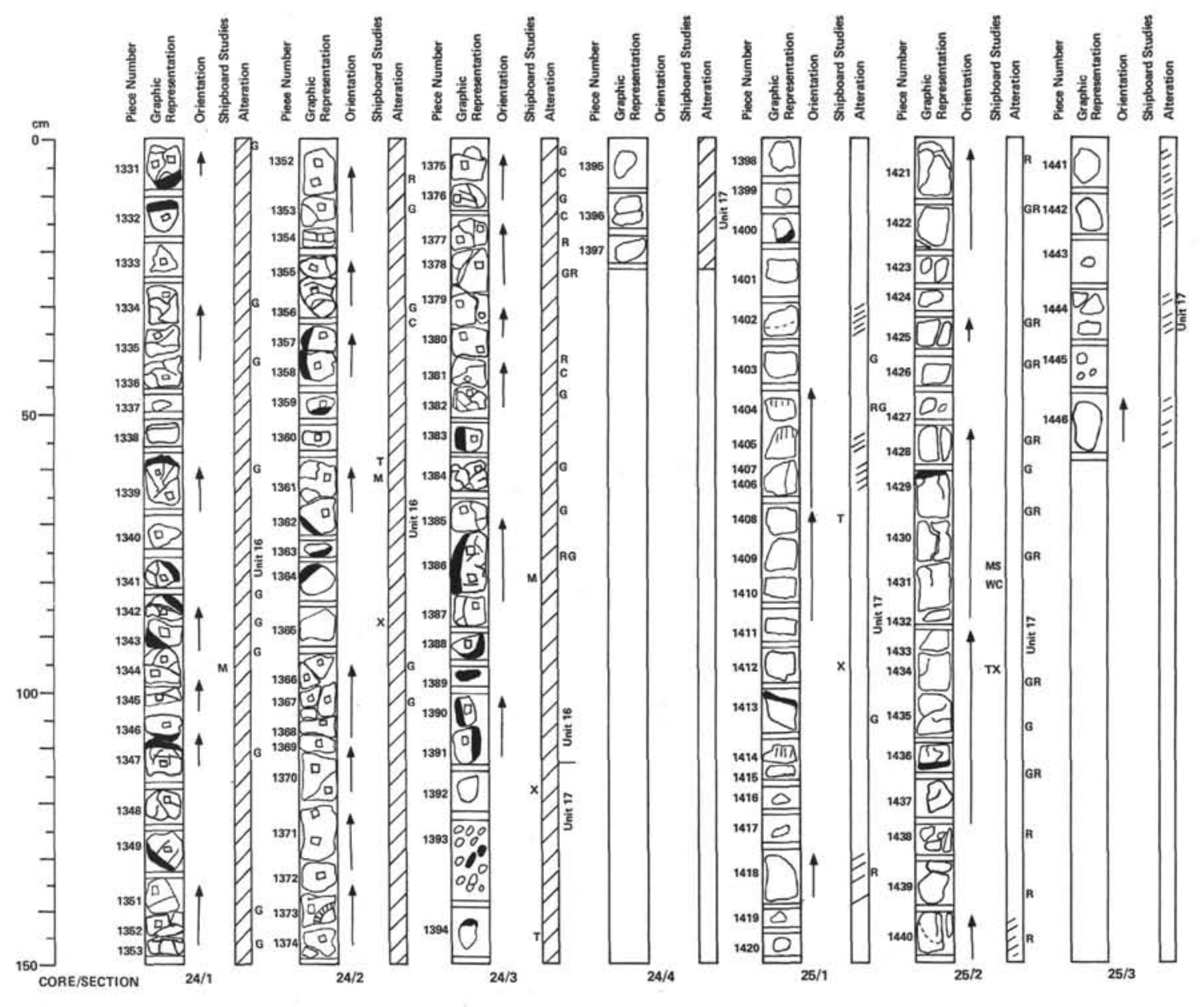

HOLE 5048, CORE 24 - 39125-3925.5 m (4399.0-448.0 mbtrl

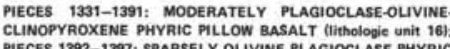
PIECES 1302-1397: SPAASELY OLIVINE PLAGIOCLASE PHYRIC The hascts in in Sactions 241,242 , and most of 24.3 are similar

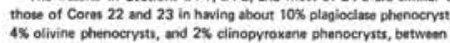

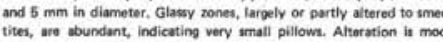

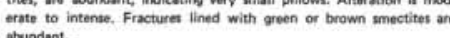

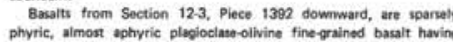

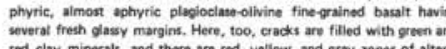

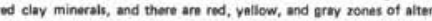

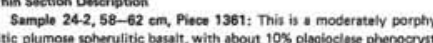

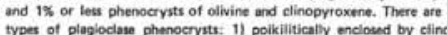

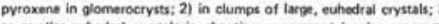

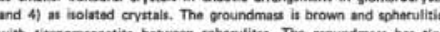

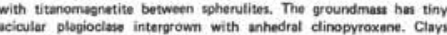

HOLE 5048, CORE 25 3990.0-3936.5 m $1457.0-463.0 \mathrm{mbe}$ APHYRIC OR VEAY SPAASELY OLVVINEFPLAGIOCLASE PHYAIC BASALT litholopic unit 17

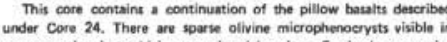

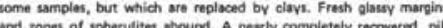

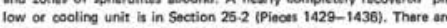

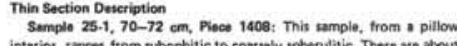

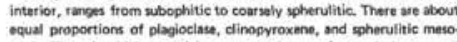

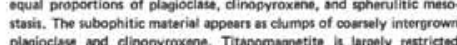

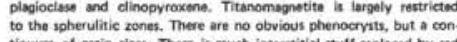

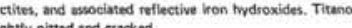

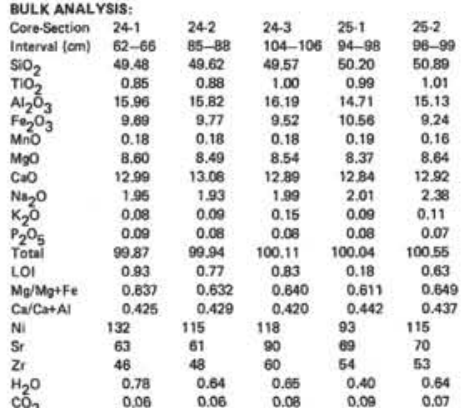
MAGNETIC DATA:

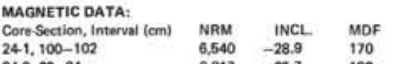

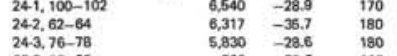

25-2, 83-95
PHYSICAL PROPERTIES

Core Section, interval (cm)

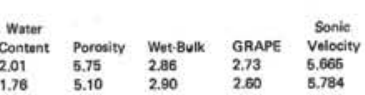

$242,84-65$
$243,7 \rightarrow-78$
253,23

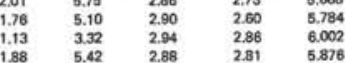




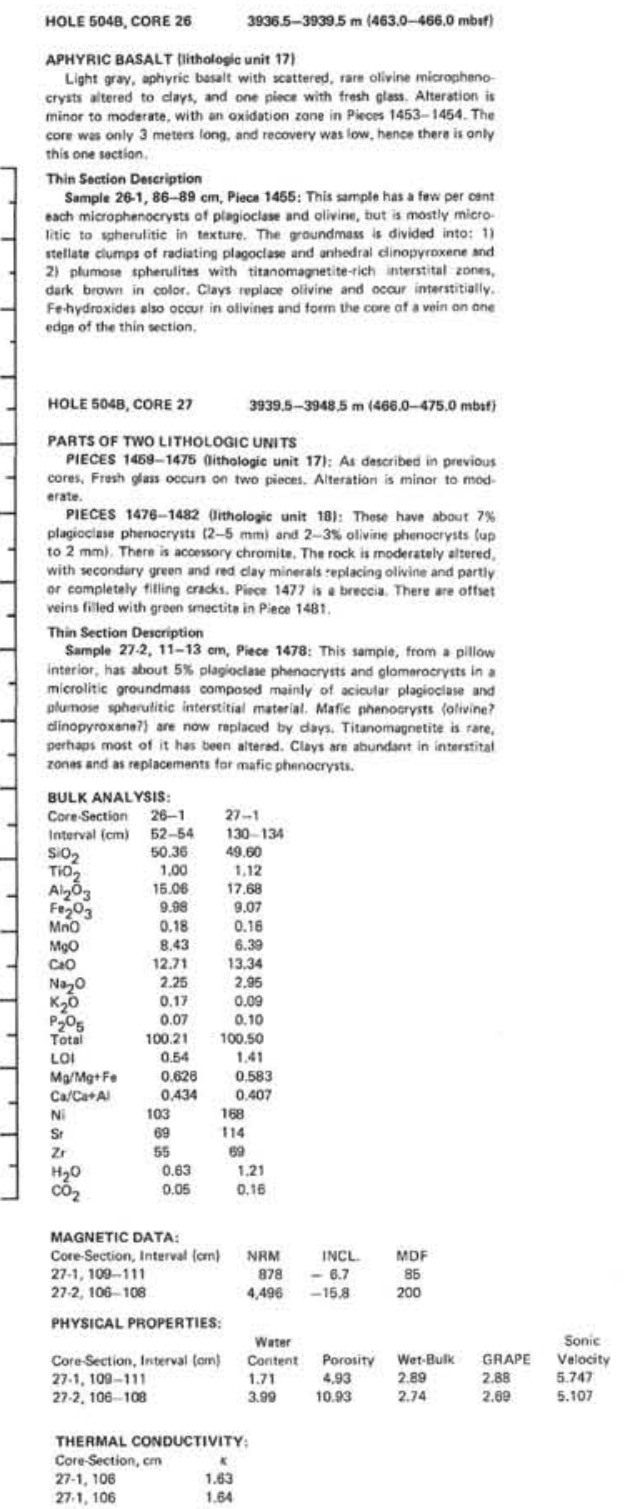




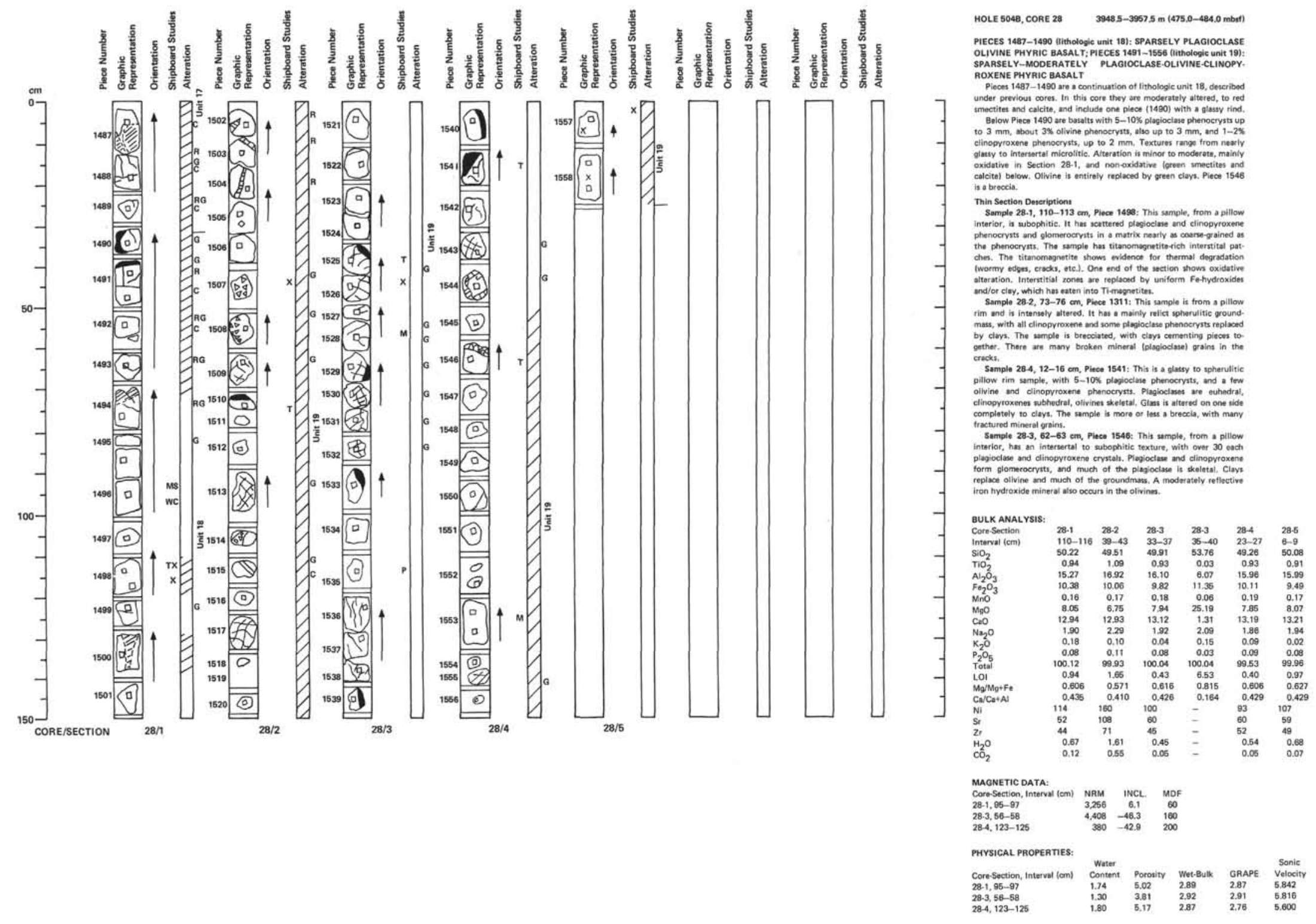




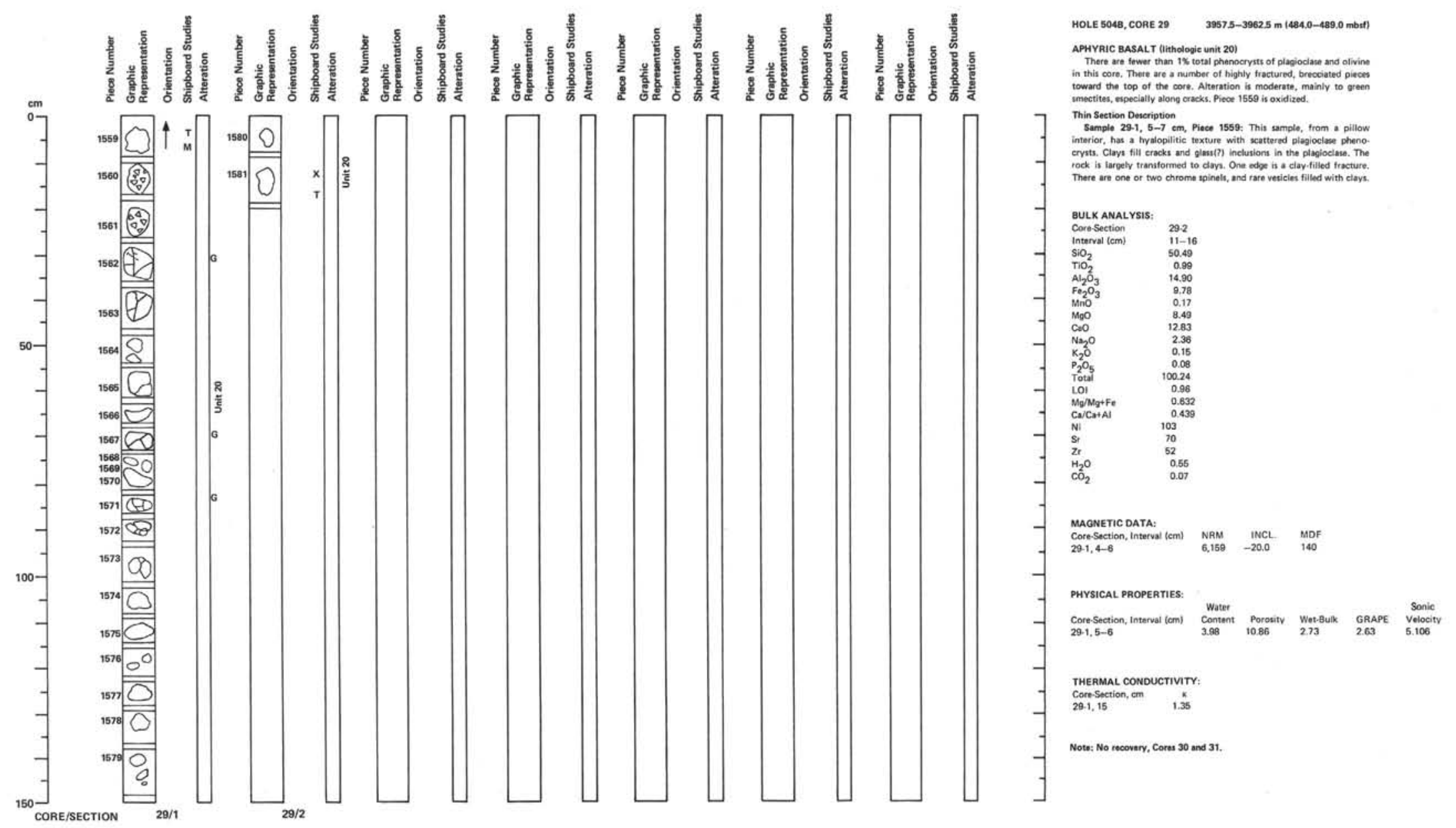




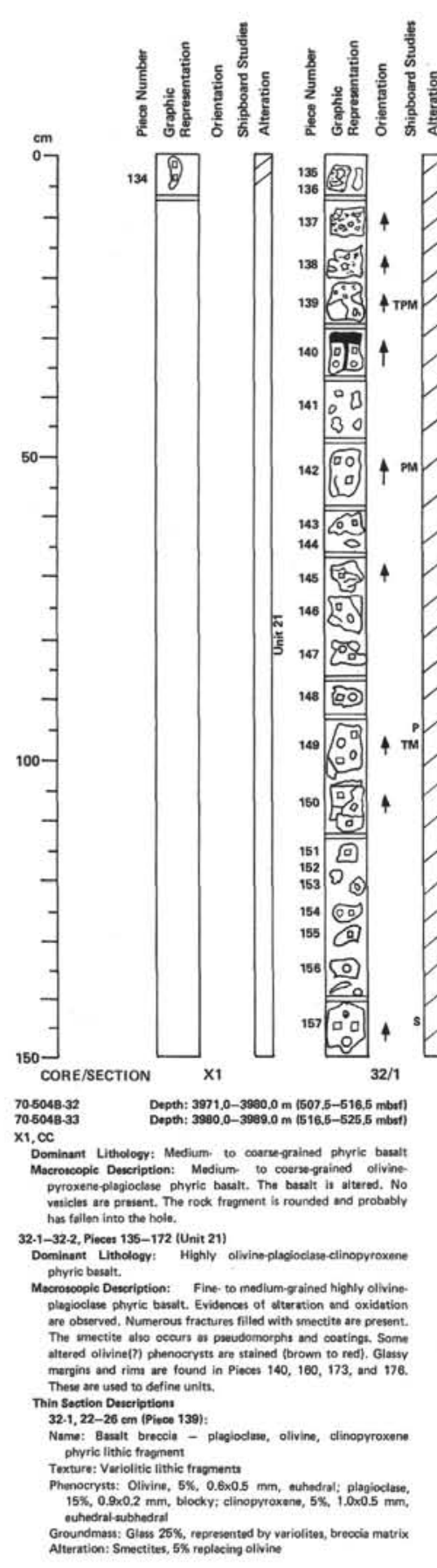

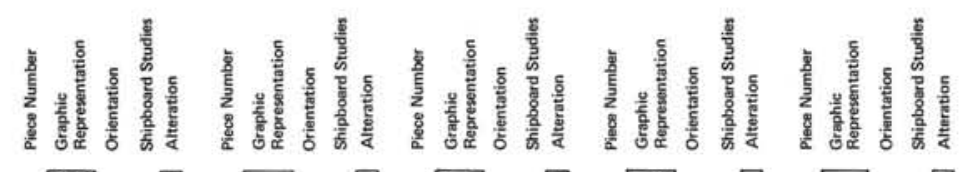

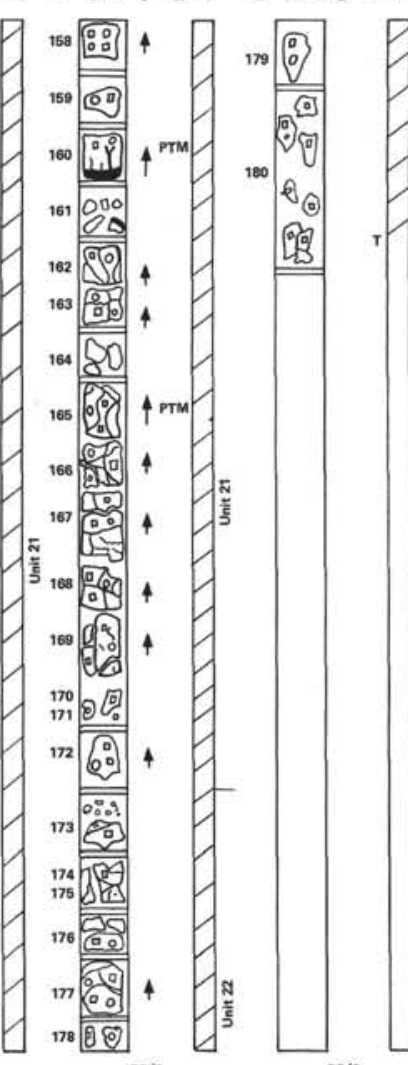

$32 / 2$

32

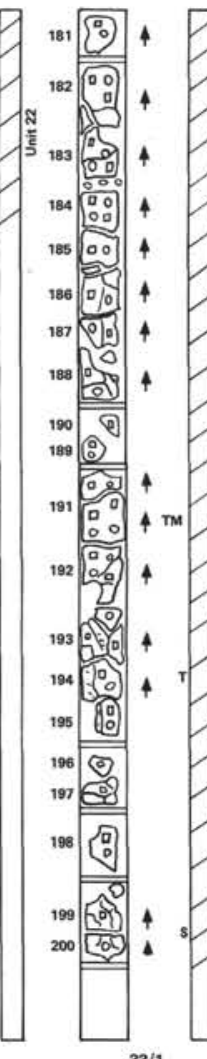

$33 / 1$

32.1, 96-98 em (Piiece 149):

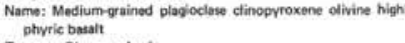

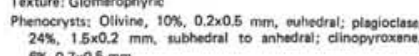

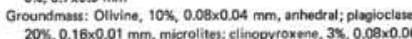

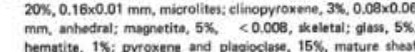

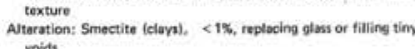
32.2. 19-21 em (Piliece 160 ) Name: Plegiociaste, Otivine, clinopyroxene phyric basat!

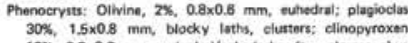

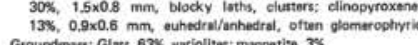

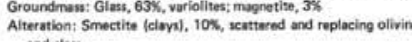
32.2, $55-57$ em (Piece 165):

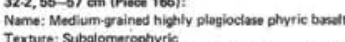

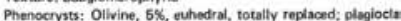

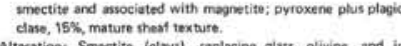

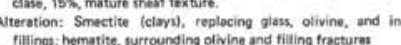
33-1, 73-75 em (Piece 191):

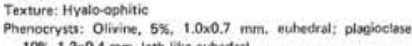

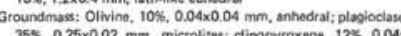

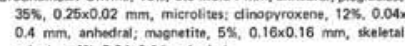

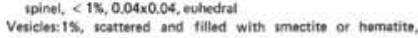

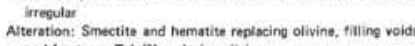

332, 50-62 cm Pilieec 2077:

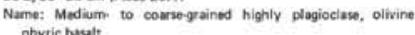

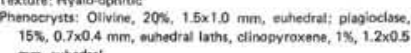

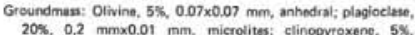

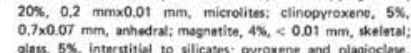

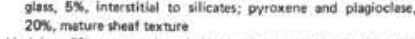

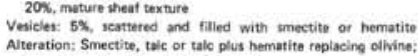

332, $126-129 \mathrm{~cm}$ (Pincest 126 .

wast (moderately Texture. Opplic with soma umal areas of glatu

tupiodesese.

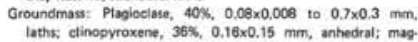

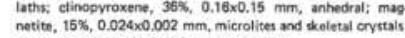

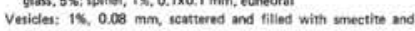

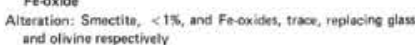
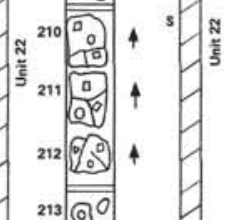

${ }_{214}$

215

${ }_{216}+\mathrm{rm}$

${ }_{217} 170$

$33 / 2$

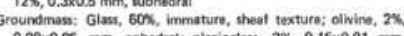

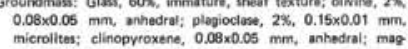

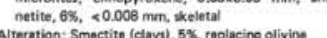

2.22-33:2, Pieces 173-217 (Unit 29

sioclase phrric attered

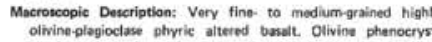

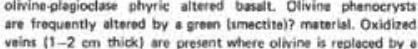

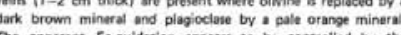

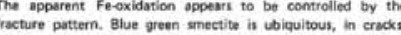

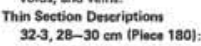

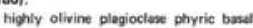

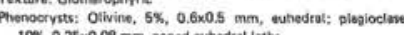

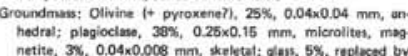




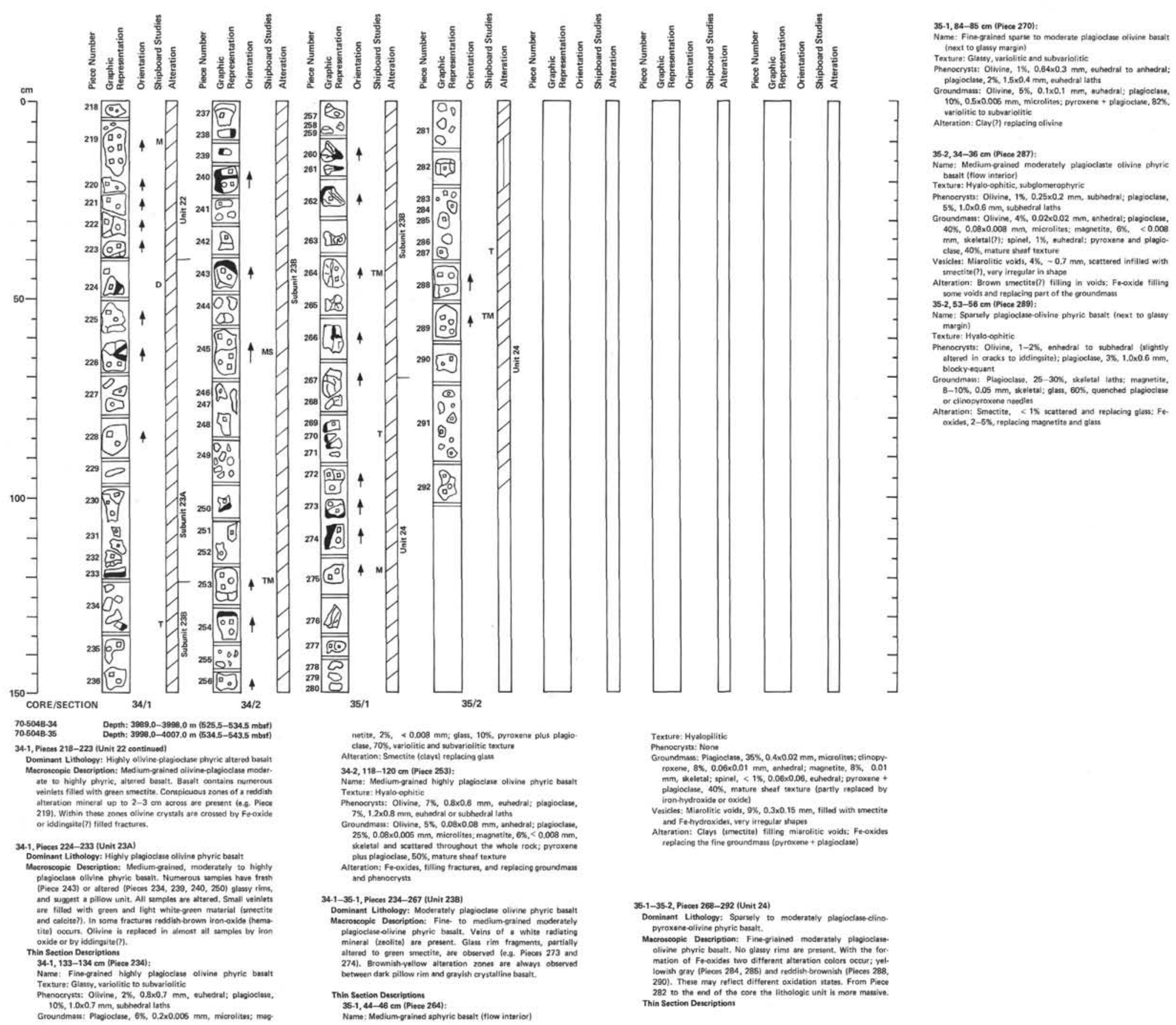




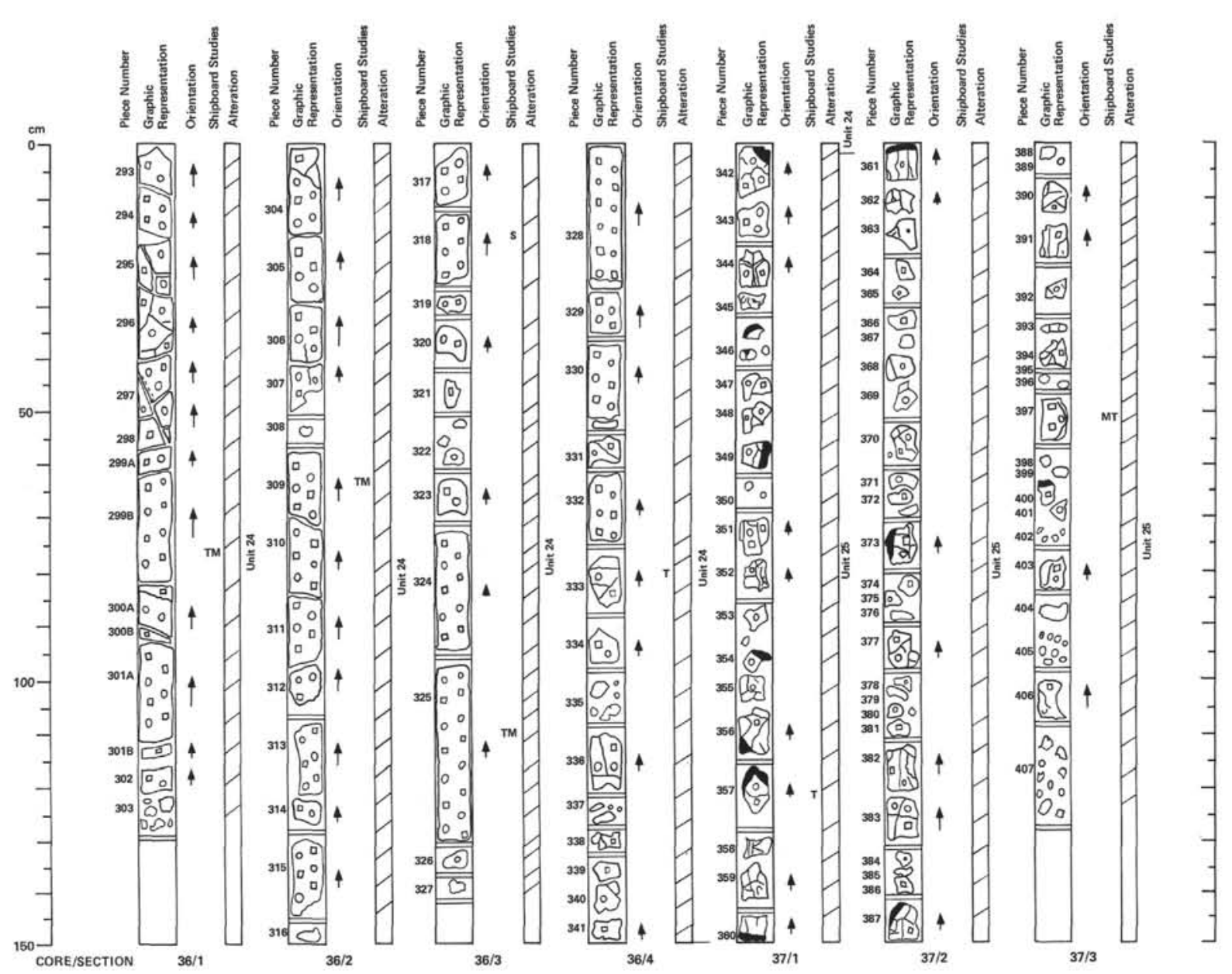

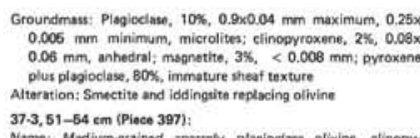

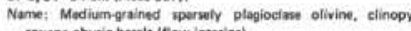
roxana phyric bosatt fliow instrerior

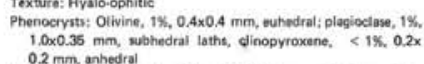

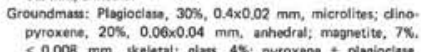

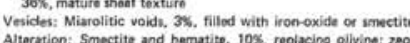

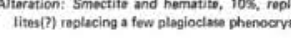

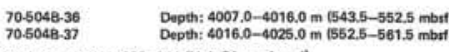

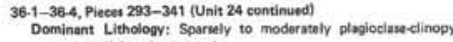

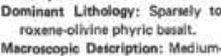

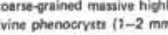

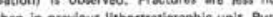

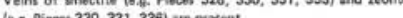

36-1,78-80 on (Fioece 299)

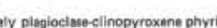
Texurete: Subophiticio to interstrerts

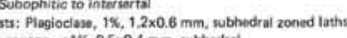

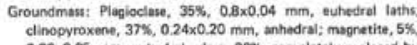

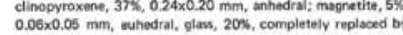
Imectite
Vesicles:

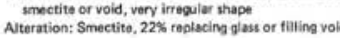

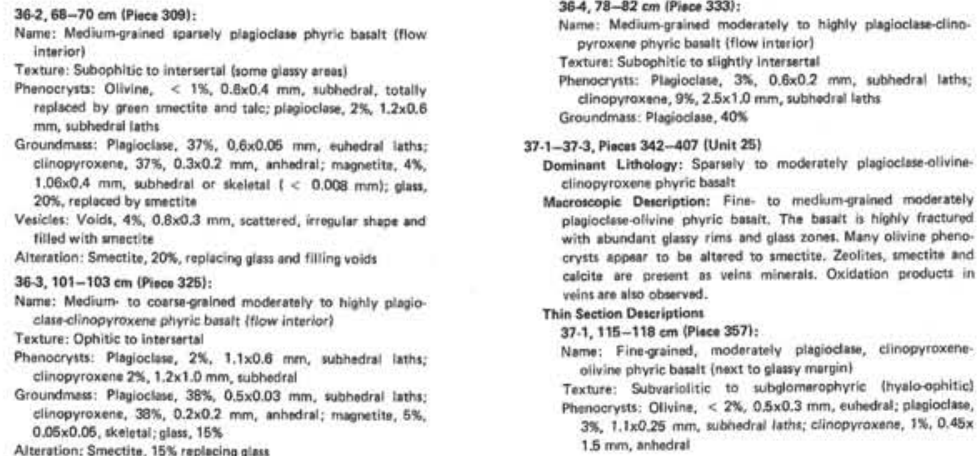




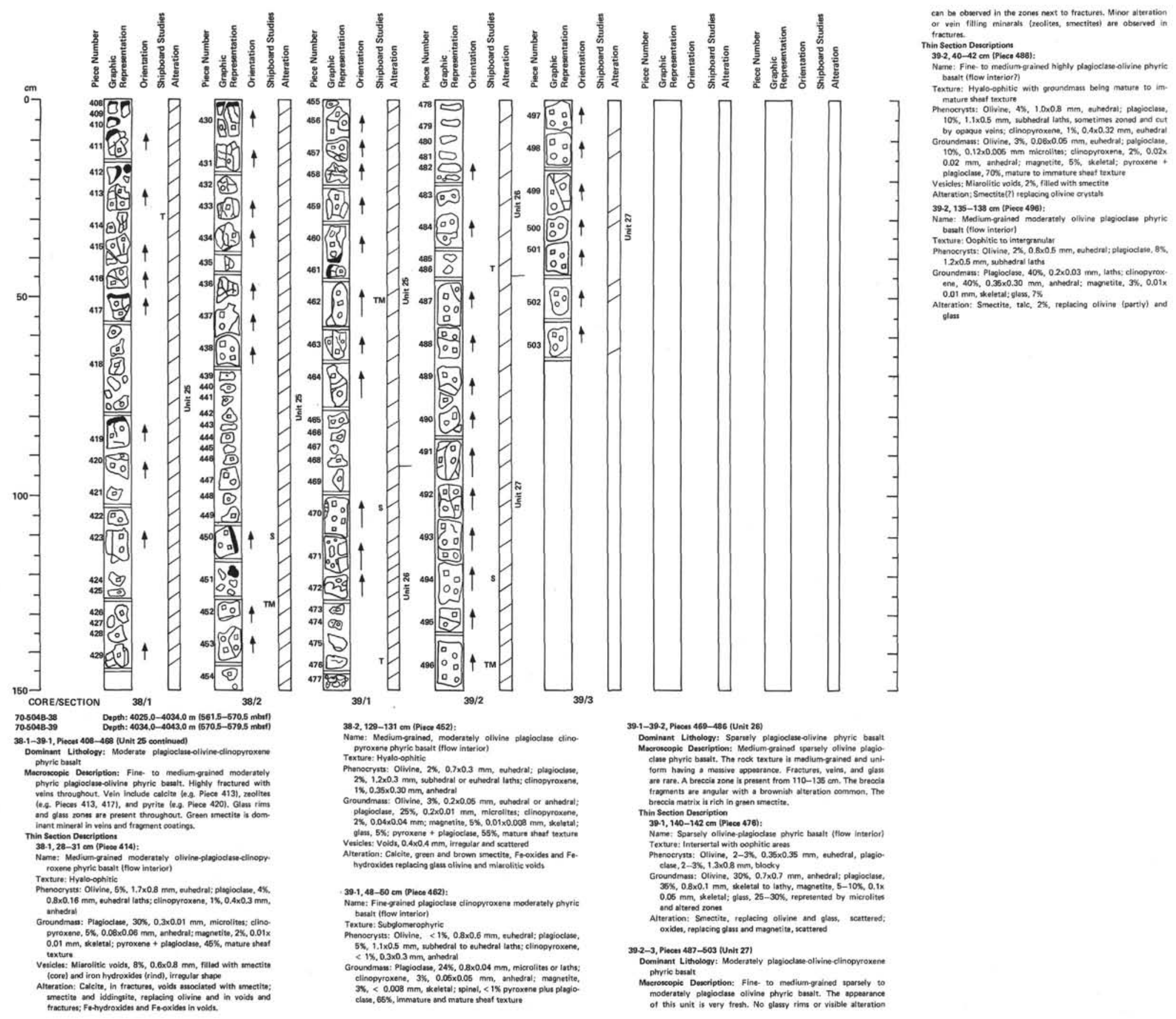




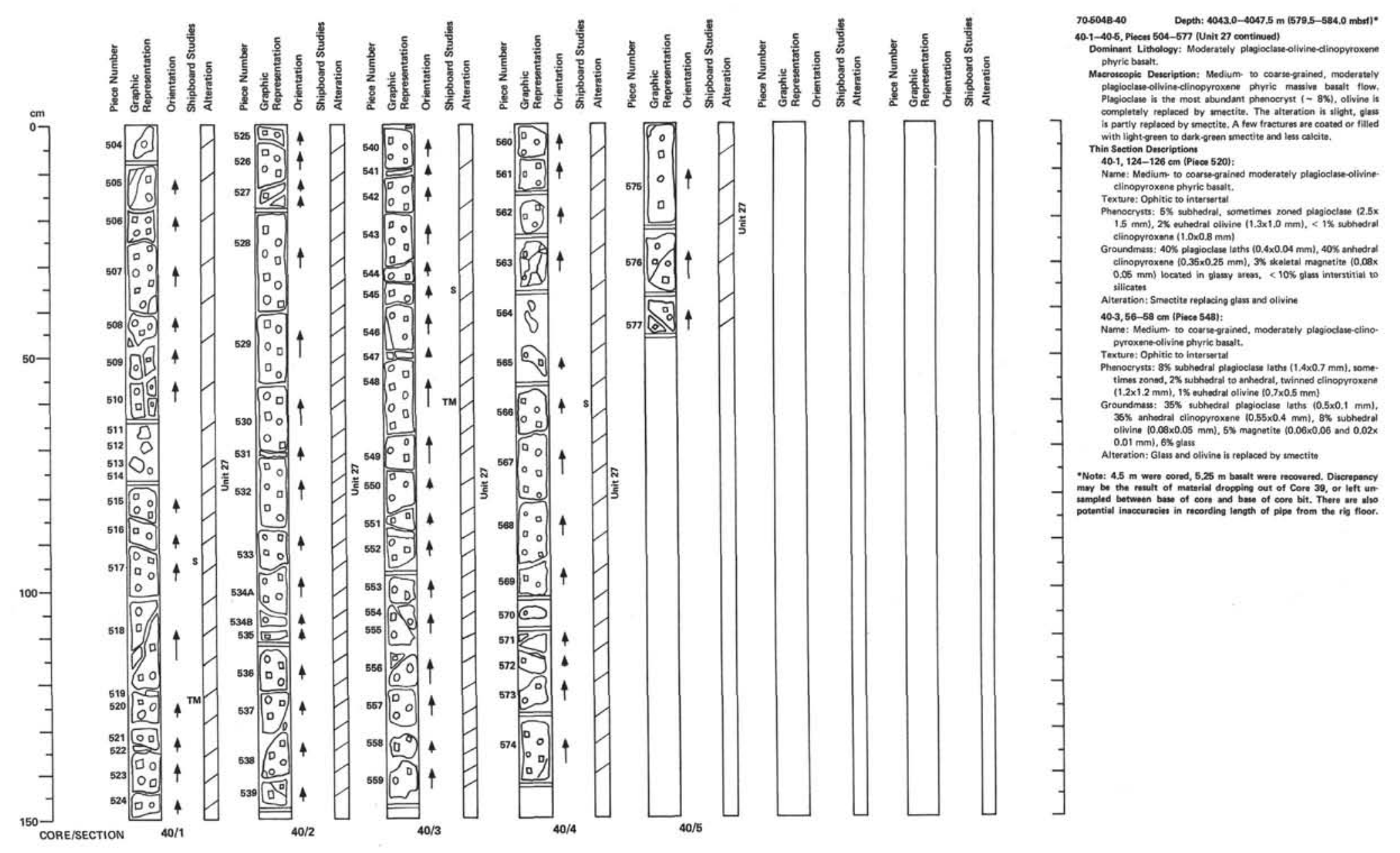




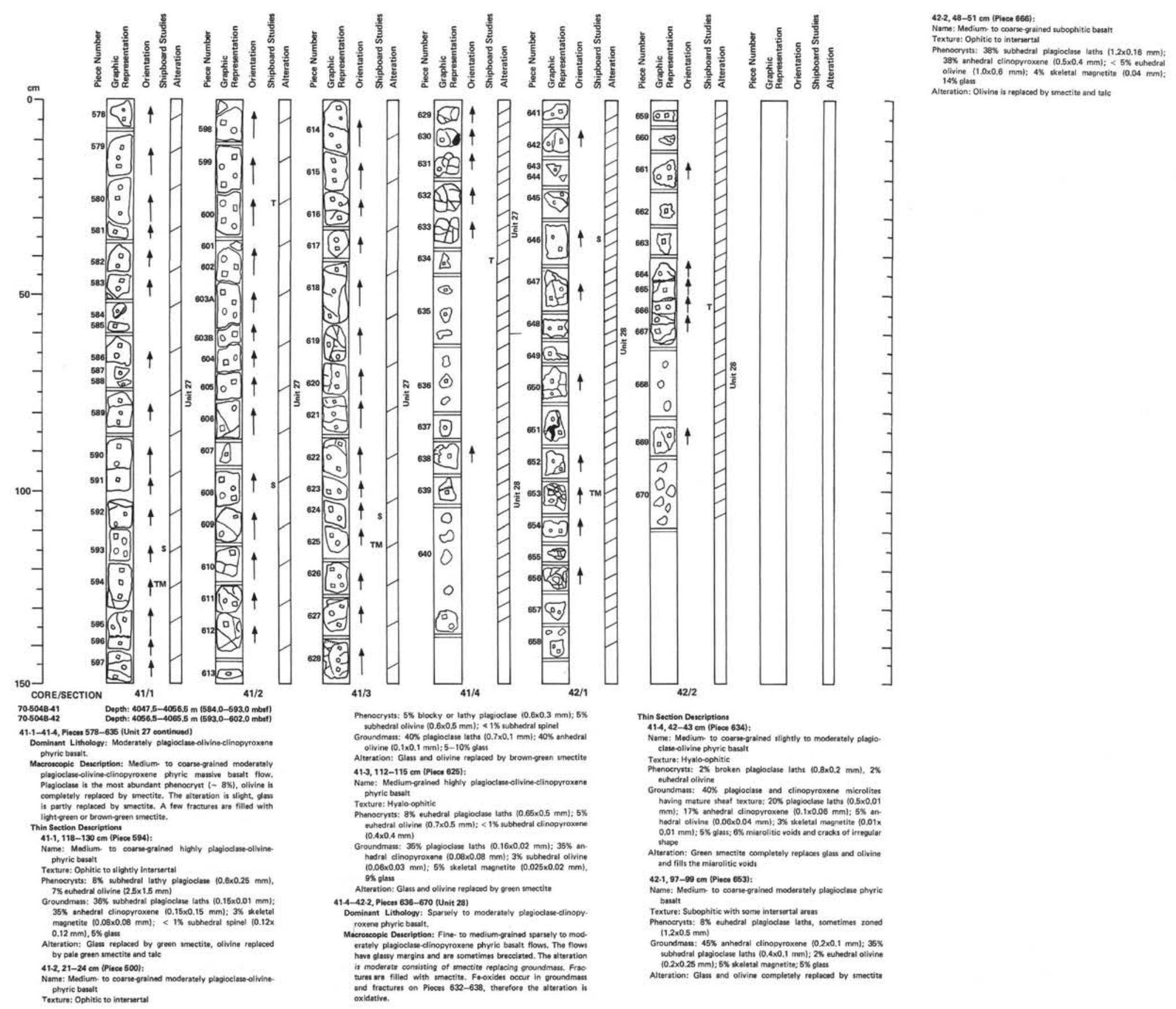




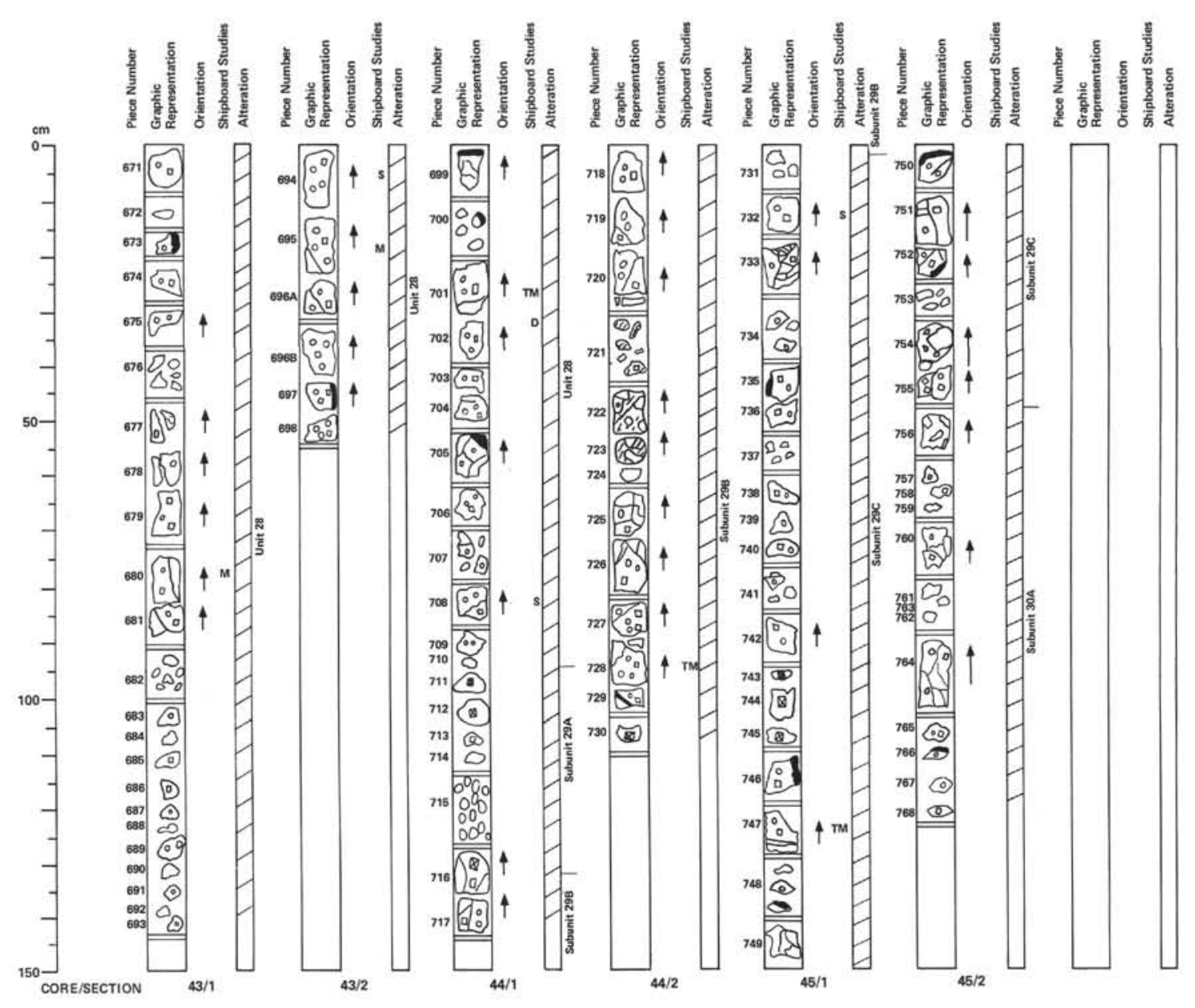

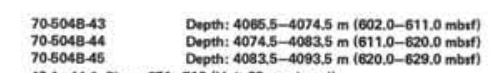
43.1-44.1, Piece 671-710 (Unit 28 continued) Dominast Litholoov: Sparrely to moderately plagiodataedino

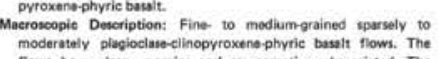
flowt heve glassy maraina mass. Fractures are tiled with snectite. Fe oxiser occur in

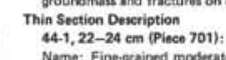

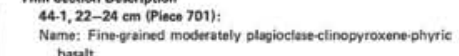

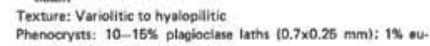
Groundmass: 10X akeliota plagioclase laths $10.5 \times 0.05 \mathrm{~mm})$ :

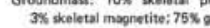

-441, Piecest 711-716 (subunit 29A)

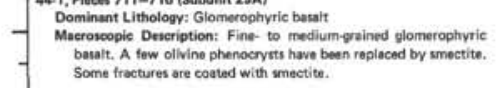

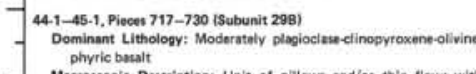

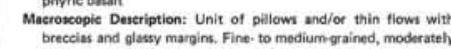

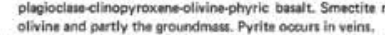

Thin Section Description

Name: Fine, to modiummort

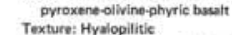

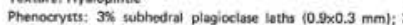

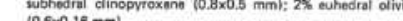
Groundmass: 45

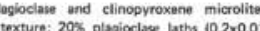

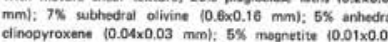

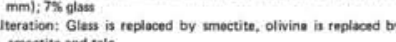
Alteration: Giass is

45.1-45-2, Pilees 731-755 Isubunit 29C

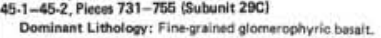

Thin Seetion Desceription
45.1,118-121 cm (Pilecen 747):

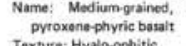

Texare: Hyalo-ophitic

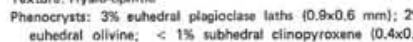

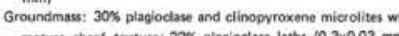

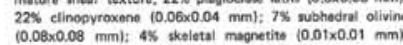

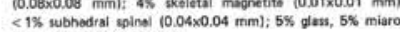

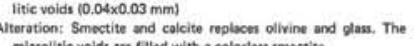

45-2, Pieces 756-768 (Subunit 30A)

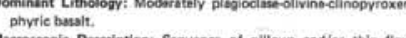

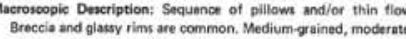

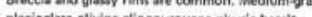




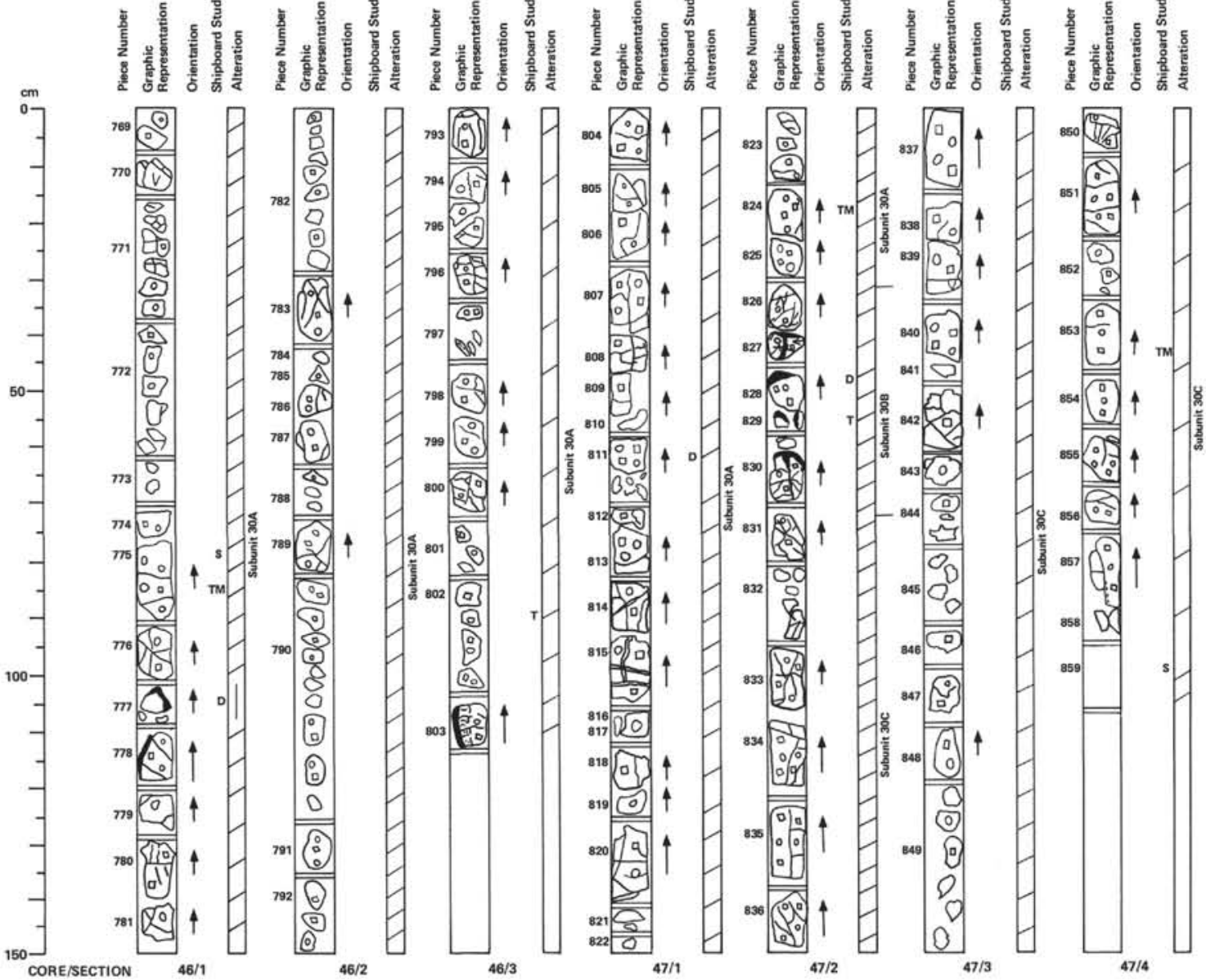




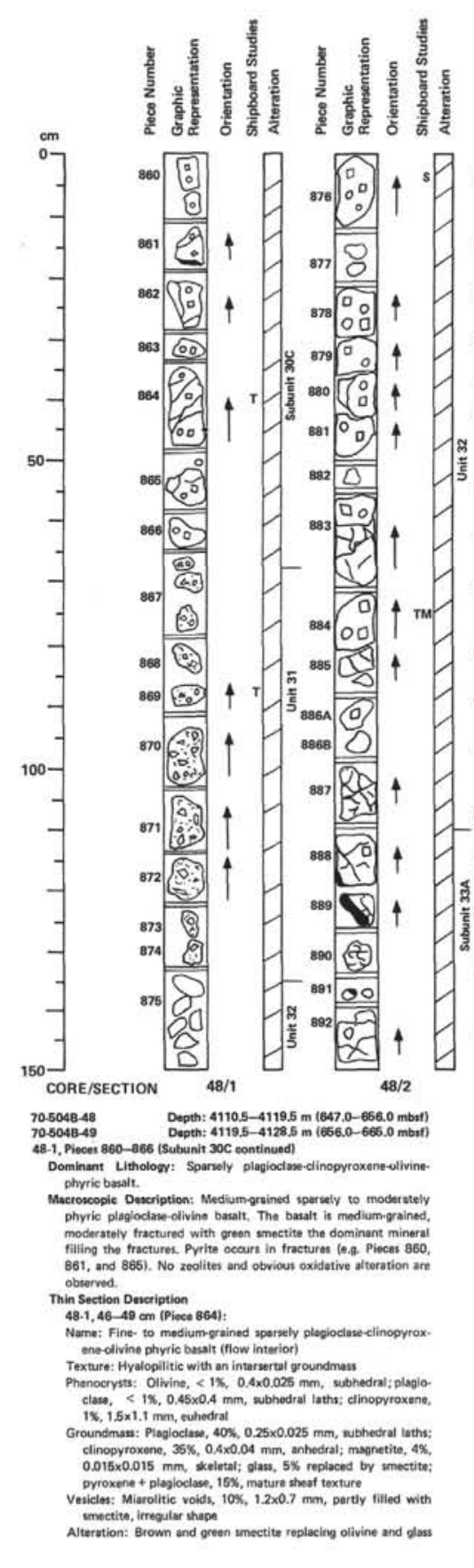

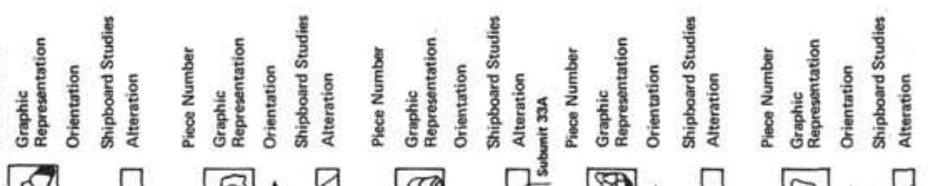

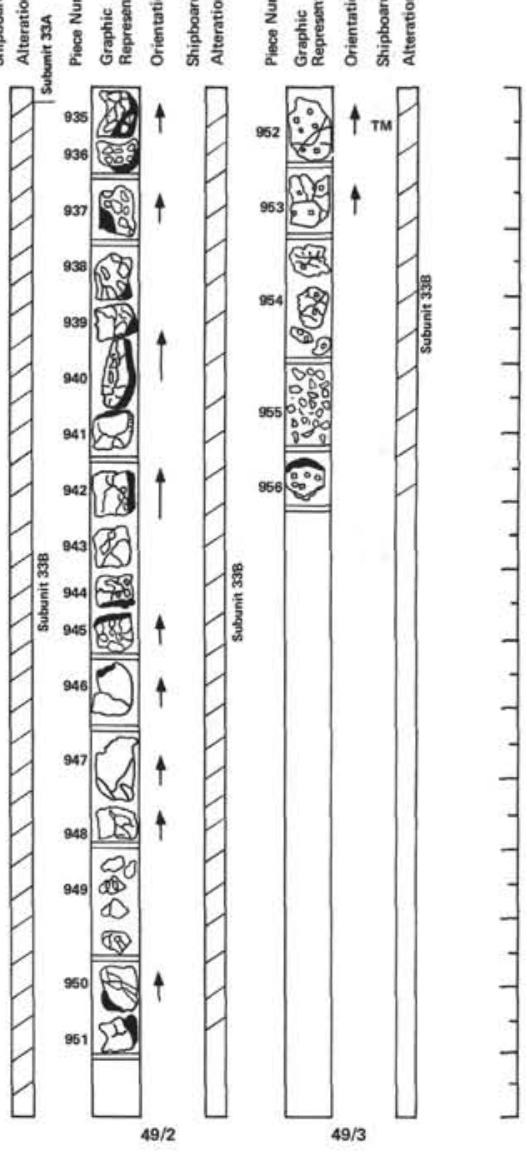

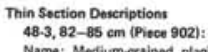

sepphric baselt fllow interior)

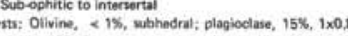

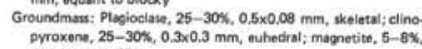

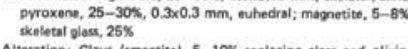

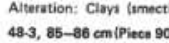

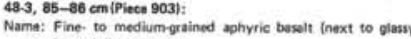
ariolitic patches

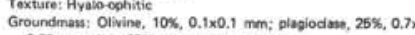

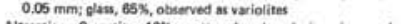
484, 14-16 cm iprioce 910):

lase- dinopyroxene-phyric basat

Phenecryst: Pilagioclase, 20\%, $1.5 \times 0.7 \mathrm{~mm}$, equant: dinoor

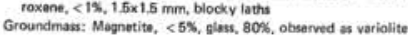
49.1-493, Pitoes 915-956 ISubunit 338)

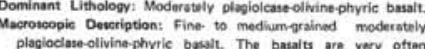

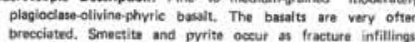

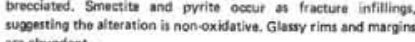

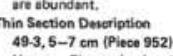

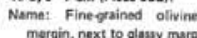

gagiodase-phyric basatt Galats

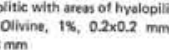

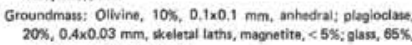

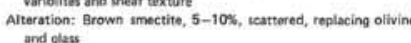

Thin Seetion Doseciption
$482,75-78$ cm (P.ieace 884)

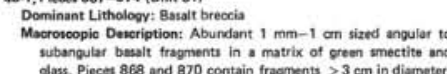

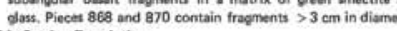
48.-1,90-92 em (P.iece 869): Name: Besalt breccin (glassy margin)

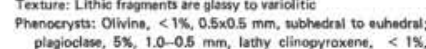

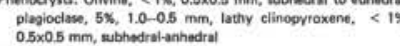

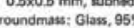
Altaration: Smectite resilecing ofiqinal matrix and glassy trog 48.1-48.2, Piecos 875-887 (Unit 32)

indasedinop

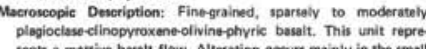
frectures where smectite end pyrite ate found. Olivine is at

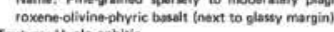

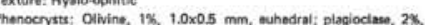

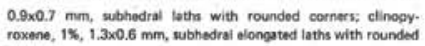

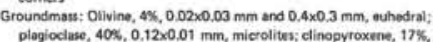

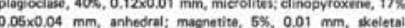

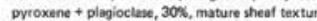

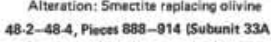

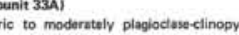

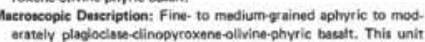

represents a pillow sequenoe with possibly a small flow in the

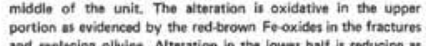

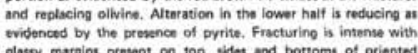

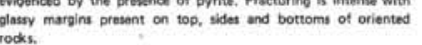



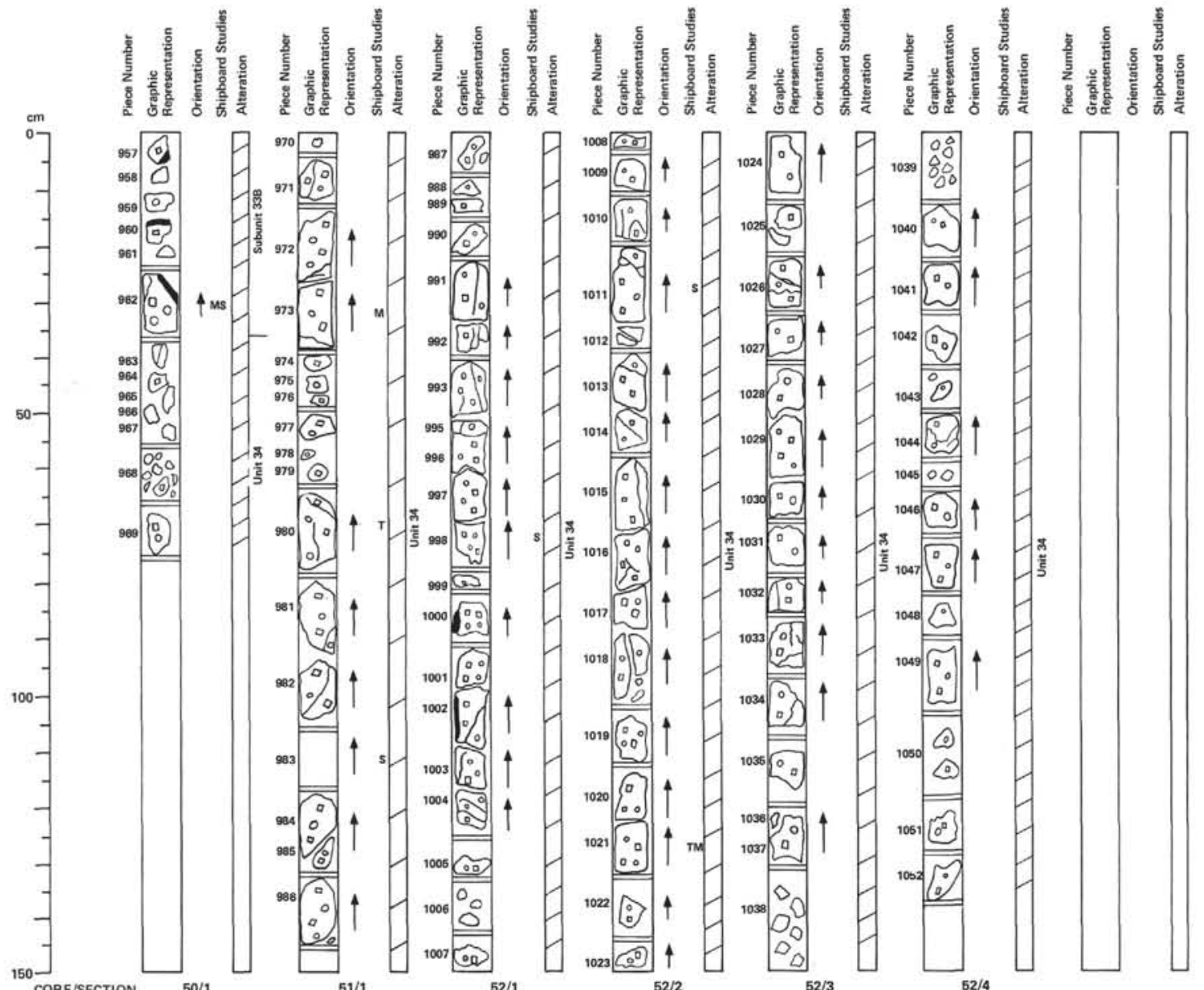

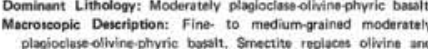

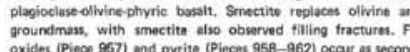

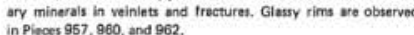

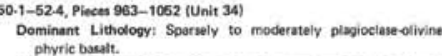

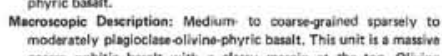
course ophitic besalt with o dessy margin at the top, Olivine

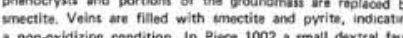

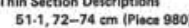

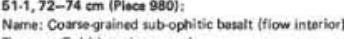

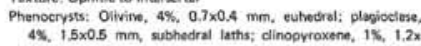

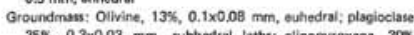
$35 \%, 0.3 \times 0.03 \mathrm{~mm}$, whbhodral laths; slinopyroxene, $30 \mathrm{~K}$

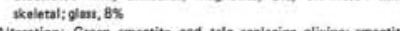

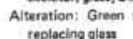

52.2, $132-134$ cm (Pineso 1021): Name: castograined w wbop

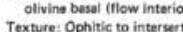

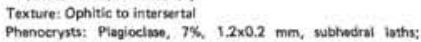

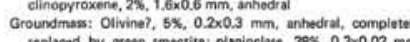

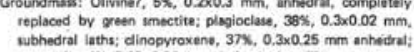

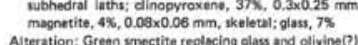




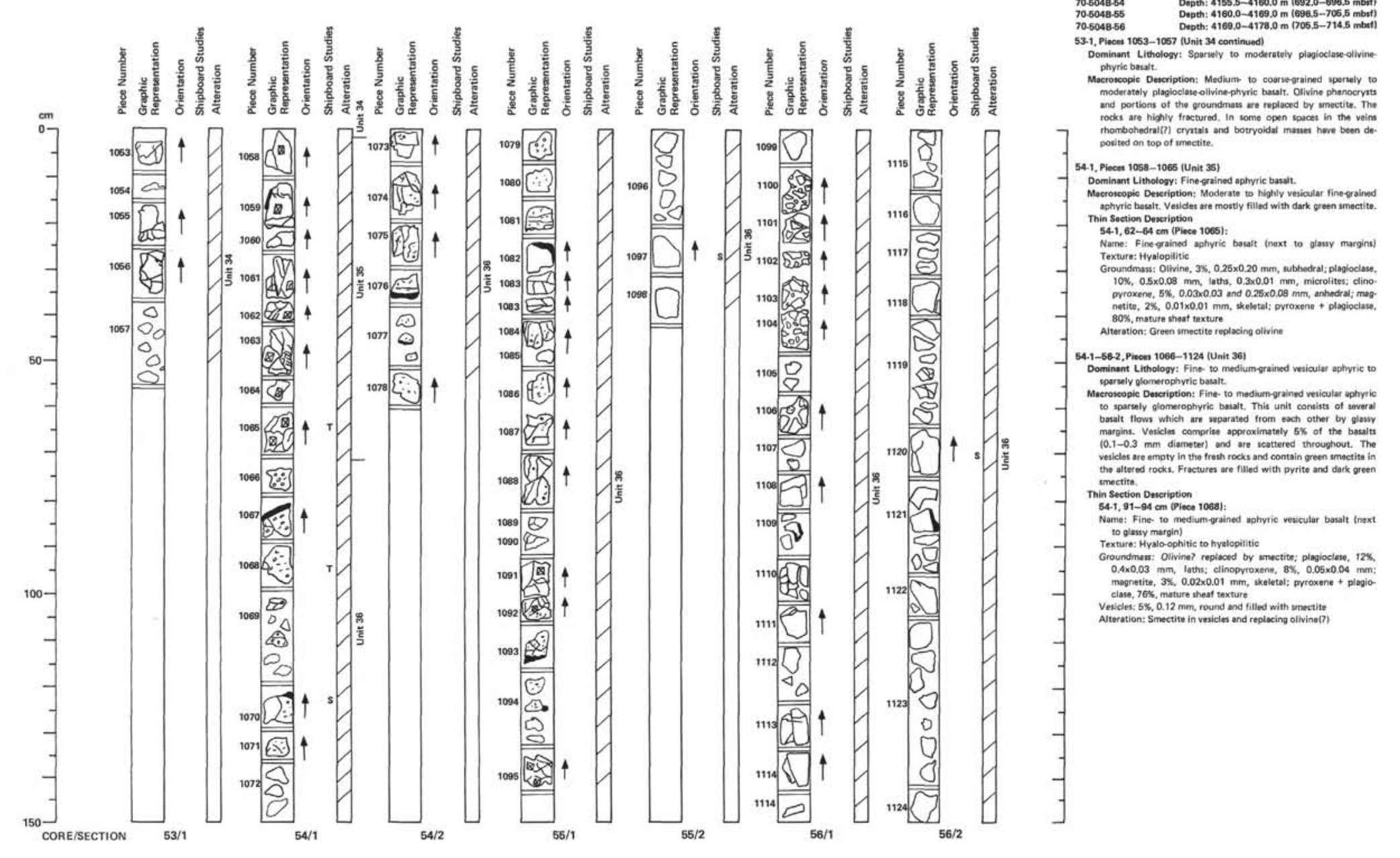




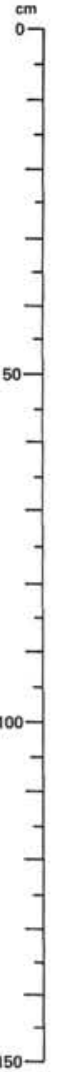

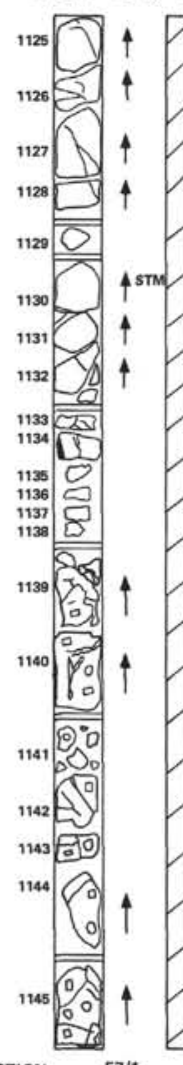

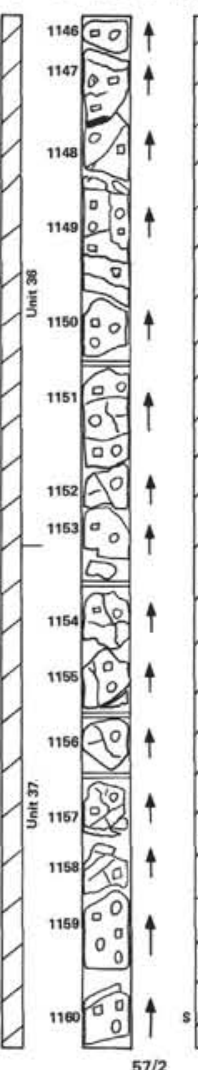

$57 / 2$

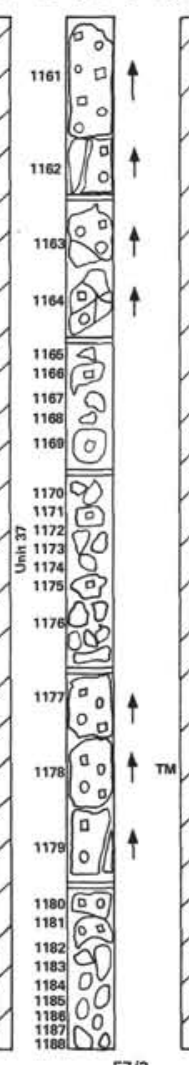

$57 / 3$

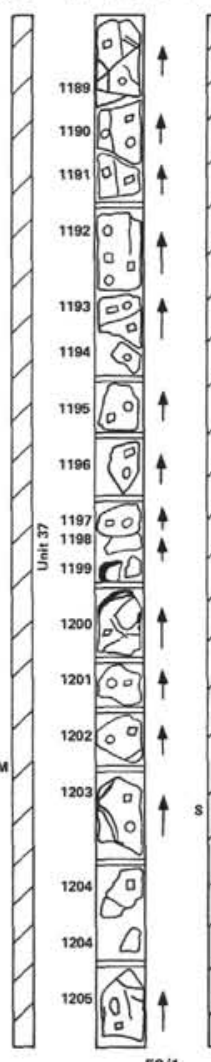

$58 / 1$

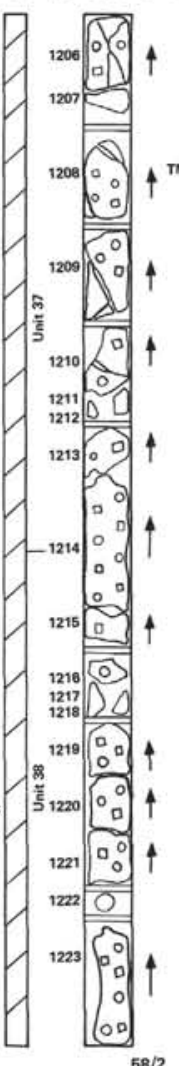

$58 / 2$

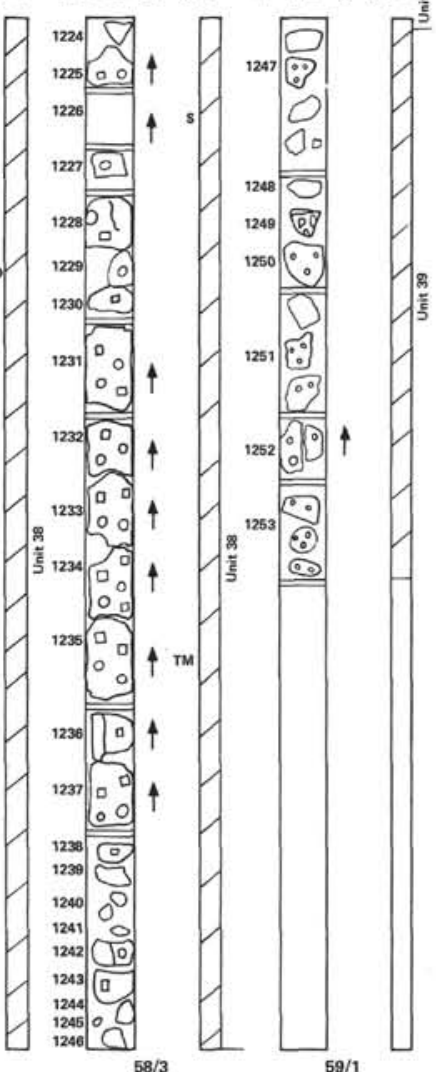

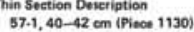

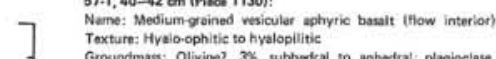

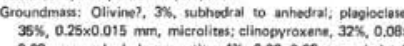

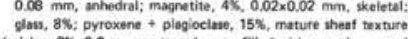

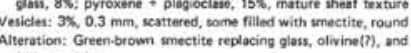

57.1-58.1, Pincent 1139-11988 (Unit 3)

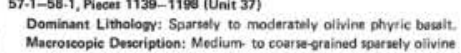

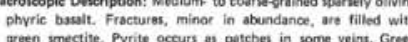

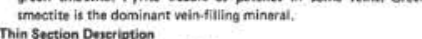

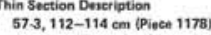

Neme: Medium to conss-yrain

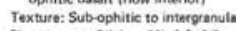

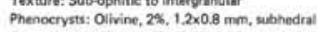

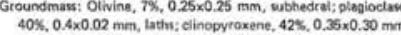

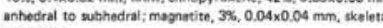

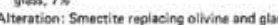

53-1, Pitieat 1199-1246 (Unit 391

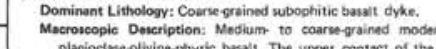

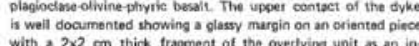

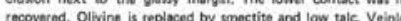

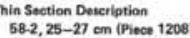
Mnicic basal thiow interior)

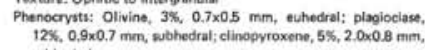
whobecart

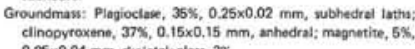

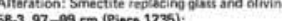

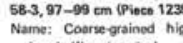

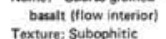

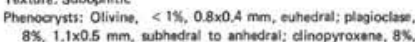

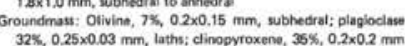

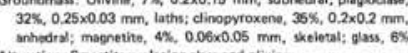

59-1, Priceses 1247-1253 (Unit 39 )

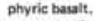

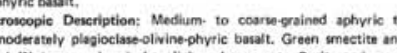

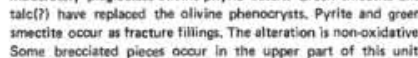




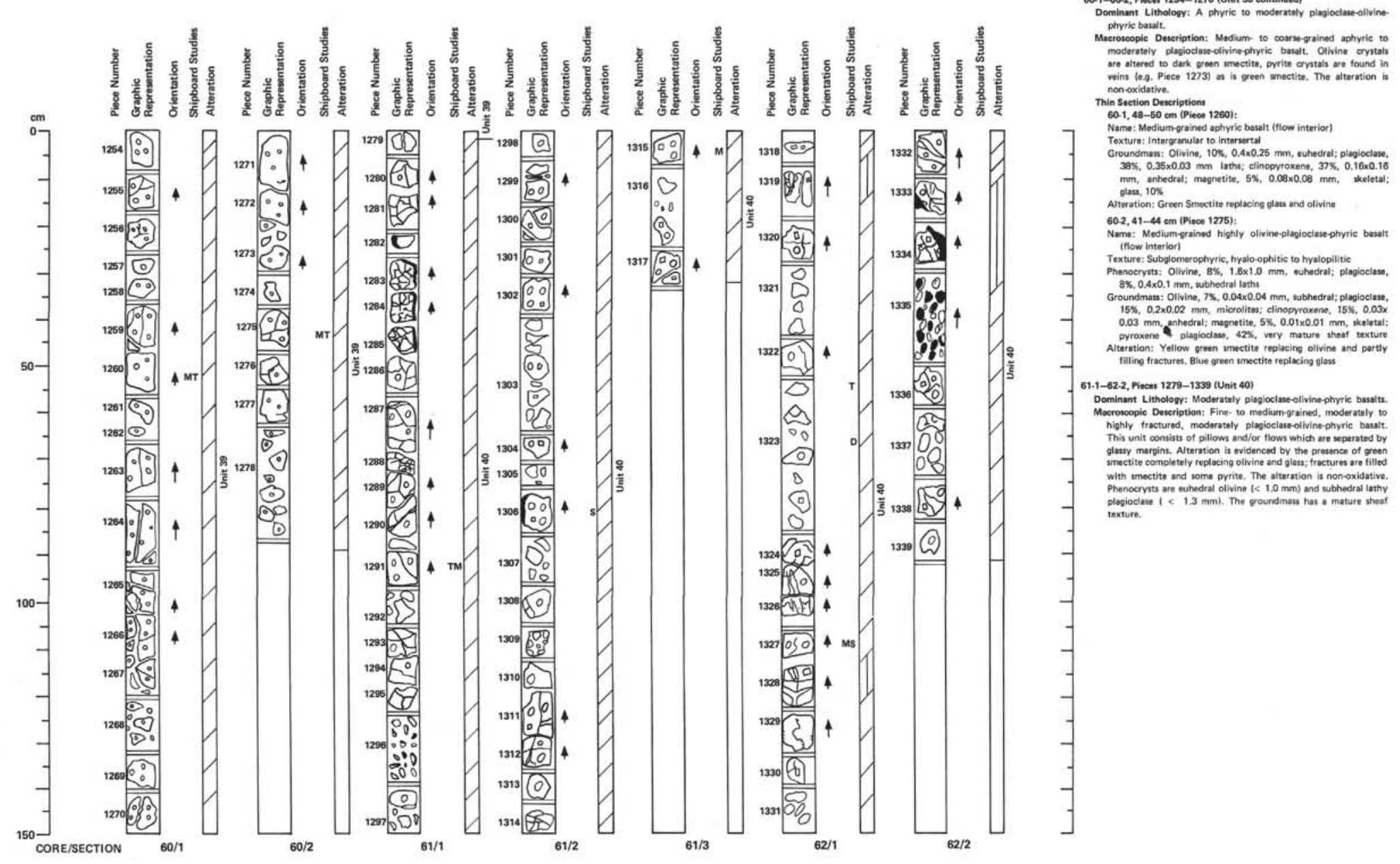




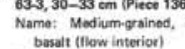

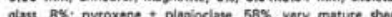

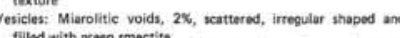

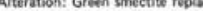

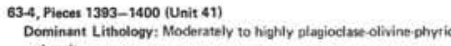

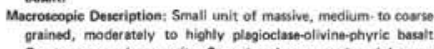

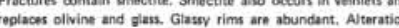

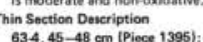

634,45-48 $\mathrm{cm}$ (Pioce 1395)

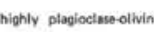

Texture: Subbophitic to intersers

Phenocysta: Olivine, 5x, $0.8 \times 0.2 \mathrm{~mm}$, euthedrat; placiociast.

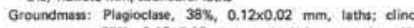

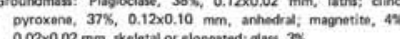

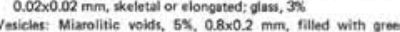

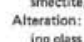

634, 60-61 cm (Pisece 1400 )

Name: Modium ratrainod hid

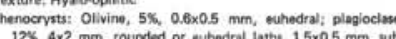

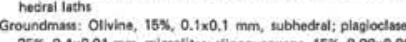
mm, anhectral; magnetitio, $8 \%, 0.03 \times 0.03 \mathrm{~mm}$, skoletal; glus.

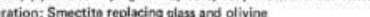

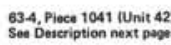




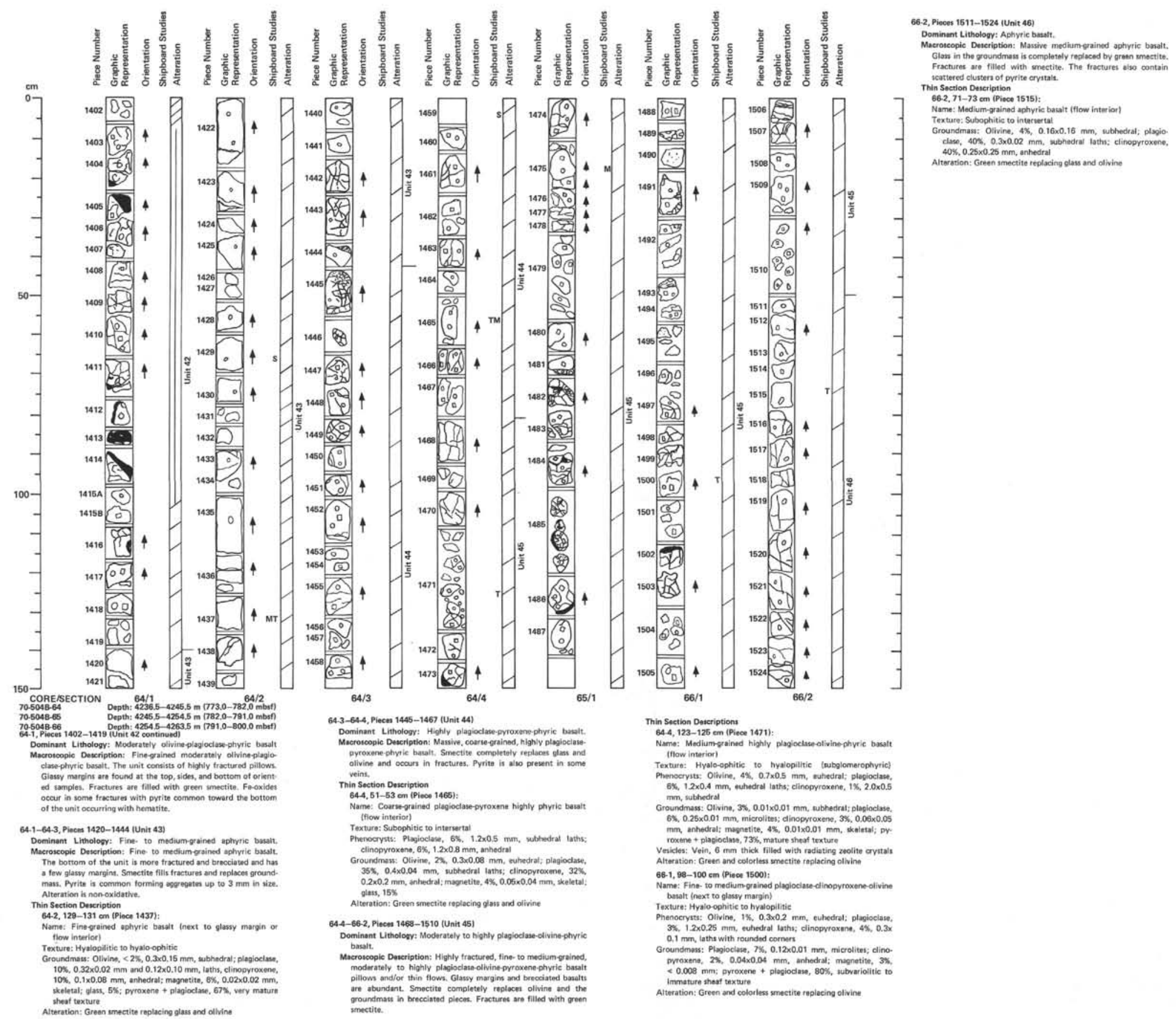




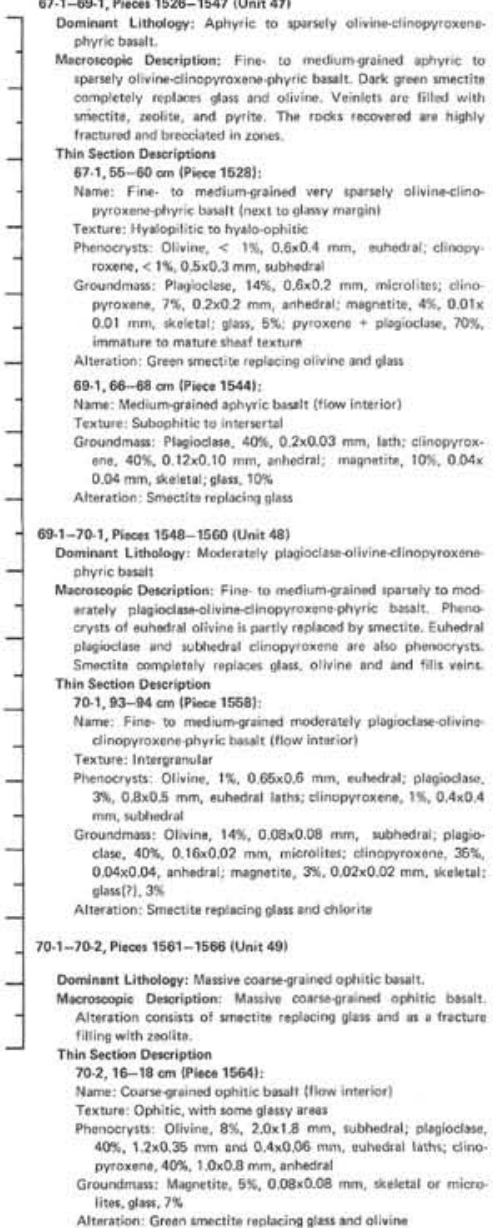$$
\text { (n) }
$$

$$
\text { (1) }
$$

$$
70 / 2
$$




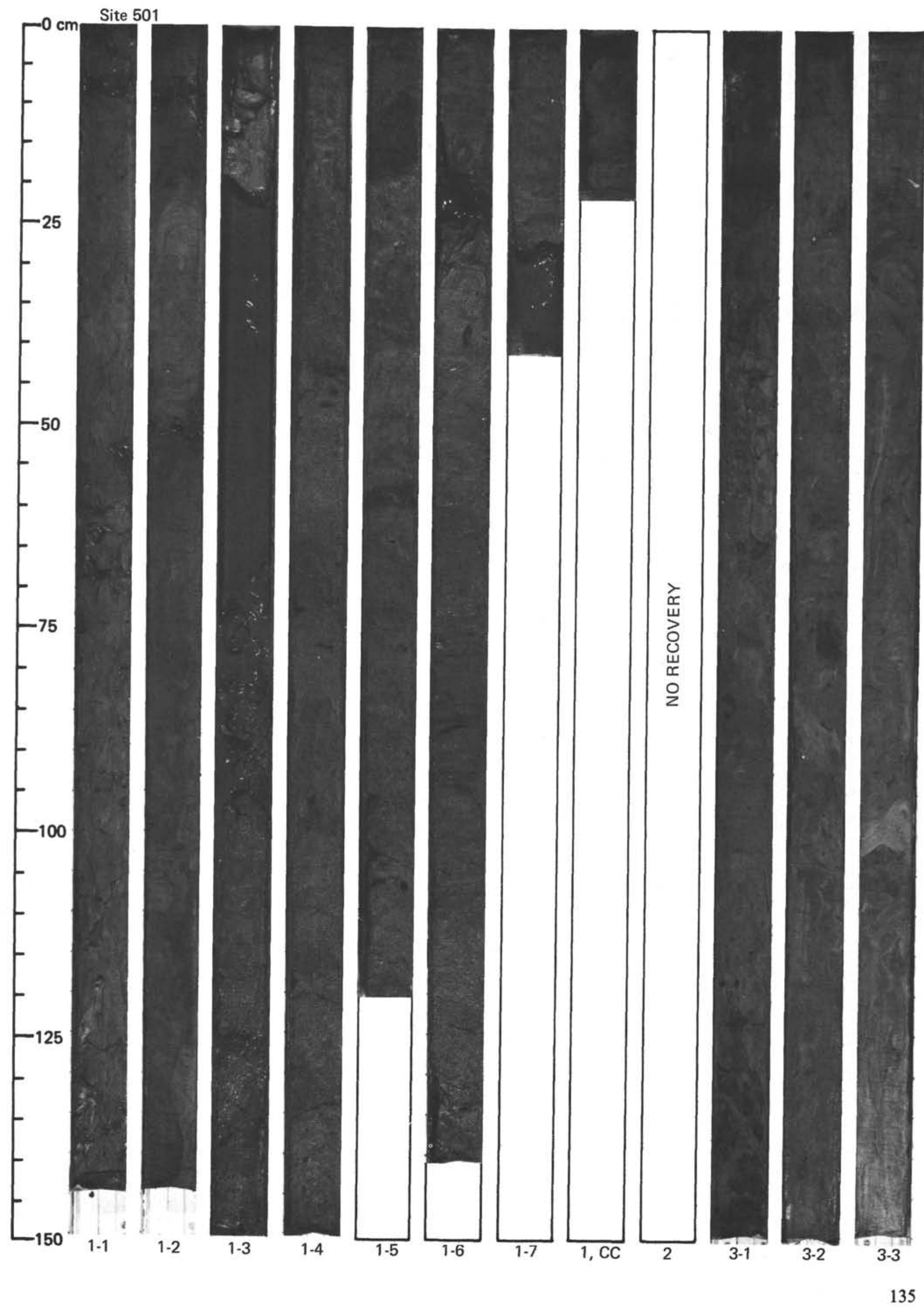




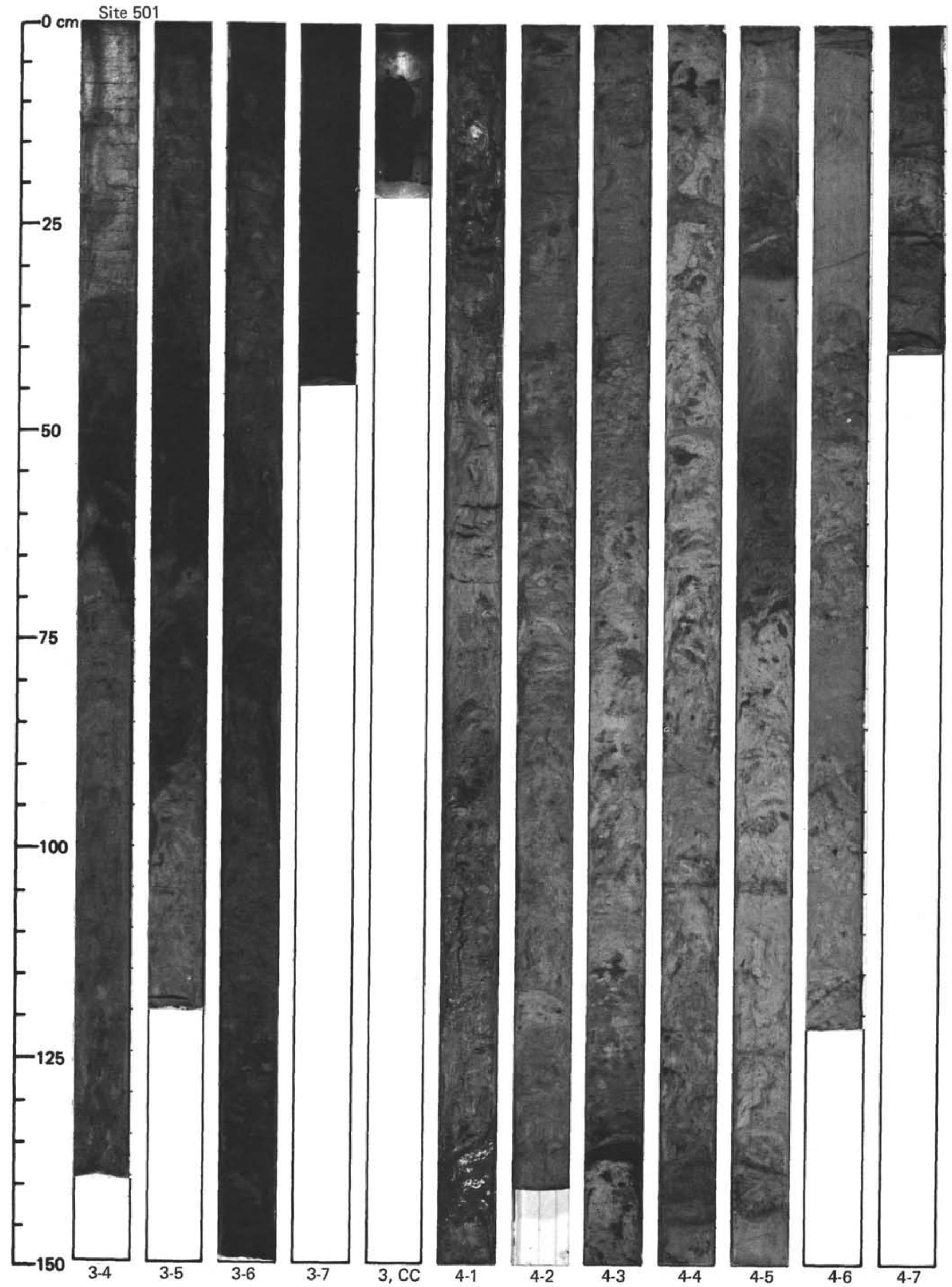




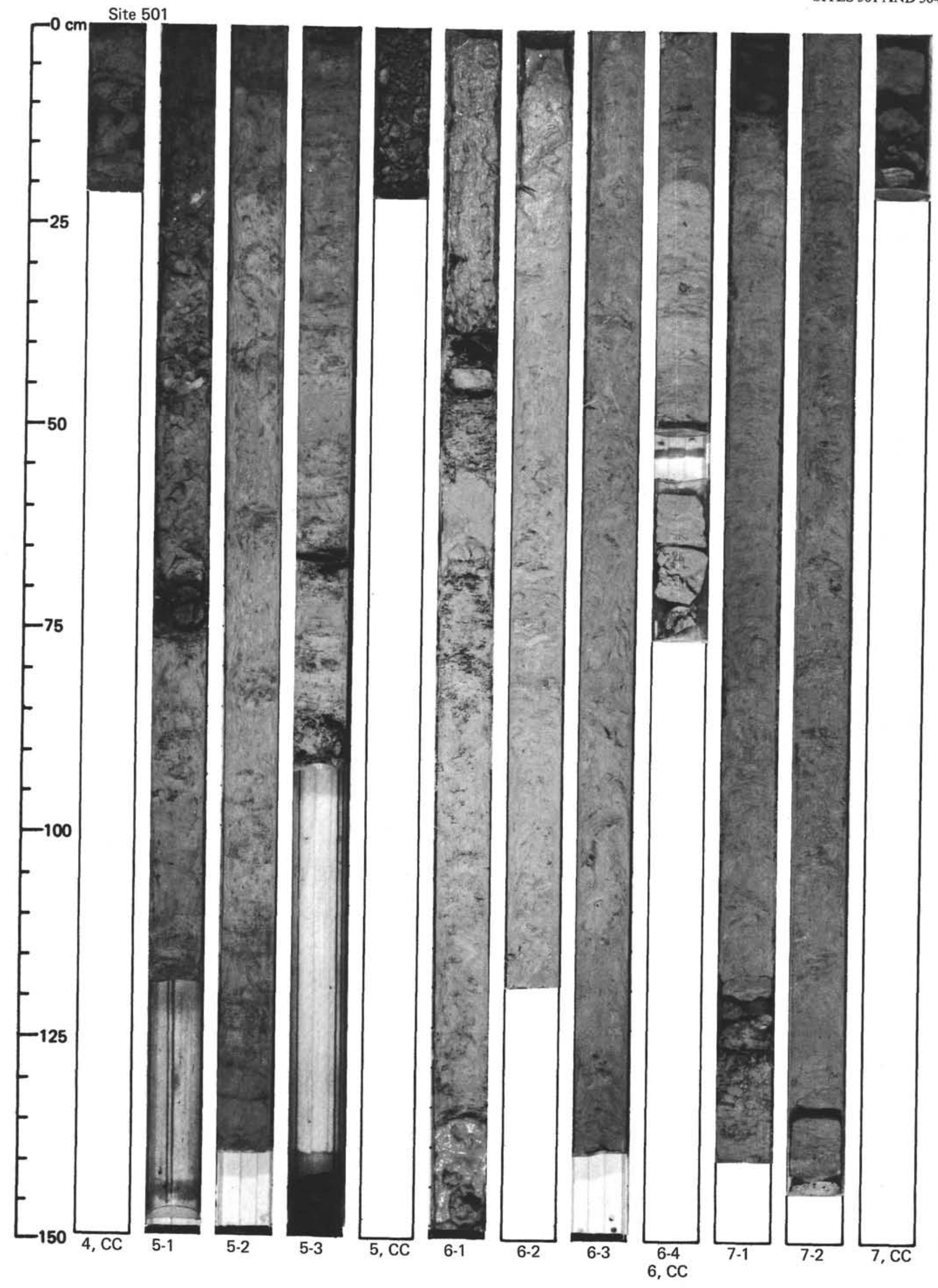




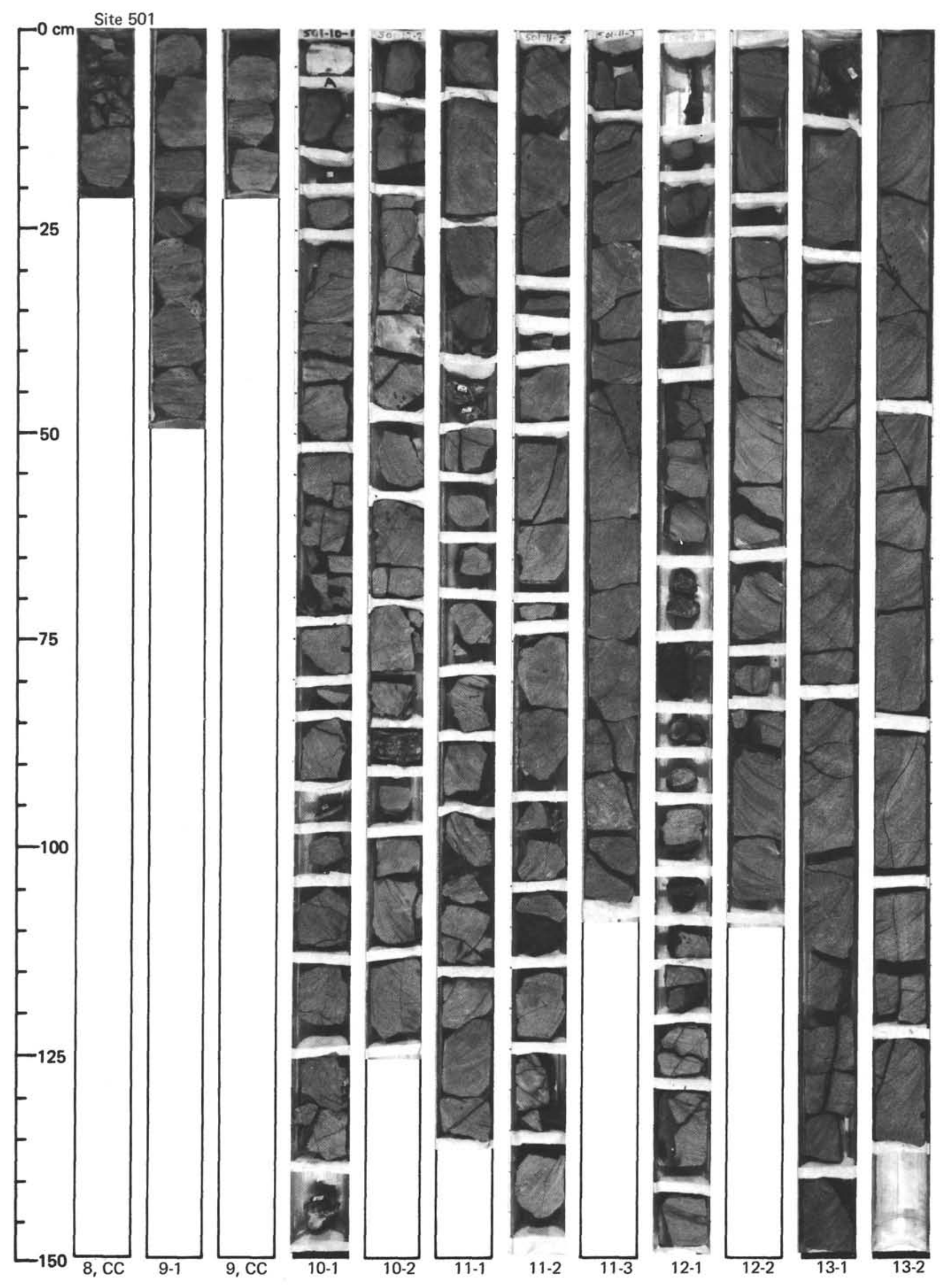




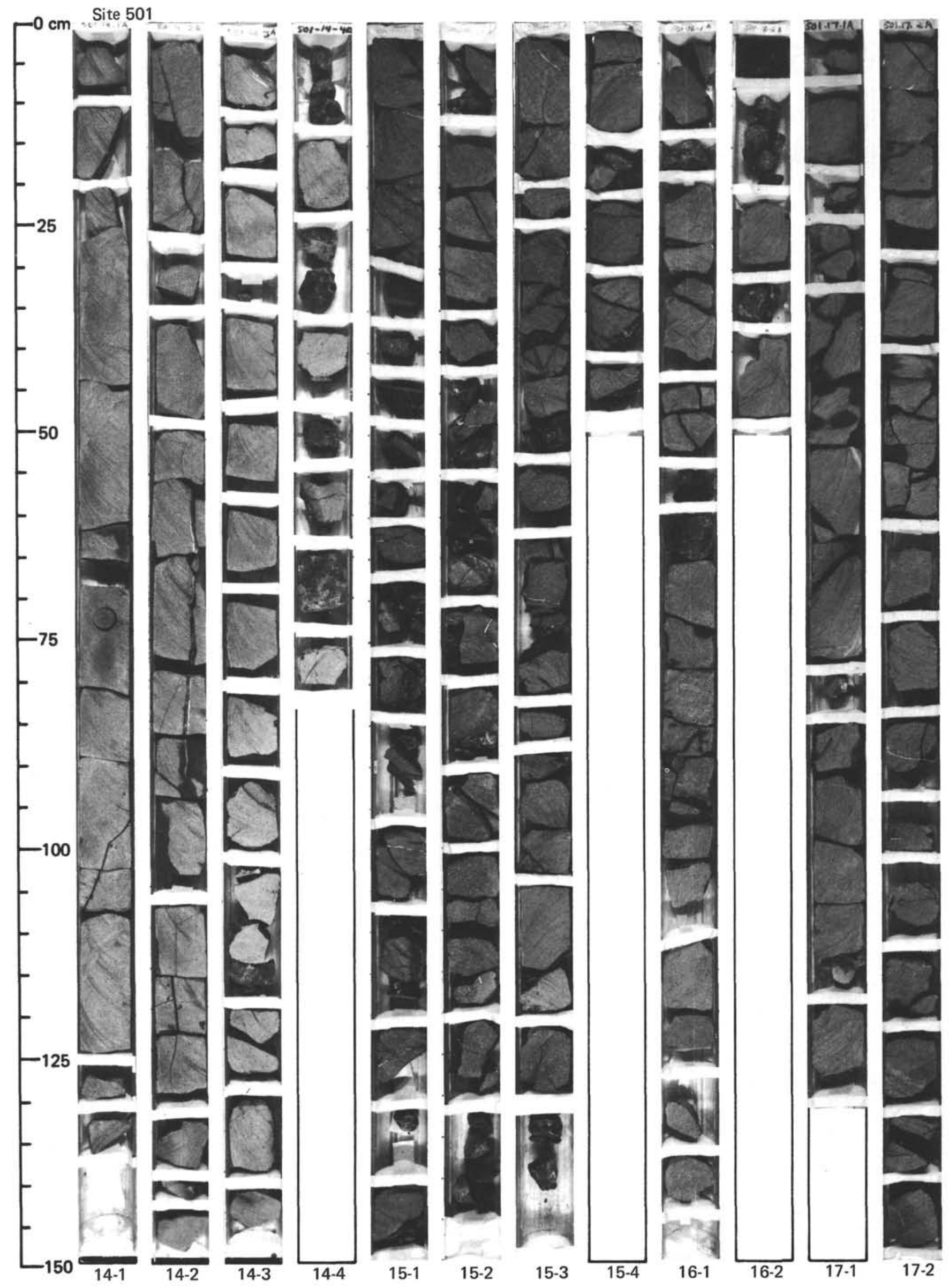




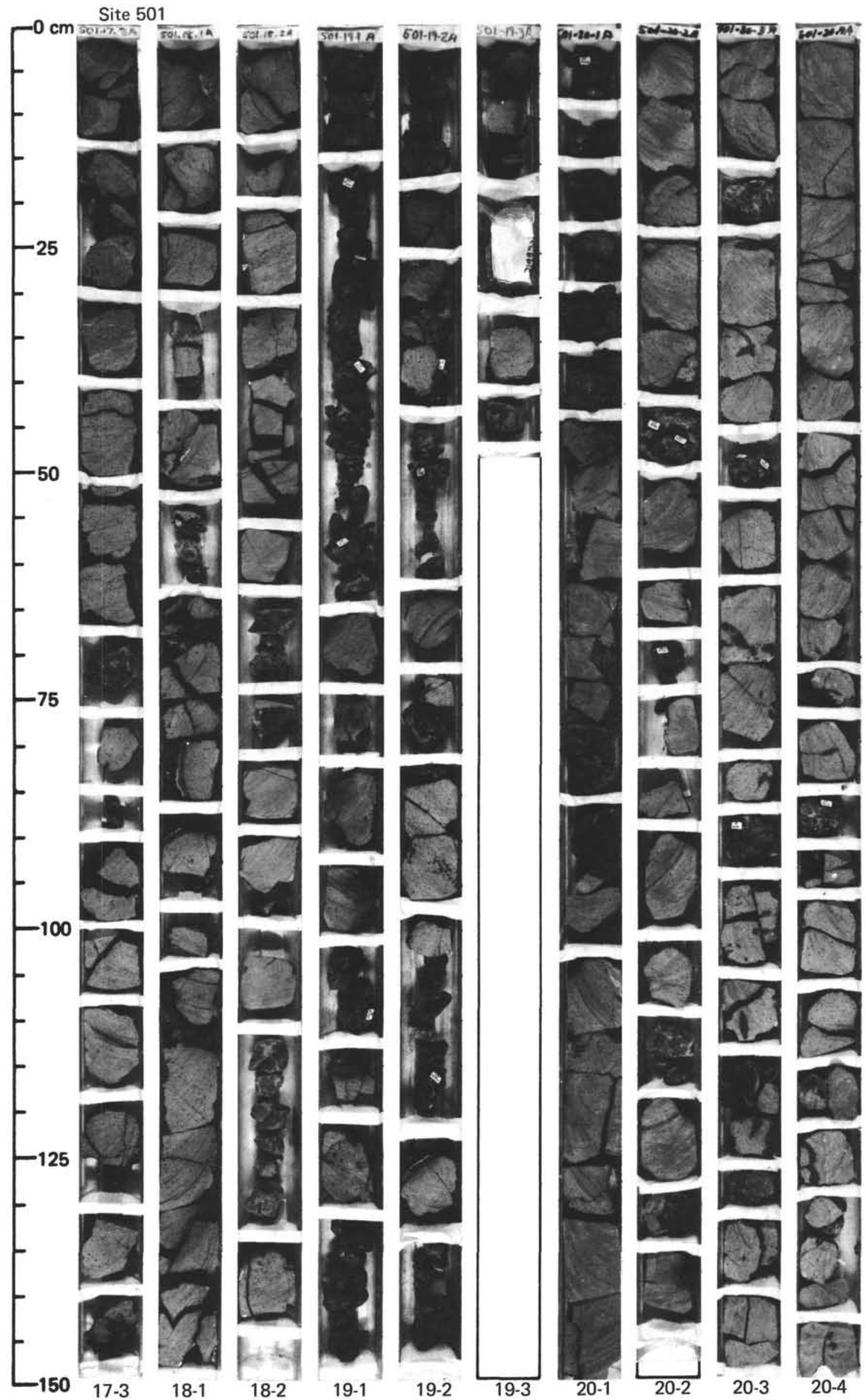




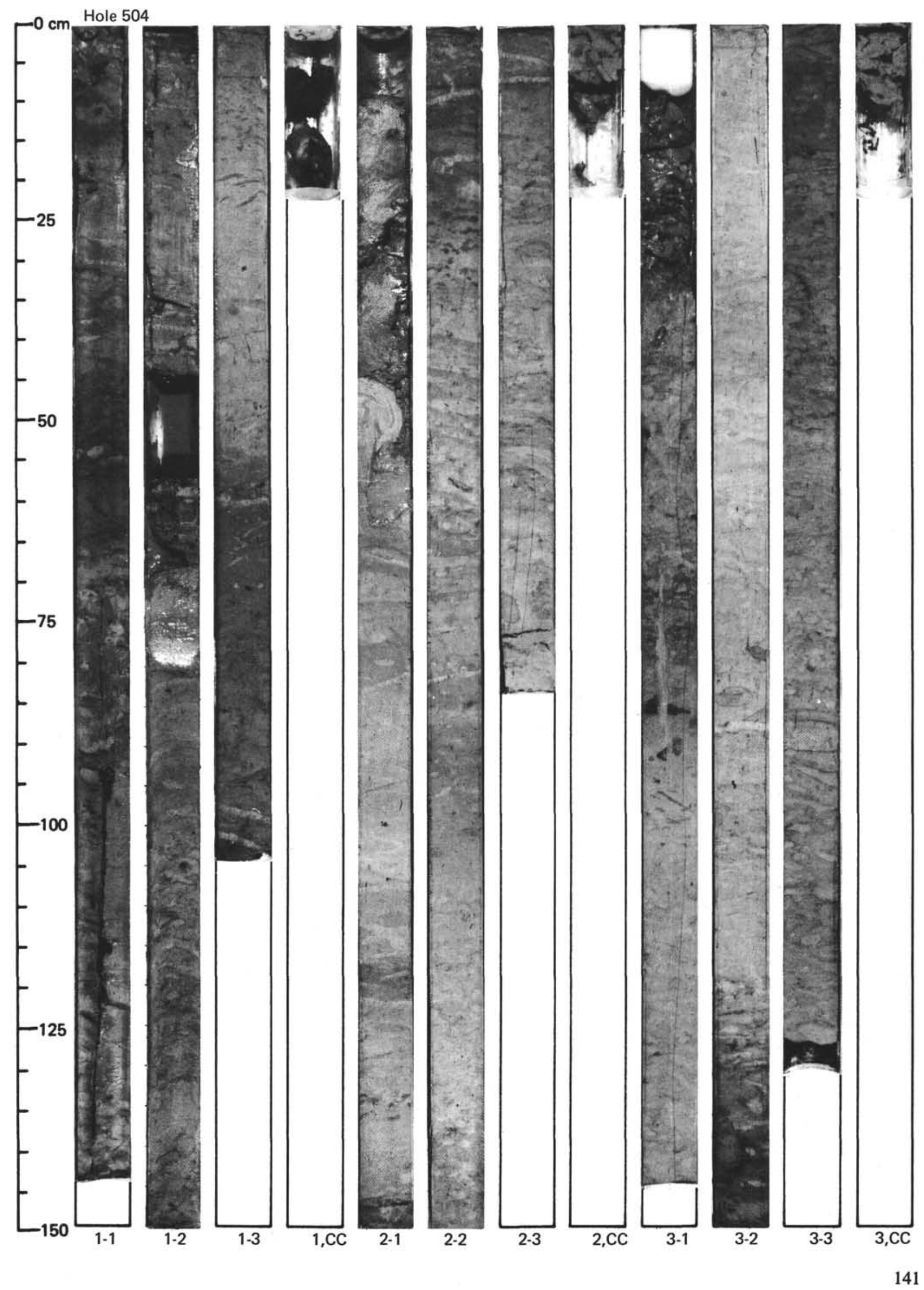




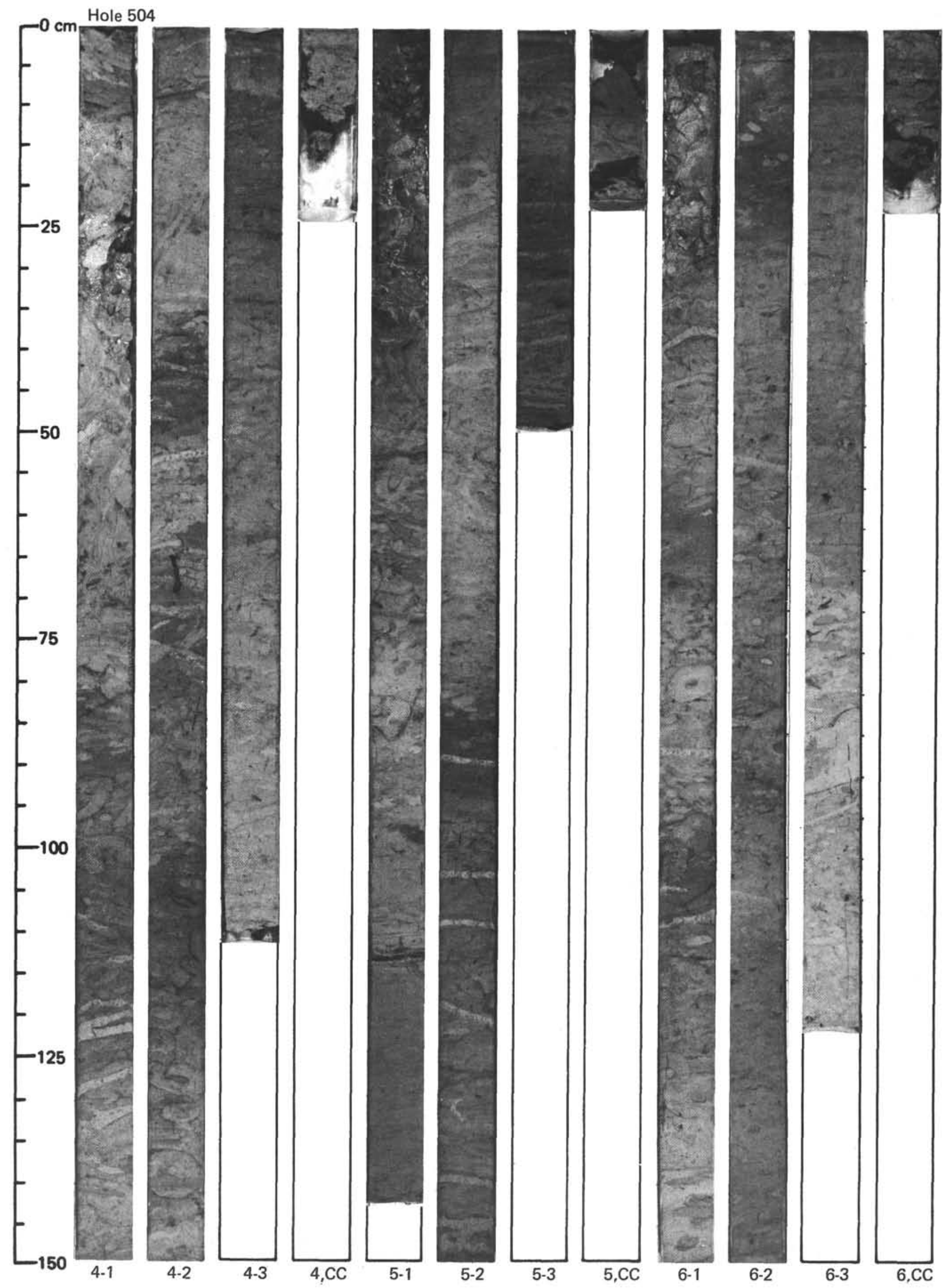




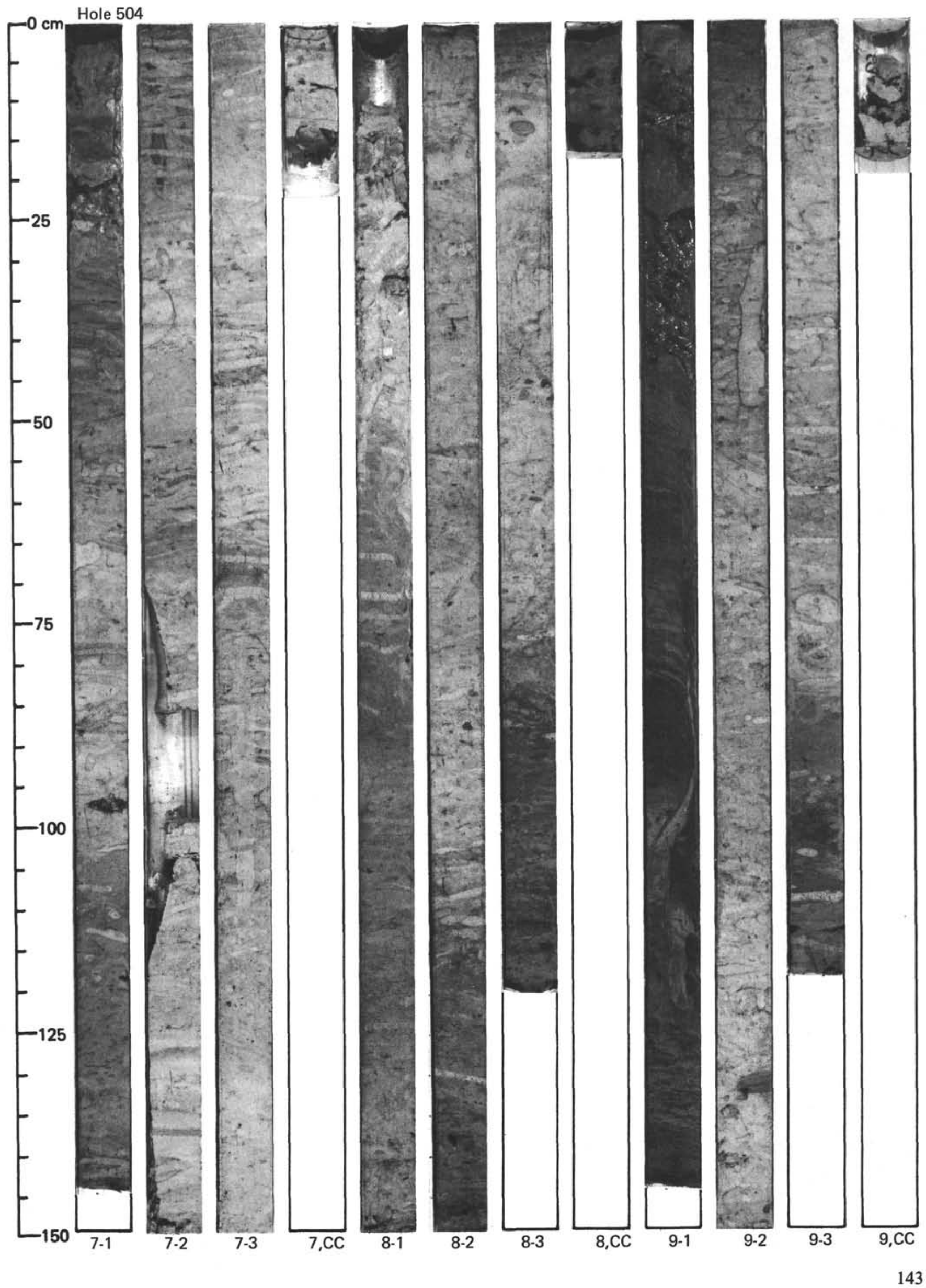




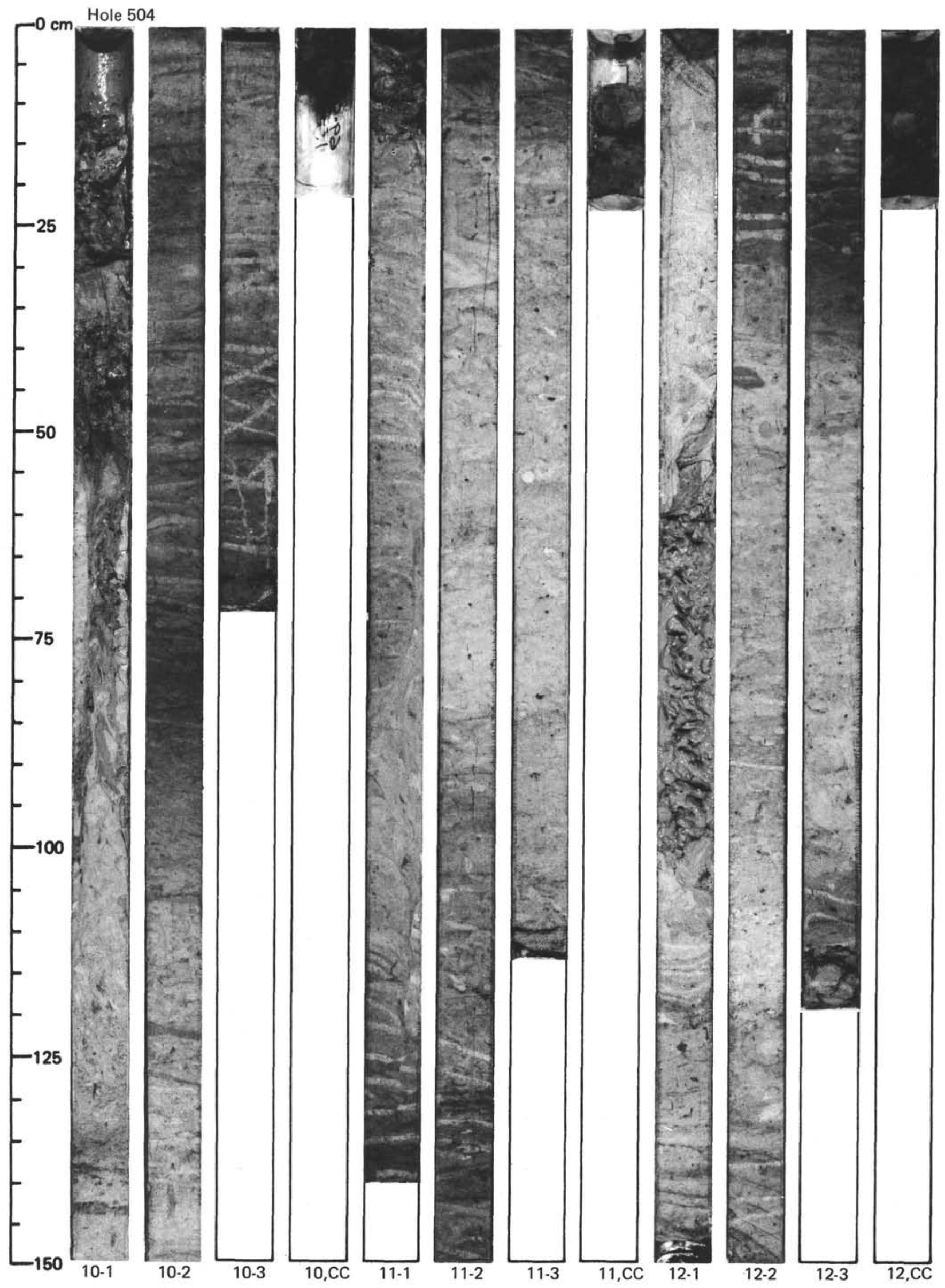




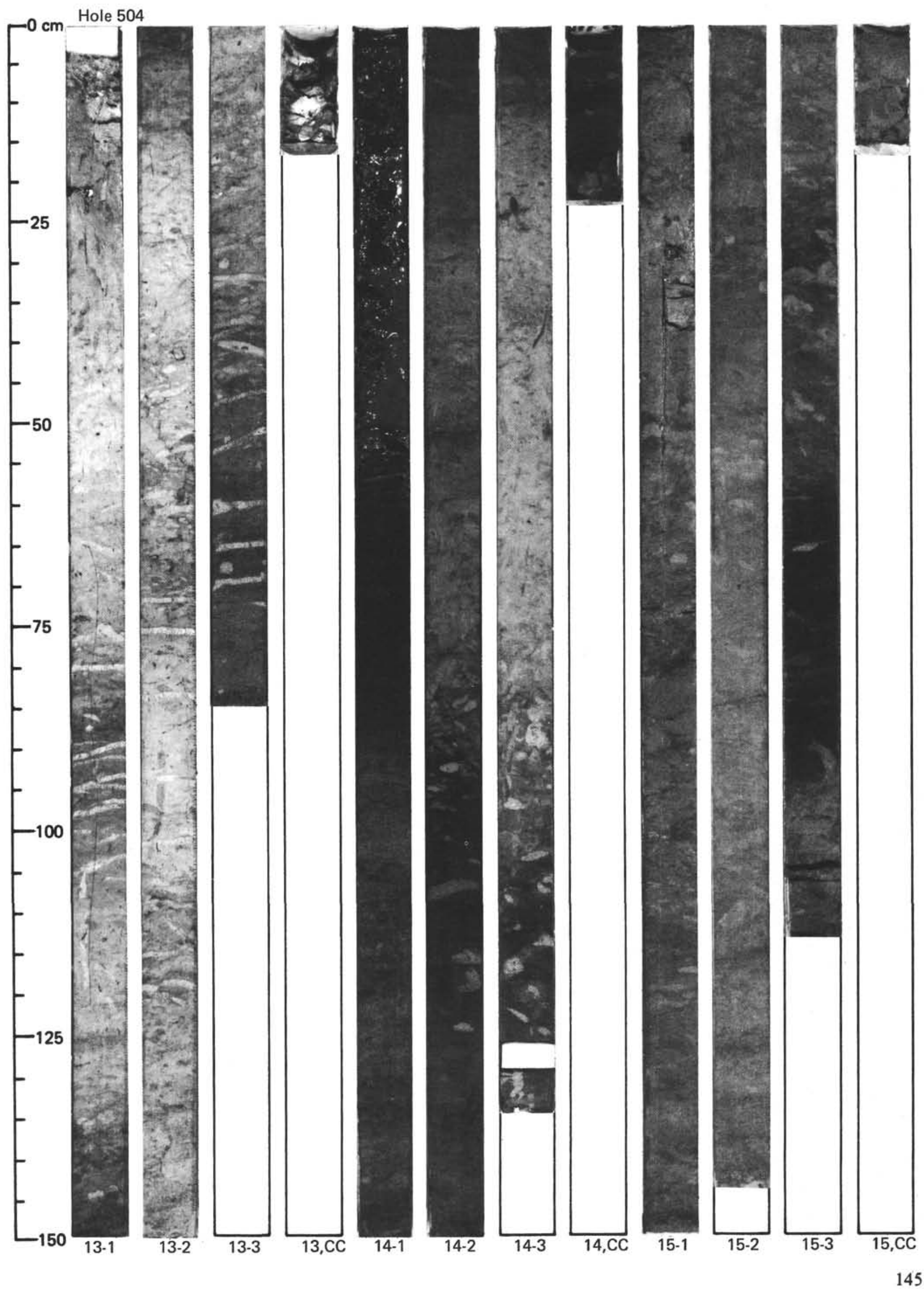




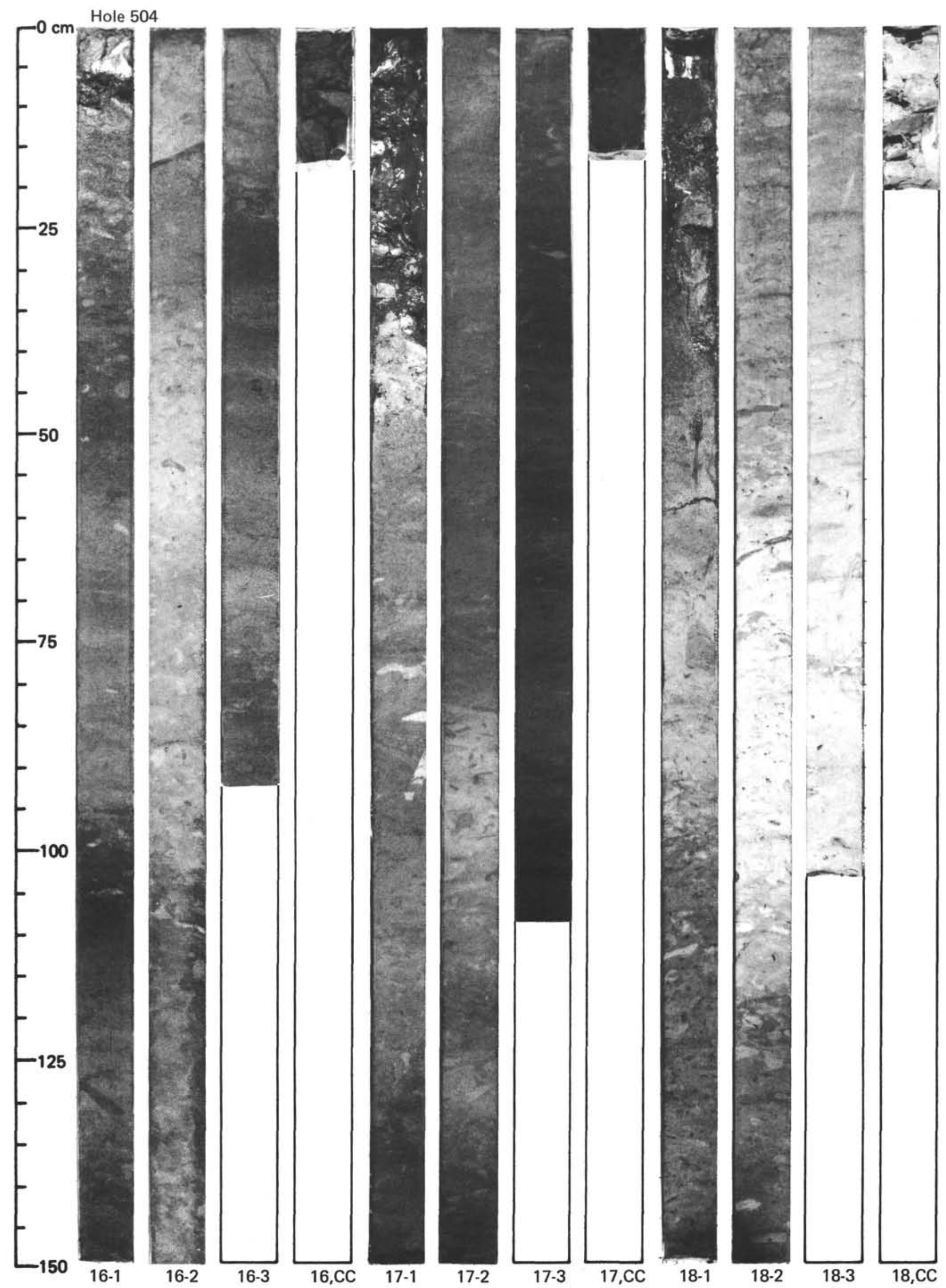




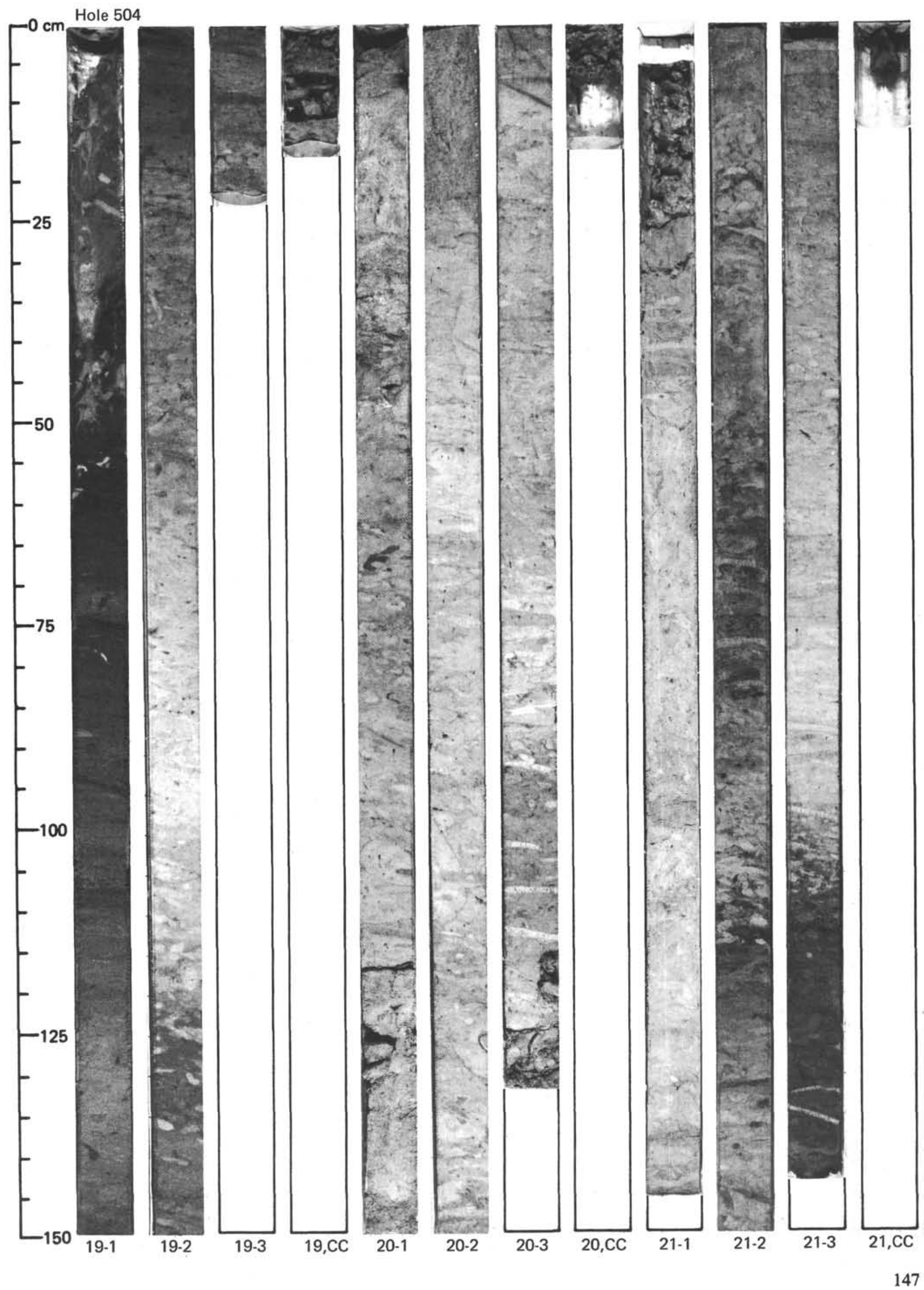




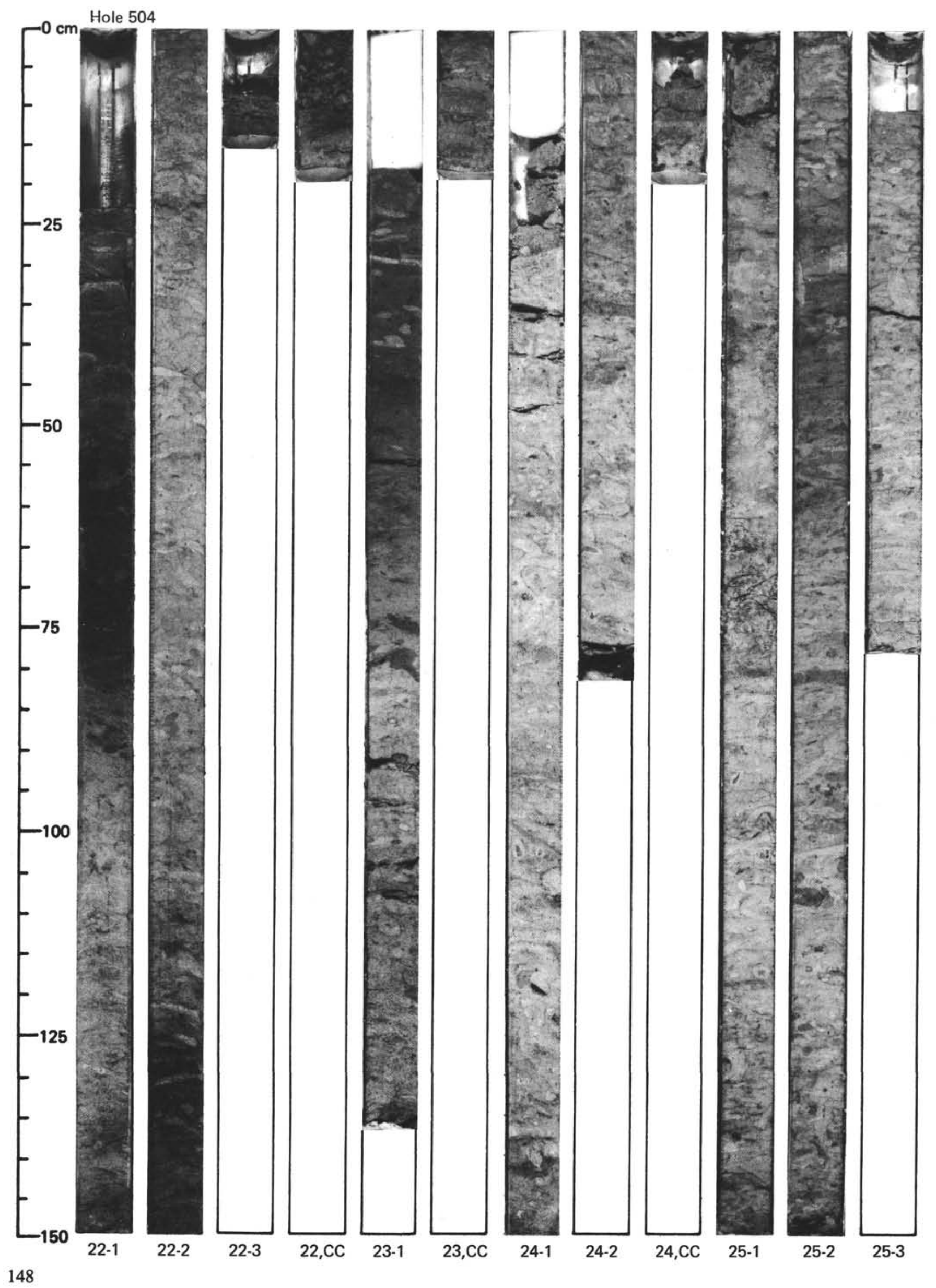




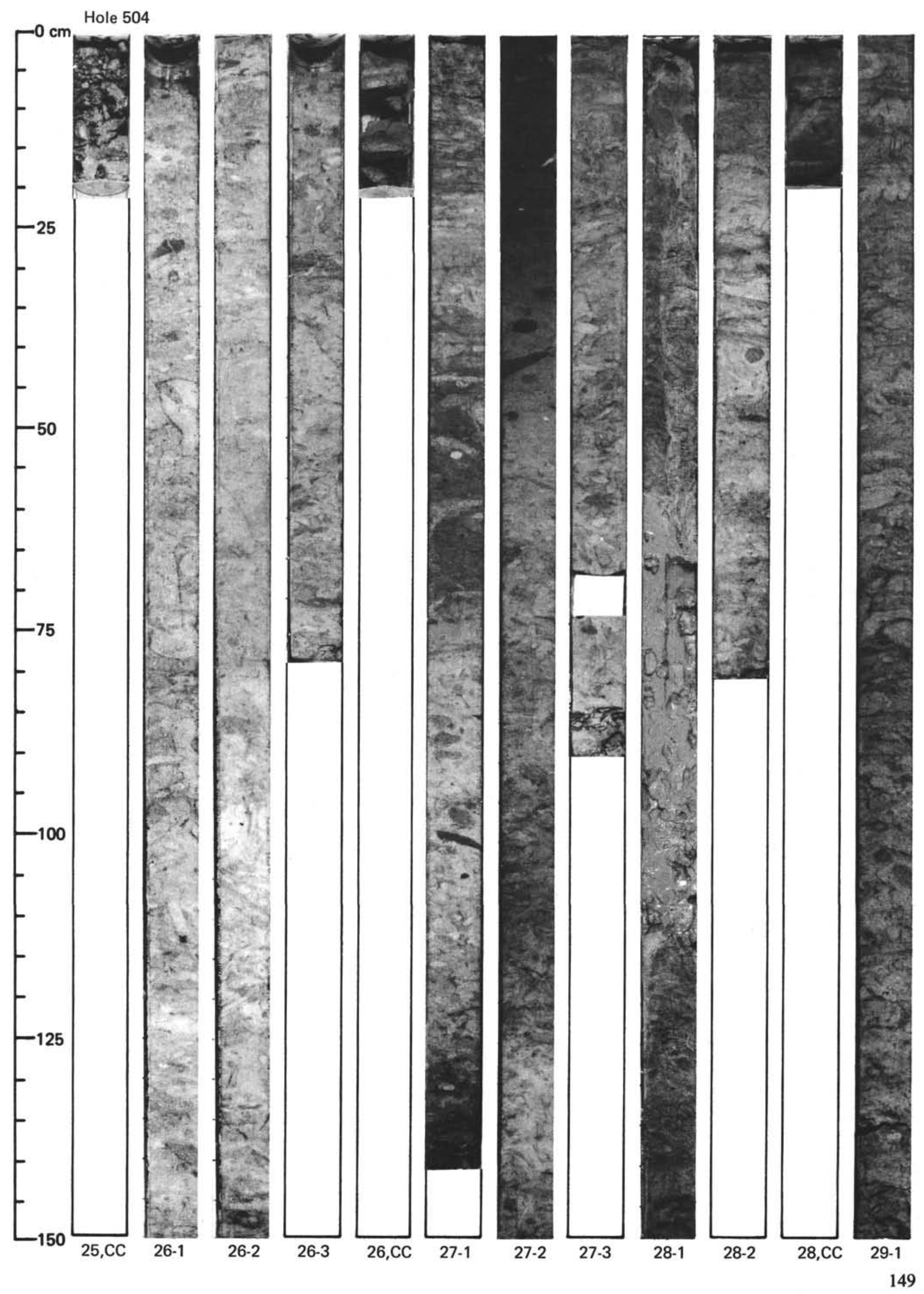




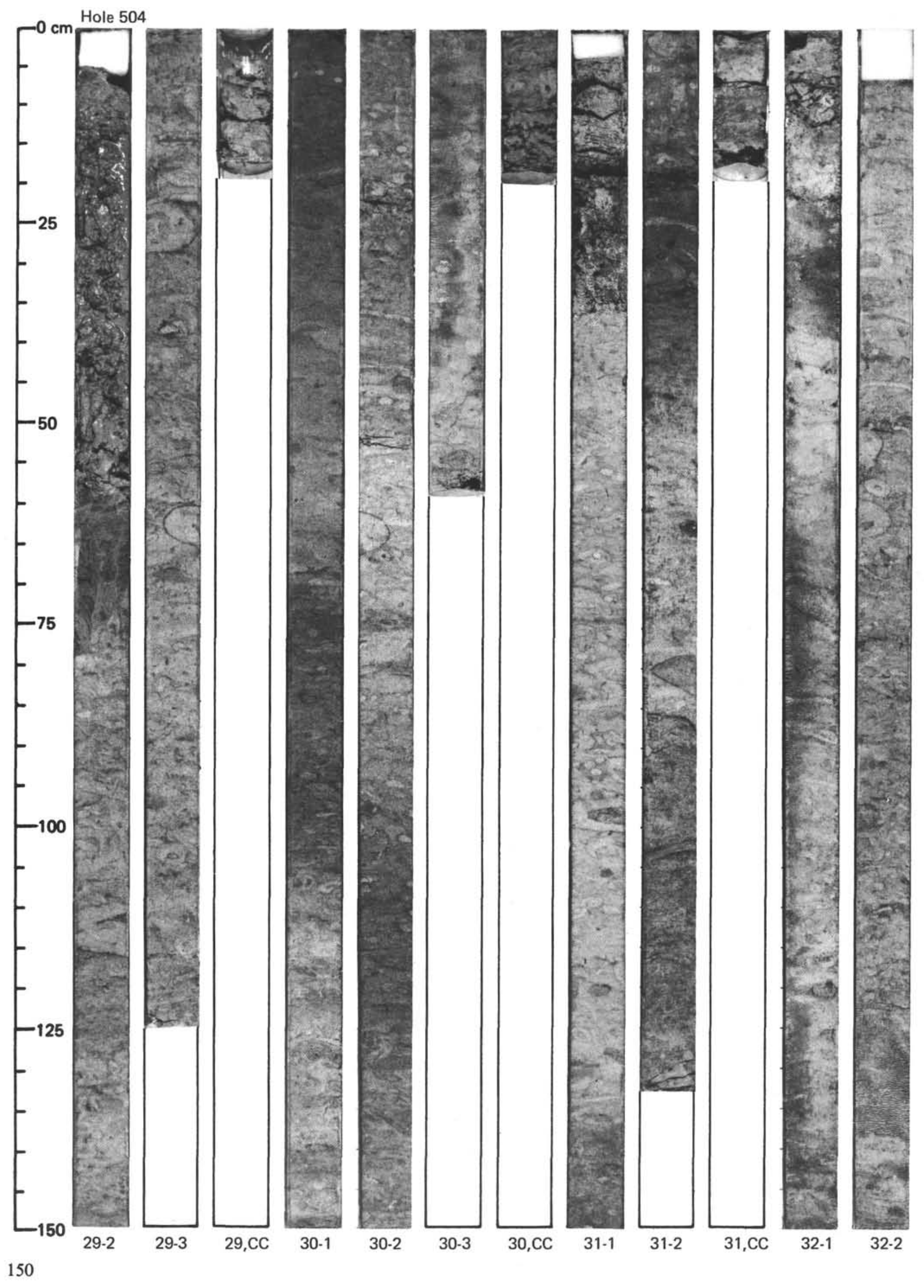




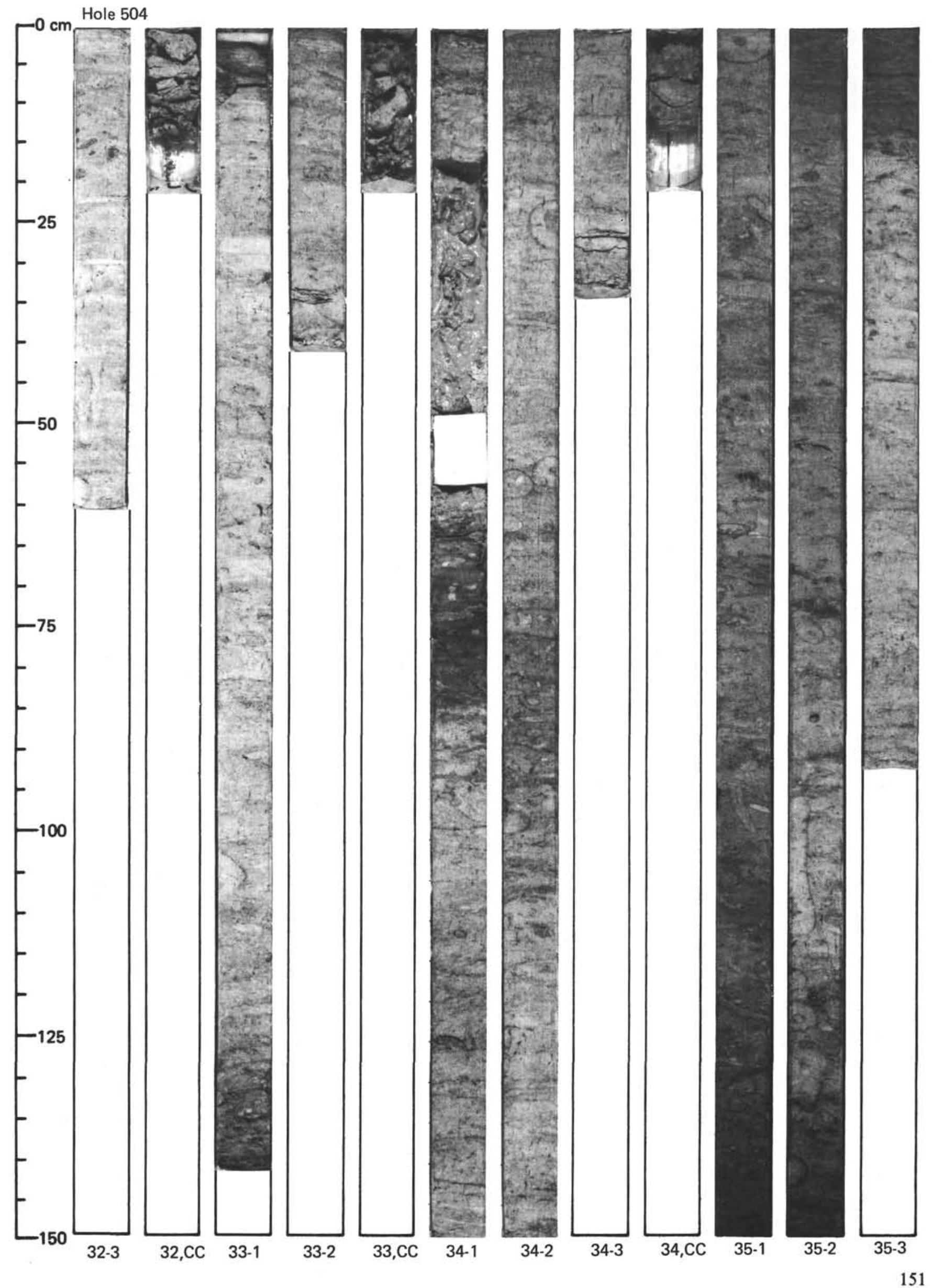




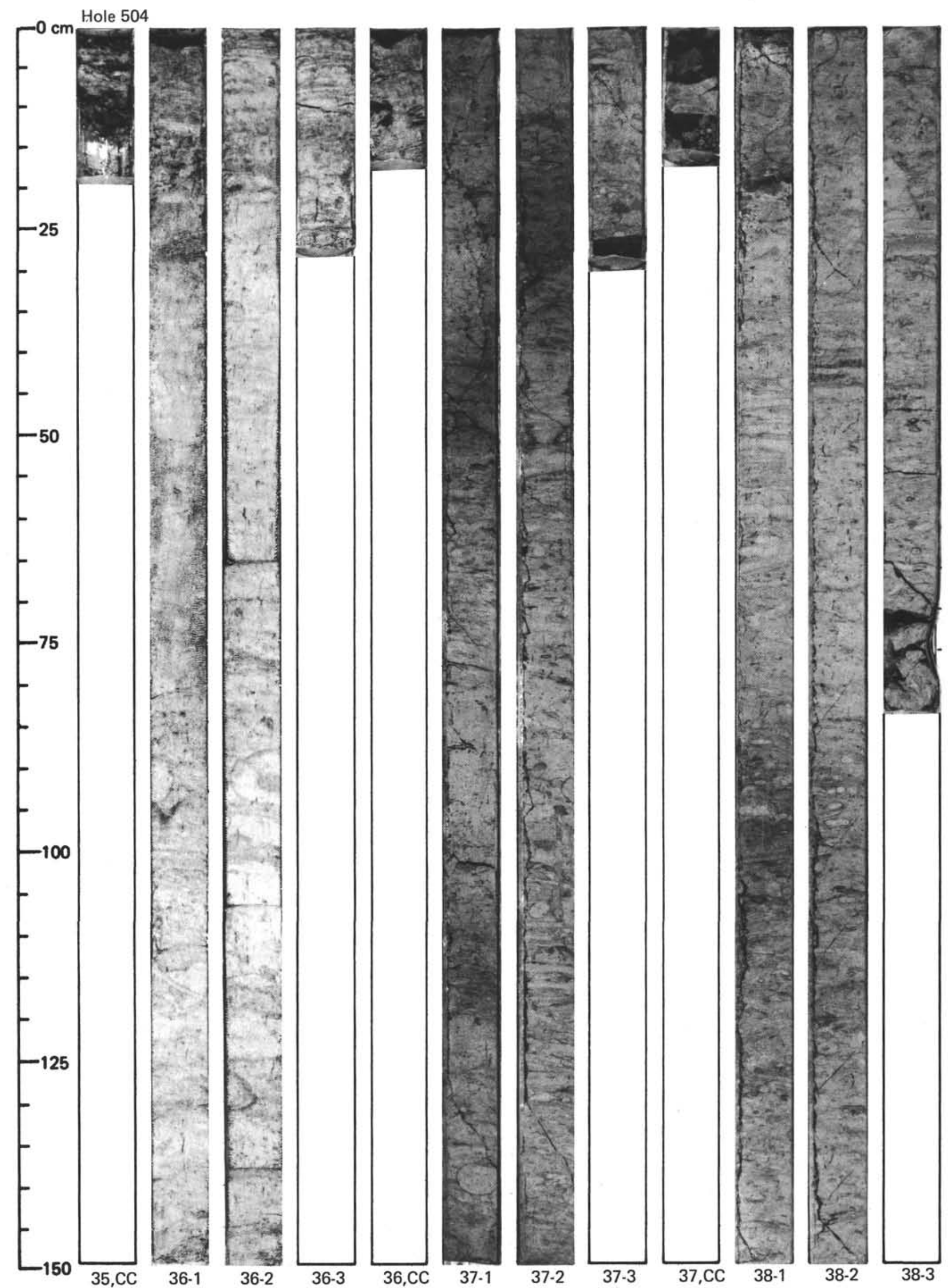




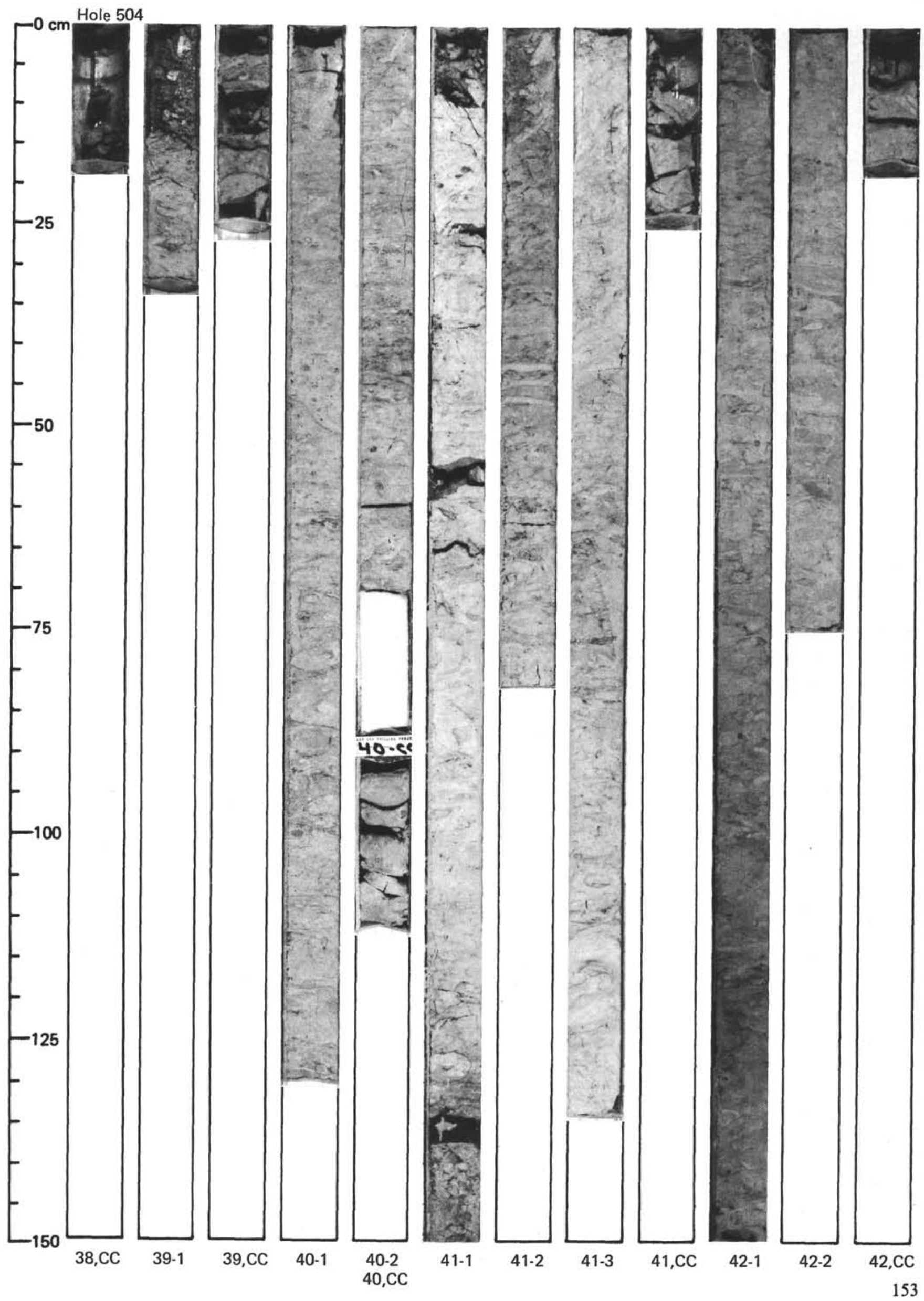




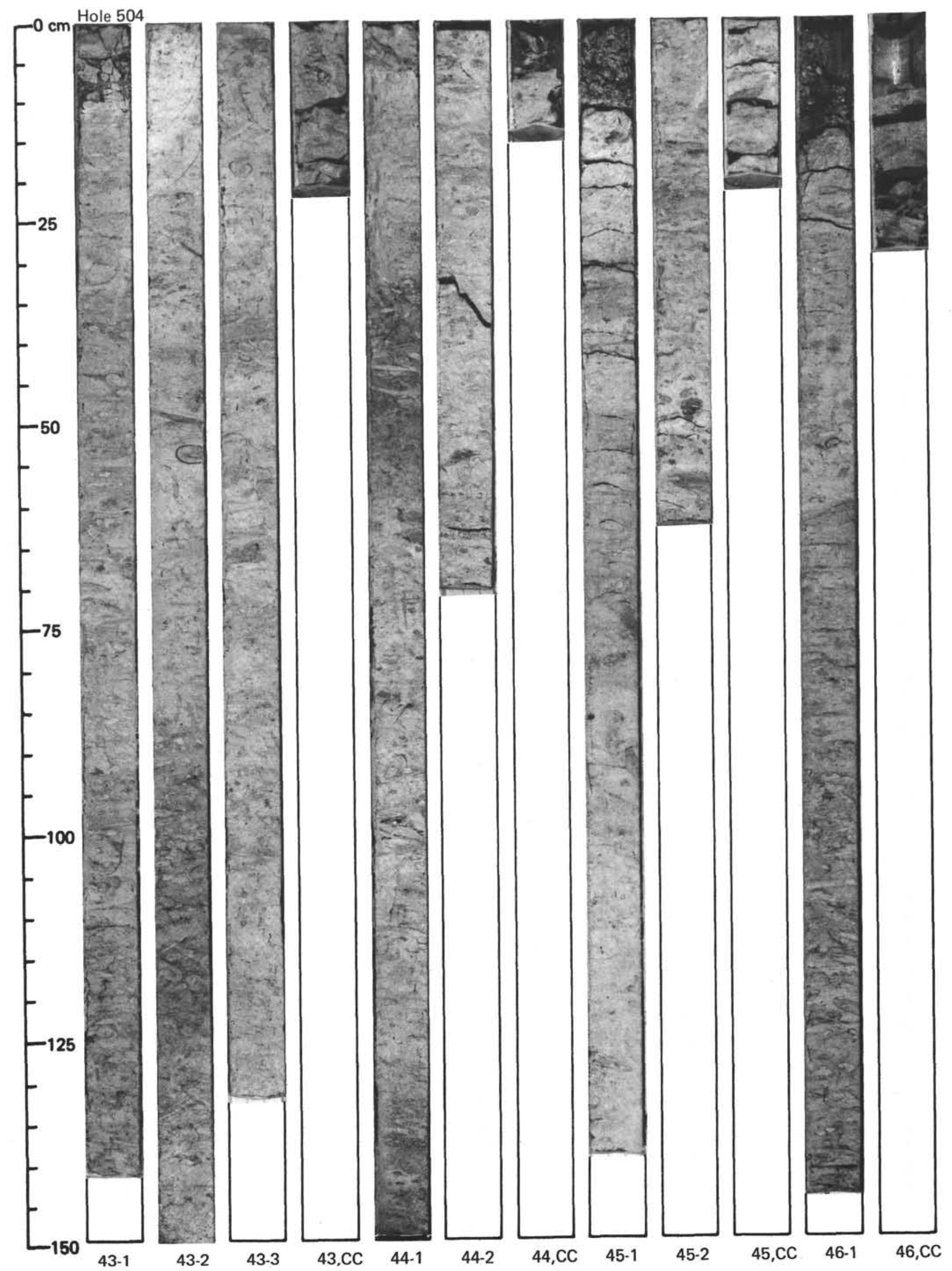




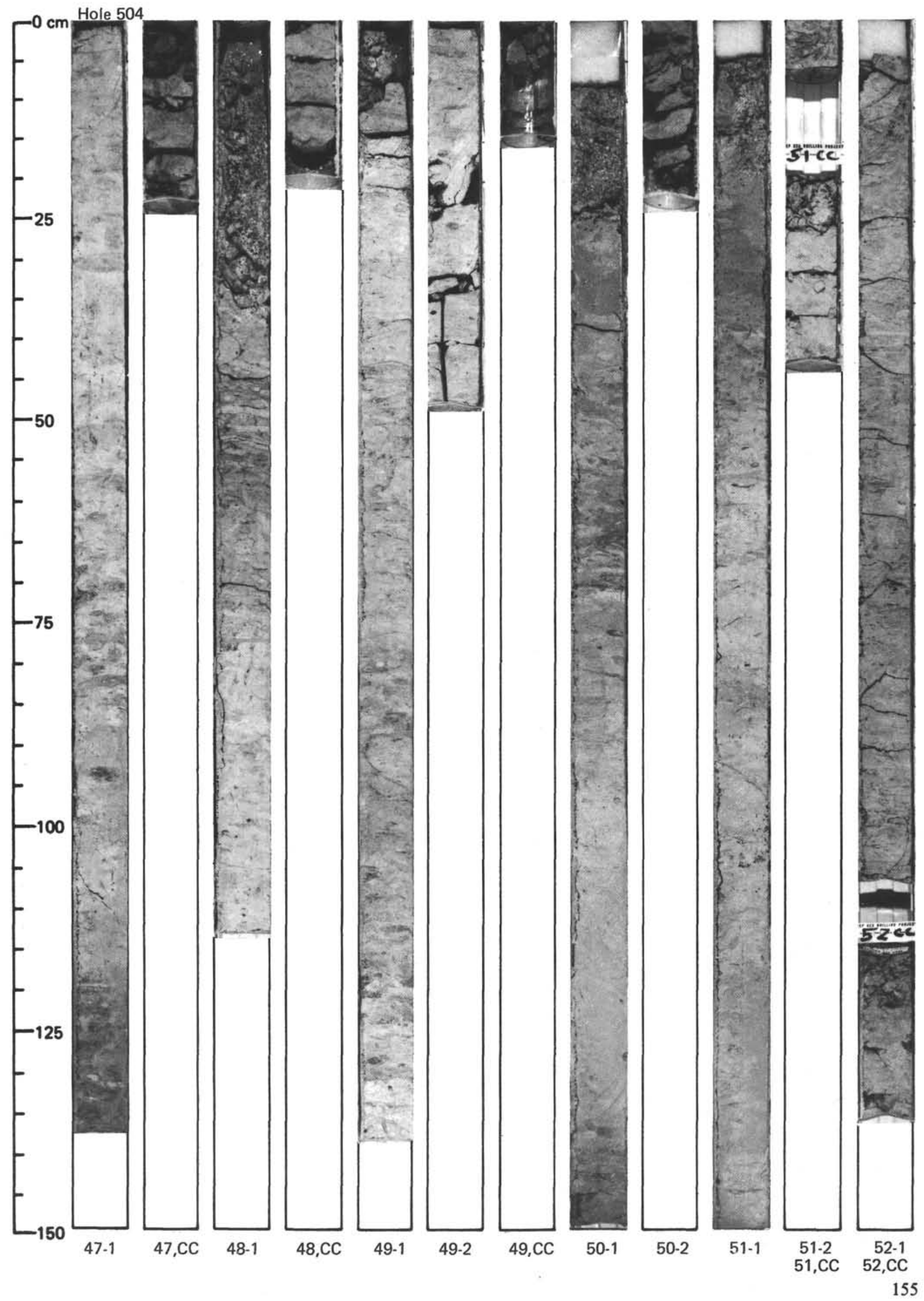


SITES 501 AND 504

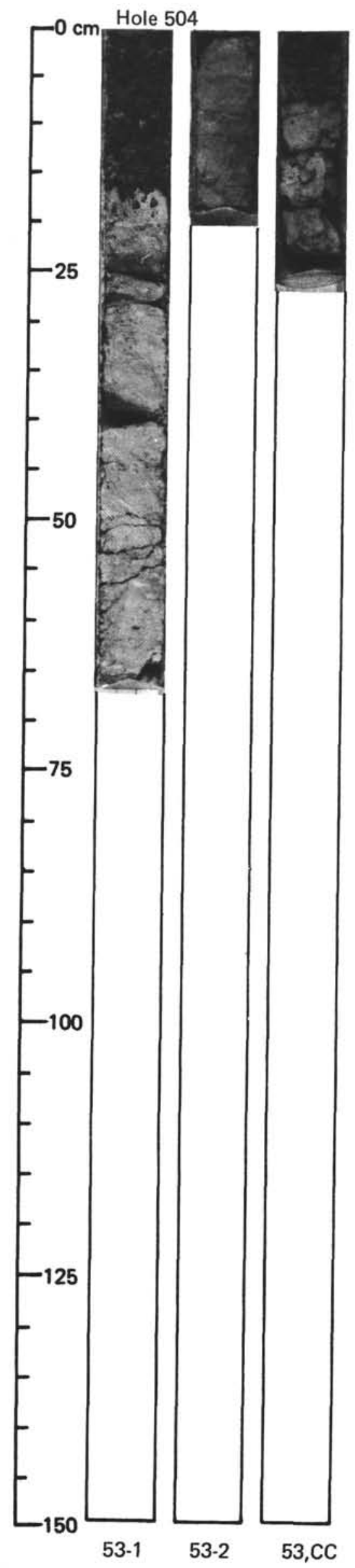




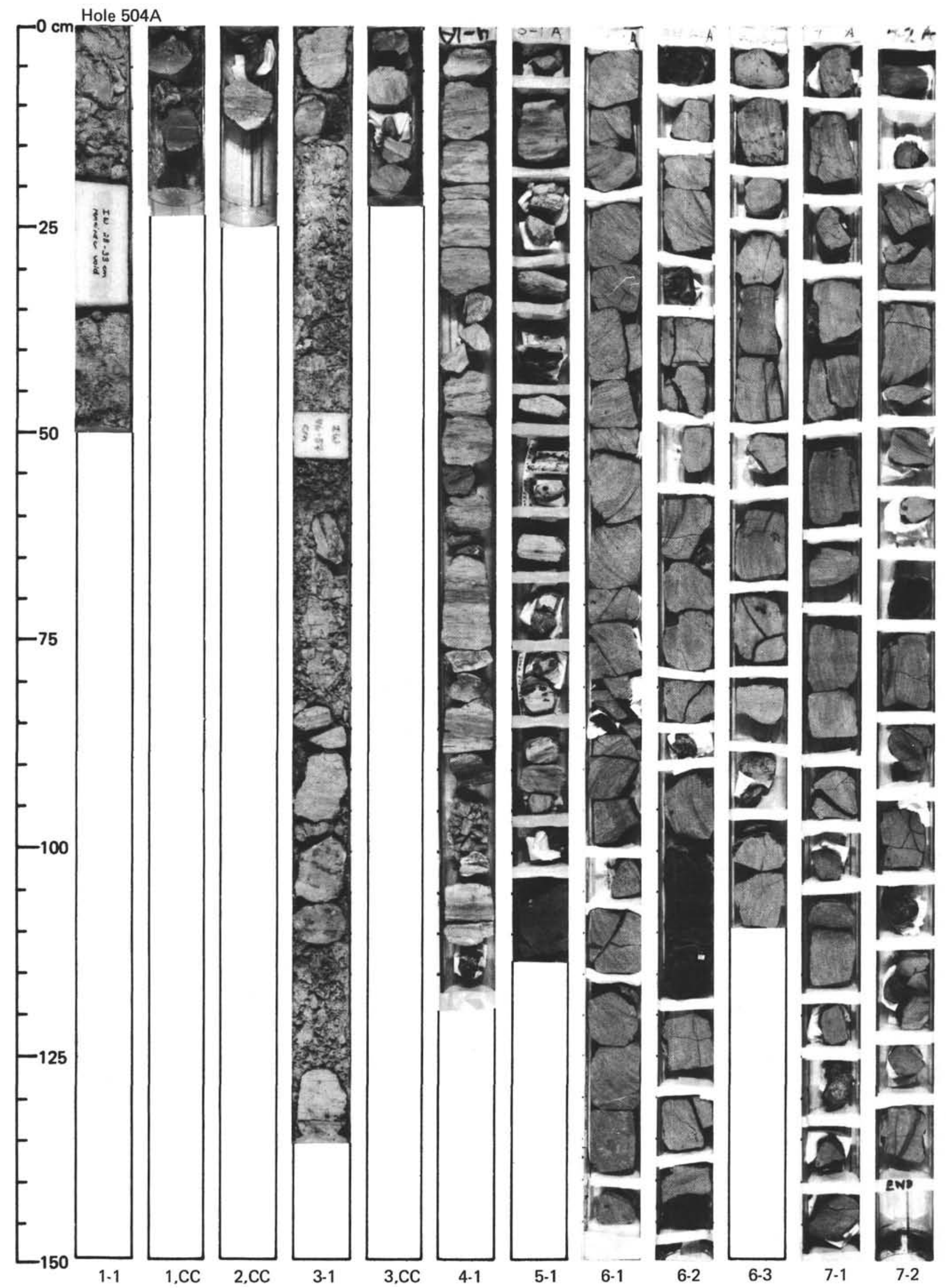




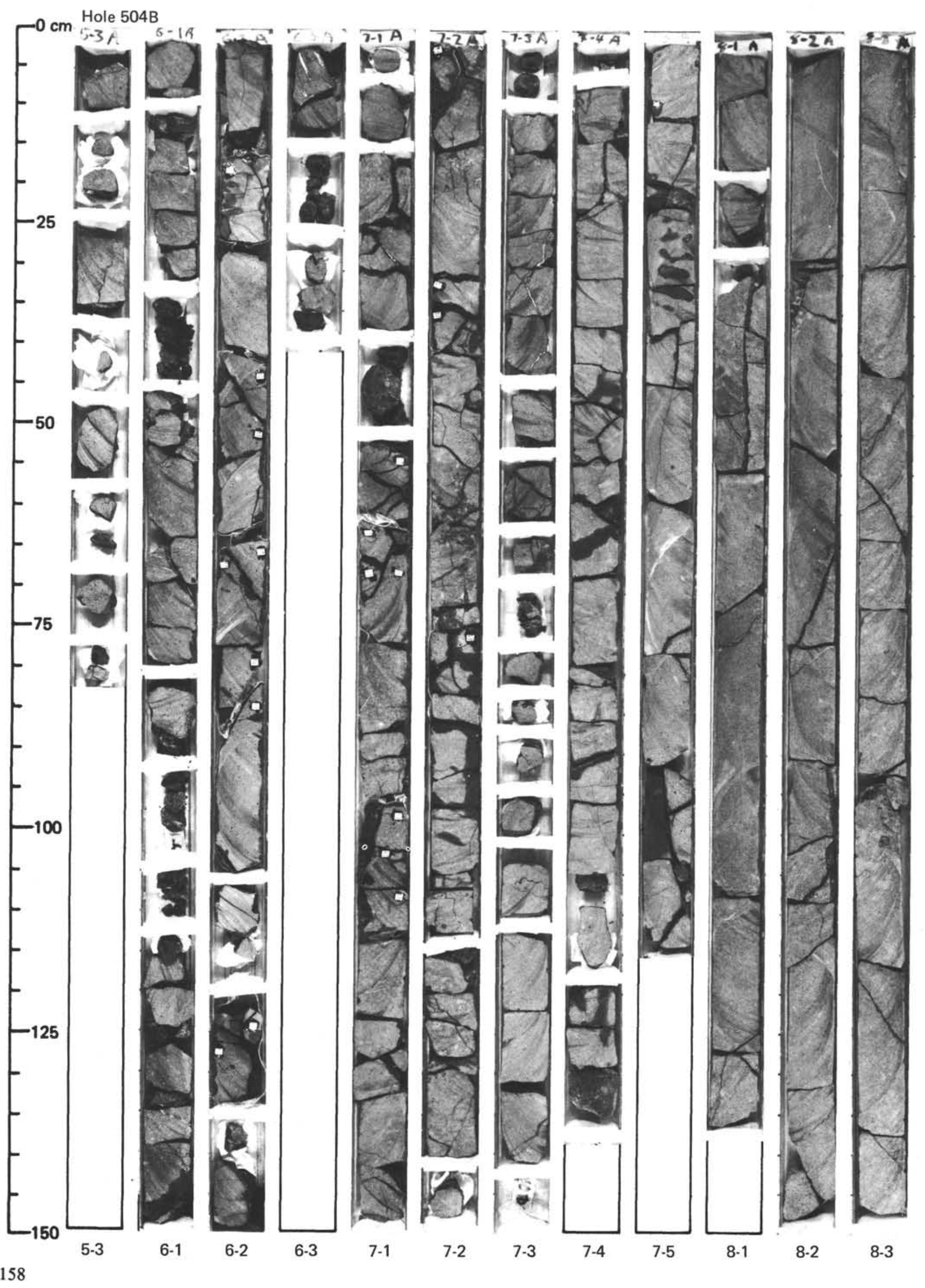




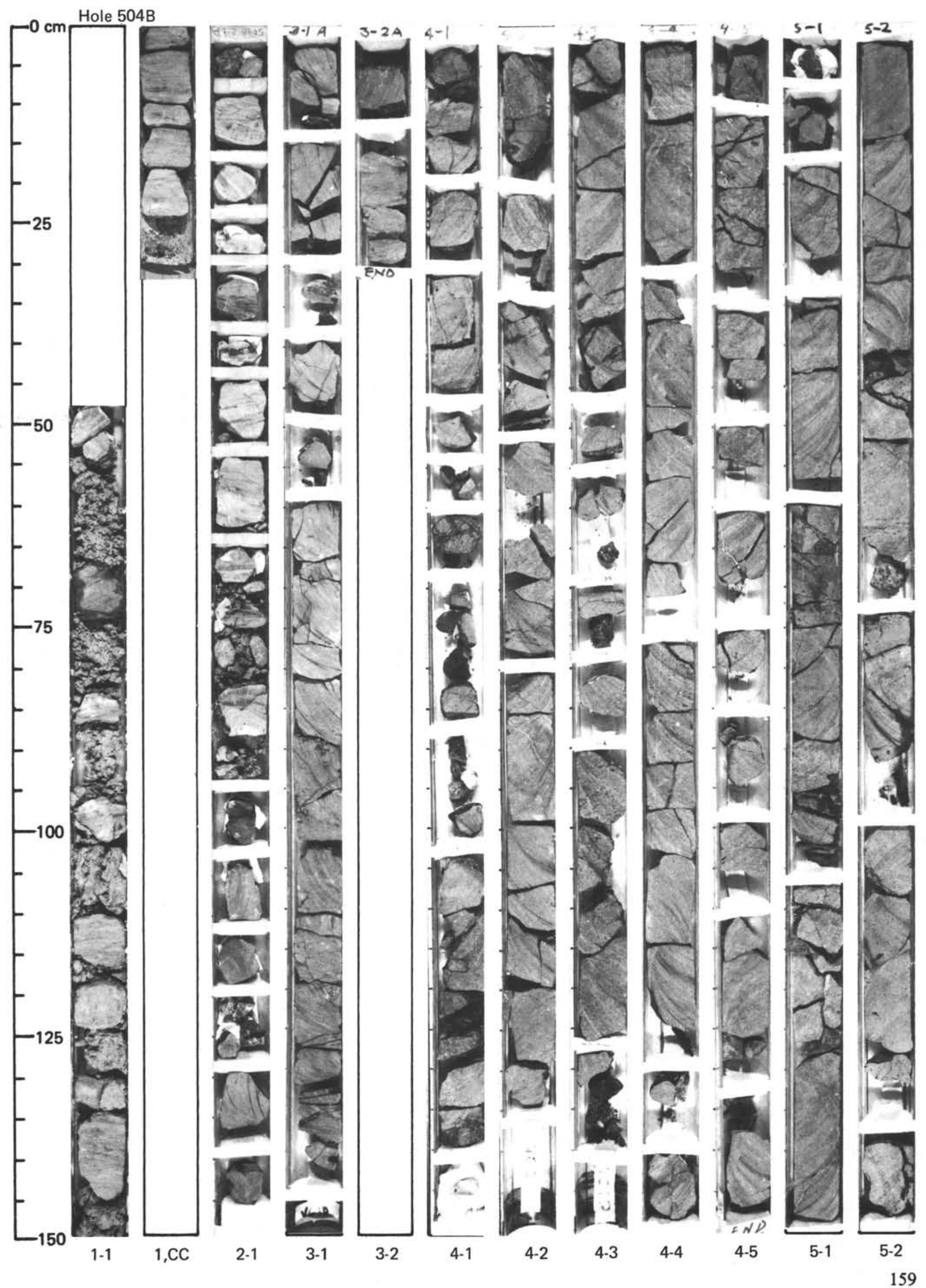




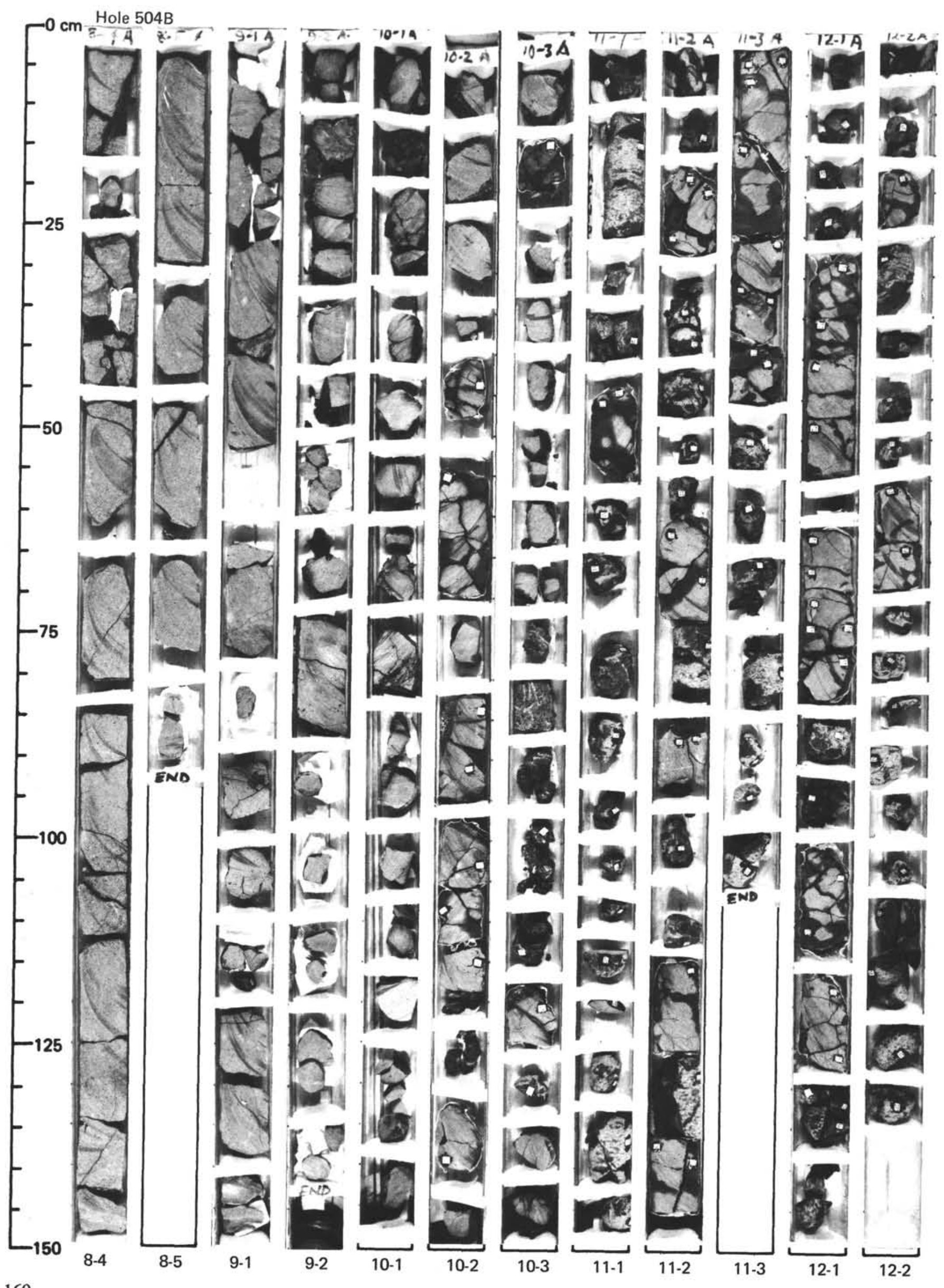




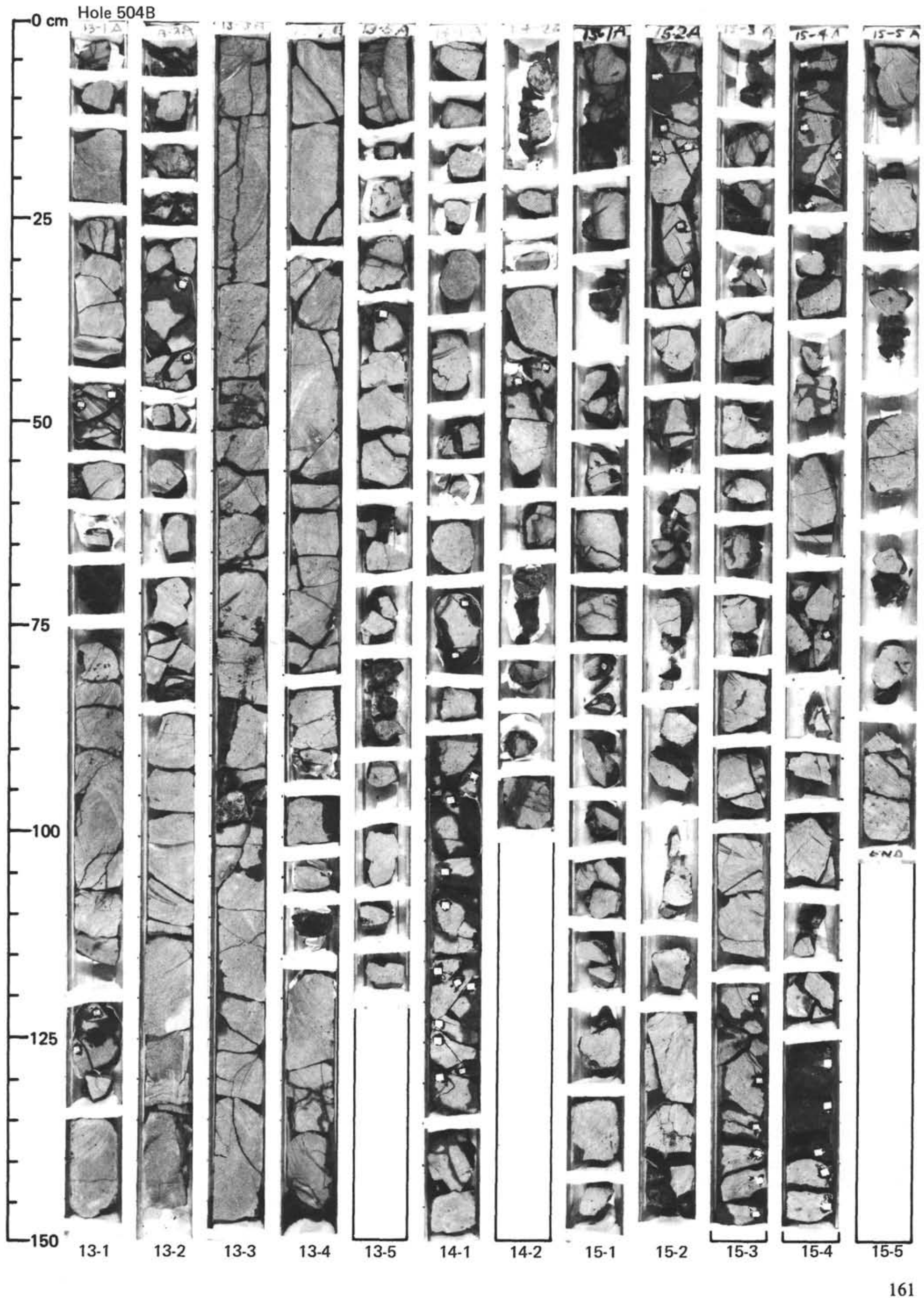




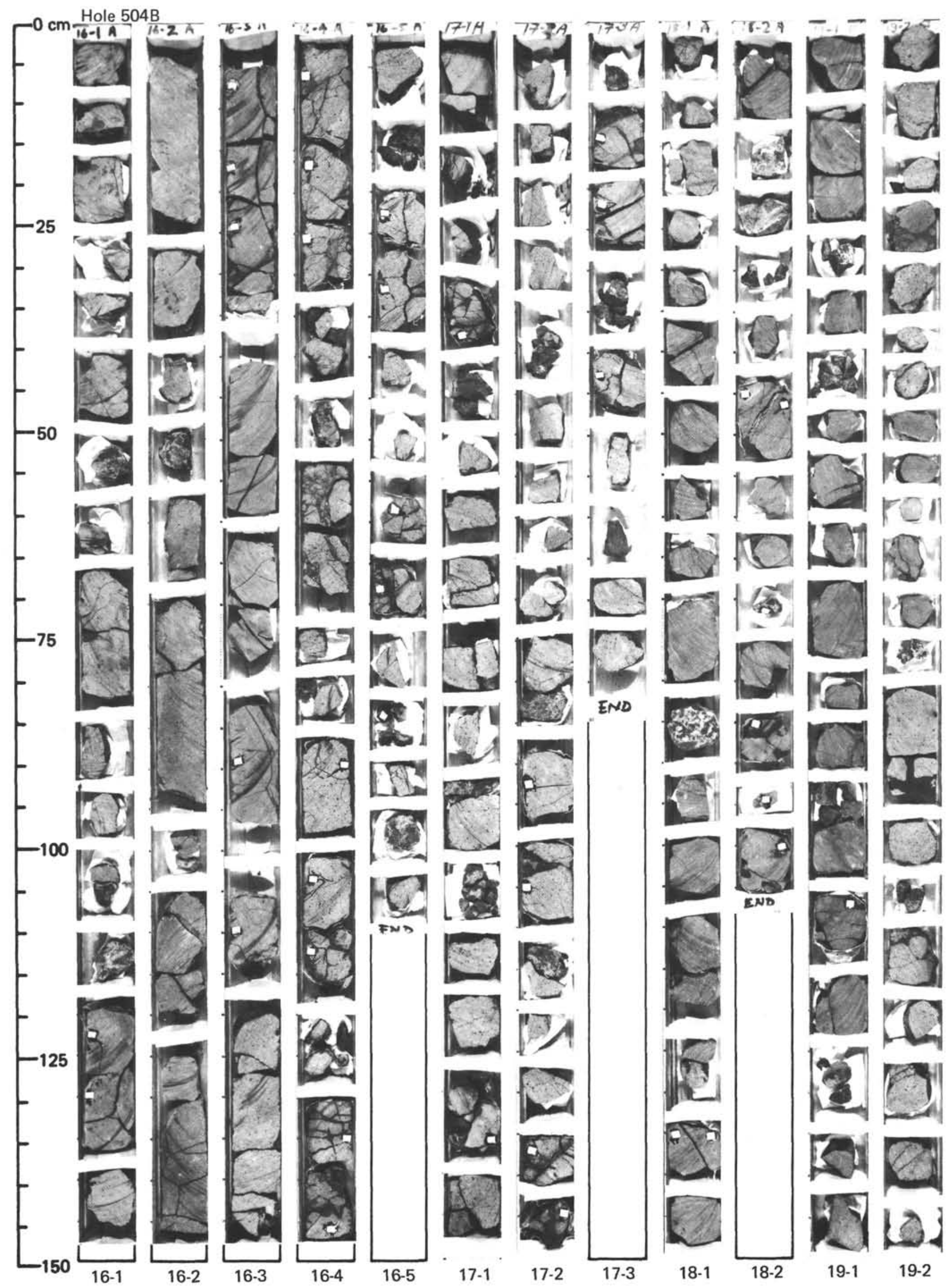




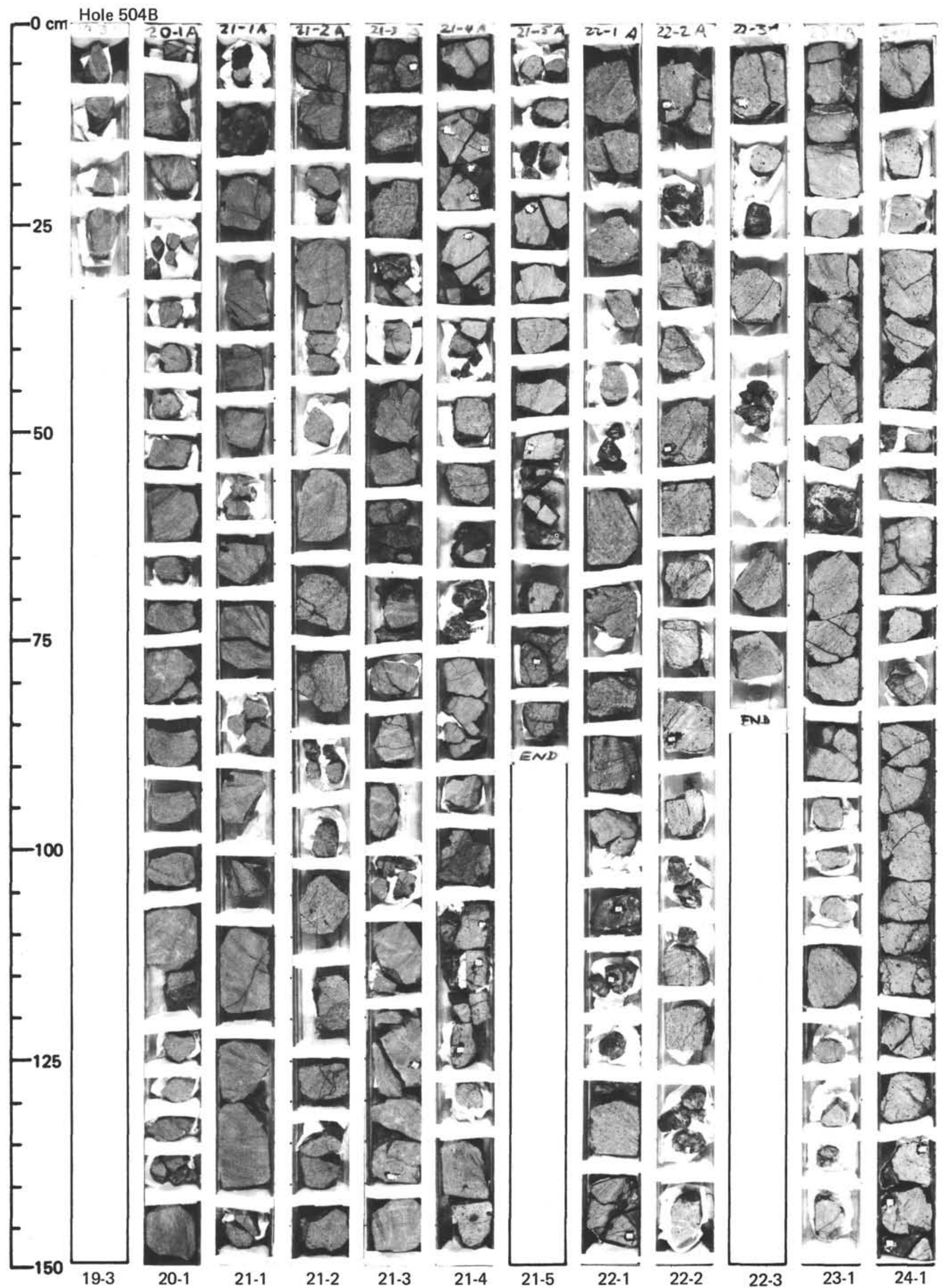




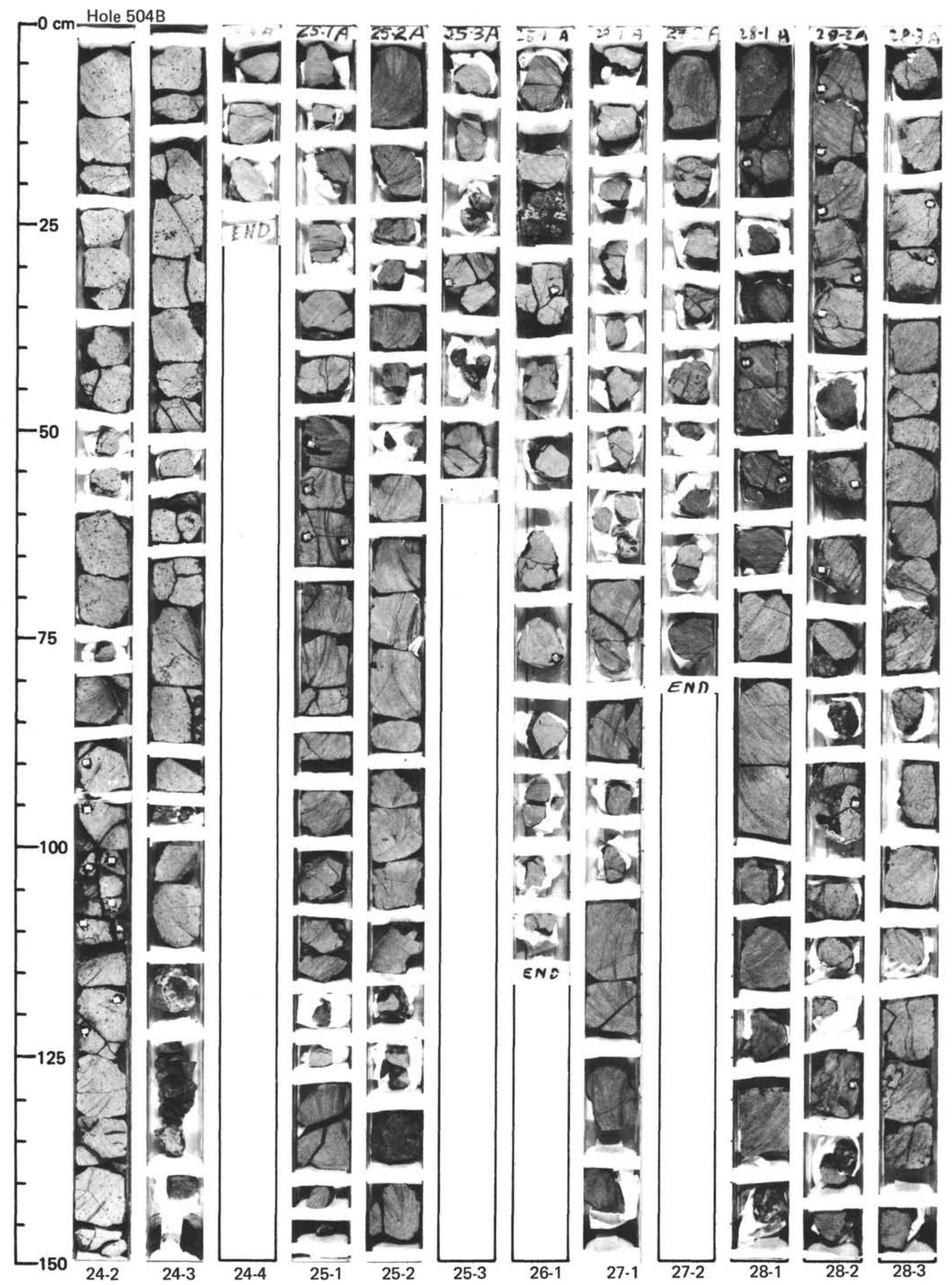




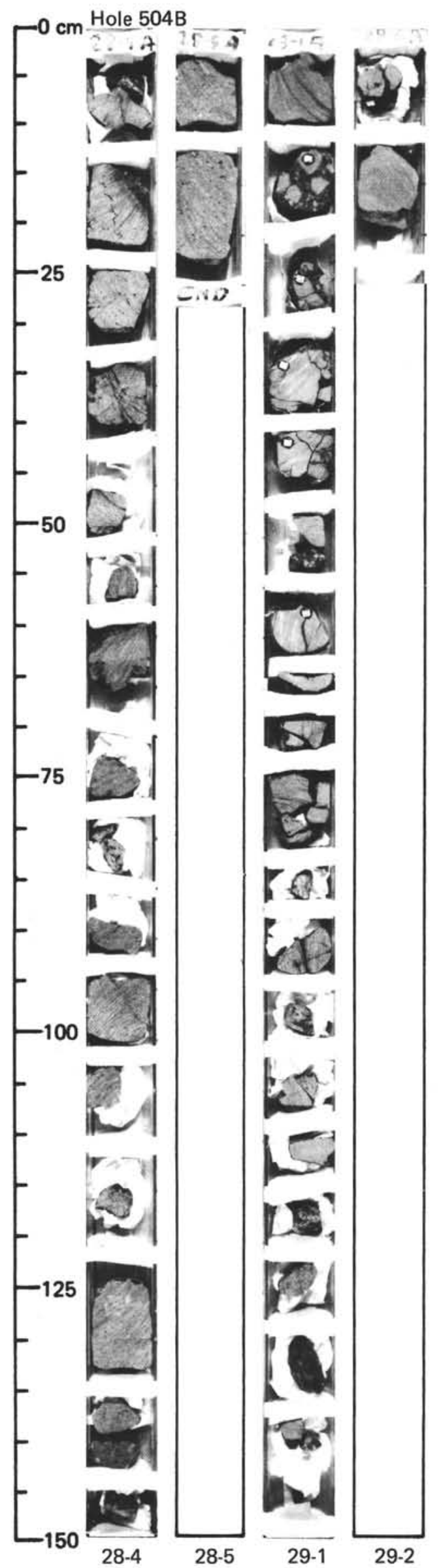




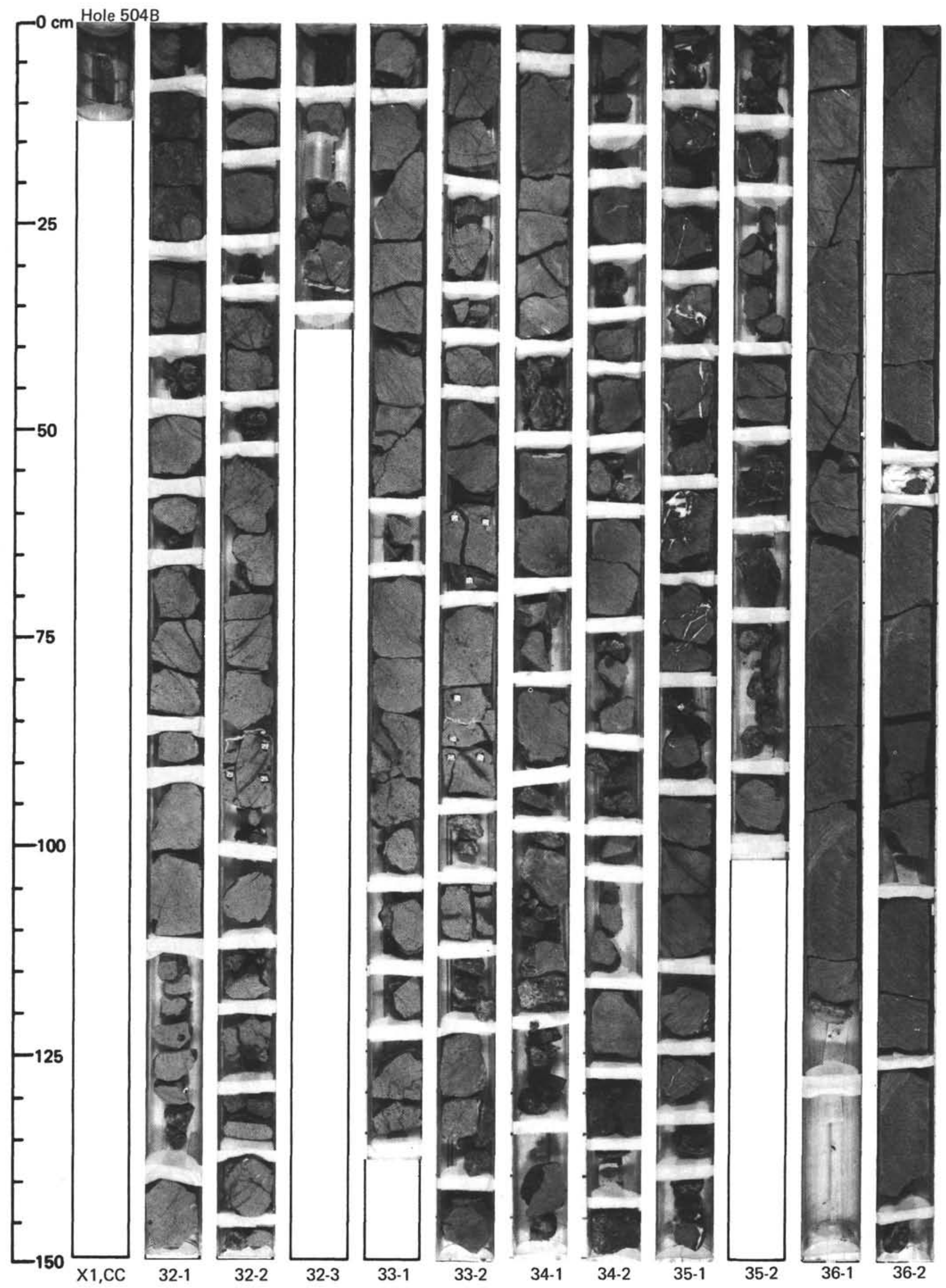




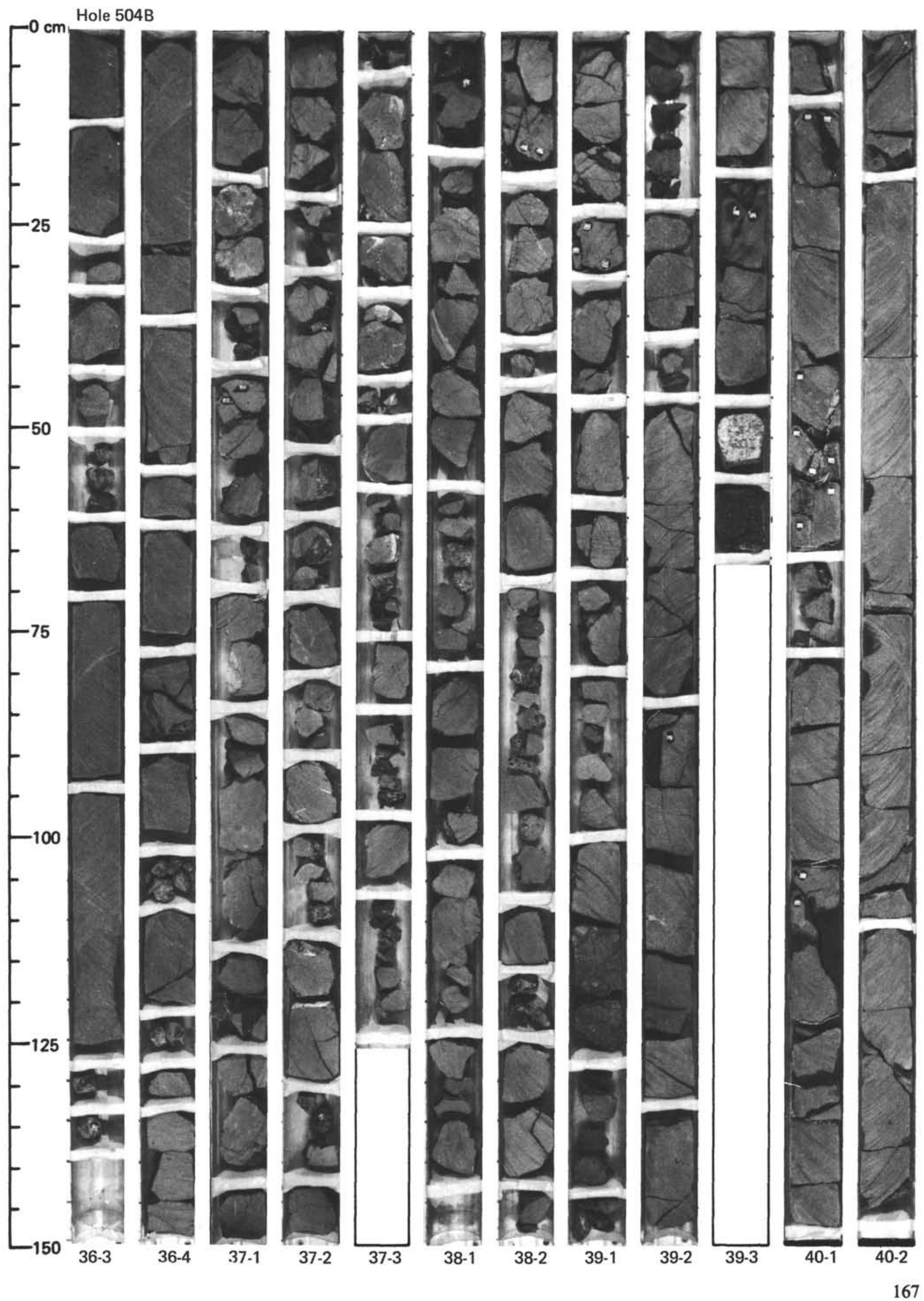


SITES 501 AND 504

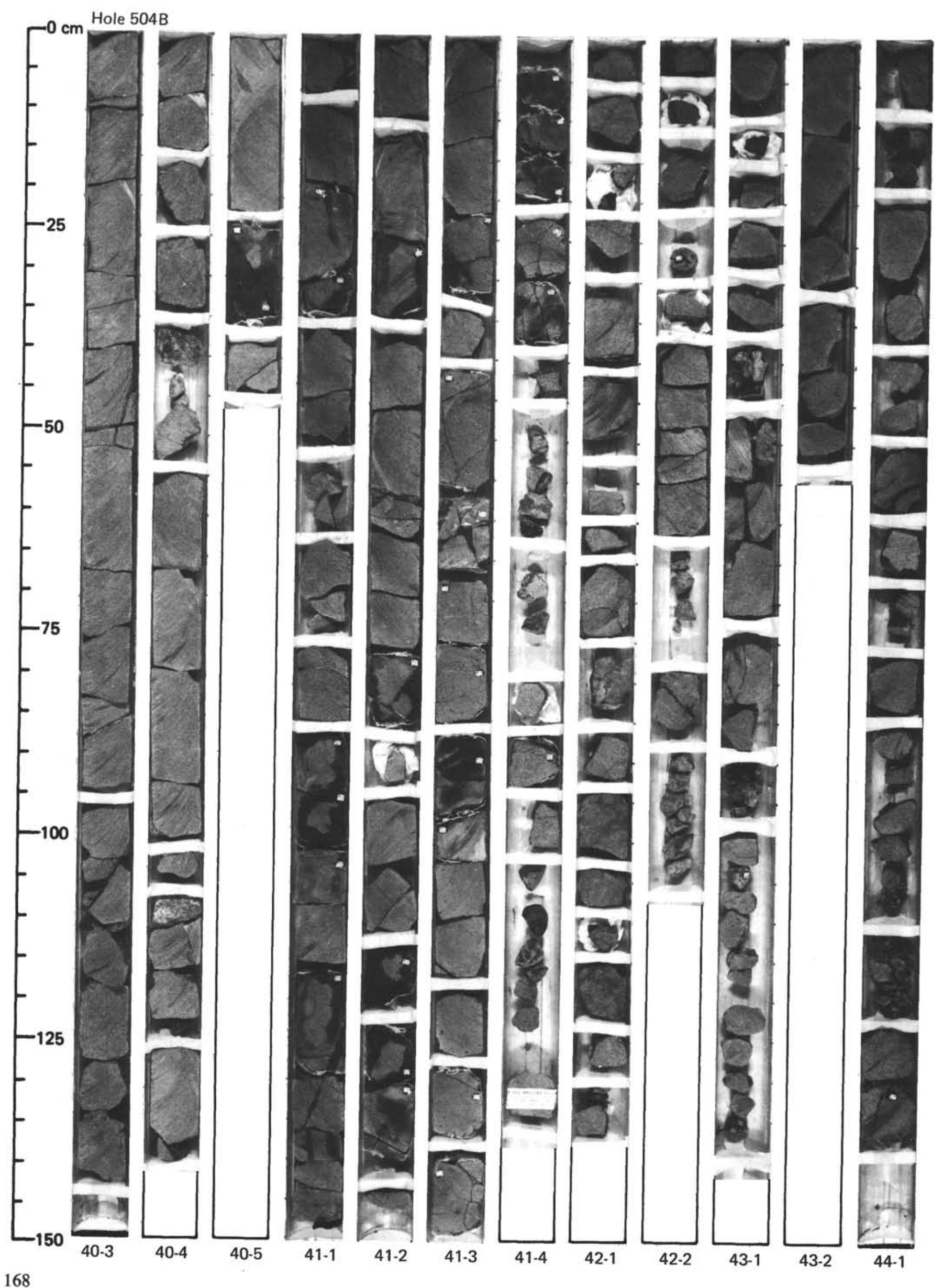




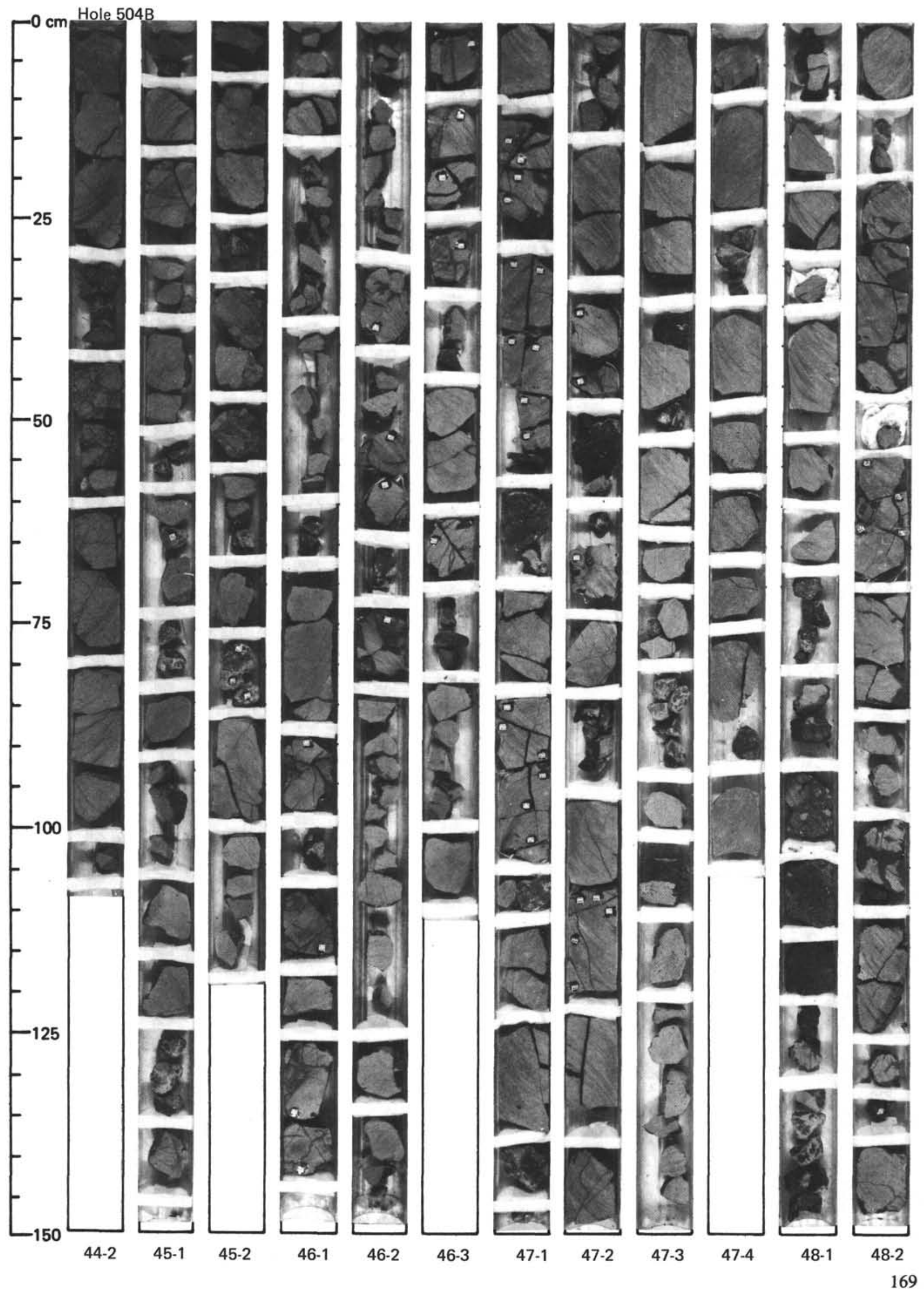




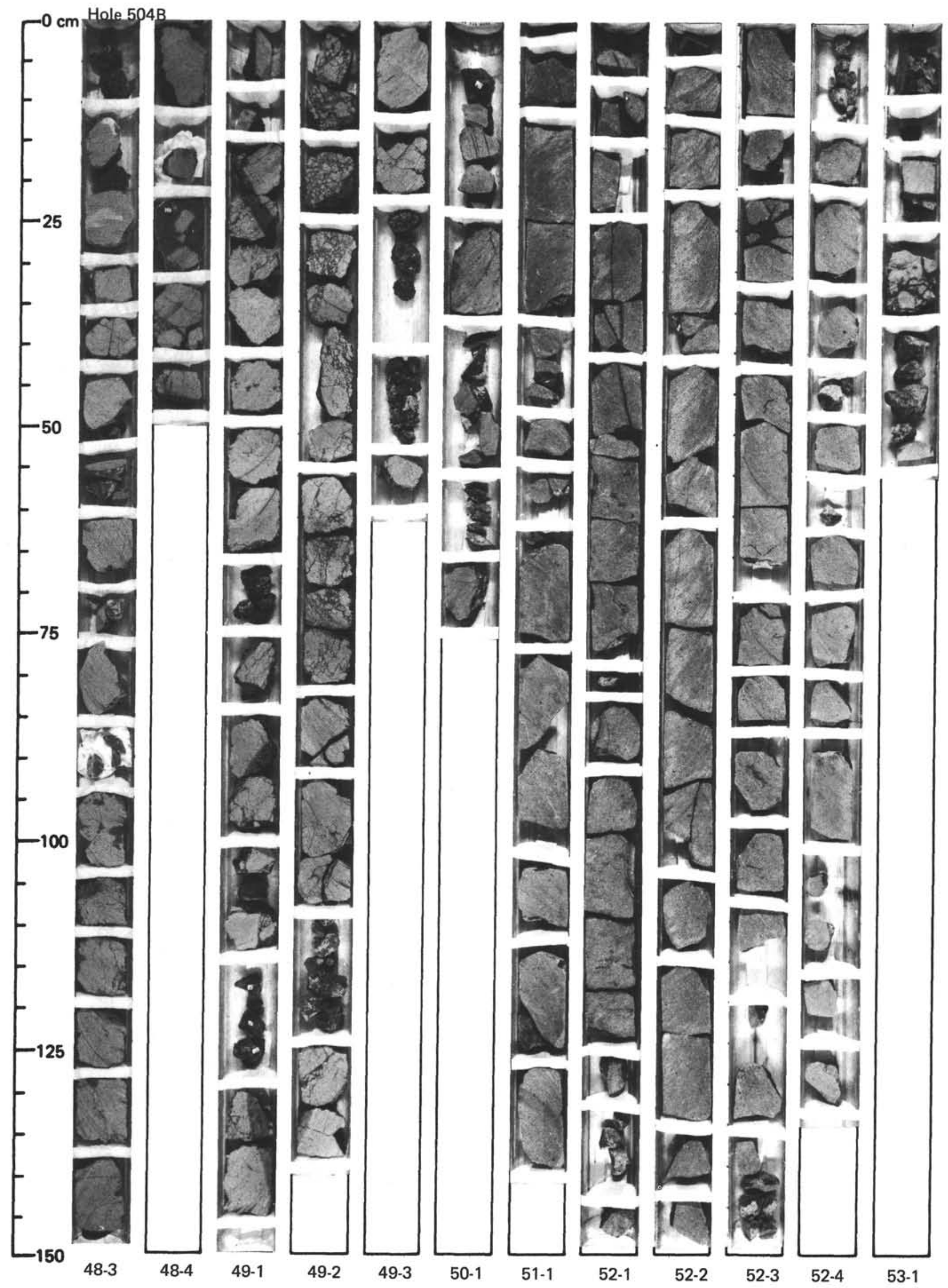




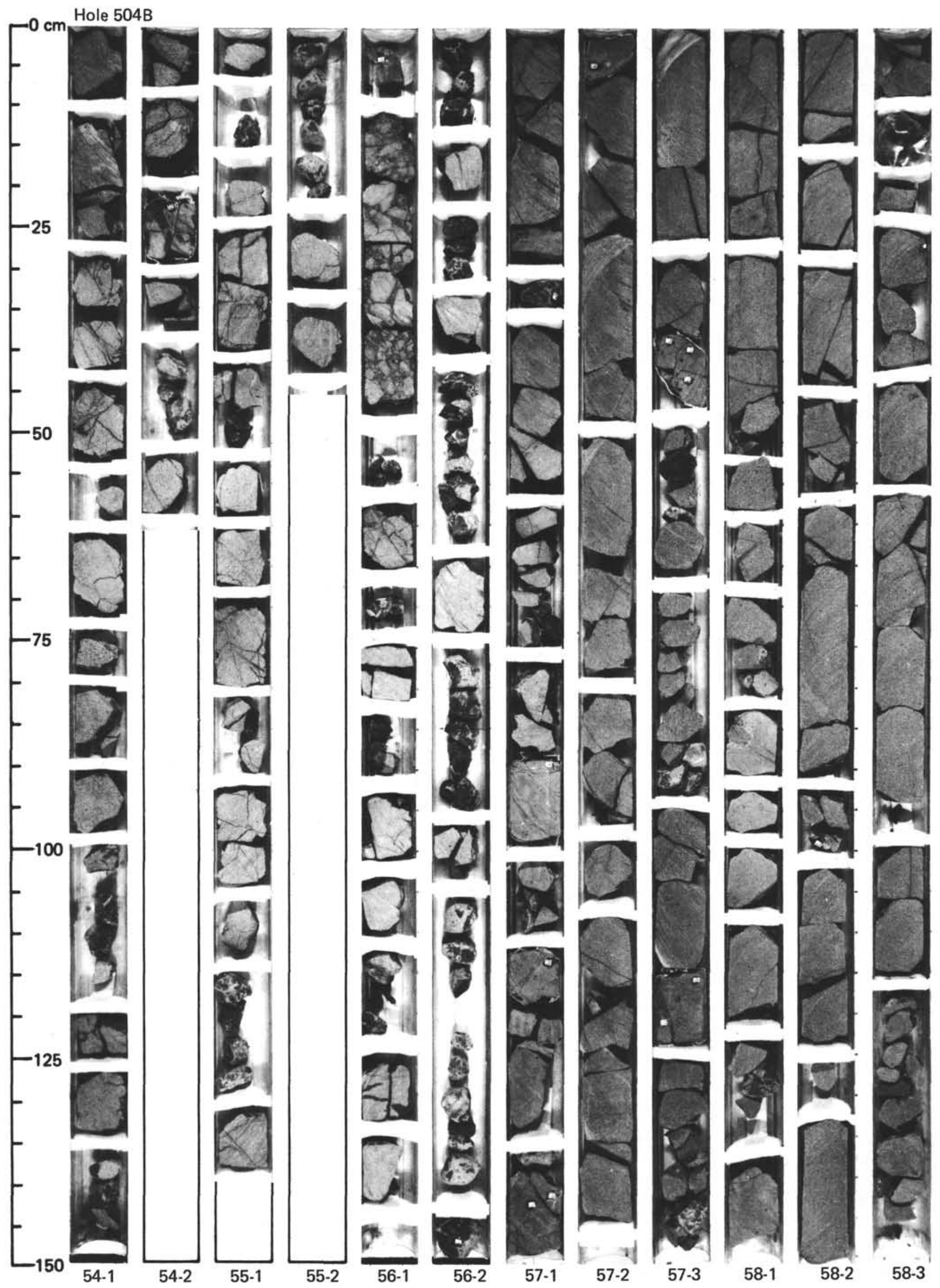




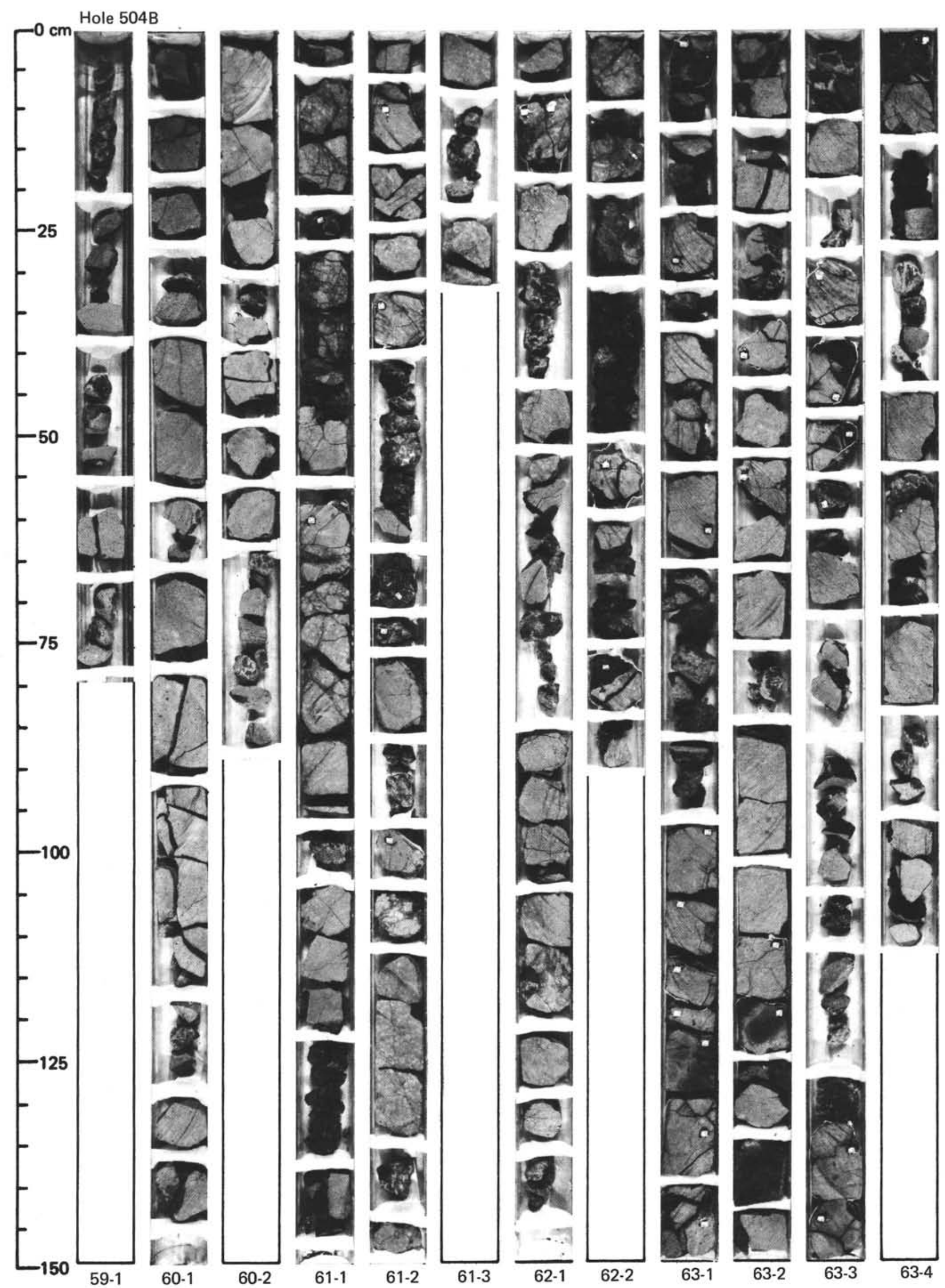




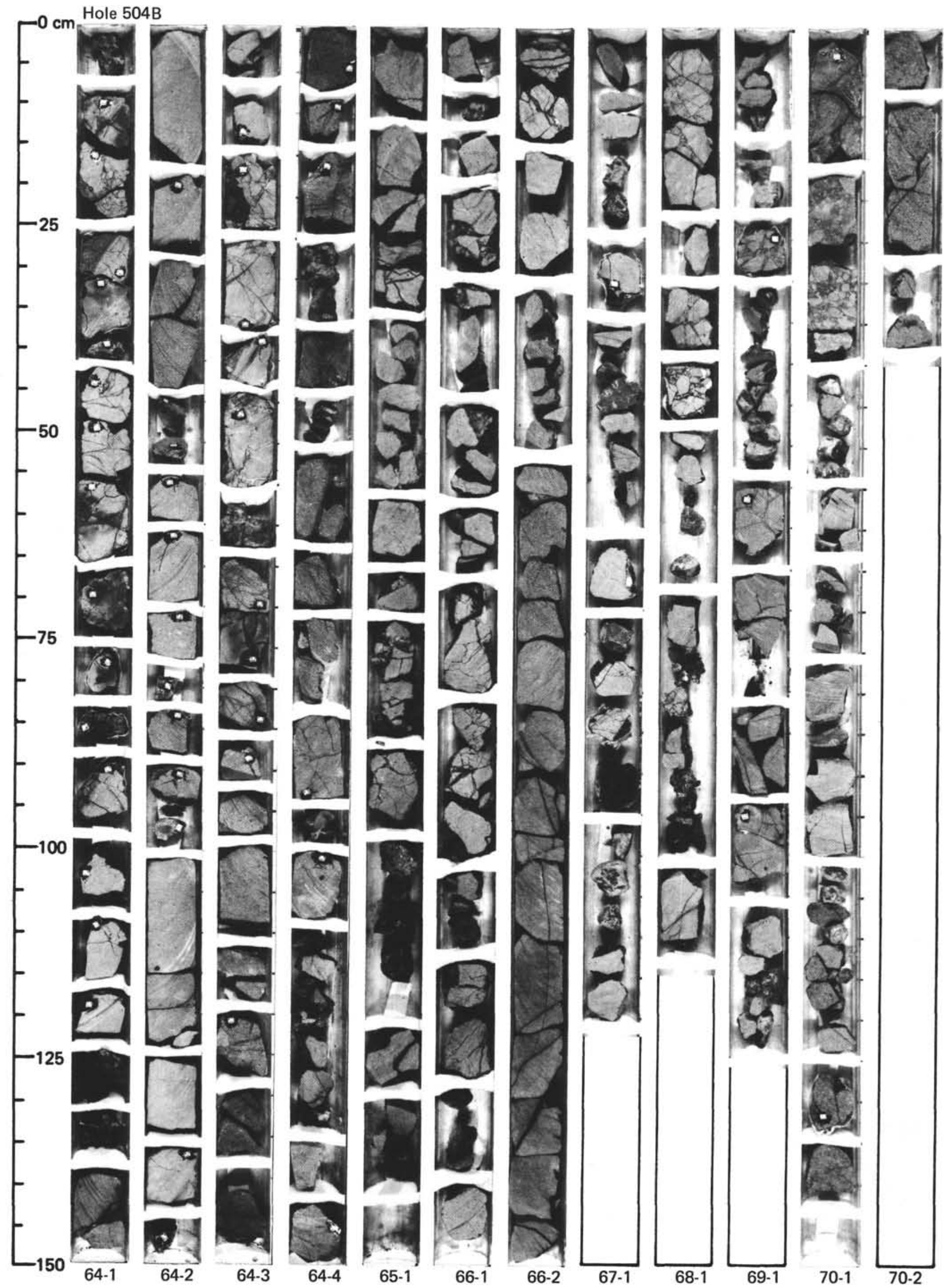

